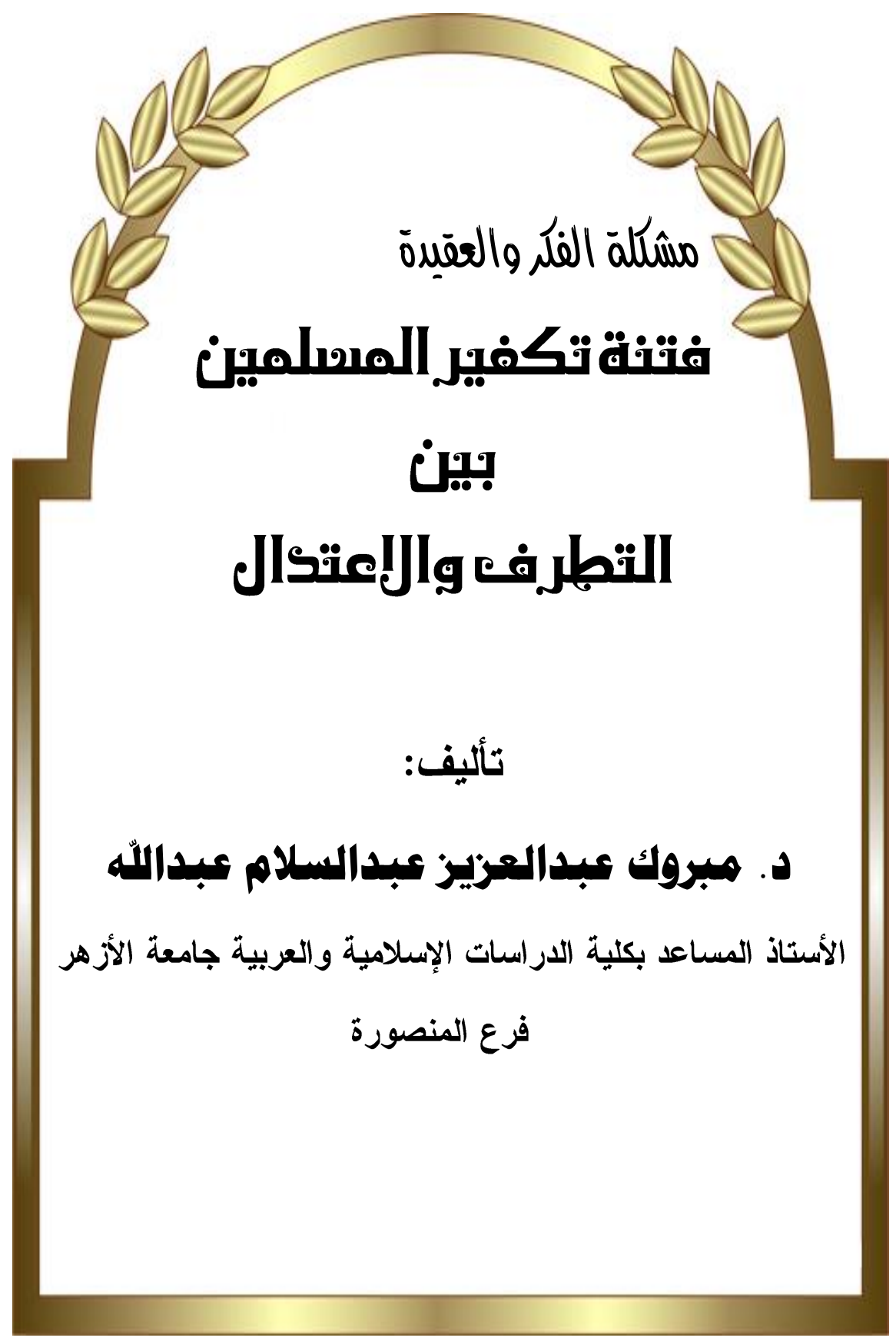




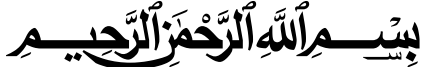

الحمد الله رب العالمين، والصلاة والسلام علـي المبعـوث رحمـة للعالمين وعلى إخوانه وآلـــــهـه وأصحابه أجمعين.

وبـــــ

\section{أهمهيـة المرضوع:}

لابـ من الاعتراف المأساوي بأنتا أمام قضية تكفيـر المســلمين... نتوجه بها إلى شباب الأمة الإسلامية وغيرهم لنؤكد لهم أن المسلم يؤثر

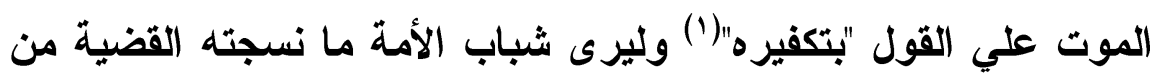

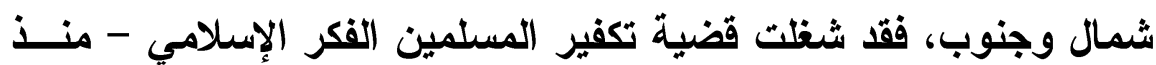

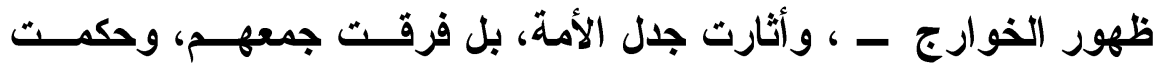
السيف بينهم .

وهي اليوم تزحف إلى عالمنا الايني ، لنري ما خلقته القضية مسن

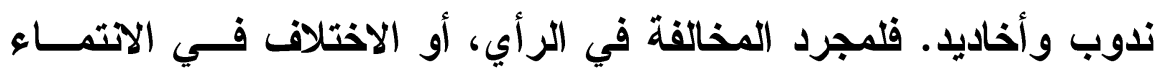
والفكر ، أو الاجتهاد في الفتوي والحكم ، أو المخالفة في الأمر والنهـي

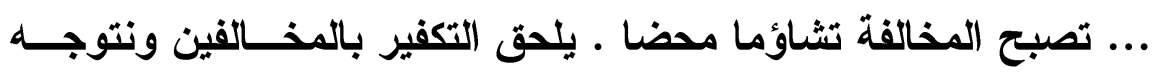
إلى شباب الأمة لنؤكد لهم أن فتنة تكفير المسلمين حسم أمرها علمــاء الصدر الأول الأين تأكد للجميع إخلاصهم للاين ورفضهم النهــــئي للــوم لائم أو عذل عاذل ما فالفكر الإسـلامي عندهم لا يقبـلـل المســاومة. ولا يصيخ إلى هاجس من هنا أو من هناك ـ فمنذ أمد بعيد ، يوم عقدت فرقة

(1) لقوله 
الخوارج "الحروريين"(') أول اجتماع لها بعد خروجهم على الإمام عليكرم الله وجهه ووجه الصحابة أجمعين - بعد أن رضي بـالتحكيم فـي معركة صفين ، وحكموا عليه بالكفر، وحاربوه وأصحابه... حسبنا مسن الأحداث أنها خلفت لنا فرقتي الخوارج و الشيعة.

ألسنا مطالبين بقراعة قضية تكفير المسلمين علي هذا النحو الــــي قصد فيه علماء الأمـة بيان حكم تكفير المسلمين علــي الإطــلاق ؟ دون ربطها بأحداث الخلافة بين "علي" و "معاوية" رضي الله عنهما . ومع علمنا بأن شباب الأمة يثق وينقاد لرأى علماء الاين في الصدر

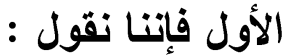

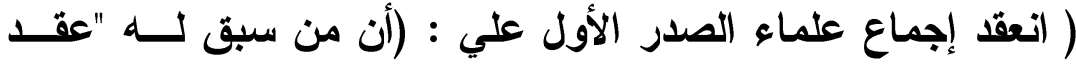
الإسلام " بيقين، لا يجوز إخراجه منه إلا بيقين مثله، فإن اليقين لا يزول

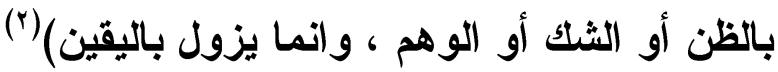
ومعلوم أنه لا يخرجك من الإيمان إلا ما أدخلك فيه

و هكذا يتبدى حس القبض علي قضية تثير اهتمام الأمة ، وتسترعي

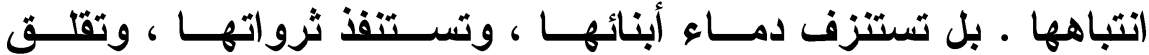
مضاجعها. حكاما ومحكومين وهنا نتساعل : ما قول الأين حكموا علـي الأمة بالمروق من الاين ، والخروج عن الإسلام لمجرد المخالفــة فــي الرأي ، أو الفكر ، أو الاجتهاد ، أو ... الخ . ماذا تقولون عن حــيث

$$
\text { (1) نسبة إلي بلدة "حروراء" بقرب الكوفة }
$$

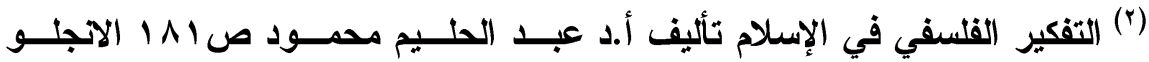




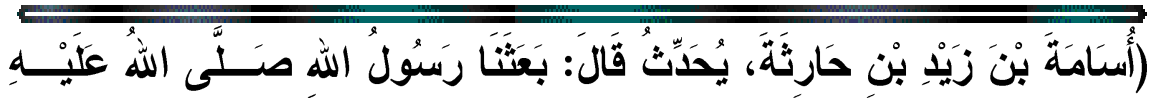

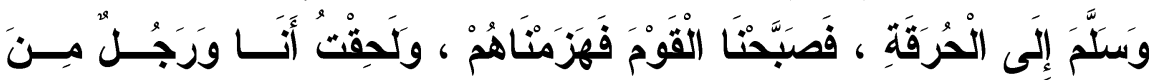

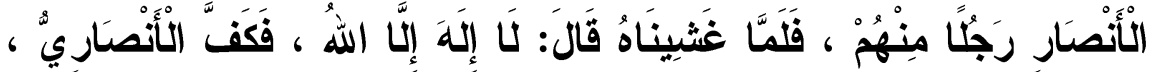

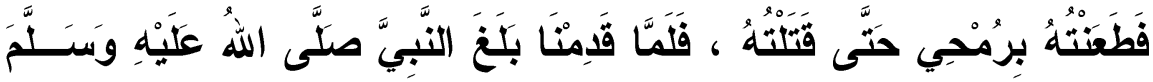

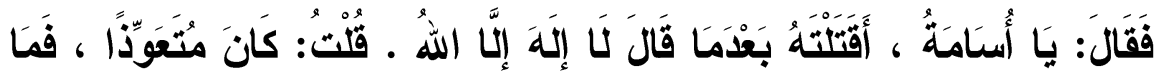

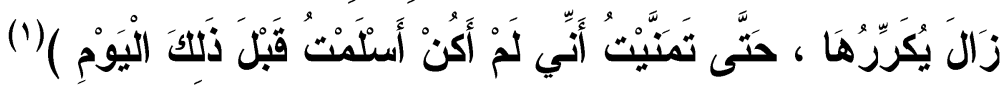

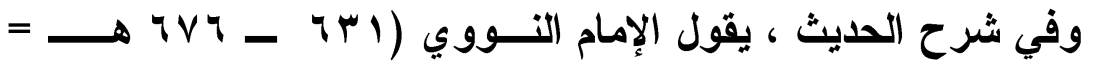

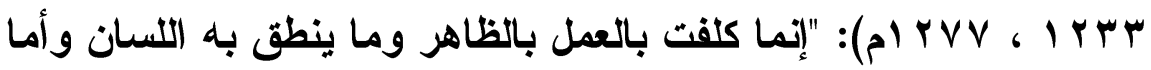
القلب فليس لأك طريق إلى معرفة ما فيه )(r)

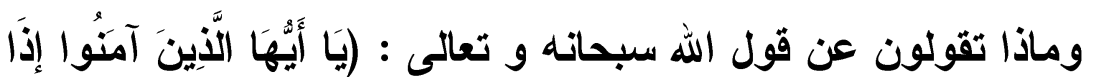

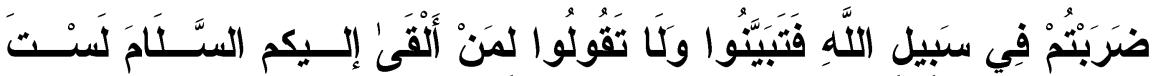

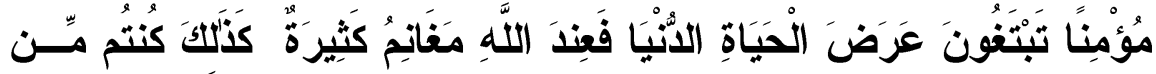

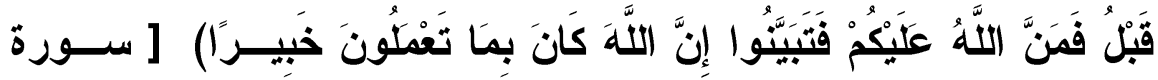
] النساء آية ع

(1) أخرجه البخاري في "صحيحه" ( كتاب المغازي ، باب بعث التبي صلى الله عليــه

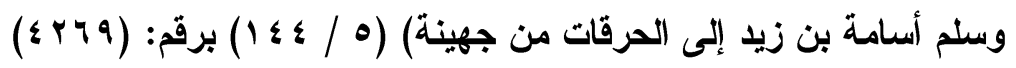
(r) الأربعون النووية ـ تأليف: أبو زكريا محيي الدين يحيى بن شرف النــووي. جr صـ • 1 . عُنِيَ بِهِ: قصي محمد نورس الحلاق، وأنور بن أبي بكـر الثــيخي.

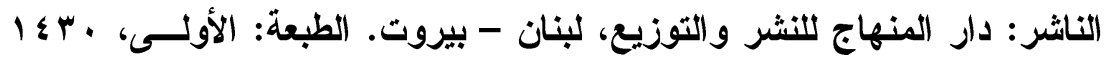
- م 


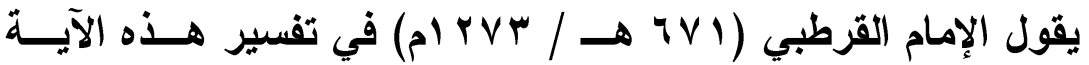
الكريمة : "إن في هذا التوجيه الإههي من الفقه باب عظـيم ، وهـــو أن الأحكام تناط بالمظان والظواهر ، لا علي القطع واطلاع السرائر فالله لم يجعل لعباده غير الحكم بالظاهر)(') ولقد استطاعت هذه الأدلة وغيرها كثير أن تعبئ كل عقول علمـاء

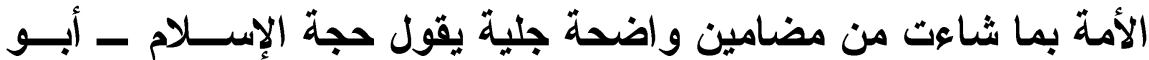

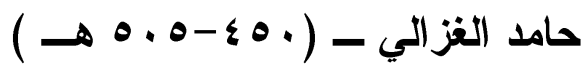

(إنه لا يسارع إلى التكفير إلا الجهلة ... وينبغي الاحتراز من التكفير

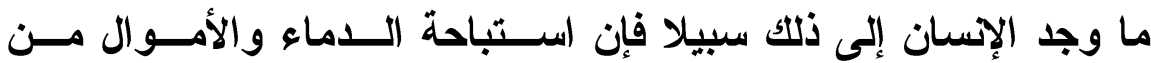
المصليين إلى القبلة. المصرحين بقول : لا إله إلا الله محمد رسول الله. خطأ والخطأ في ترك ألف كافر أهون من الخطأ في سفك محجمة من دم

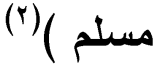

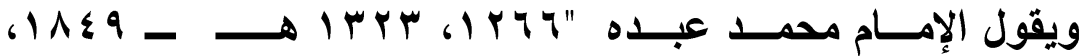
ه. 9 ام" : (إن الله لـ يجعل للخليفة ... ولا القاضي ... ولا للمفتي... ولا لشيخ الإسلام أدنى سلطة علي العقائد وتقرير الأحكام ... ولا يسوغ لواحد منهم أن يلدعى حق السيطرة علي إيمان أحد أو عبادته لربــهـه ، أو ينازعه طريق نظره ... - ل

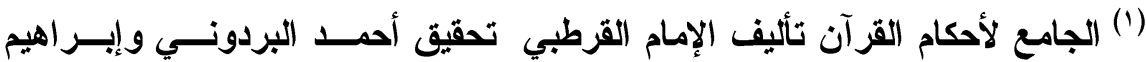

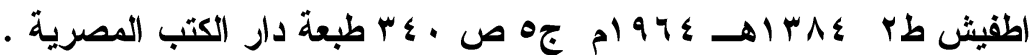

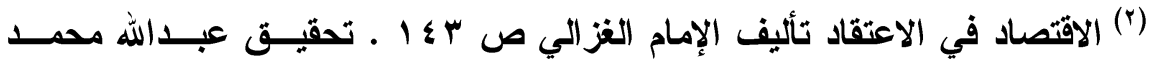

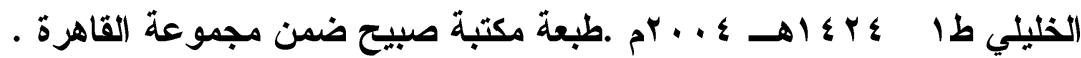


فليس في الإسلام سلطة دينية سوى ســلطة الموعظــة الحســنة ،

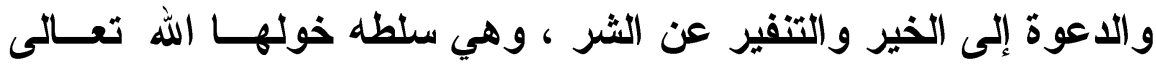

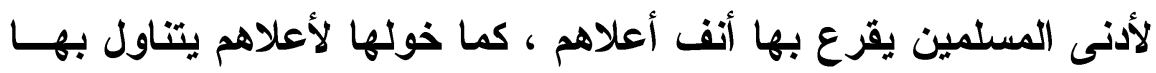

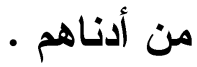
وليس لمسلم ، مهما علا كعبه في الإسلام، علي آخر، مهما انحطت منزلته فيه ، إلا حق النصيحة والإششاد ... ولقد اثتهر بين المســلمين وعُرف من قواعد أحكام دينهم أنه إذا صدر قول من قائل يحتمل الكفــر

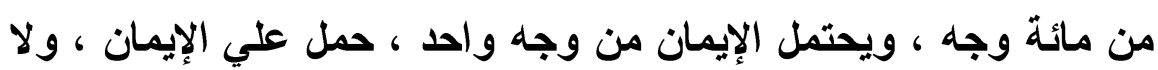

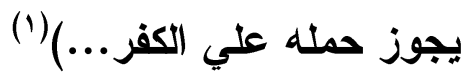
يؤكد مضمون هذه المقولة الأخيرة للإمام محمد عبده ما نــراه مــن خطورة إلحاق التكفير بالأمة آحادا أو جماعات

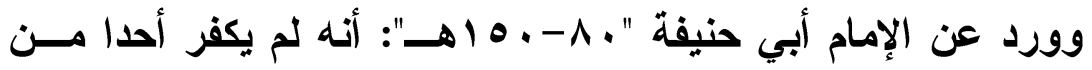

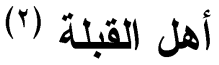

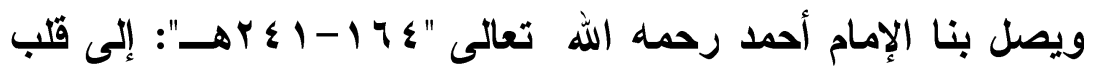
القضية بلا مزايدات في قوله لمن امتحنوه في محنة خلق القرآن الكريم

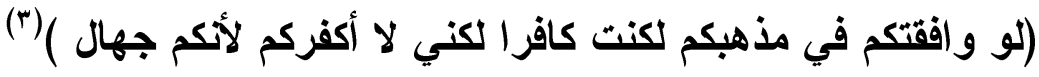

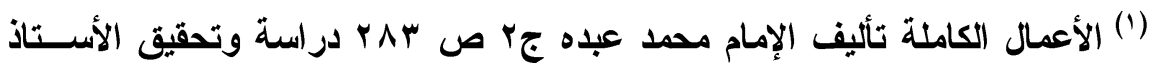

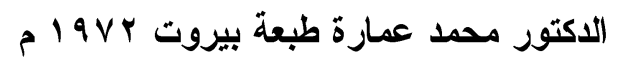

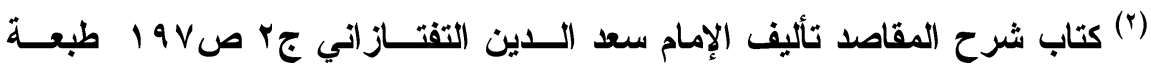

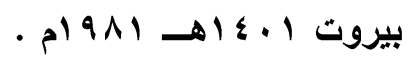

(") التكفير قليما وحديثا . تأليف الاكتور نعــان الســاهر صهب طبعـة القـاهرة 


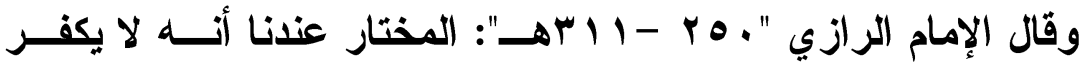

أحد من أهل القبلة إلا بليل منفصل (1)

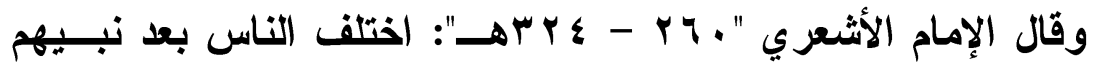

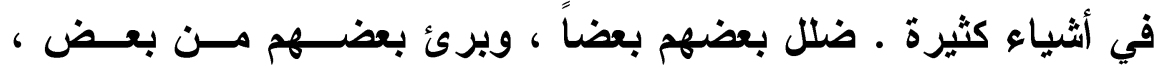

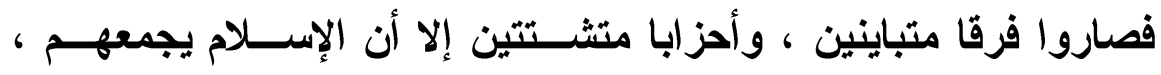

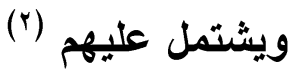

وإذا كان علماء الأمة الإسلامية الذين ولّاوا علي كتاب ربهم وســنة

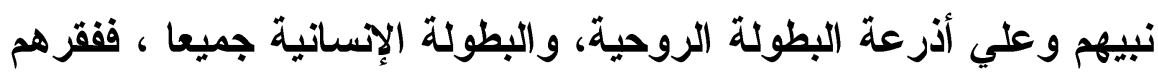
عف، وغناهم مشترك، وحاجاتهم مكفوفة، ومالهم مبذول، وشـــاعتهم لنصرة دين الله معروفة، واندفاعهم لقول الحق مضمون وإخلاصهم لاين ربهم لا يقبل المساومة روي عنهم أنهم لم يكفروا أحدا من أهل القبلة. ولقد أعطي هؤلاء العلماء قضية التكفير حجمها الحقيقي. ونتســاءل

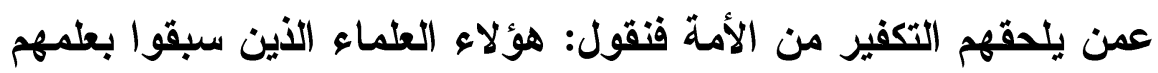

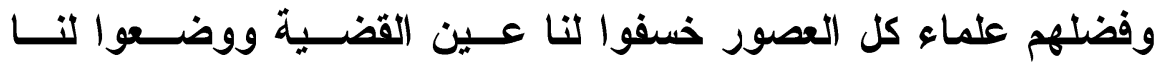
الضوابط الضرورية لإحاق الكفر الأي نتوقاه نحن في أحكامنا وإن فعلته هذه الفئة المؤمنة التي أضاعت شمعة قبل أن تلعن الظلام ـ التكفير ـ

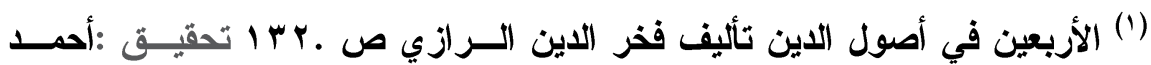

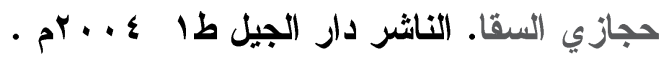
(†) مقالات الإسلاميين واختلاف المصلين جا ص ع ب تأليف الأثعري عنى بتصحيحه

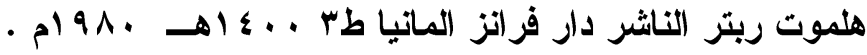


وإذن فمناط التفريق بين القول بالإيمان أو التكفير يروق لنا أخذه من علماء الأمة الموثوق بطلمه وعملهم ـ لأننا عيال عليهم ـ ولولا هؤلاء العلماء لذهب الجهلاء بثلث الأمة ــ أو يزيد - إلى الكفر .

\section{أسباب اختيار الموضوع : (أل}

أولا : هناك في عالمنا المعاصر ظاهرة توقف عندها الفكر طــويلا ،

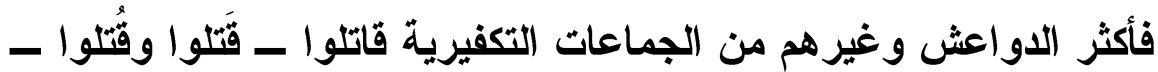

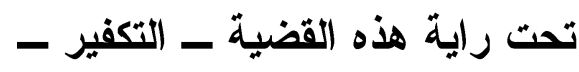

ثانيـا : قضية التكفير لم تقف عند حد الاقتناع العقلي بها بل تخطت هذه المرحلة إلى عقيدة راسخة محلها القلب .

ثالثـا : يمكن النظر إلى القضية من وجهة إيمانية نتأمل المفردات ،

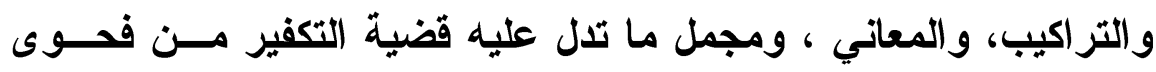

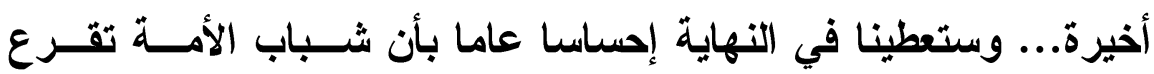
أسماعهم لفظة التكفير لا لفظة الإيمان:

(فالأشثاعرة و السلفية يكفرون المعتزلة بزعم أنهم كذبوا فــي عـدم إثبات صفات العلم والقدرة... وقولهم بخلق القرآن الكــريم، وإنكـــارهم

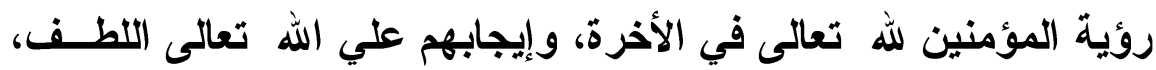

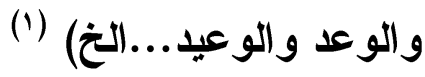

(1) انظر المقاصد تأليف التفتاز اني - سعد الدين مسعود بـن عمسر بـن عبــــ الله

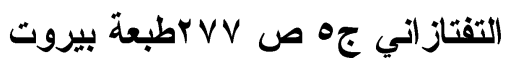


وتقبض المعتزلة علي ( تكفير الأثاعرة ، بحجة أنهم يقولون بوجود قدماء مشاركين لله تعالى في صفة القدم فإذا كان النصارى كفروا بثلاثة

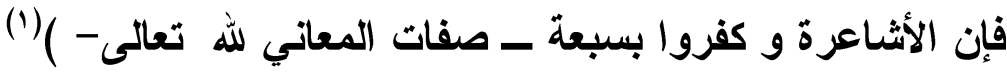
( ويكفر الحنابلة ، والأشتعرية وغيرهم من الفقهاء وأهل الحــديث ، الفلاسفة لقولهم بقدم العالم ، وإنكارهم علم الله بالجزئيات ، وإنكار حشر

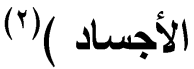

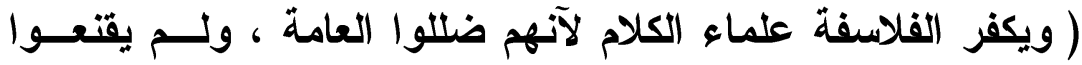
الخاصة ووقفوا في وسط الطريث مـع الجدل الأي لا يهبط إلــى طريـث الإقناع ، ولا يرتقى ، وأفسدوا العامة بتأويلاتهم الفاسدة ، ومن يفعل ذلتك

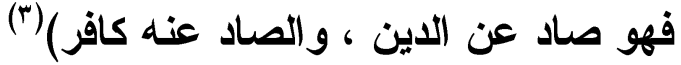

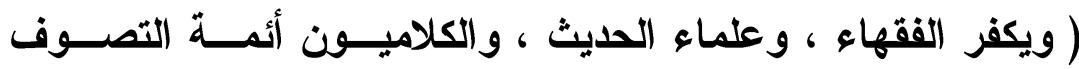
لقولهم بالظاهر والبــاطن ، وبالقتــاء و العلــول والاتحــاد ، ووحـــة

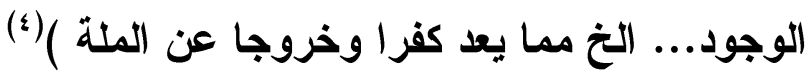

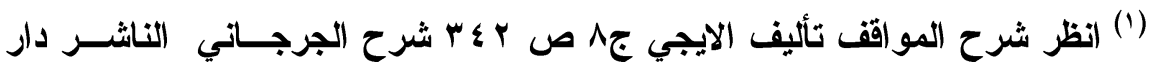

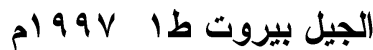

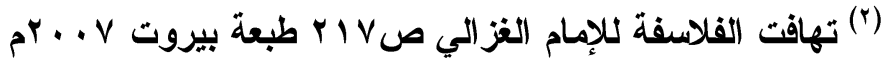

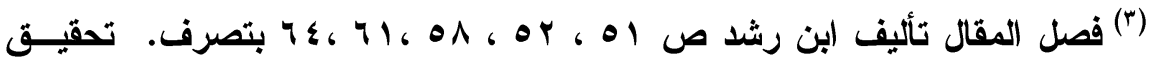

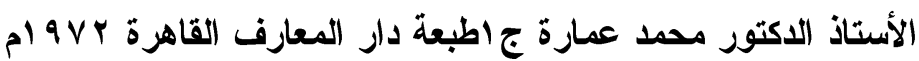

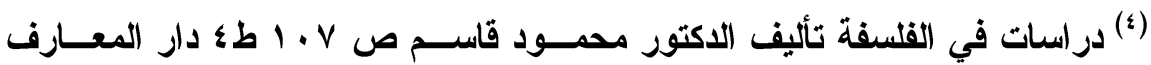


بل ربما كفر أصحاب الفريق الواحل بعضه بعضا كما فعـل الثــيعة

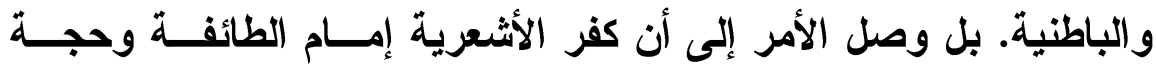

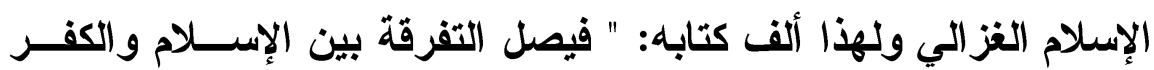

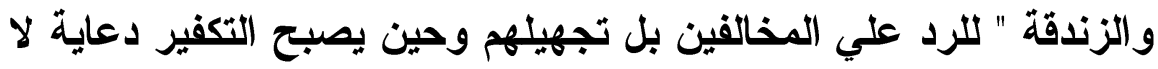

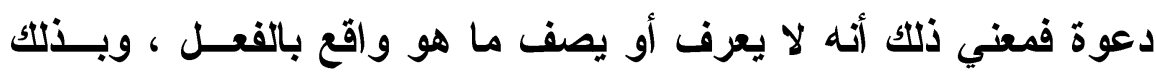

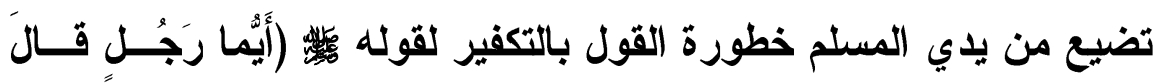

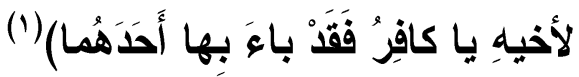

رابعا : إن الفكر الحقيقي هو الذي ينطلق (من) الموضــوع ولــيس (إلى) الموضوع • وهذا هو الفرق.

فالذين ينطلقون من الموضوع أصحاب قضــية إيمانيــة وصـاحب

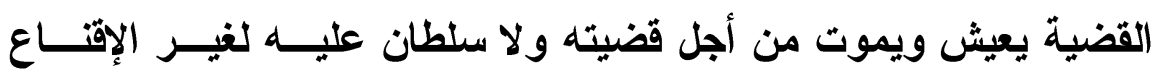

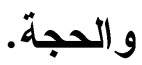

وميع الحجة والإقتاع يستجيب للحق إذا تبين ولا ينأى عن الحــق إذا

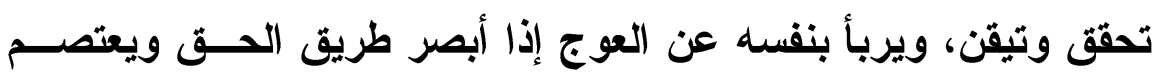

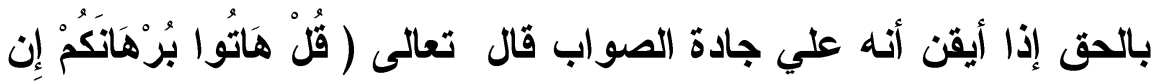

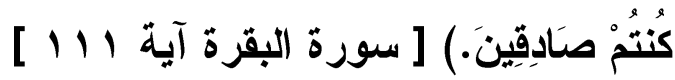
هذا الفريق عنيد قوي لأن القضية عنده إيمانية. ولسنا نري لهذا الاتجاه من سبيل سوى دور العلماء .

(1) أخرجه البخاري في "صحيحه"( كتاب الأدب ، باب من كفر أخاه بغير تأويل فهـو

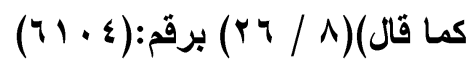


أما الفريق الآخر الأي انطلق إلى الموضوع : فقضيته ادعائية ، كما أنه لا يمكن أن يثبت أمام القوة المسلحة لأنه ليس حامل لهمــوم دينــهـ بقدر ما هو حاملا لهموم دنياه فالقضية عنده هامشية علي متن مكاسب

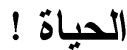

هذا الفريق ترعبه القوة المسلحة تزلزل الأرض من تحت قدميـه ؛ لأنه غاضب لهوي نفسي أو دنيوي أو سياسي ... وحس العاطفة الدينية

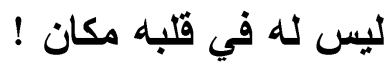

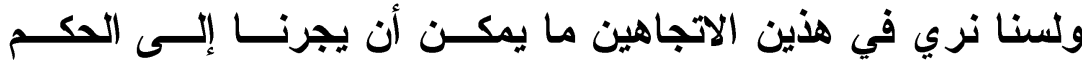
المتسرع باستعمال القوة مـع الجميع لأسهما نقيضان لا يلتقيان وأصحاب الفكر الأين تقنعهم الحجة سيقاتلون بالفكر والحيلة والمكر و الاهاء والخديعة إذا وهنت قوتهم أو ضعفت حيلتهم وسيتحالفون مــع الثيطان ويستعينون بخصوم الاين والوطن ومن ثم تثثــكل الجماعــات والجمعيات السريـة ـ التي تخطط في الظلام وتعاني منهـــا الأمــة علــي الاوام ألم أقل لك بأن القضية ــ التكفير ــ أعقد من أن نتشــرع بــرأي فيها .

خامسسا : هذه المقابلة المأساوية بين الأمة وشبابها فجرتها عوامل عديدة من أهمها غياب الدين عن مدارسنا وجامعاتنا. وجعل مادة الــدين لا تضاف إلى المجموع بحجة إخوانتا النصارى مع العلم بــأن الأخــلاق التي دعا إليها المسيح تثتق وروح النصوص الثرعية وروح المأســاة في غياب المفاهيم الصحيحة لأبناء الأمة مسؤولية المفكرين. 
وليت يحرص مفكري الامة علي سلامتها وعلى أن يقولوا فكرا يرقى بالآمة وليس مجرد مقولات

سادسا: أعتقد أن الرعيل السابق من المفكرين كان تفوقهم الأسساسي

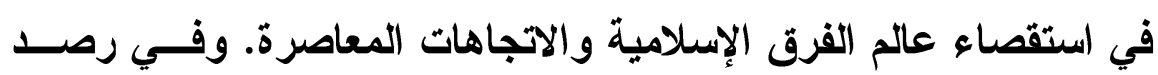

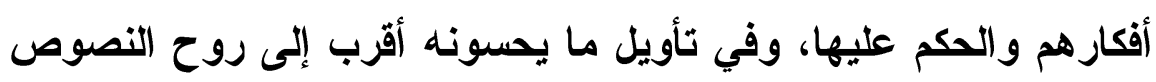

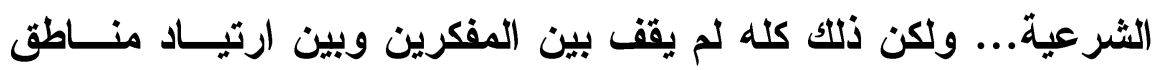
الأسس التي ينبني عليها الحكم بالتكفير وبحثنا محاولة لإثبات اقتــــارنا على وضع قو اعد عامة للقضية لنحكم وفي أيدينا الميزان. سابعا: ومهما يكن من شيء فقد ظل الجانب الإيماني علي قوته في

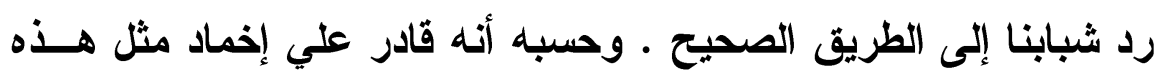

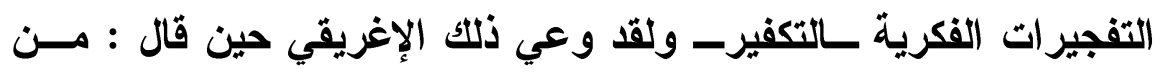

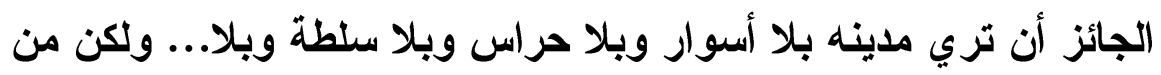

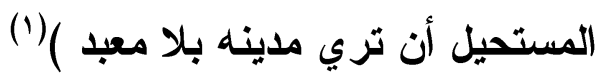

\section{هنهجنا في البحث}

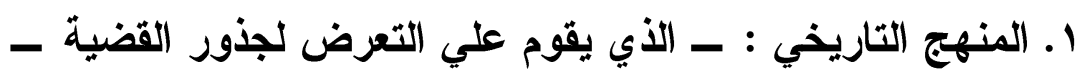

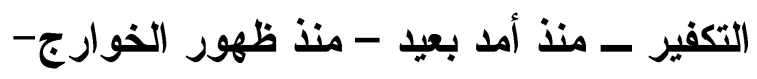

r. المنهج التحليلي: الذي يهدف إلى تحليل الفكر الإســلامي فئسي

قضية التكفير

r. المنهج التعليلي : الذي يهذف إلى التعليل بعد التحليل .

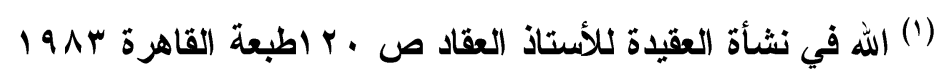


ع. المنهج المقارن : إذ عمدت إلى مقارنة الفكـر الـــيل بــالفكر الإسلامي في مواطن عديدة من البحث هـ المنهج النقضي : الأي يقوم علي هدم الفكر المخــالف للكتــاب والسنة 7. المنهج الاستنباطي : الأي يعتمد علــي اسـتنباط التتــائج مــن المقدمات

لم يبق إلا أن نقول : رمز إلى ما حدث ، ونوحي بما كان ، ونجسد ما وقع من خلال : مقدمة وثثلاث قضايا متثابكة وخاتمة

الإقدهة: تناولنا فيها أهمية الموضوع ، وأسباب اختياره ، وقيمتـهـ الفكرية، ومنهجنا في البحث . المألة الأولى : أسباب ومظاهر فتنة الغلو والتكفير • وكانت القضية خاصة بمنشأ الأسباب والظواهر التي على أساســها نشأة فتنة التكفير ف ن المسألة الثانية : الإسلام ، والإيمان ، والكفر .

وهذه القضية خاصة بالمشكثة الأساسية التي على أساســـها كـان البحث ـ تناولت فيها معنى الإسلام ، والإيمان ، والكفر ـ مركزا حــديثي

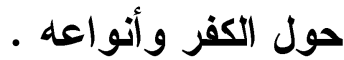

المسألة الثالثـة : في قضية التكفير مسائل يجب أن تفهم ومفــاهيم يجب أن توضح. 
مجلة كلية الكراسعات الإسلإمية والعريبة بنات بنهي لصويف العذد العاشر.

تعرضت في هذه القضية لمسائل عديــدة تتصـل بقضــية التكفيـر ووضحت في جلاء خطورة الفهم الخاطئ لهذه المسائل .

الخاتمة : كاتت وقفة قصيرة أوضحنا من خلالها أهم النتائج وأهمية القضية في عالمنا المعاصر وجناية التكفيـر وخطرهـــا علــى الإســلام

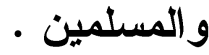

والله أسأل أن يحرك موضوع البحث جو التفكير باتكائه على قضــايا و مسائل ثثري الفكر وتوجهه وتصححه، فيكسر بــنلك رتابــة التقريــر والقول

وعليه الله قصد السببيل إنه سميع قرييب مجيبب. 


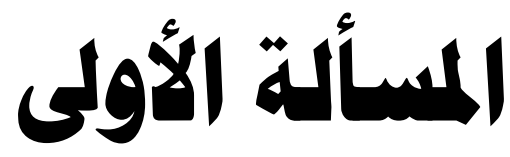

أسباب فتنة الغلووالتكفير

وتشتمل هذه المسألة علي ما يأتي :

ا - المسلمون من الوحدة إلى التفرق

r r - r أسباب الغلو والتكفير

r- ب - مظاهر الغلو والتكفير 


\section{هن الوحدة إلى التفرق}

المهاجرون والأصسار لاتت قلوبهم لكتاب ربهم وسنة نبيهم فـأحبوا

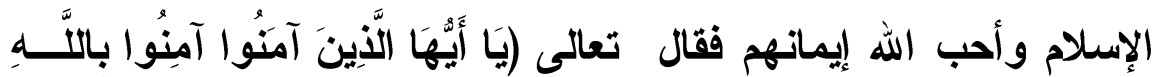

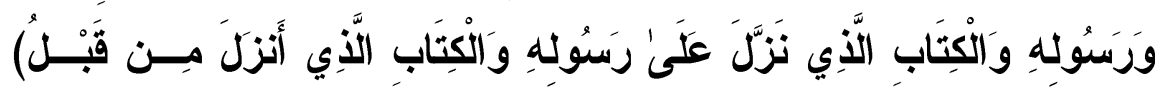

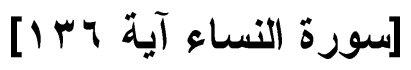

والمعني : أن القرآن الكريم مدح إيمانهم بل طالبهم بالبقــاء عليـــه

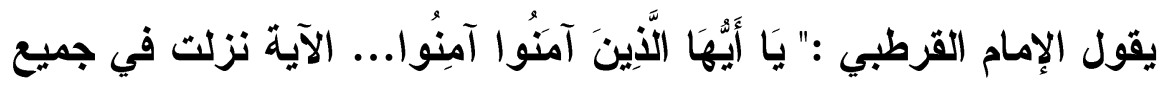
المؤمنين والمعنى : يا أيها الأين صدقوا أقيموا على تصديقكم واثبتــوا

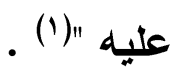

فالمسلمون أمة واحدة ... قرر ذلك قر آنهم الكريم الذي يعد الــبلاغ الإههي الأي يحفظونه في الصدور والسطور ، ويقدسونه ... ويتلونه في صلواتهم آناء الليل وأطراف النهار

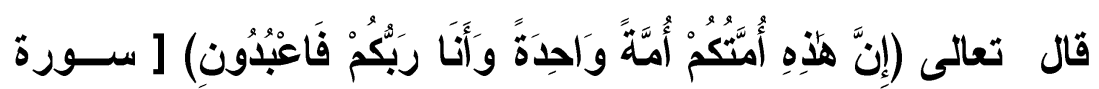
الأببياء آية r a

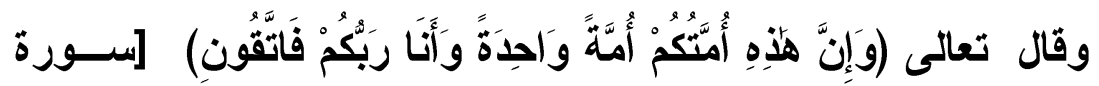
[المؤمنون آية

ونعتقد أن وحدة الأمة في لحظات الإحســاس بقـــة العــد والعــدة وغروب كل شيء دنيوي •

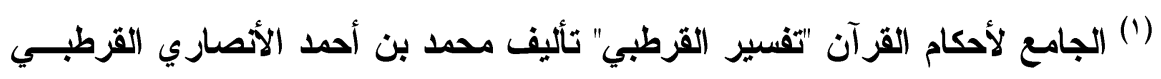

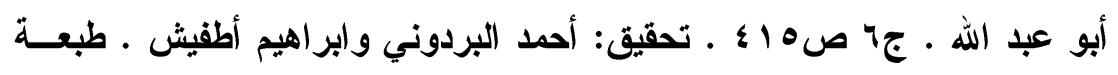

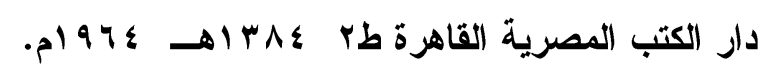




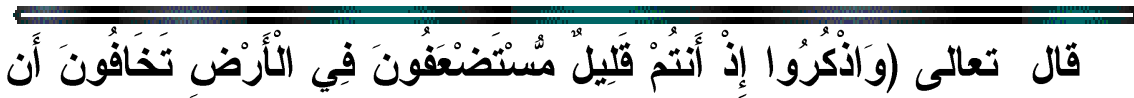

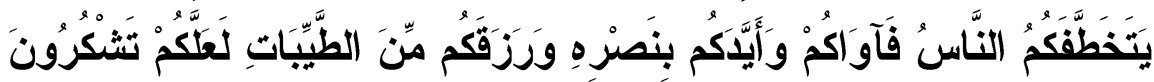

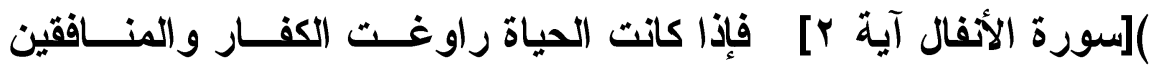
وخاتلت فيهم قوتهم وحبهم الجارف للانيا ، فإن القـــرآن الكــــيم يــلـي بنصره للمؤمنين قبل أن تنتهي فصول هذه الحياة المأسـاة التي عاثـــها الكفار والمنافقون ويؤكد أن المؤمنين نقبوا عن فحوي الحياة وجــدواها بلا هوادة فوجدوا أن وحدتهم إرادة إلهية ومشيئة ربانية قـال تعـالى

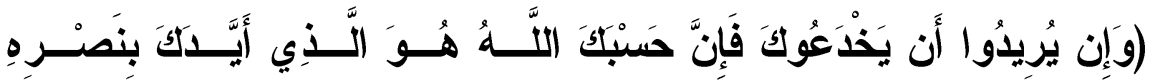

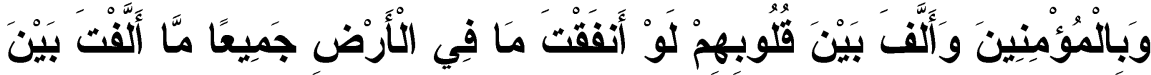

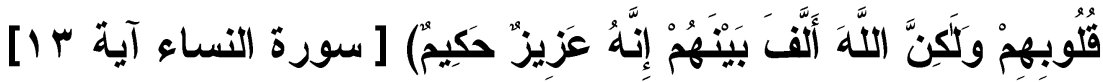
إن تجسيد القرآن الكريم عشث الصحابة لكتاب ربهم وسنة نبـيهم ، وتجسيد معاناتهم البطولية في البحث عن حرية الاعتقاد يعطي للصحابة إمكان أن تكون حياتهم الانيوية محاذية لتعاليم ربهم وسنة نبــيهم قـال

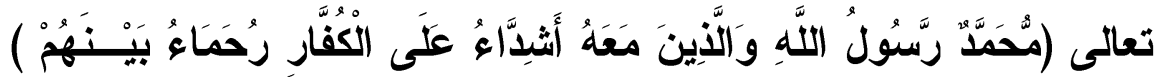

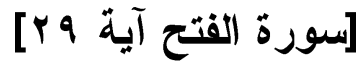

وتاريخ هذه الأمة الإسلامية شاهد صدق ودليل حق ، أنها خاضـــ

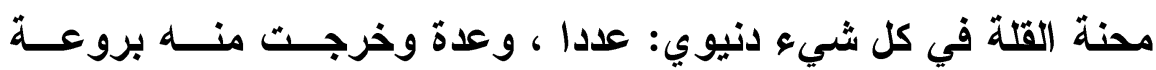
الأصهار الإيماني الأي قهر قوي الفرس والروم فقتحت الأمة الإسلامية في ثمانين عاما بالدين الإسلامي أرضا وعلما أوسع مما فتح الرومان في ثمانية قرون ! وتبني بوحدتها الوسطية الإسلامية أعظم حضــارة فـي

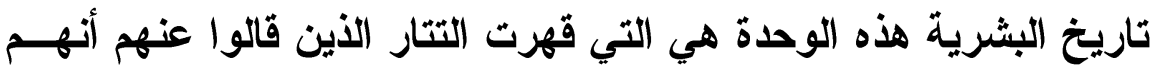


بلغوا في الانيا غايات لا يبلغها سواهم ، وقهروا الصليبين الذين ظنوا أن قوتهم التي سيطرت قرنين من الزمان لن تقهر.

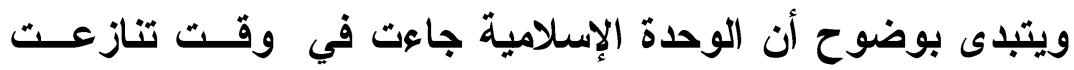
البشرية فيه آلهة متعددة ، ومعبودات متفرقة ، فكان أول مقاصد الرسالة التهادية الاخيرة إبطال عقيدة الثرك والوثنية ، وإرساء عقيدة التوحيد الإلهيـة.

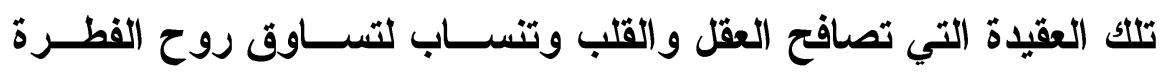

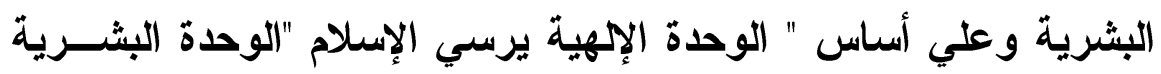

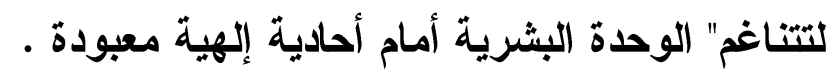

وفطن المسلمون أن لهذه الوحدة قائدا يسوســها ويـدبر شــونها

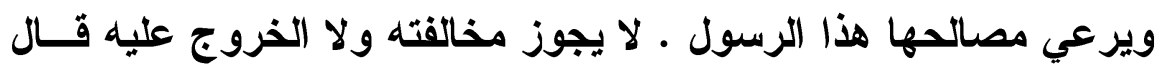

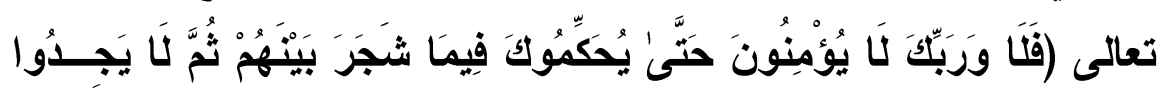

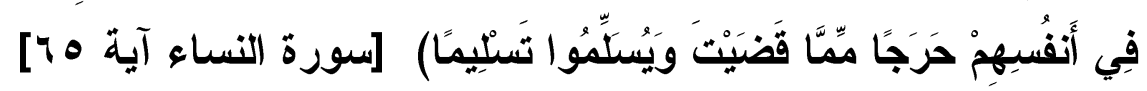
وتدور الوحدة الإسلامية في ثلاث وحدات متناغمة: أولا: الوحدة الاينية ثانيا: الوحدة الاجتماعية ثاثا: الوحدة السياسية وقبل أن نبدأ في توضيح هذه الوحدات نقــول: إن أعظــم مبــادئ الإسلام، وأسمي مقاصده 


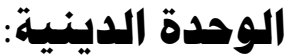

قد عُرف من آيات القرآن الكريم أن الدين الذي ارتضاه الله للنــساس

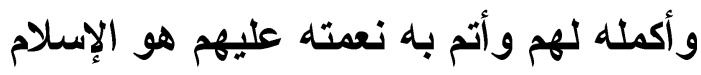

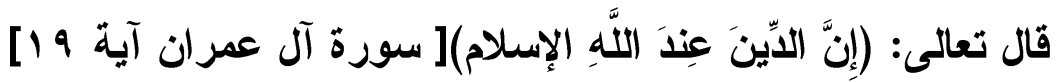

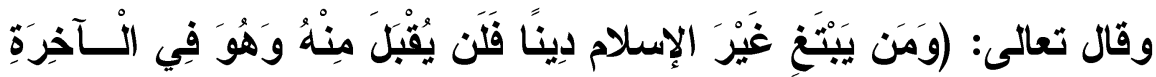

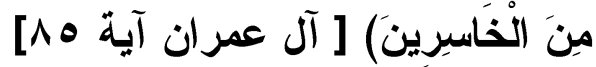

وإذن فالإسلام بمعناه العام: هو دعوة جميع الأبيـاء والمرسـلين.

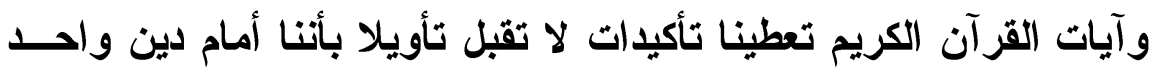
هو الإسلام أرسل الله تعالى به جميع رسله ، فنوح عليه السلام يقــول

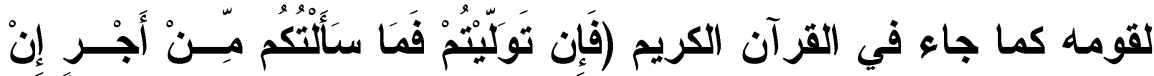

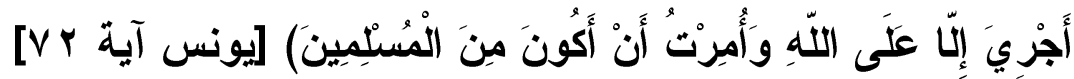

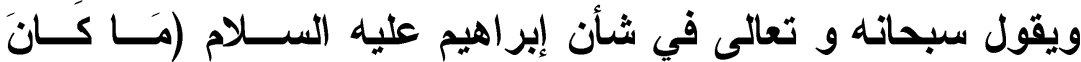

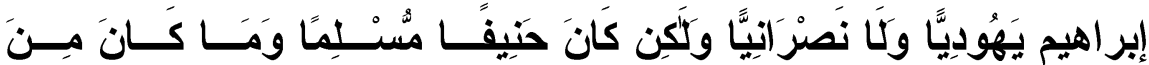

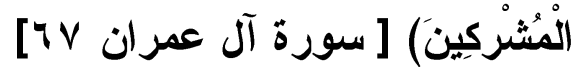

ويقول سبحانه و تعالى في شأن إبراهيم ويعقوب عليهـــا الســلام

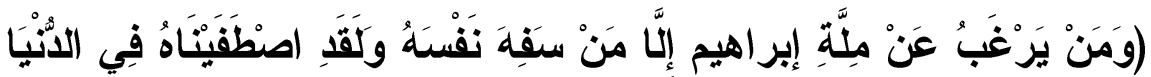

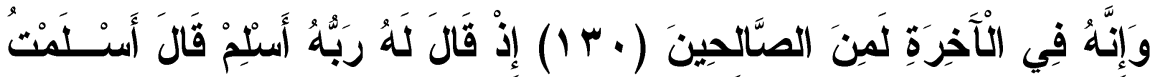

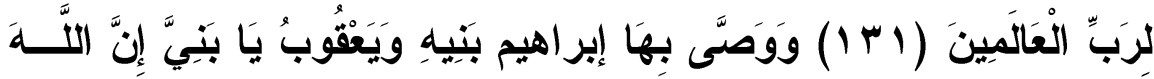

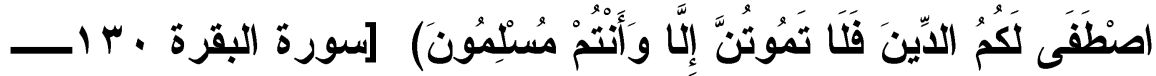
[ITr 


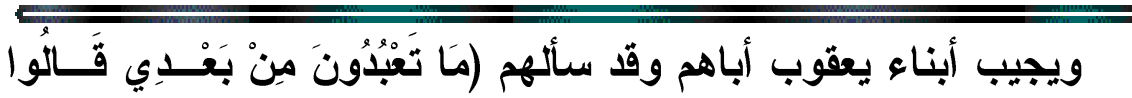

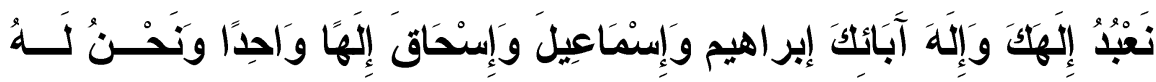

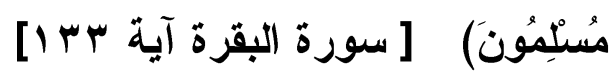

ويوسف عليه السلام في موطن الإقرار بنعم الله تعالى يسجد تحـــ

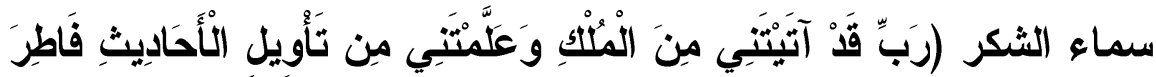

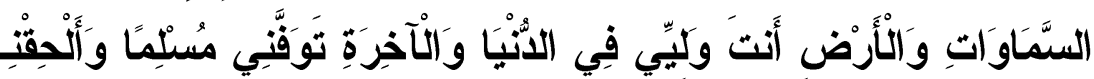

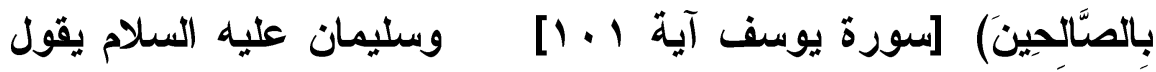

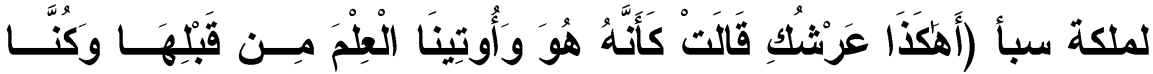

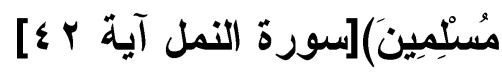

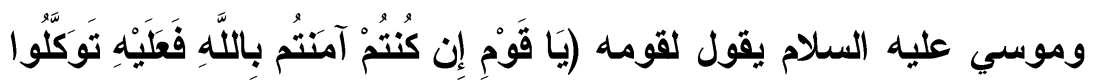

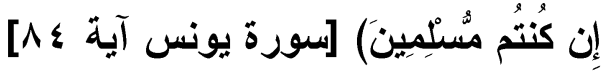

ويقوم الحق جل وعلا في الدفاع عن عيسي عليه السلام (مَـــا كَــانَ

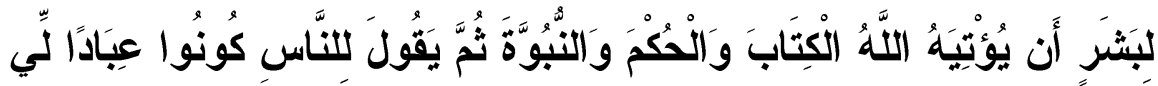

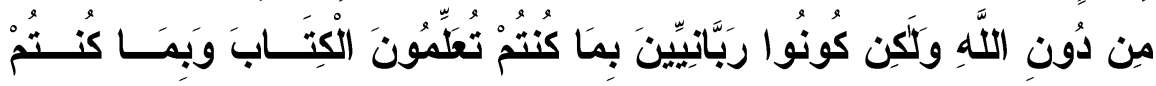

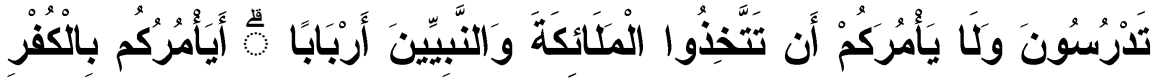

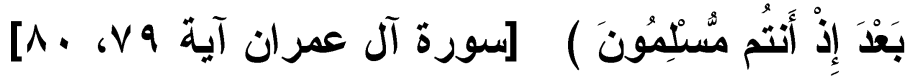

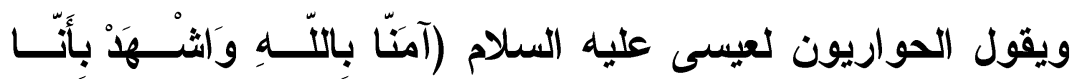
مُسْلِمُونَ)[سورة أل عمران ويقول فريق من أهل الكتاب بعد سماعهم القرَآن الكريم : (إنَّهُ الْحَقُّه

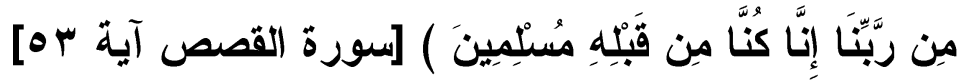


وإذا كانت هذه الأمة الأخيزة تعد من كل الوجوه المسئولة عن تبليغ

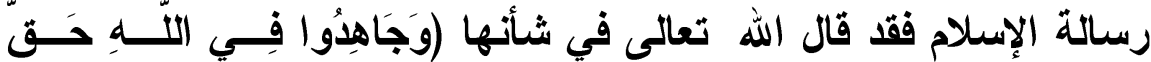

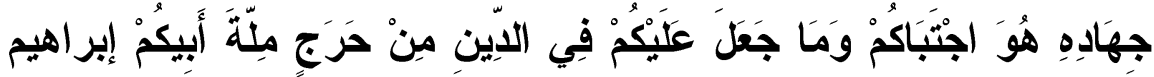

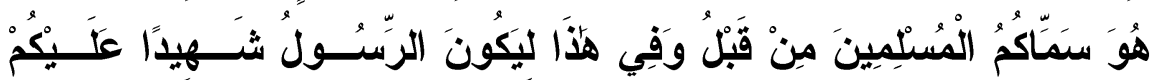

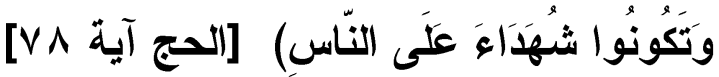

أما الرسول الكريم خُقه ولا عبادته

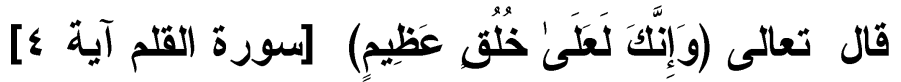

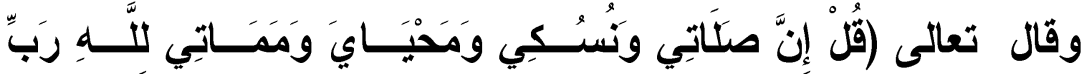

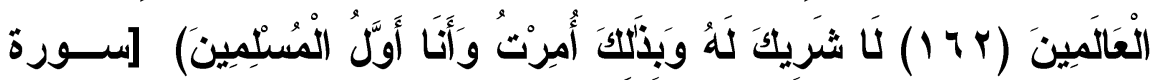

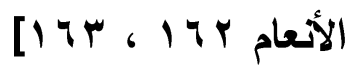

والإسـلام الأي أوحي الله تعالى به لجميع الأنبياء والرسـلـ ، ديـن

$$
\text { واحد في اصوله وفي عقائده جميعا }
$$

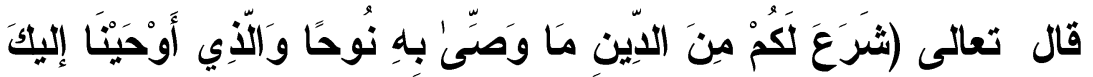

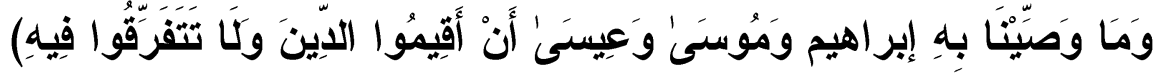

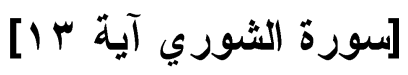

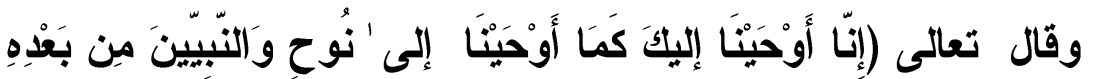

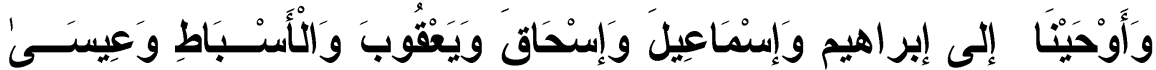

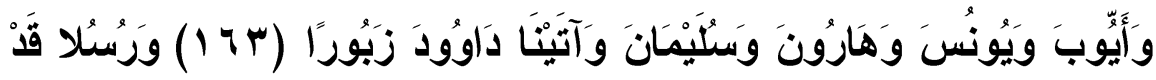

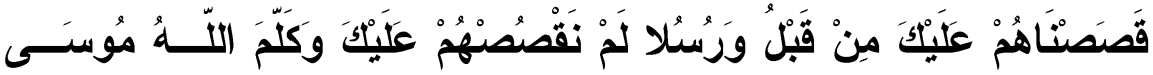

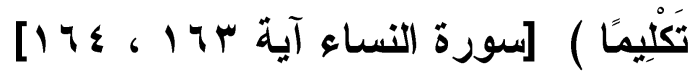


وهناك في اختلاف الأحكام العملية التشريعية دون العقديـــة ظـــاهرة

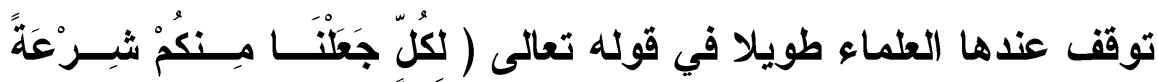

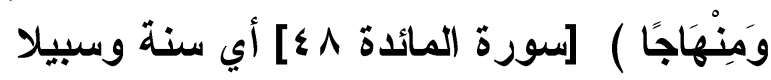
ولعل ذلك يرجع إلى مر اعاة مقتضيات الأحوال ، والزمان ، ومر اعاة لسنة التدرج في الأحكام ونستطيع - في مجال تحديد وحدة الدين - أن نقرر ما يلي :

\section{أ ـ توحيد الربوبية والألوهية:}

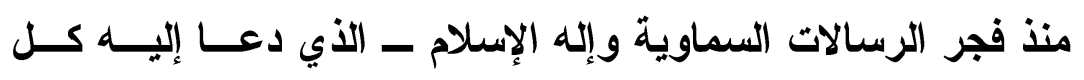
أنبياء الله ورسله واحد في ألوهيته ، واحد في ذاته ، وصفاته ، وأفعاله

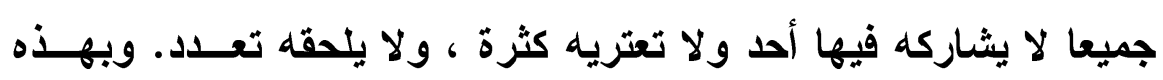

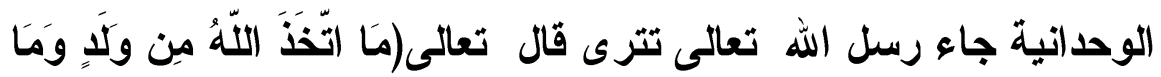

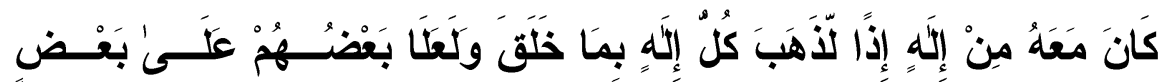

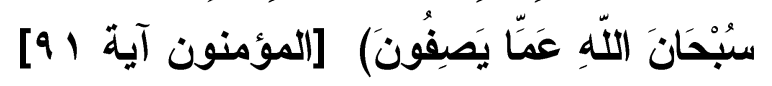

ومهما يكن من شيء فقد ظل القرآن الكريم قادرا علي اقتحام قضية

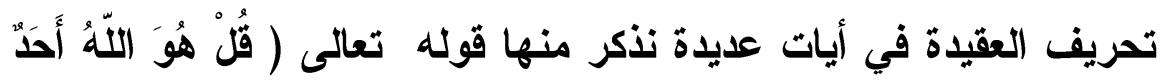

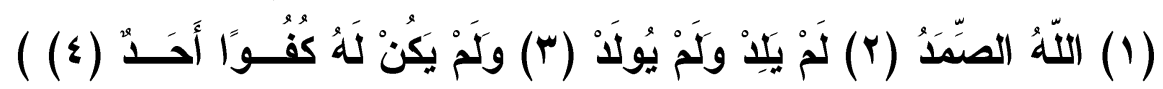
[سورة الإخلاص]

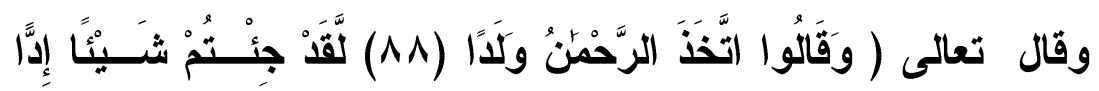

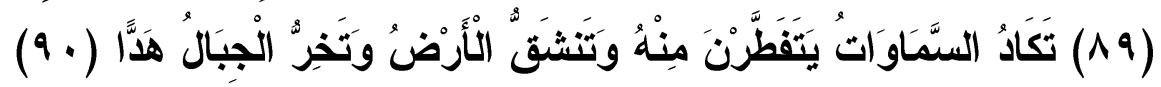

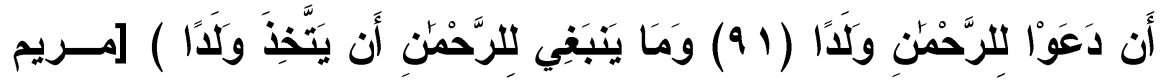

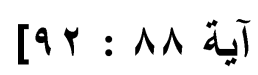




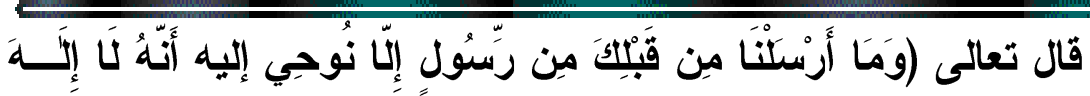

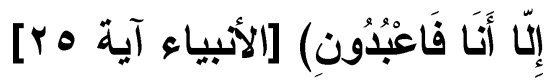

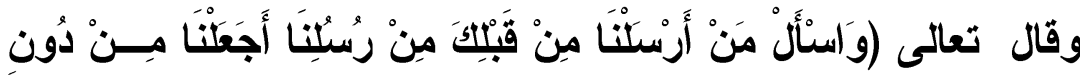

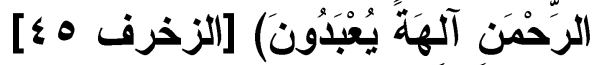

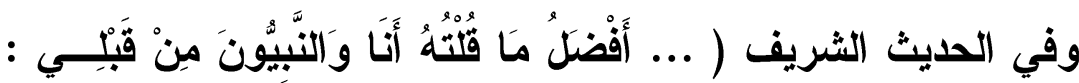

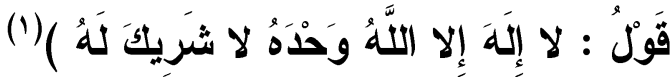
وكان ذللك كله وغيره من الآيات القرآنية الكريمة مـن أجـل عـدم ارتياد مناطق للتعبير عن الخالق جل وعلا بالصور الماديــة المحســة . وتلكك كاتت أهم وأثث دعوة للأنبياء جميعا وتظهز خصائص الوحدة الاينية أيضا فــي

\section{ب ـ وحدة النبوة:}

منطقية الربط والتعليل تؤكد أنه إذا كان لا خلاف في الحكــم عـــي وحدة الربوبية والألوهية فلا خلاف علي وحدة النبوة ـ فالله تعالى بعـد أن ذكر طائفة من الأنبياء في سورة تسمي باسمهر ـ الأنبياء ـ وهم : لوط ، ونوح ، وداود ، سليمان ، وإدريس ، وإبراهيم ، و إبــماعيل ، و إسحاق ، يعقوب ،وأيوب ، ويونس ، وزكريا ، ويحيي ، وعيسى عليهم

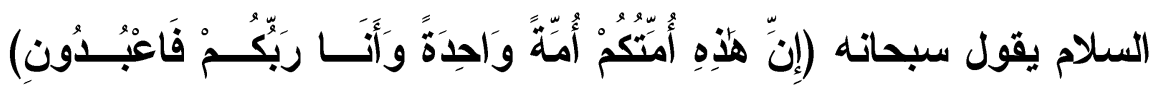

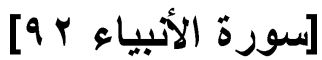

(1) أخرجه الترمذي في سنته- كتاب الاعوات عن رسول الله - باب في دعاء يـوم

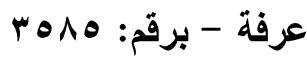




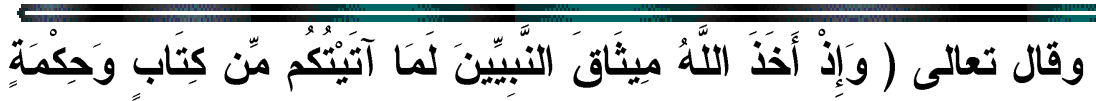

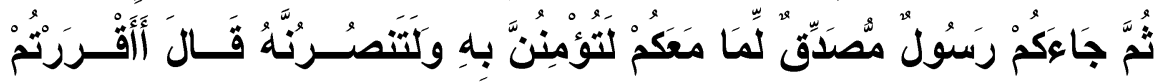

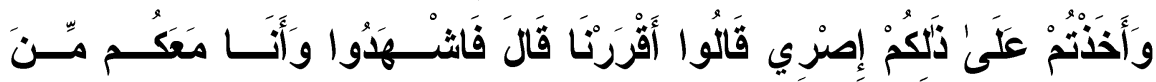

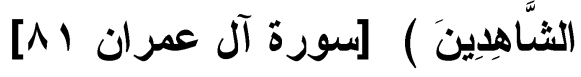

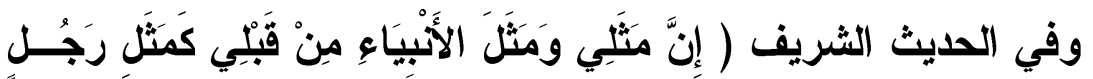

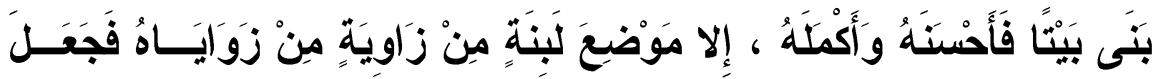

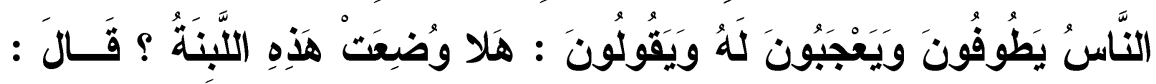

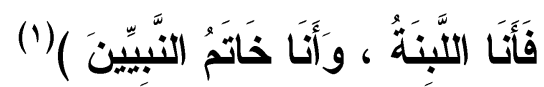

وقال

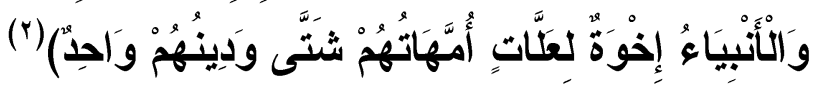

يؤكد بكله هذه الوحدة بطريقة عملية حين يتوجه من مكة إلى المدينة،

ويلتمس نوعا من الود الأي لم يفقد في زحمة التـــر اكض الإنســاني -

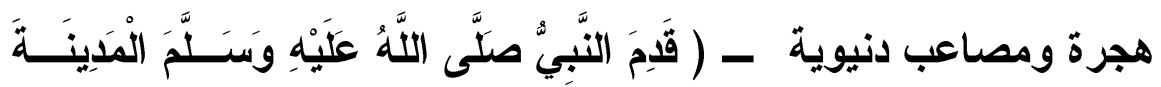

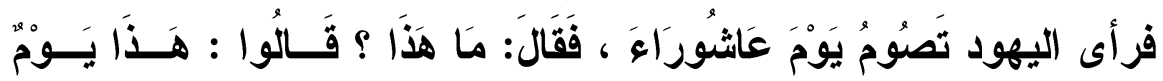

(1) أخرجه البخاري في "صحيحه"( كتاب المناقب ، باب خاتم النبيين صلى الله عليـهـ

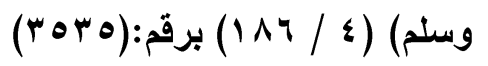

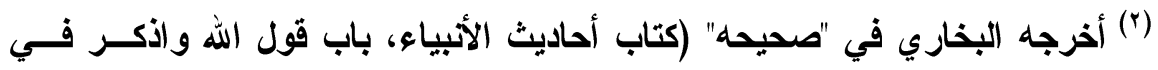

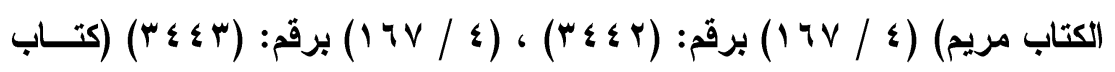

أحاديث الأبياء، باب قول الله واذكر في الكتاب مريم) ومسلم في "صحيحه" (كتاب

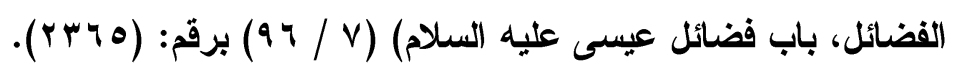




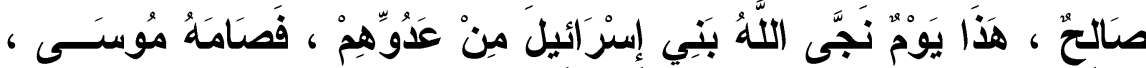

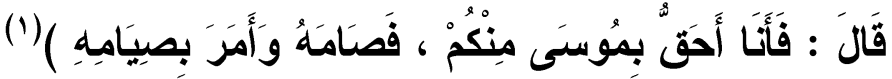

وهكذا تظهر القيمة الحقيقية لدور هذه الأمة فــي توضــيح دعـوة

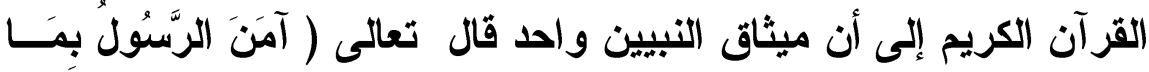

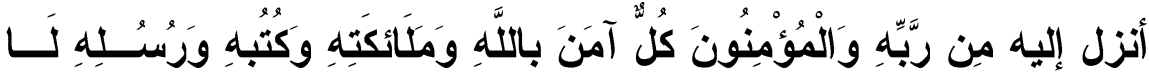

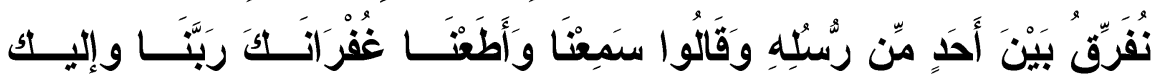

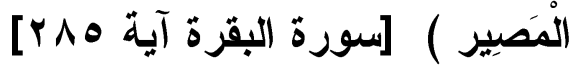

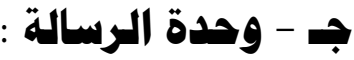

تتبدى بوضوح وحدة الكتب السماوية في العقيــة ، وإن كـــن ثــــ

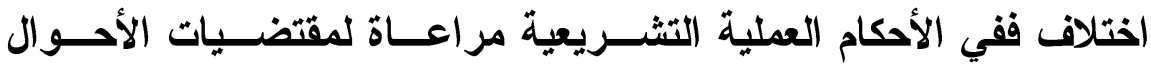
و الزمان ، ومراعاة لسنة التدرج في الأحكام - كما ذكرنا آنفـــ - قــال

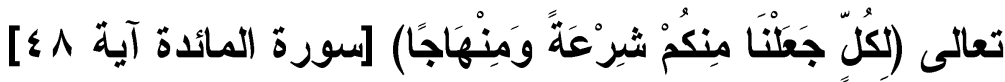
وقد جاءت الكتب السماوية مصدقا بعضها لبعض ـ- في غير ما أدخل عليها من تحريف - فجاءت توراة موسي مصدقة لما قبلهــا ، وجــاء إنجيل عيسي مصدقا للتوراة ـ وجاء القرآن الكريم مصدقا لهما ولغيرهما

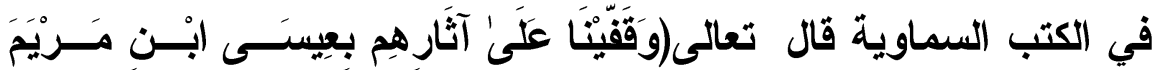

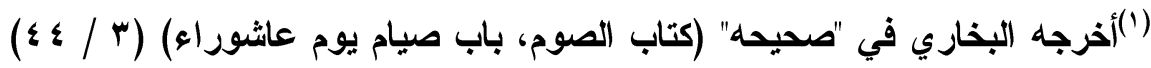

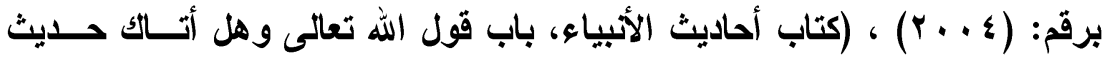

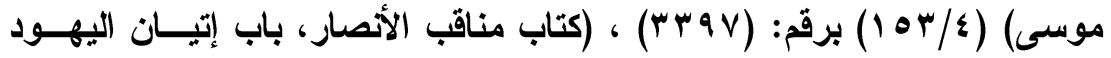

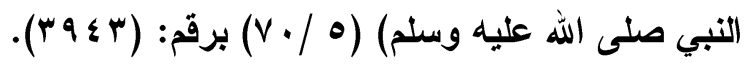


مجلة كلية الكراسعات الرإسلامية والعريبة بنات بنهي سويفعالعذى العاشر

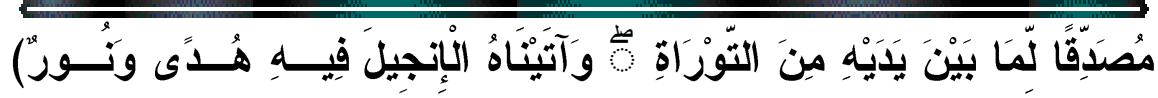

[سورة المائدة 7 \&

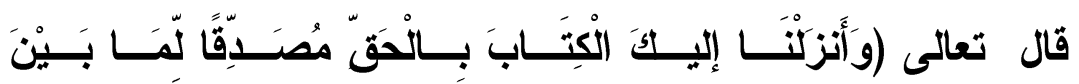

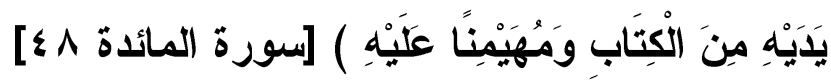

فلما كانت الأديان السماوية كلها وحدة إيمانية متر ابطة تســلم كـلـل عقيدة فيها إلى الأخرى، وتثري كل شريعة فيها مرحلة.... وهــذه ســـة الوحي الإلهي الأي يتناغم مضمونا، ويتو افد شريعة.

ولكن مع اختلاف التشريعات السماوية من رسالة إلى أخري فقد قال

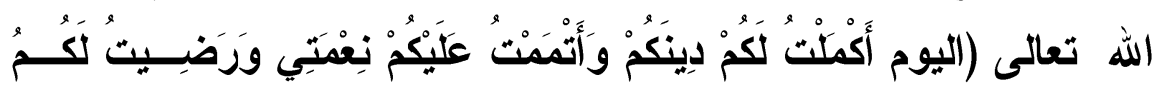

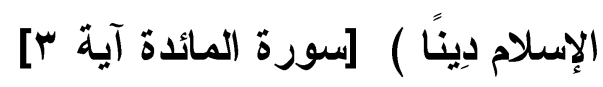

مما يؤكد أن التدرج التشريعي الأي اقتضت الحكمة الإههية تجديــــه للناس وصل إلى الغاية. ويعني ذلك بوضوح أمــران: الأول: أن النســـخ (ليس معناه إبطال حكم بأخر. وإنما معناه انتهاء حكم لا انتهاء حكمته مضامينه وحكمته حبيسة عصره وبيئته - وتجديا حكــ آخــر لحكمــة أخرى ، ولذلك كانت الأحكام السابقة في الكتب السماوية صائبة وحقا في

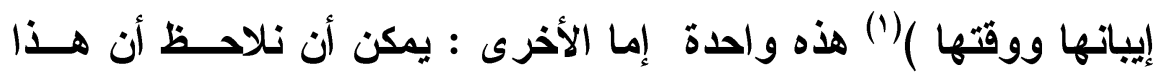
التصديق من الإسلام جاء علي ضربين أــ تصديق القديم مع الإذن ببقائه واستمراره .

(1) قضية التكفير والحكم علي المسلمين بين التطرف والاعتدال تأليف أ.د/المر اكبـي

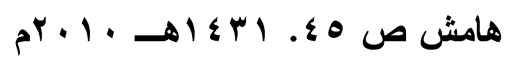


ب - وتصديق مع إبقائه في حدود ظروفه الماضية والوقوف به عند

وقته المناسب وأجله المحدود و المقدر ) (')

وإذن ما نعرف لسنة التدرج التشريعي من ذُرى ينبغــي أن تطمــح إليها البشرية غير شريعة الإسلام بالمعني الخاص وهو الرسالة الأخيرة. ومع ما في هذا المأخذ من حقيقة ، فإن علاقة الإسـلام بغيــره مــن الرسالات السماوية السابقة هي :

ا ـ علاقة التصديق بها مطلقا كيوم أنزلت ــ دون تغيير أو تحريــف لها - علي أنها الحق : في مجال العقيدة والثريعة جميعا ، لأنها علاقة

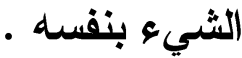
r. علاقة الإسلام بها بعد تغييرها وتبديلها علي يا مــن ينتســبون

وعلاقة الإسـلام بها علي هذا النحو هي : علاقة التصديق لما بقـي من الصحيح منها ـ والتصحيح لما غير أو بلد فيها ومن ثم جاء القرآن

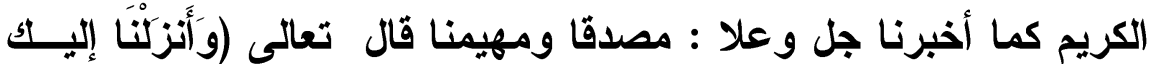

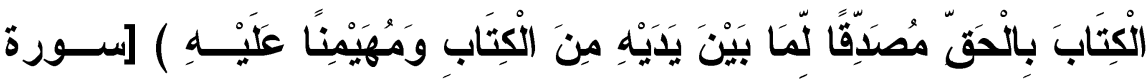

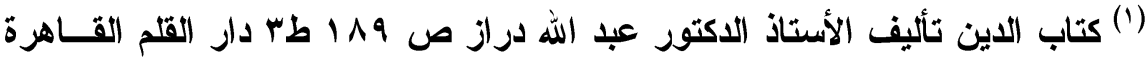
. 1 . 
مجلة كلية الكراسعات الإسلالمية والعريبة بنات بنميه سويفع العدذ العاشر

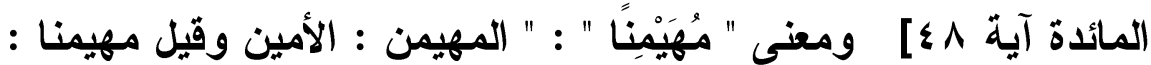

أي شهيدا ـ وقيل معنى مهيمنا : حاكما "(1)

\section{د - الوحدة الاجتمهاوية :}

الحس الإيماني والأخلاقي الأي أكدته آيات القرآن الكريم وأكده النبي

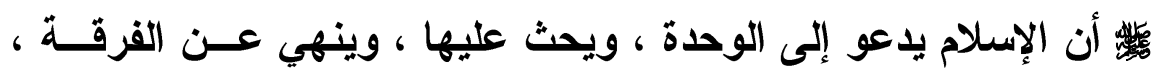
ويحذر منها ، ويتوجه الإسلام ـ في بضع سنين أو يزيل قليلا ـ ليجمع شتات الناس علي اختلاف: ألوانهم ، وأجناسهم ، ونحلهم ، ولغــاتهم ، وعصبياتهم ، وأهوائهم ـ لينصهروا جميعا في بوتقة واحدة والإسلام في رفضه النهائي للتفرق والتحزب والتناحر الواقع فـي صــر اء العـرب وغيرها ـ نجد قلوب العرب كاتت ولا تزال لا تصيخ إلا لقول الله ورسوله

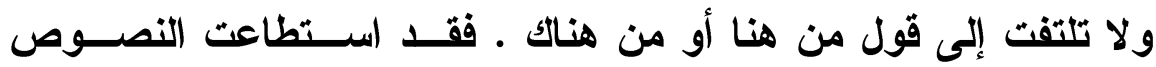
الثرعية أن تجعل من الأحزاب المتناحرة ، والقبائل المتفرقة ، والأشلاء

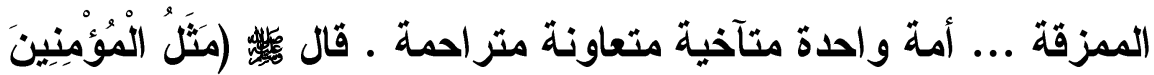

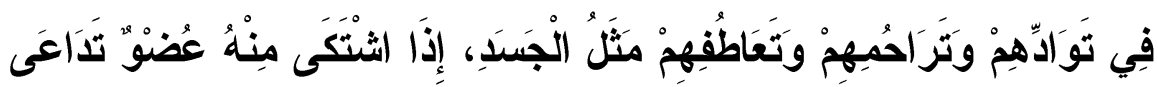

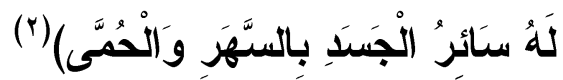

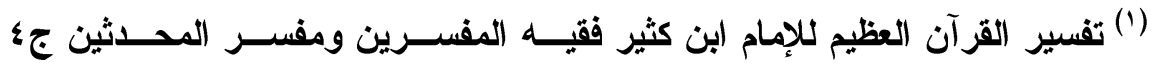

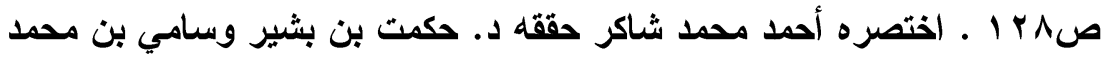

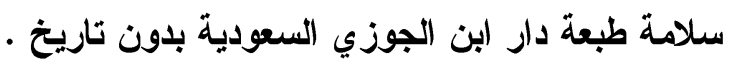

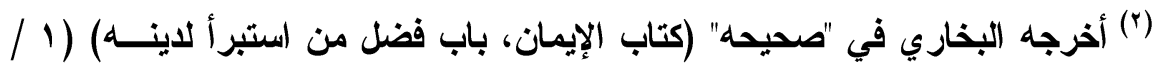

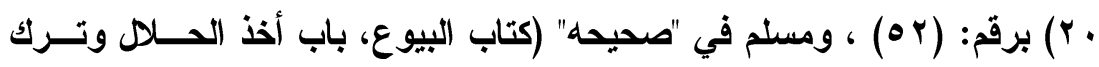

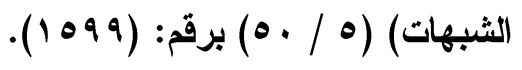


هذه الوحدة الرائعة بين المسلمين يذكرهم الله تعالى بها في قولــهـ.

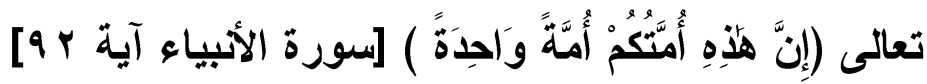
وفطن المسلمون إلى أن هذه الوحدة من منن الله عــيهم وبــالقطع

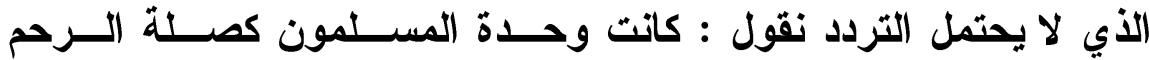
الموصولة بينهم

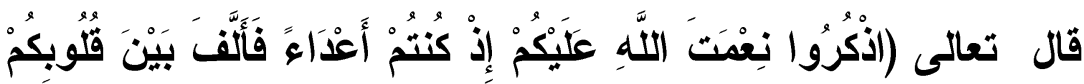

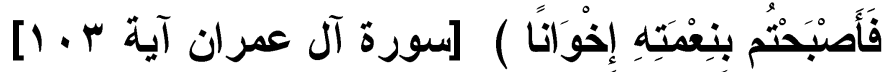

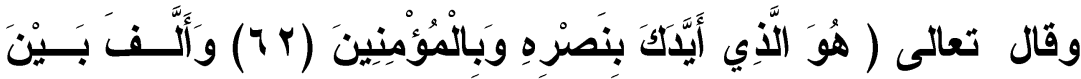

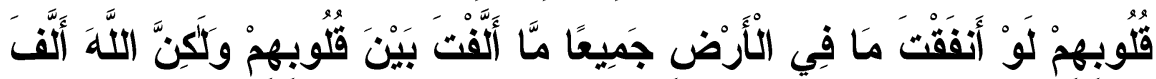

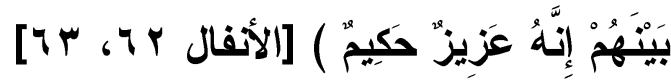
و الواقع أنتا لا نعاني طويلا لنفهم أن الإسلام في سبيله للإبقاء علي

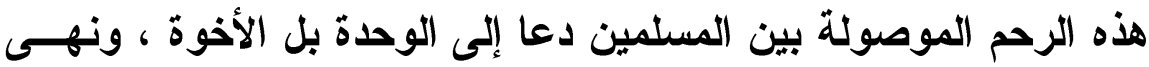

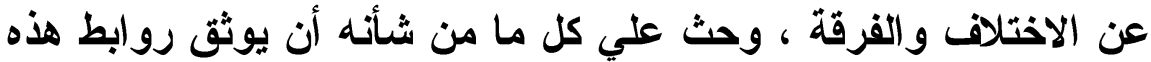

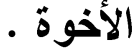

ومن خلال عبادات فائقة الكمال والجمال شرع الله تعسلى خمسس صلوات في اليوم والليلة ، وصلاة أسبوعية ــ الجمعة ــ وصلاة العيدين واجتماعا سنويا محدود الزمان و المكان ـ الحج ـ وشهرا تصوم الأمسـة

$$
\text { فيه - رمضان - ... إلخ }
$$

ونستطيع أن نقرأ مقاصد هذه العبادات وغيرها قراعة تخرج بنا عن

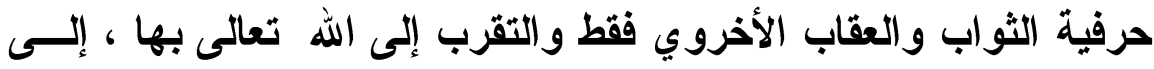


مجلة كلية الكراسعات الإسلإمية والعريبة بنات بنهي لسويفه العذى العاشر

محاولة تجسيد الوحدة الإسلامية أيضا كمعادل موضــوعي للثـواب ، أو المصير الأخروي - (المصي

فإذا أدرنا القضية علي الآيات القرآنية والأحاديث النبوية التي أمسـر الله تعالى فيها رسوله و المؤمنين بالتزام الجماعة ، ونهاهم الله تعسالى ورسوله عن الفرقة نهيا متكررا فسنجد علي سبيل المثال لا الحصر •

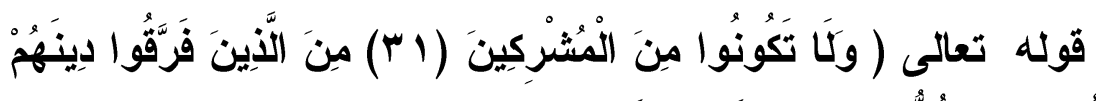

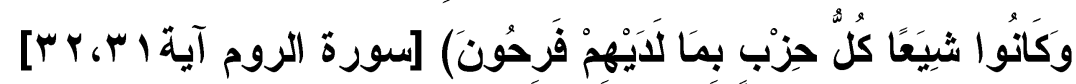

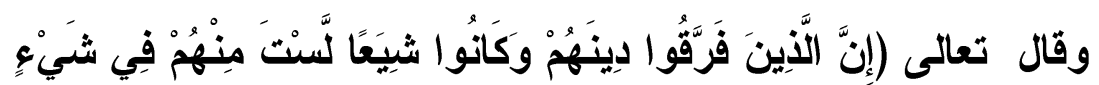

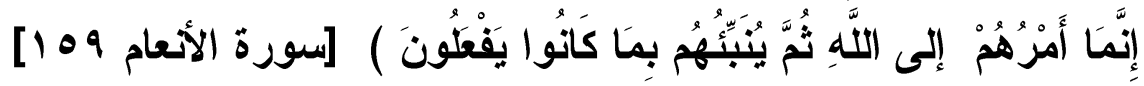

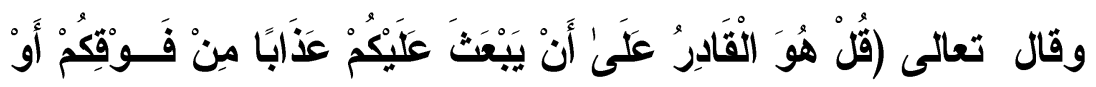

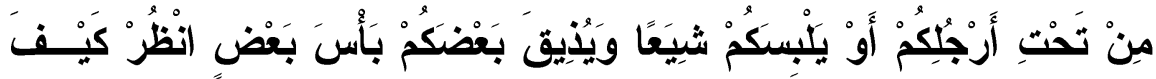

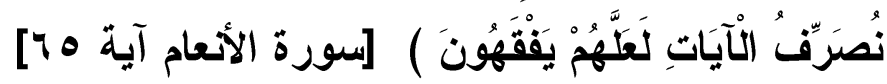

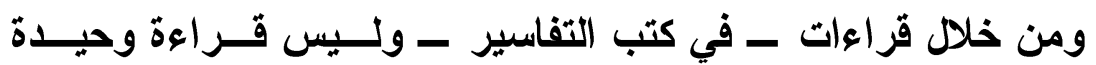

فحسب نجد أن هذه الوحدة تستوعب عند هارون عليه الســلام الوجــود كلهه، وتحاصره فلا يمتد تفكيره عليه السلام إلى أبعد من الوحدة وكأنمــا عشقها ـ لارجة اعثذاره لموسى عليهما السلام فقد كفر بنــو إســـرائيل حين أضلهم السامري حتي عبدوا عجلا جسداً له خوار ، وقال هذا إلهكم وإله موسي فلما جاء موسي عليه السلام وكان يتلقى الألواح من ربـــه

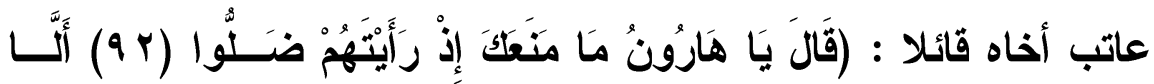

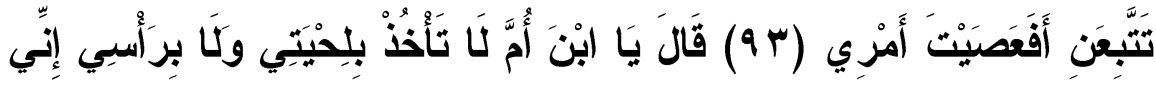

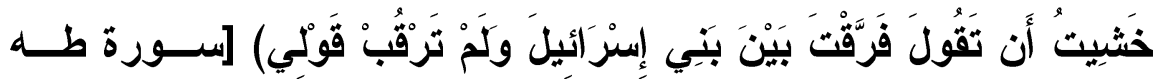


آية 9 : ع 9] فكانت معذرة هارون لأخيه موسى عليهما السلام " إنّي

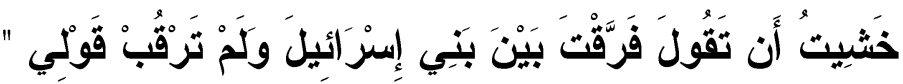

ولقد وعظهم هارون عليه السلام وعظا رقيقــا حتـــي لا يتجـــاوزوا

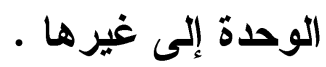

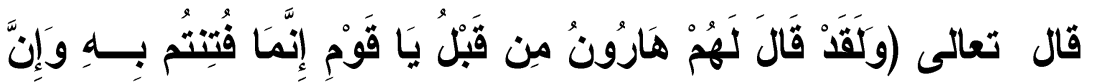

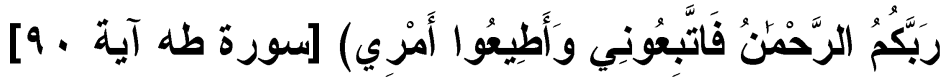
فلما عصوا أمره وأصروا واستكبروا صبر علي شركهم حفاظا علي وحتهم !! ولم يتجاوز هارون وحدتهم حتي يرجع موسي فيدبرا أمرهما. فلماذا لا نفهم من الآية أهمية الوحدة ... وأن صبر هـارون عليـه.

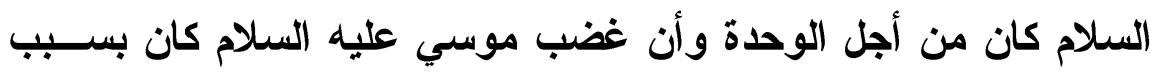

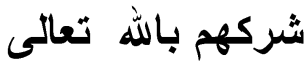
ألسنا مطالبين بالوحدة لأن الفرقة من شأنها أن تــوهن روح هـــه

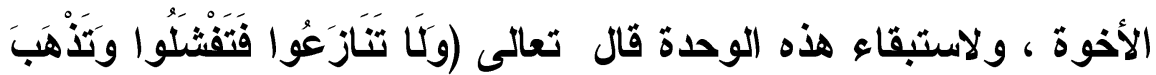

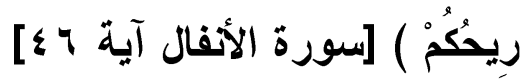
وأخبر النبب

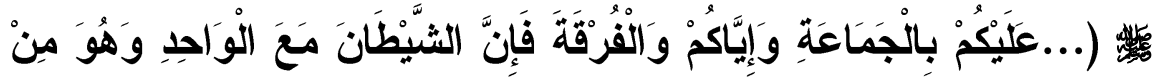

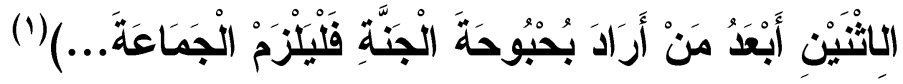

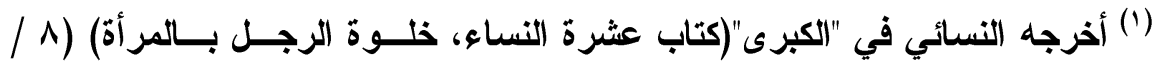

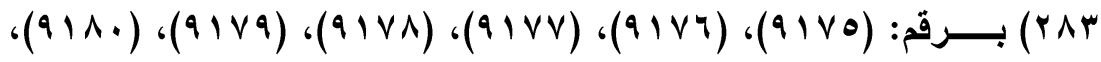

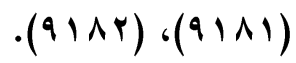


وفي الصحيحين عن ابن عباس رضي الله عنهما قال (: مَنْ رَأَى مينْ

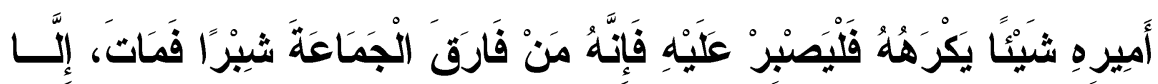

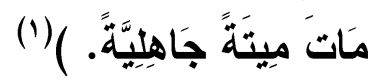

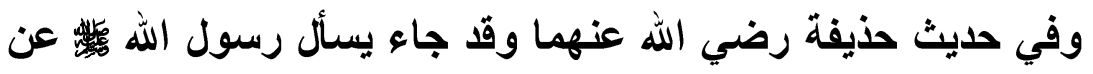

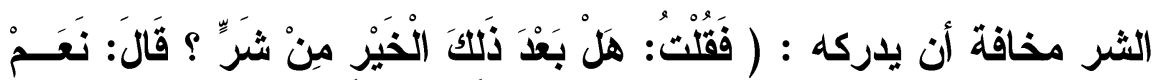

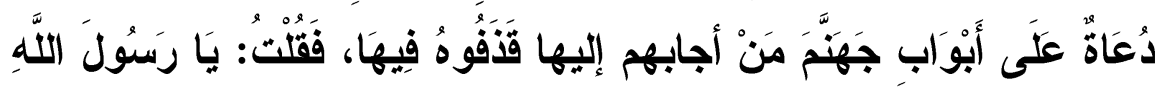

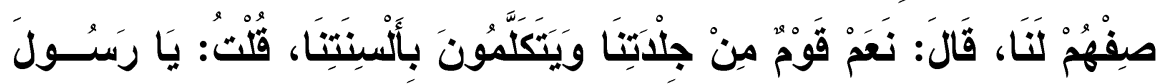

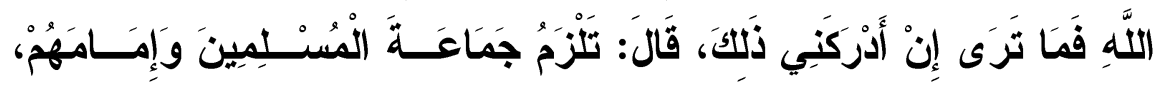

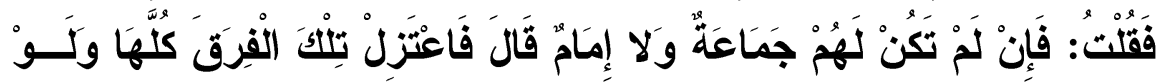

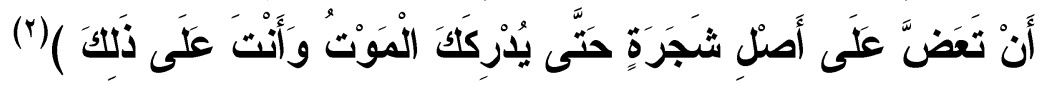

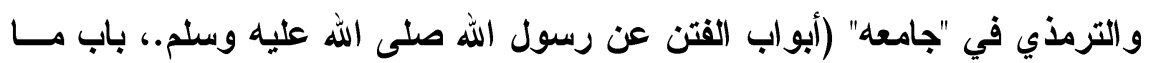

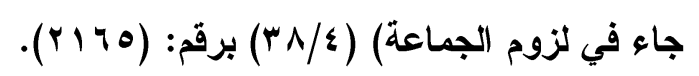

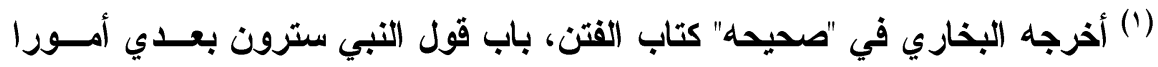

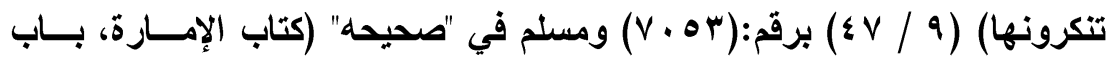

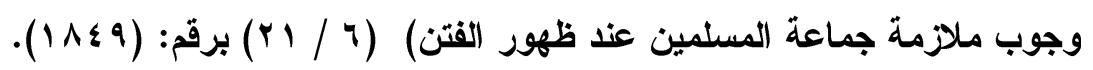

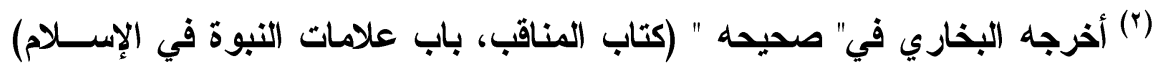

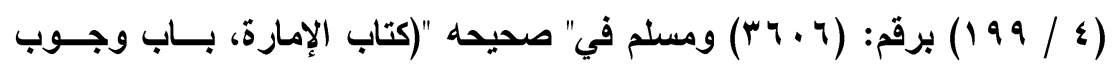

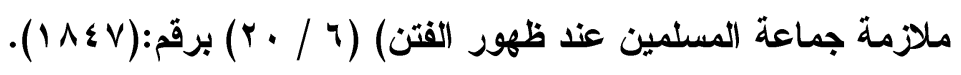




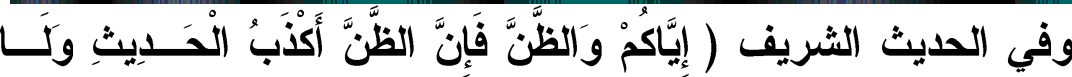

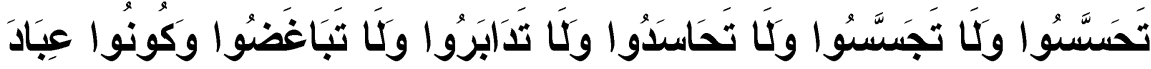

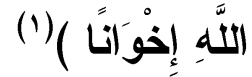

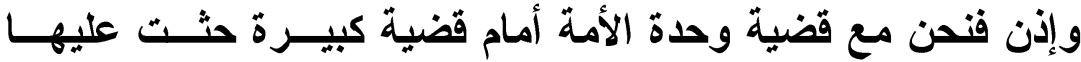
النصوص الثرعية ، وفجرت في العرب معاني الأخوة فبدوا علي غير ما كانوا عليه من التناحر والفرقة بل الأثشلاء الممزقة فقد جعهم الإســلام

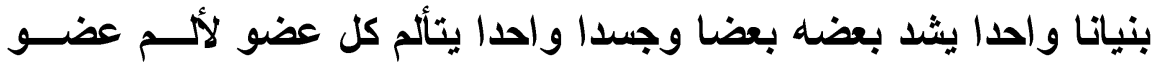
فيه. وأمة واحدة متآخية متعاونة متر ابطة متر احمة .

\section{الوحدة السياسية : - (الوية}

نستطيع أن نقول: شرع الله نظام الحكم - سياسة الدولة - ووضـــع

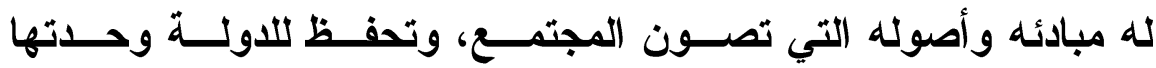
واستقلالها. فالإسلام دين ودولة .

وتدور قضية السياسة في عالمين متناغمين : الحاكم والمحكوم وهذا ما ينبغي أن ننقب عنه حتي نعرف حقوق وواجبات كل منهما على الآخر

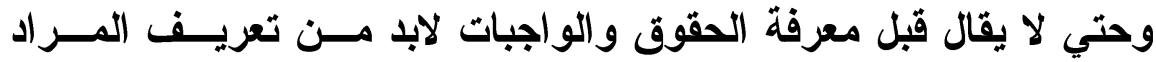

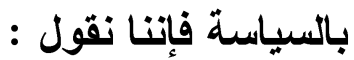

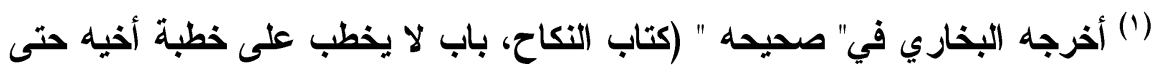

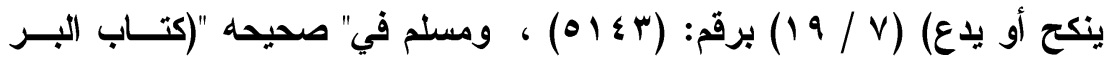

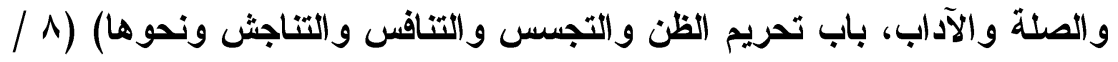
• (1) برقم: (rآهم). 
السياسة الشرعية - النظم السياسية - البارز في تعريفنا للسياســة الشرعية أنتا لا نجعل السياسة الشرعية مجرد روئية خاصة لعلماء اللغة أو لعلماء اصطلاح كل فن من الفنون كالفقهاء أو علمــاء الاجتمــاع أو غيرهم ، وإنما إلى نقطة انطلاق إلى تعريف يضم هؤلاء وانطلاقــا مسن ذللك نقول (السياسة الشرعية هي تدبير الثؤون العامة للاولة الإسلامية بما يكفل تحقق المصالح ، ودفع المضار مما لا يتعدى حــدود الثــريعة وأصولها (الكلية)(1) والمراد بالثؤون العامة للاولة كل ما تتطلبه حياتهم من نظم فالإسلام جعل الأمة مصدر جميع السلطات ، وعلي الأمة أن تختــار من بينها ما تراه أهلا لتحمل هذه التبعة ، التي تحفظ علي الأمة دينهــا ودنياها معا .

وإذن فمناط الأهمية في الوحدة السياسية هي مراعاة كل ما تتطلبــه حياة المسلمين من نظم وهذه أعظم واجبات الاين هكذا يقول ابن تيميــة (يجب أن يعرف أن ولاية الناس من أعظم واجبات الاين ، بـلـل لا قيــام للاين إلا بها ، فإن بني آدم لا تتم مصلحتهم إلا بالاجتماع لحاجة بعضهم

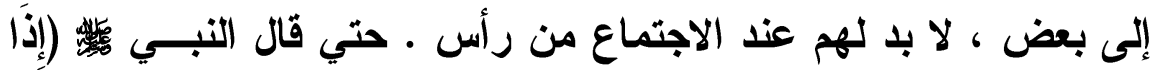

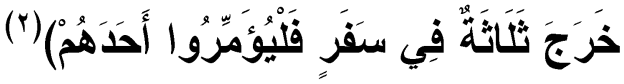

(1) (لسياسة الثرعية تعريف وتأصيل. تأليف محمد بن شاكر ص بr الطبعة الثانية

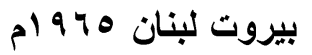

(r) أخرجه مسلم في" صحيحه "(كتاب المساجد ومواضع الصــلاة، بــاب مــن أحسـق

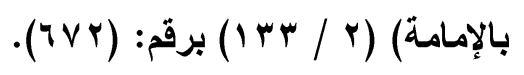


وهناك في فكر العلامة ابن خلاون ما يؤكد أهميــة الحسـاكم يقــول مؤسس علم الاجتماع إذا (لم يكن للحاكم الوازع ، أفضى ذلك إلى الهرج الهرج

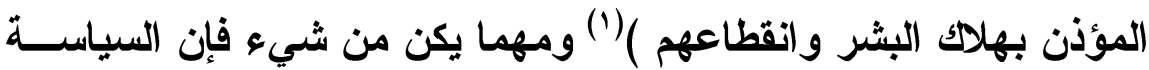
الثرعية (هي نيابة عن صاحب الثريعة في حفظ الدين ، وسياسة الدنيا

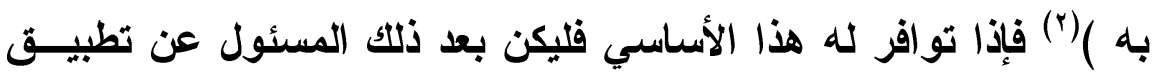

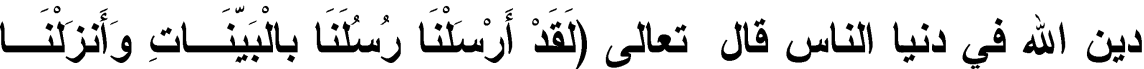

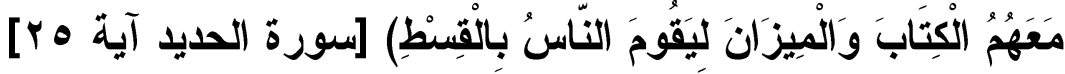
وقد كان ئس يدعو إلى الالتزام بتحكيم دين الله فــي دنيــا النــاس ، وحرص الخلفاء الراشدون رضوان الله عليهم أجمعين ، على أن يكونوا علي ما كان عليه ونستطيع في مجال تحديد وتحقيق الوحدة السياسية أن نقـول : إن

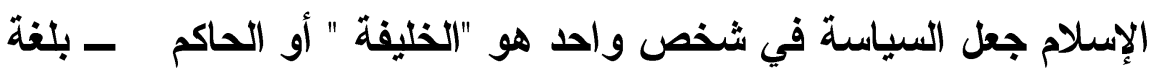

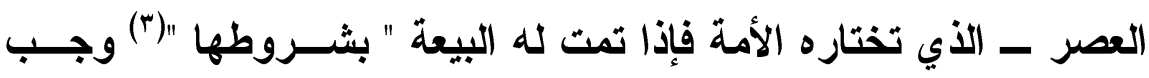

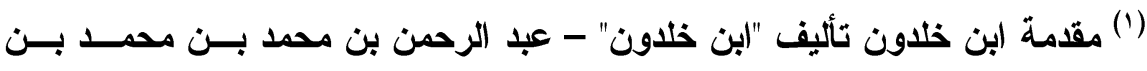

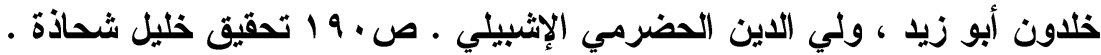

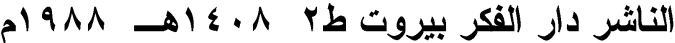

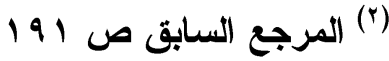

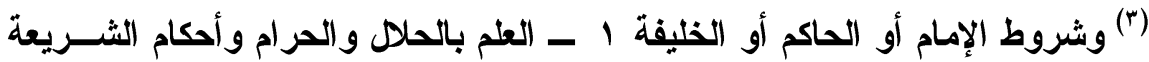

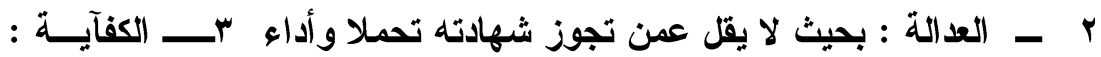

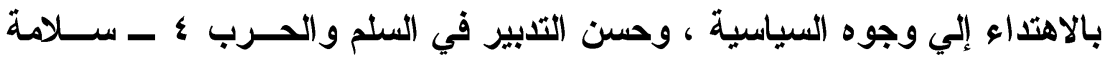

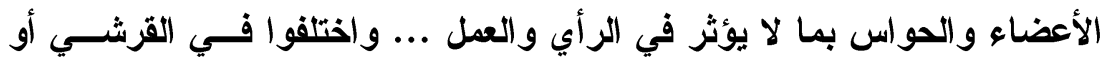
$=$ 
علي المسلمين طاعته ومساندته ، و تقديم النصح لله ـ ما دام قائما علي أمر الله فيهم المي المبن

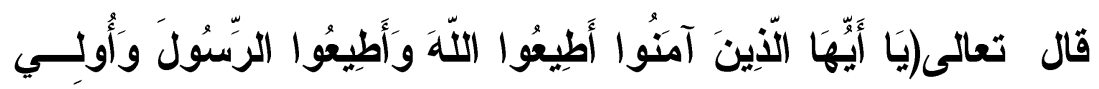

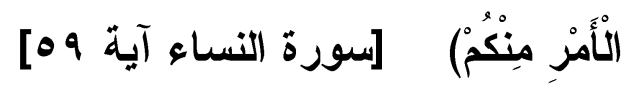

يقول الإمام ابن كثير في تفسير هذه الآية (وقال علي بن أبي طلحة،

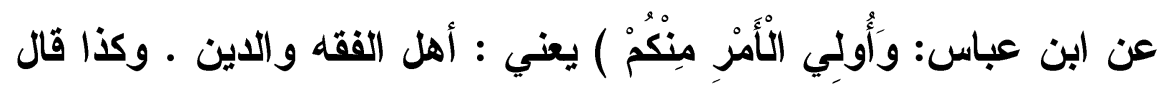

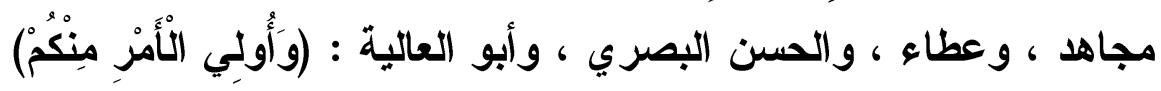
يعني : يعني العلماء ، والظاهر - والله أعلم - أن الآية في جميع أولي

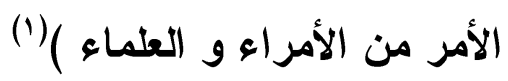

وقد أعطي الإسلام للحاكم وجوب الالتزام بطاعته فكان إتمام البيعـة للحاكم مدخلا للوفاء بها والآتز ام بأمره ونهيه متى كانا ـالأمر و النهي ـ من باطن طاعة الله ورسوله

غيره. انظر الأحكام السلطانية تأليف علي بن محد الماوردي صل ا. طبعة دار

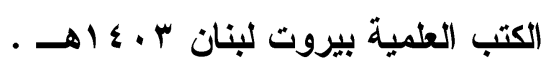

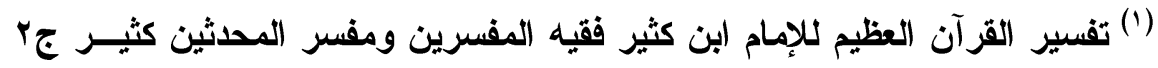

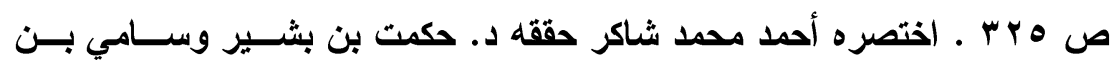
محد سلامة طبعة دار ابن الجوزي السعودية بدون تاريخ 
فقتد روى عن النبِي

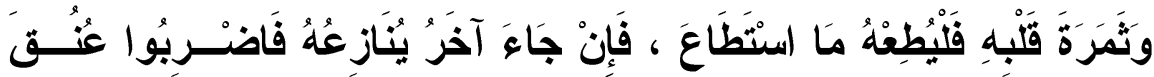
الآخَرَ )(') أليس هذا الحديث دليلا علي عدم تعدد الأيمة في وقت واحد . وقد كان بـ يحرص علي القول بإمام أو خليفة أو حاكم واحد يقــول

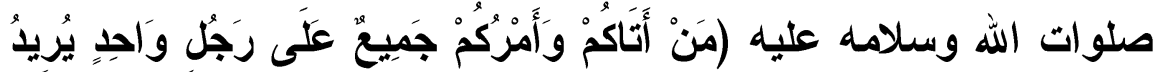

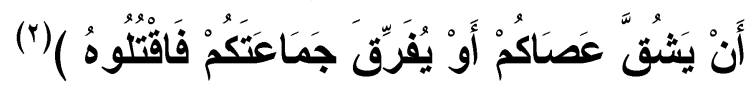
ويجب أن نأخذ من هذا الحديث أن (الإمام علياً كرم الله وجهه ووجه الصحابة أجمعين لم يقاتل الخوارج لشركهم أو نفاقهم ولكن لخــروجهم (r) (c)

ولسنا نري في مراقبة الحاكم ، ومحاسبته ما يجرنــــا إلــى الحكـــ المتسرع بوجوب عزله. إن أخل بشروط عقد البيعة ـ والخــروج عليــهـ بالسيف ، أو بالقوة لأن لعلماء أهل السنه من أهل الحديث وحتـى مـنـ ياعي السلفية وكذلك الأثعرية وغيرهم دعوة إلى الآتزام بما بسمي في الثريعة "ارتكاب أخف الضررين"

(1) أخرجه مسلم في" صحيحه "(كتاب الإمـارة، باب الْأمر بالوفاء بييعة الخلقاء الْــأول

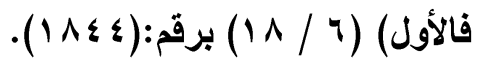

(ץ) أخرجه مسلم في" صحيحه " (كتاب الإمارة، باب حكم من فرق أمر المسلمين وهو (1) بره

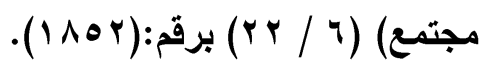

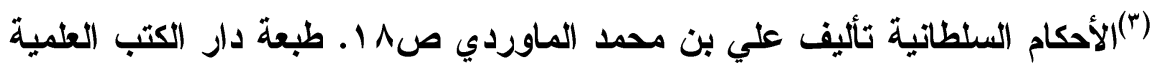

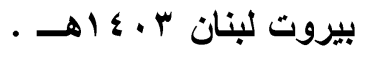


فإذا كانت طاعة الحاكم المستبد أخف ضررا من عزلــهـه بـالثورة أو

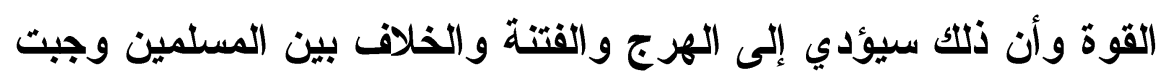

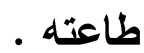

ونكتفي هنا بقول الإمام الغزالي الذي حكم علــي القضــية بمنطــق

$$
\text { "ارتكاب أخف الضررين" }
$$

يقول حجة الإسلام (والذي نراه ونقطع به ، أنه يجب خلعه إن قــدر

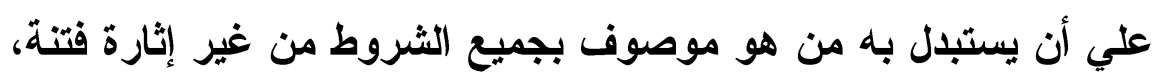

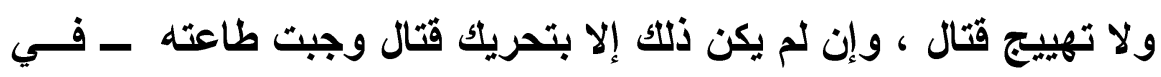

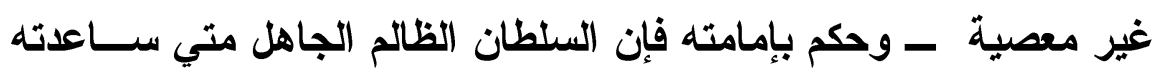

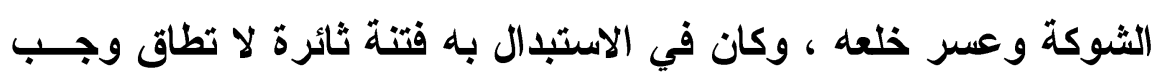
(') تركه (1)

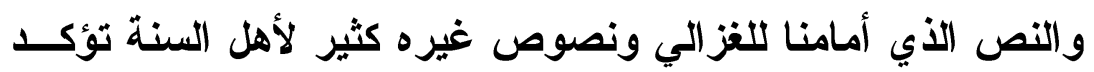

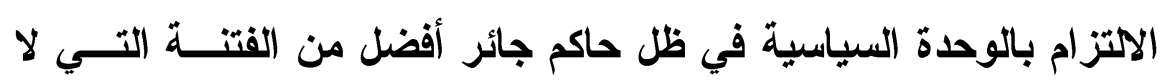
ت تبقي ولا تذر مالوحت

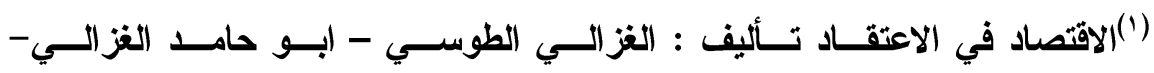

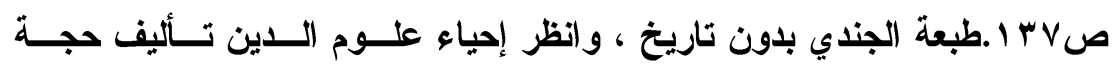

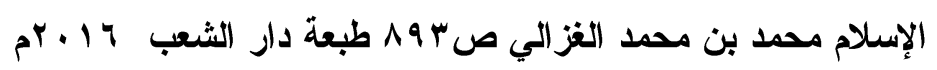


وقد أذهلتنا هذه الوحدة الإسلامية بأنواعها المقتدرة التي دارث حول طابع الوسطية الإسلامية الذي هو "أعظم ما في هذا الاين وأصــب مـــا فيه" (1)

وقد كاتت هذه الوحدة أيام عز المسلمين عندما كاتت حرارة الإيمان في قلوبهم قوية فقد قال

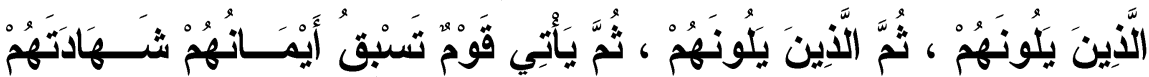

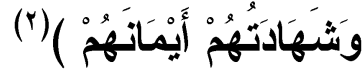

وعندما ضاعت الوحدة المنشودة التي مكنت الأمسة من إعلان حريـــة الاعتقاد في أنحاء المعمورة وأصبح العالم الإسلامي الآن جزرا معزولــة ولكي نعطي الموقف ما يستحقه من المعاناة عبر تاريخ الأمم والحضارات

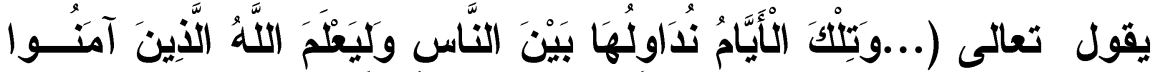

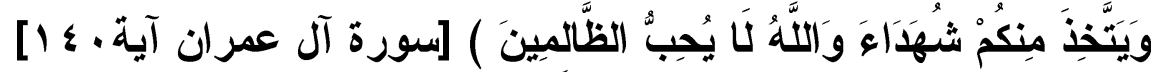

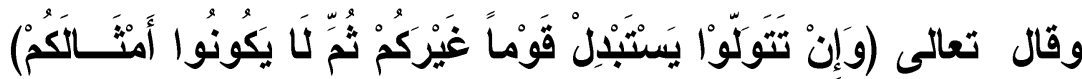

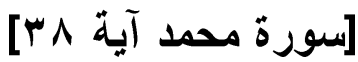

وإذا كان القرآن الكريم قد علمنا أن هذا "التداول" هو سنة الله فـي

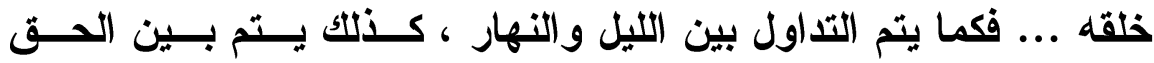
والباطل وبين الوحدة والتفرق

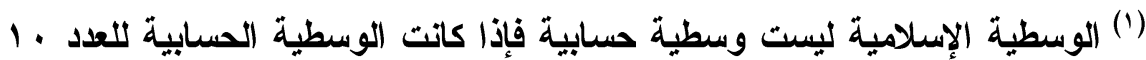

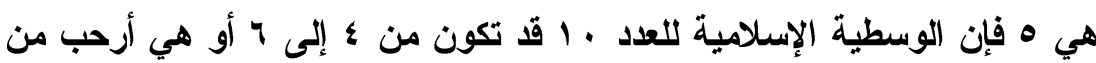

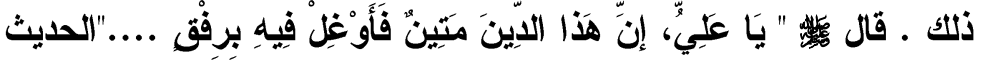

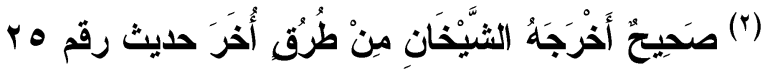


وعن حديث افتراق الأمة نقول : لابد من الاعتــراف بـأن حسديث

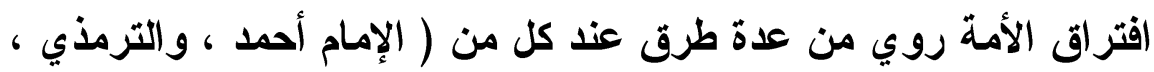

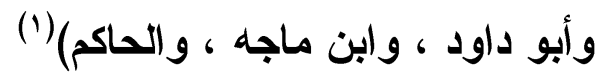

وجاء الحديث عند الإمام أحمد وأبي داود من رواية معاوية رضــي

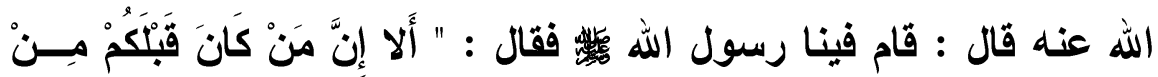

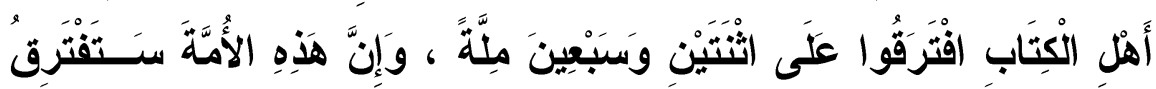

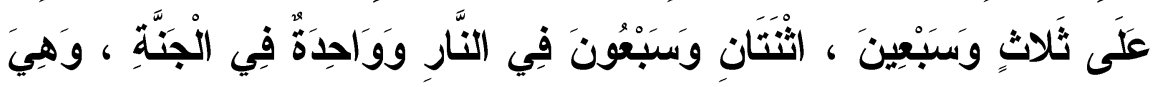

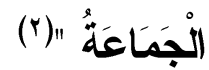

و رواه أبو داود و الترمذي وابن ماجه عن أبي هريرة ـــ رضي الله

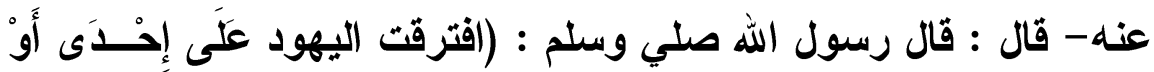

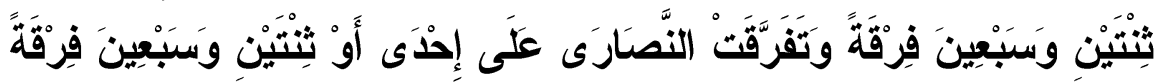

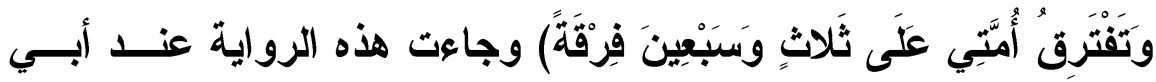

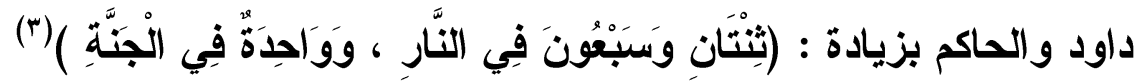

(1) ومما تجدر الإشارة إليه هنا : أن الحديث لم يرد فــي الصـحيحين - البخـاري

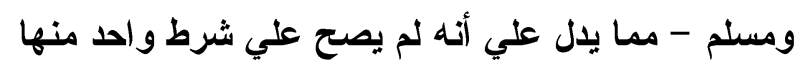

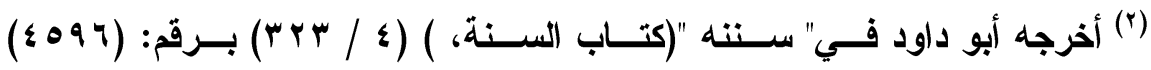

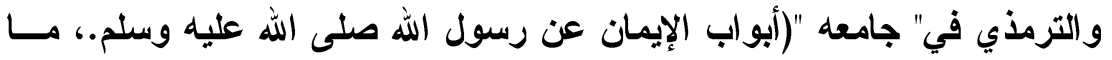

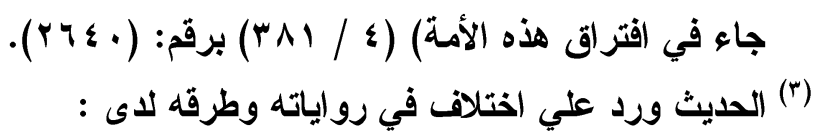

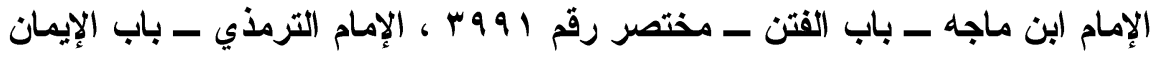

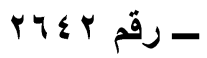
$==$ 


$$
\text { وقد كاتت عناية العلماء بالحديث فائقة حيث: }
$$

تكلموا في إسناده ، فمنهم من أثشار إلى تضــعيفه ـ ومسـنهم مــن

صححه. وإليك التفصيل

همقف الملمهاء هن أحاديث افتزاق الأهمة: اختلف موقف العلمــاء

من هذه الأحاديث علي آراء أهمها ما يلي :

أولا : رفض هذه الأحاديث جملة :

علي الرغم من تعدد طرق الحديث لم يقبله العلامة الألدالســي ابـن

حزم الظاهري لشكه في أسانيدها ، ولضعف طرقها في رأيه فقـــــ روى ابن حزم حديث : ( القدرية والمرجئة مجوس هذه الأمة وذكــر معسـه : حديث " تفترق هذه الأمة علي بضع وسبعين فرقة ، كلها في النار حاثـا واحدة فهي في الجنة " وذكر ابن حزم أن بعض الناس يعزوهـــا إلــى رسول الله فليس بحجة عند من يقول بخبر الواحد ، فكيف بمن لا يقول به )('ال ثانيا : قبول الأحاديث الواردة ورفـض التنصــيص علــي الناجيــة والهلكى :

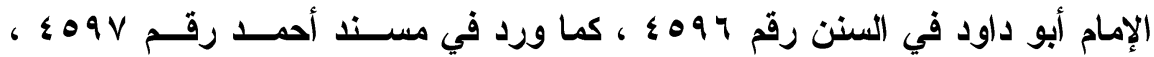

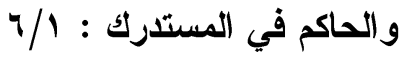
(') الفصل في الملل والأهو اء والنحل تأليف ابن حزم - أبو محمد علي بن أحمد بـن

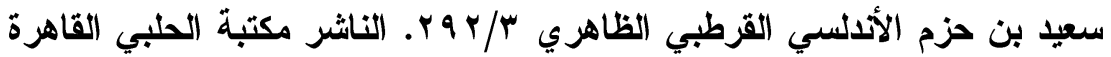


إذا أدرنا الحديث عن رفض الزيادة التي تنص علي الفرقة الناجية ،

$$
\text { والفرق الهلكى فستجد : }
$$

ابن الوزير يقول : " الحذر الحذر من التورط في تكفير أحد منهــا الأمة - وإياك أن تغتر بزيادة : " كلها في النار إلا واحدة " ، فإنها زيادة

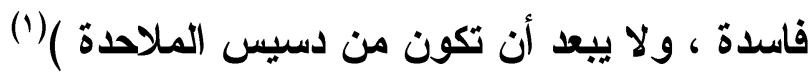

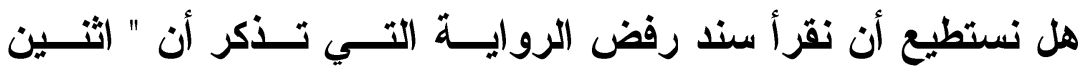
وسبعين فرقة في الجنة، وواحدة في النار ، فإن هذا التذييل هو نقـيض التذييل المشهور الذي ذكر أن " الفرق كلها في النار إلا واحدة " ، وعليه فإن الروايتين تعارضتا فتساقطا ، وبقي صدر الحــديث مقبــولا وهــذه الوضعية " كلها في النار إلا واحدة " ستجد كل فرقة تدعي أنها الناجيــة وغيرها الخارج عن الملة . يقول الأستاذ الإمام عبد العلـيم محمــود : (ولم يأل العرب الأين وصفهم القرآن الكريم بأن ألسنتهم حداد ، وأنهم الآاء الخصام جها في تصوير خصومهم بأنهم الاءع حـزب الثــيطان

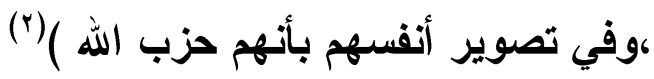

هكذا يقول الإمام عبد الحليم محمود ، وهي مقولة ـ الفرقة الناجية ـ ترددت عن سائر الفرق الإسلامية التي تناولت الحديث ـ حتـي قـال (1) (العواصم و القواصم في الأب عن سنة (بي القاسم ـ تأليف ابن الوزير - محمـــ

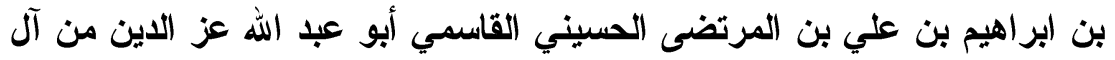

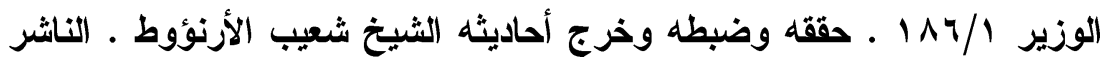

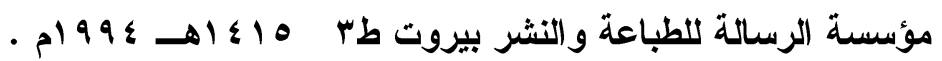

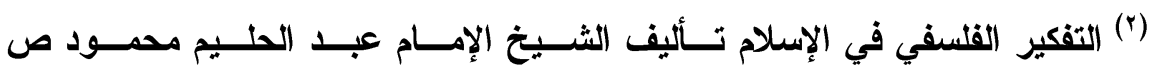

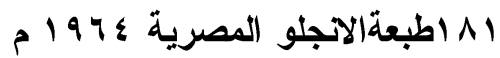


(ابن المطهر الحلي : قد باحثنا في هذا الحديث مع الأستاذ نصير الـدين

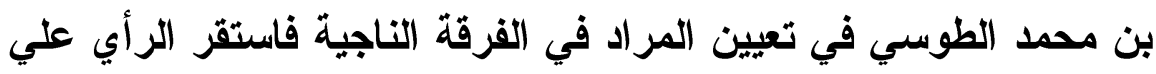

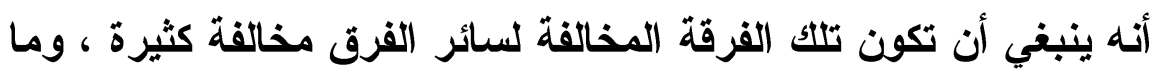

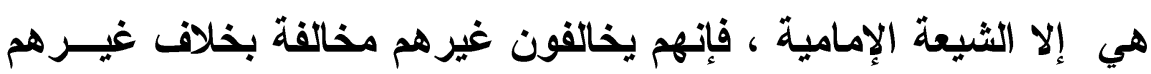

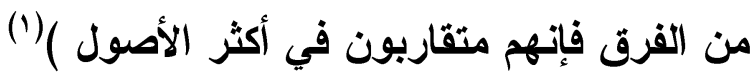
ثالثا: ـ قبول الحديث مع رفض مفهوم العدد :

ويتبدى بوضوح أنه في مقابل الفريقين اللذين رفضا الحديث جملة ،

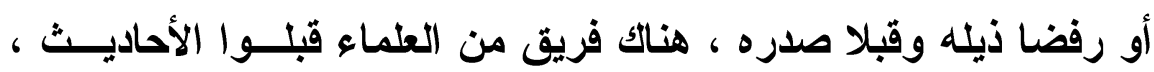

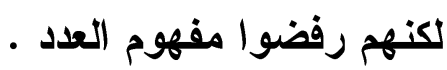
يقول الإمام ابن قيم الجوزية: (وهو الذي قد فرق السبعين بل...زادت ثُلاثا قـــول ذي البرهــان .

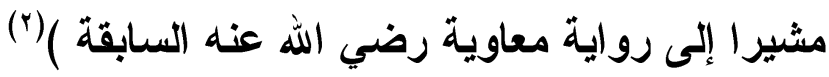

(1) العقائد العضدية تأليف "الإيجي"- عضد الدين عبدالرحمن بن أحد الإيجسي . ص . ص

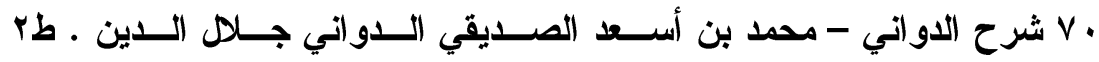

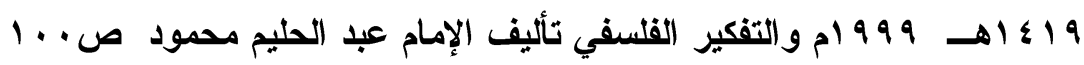

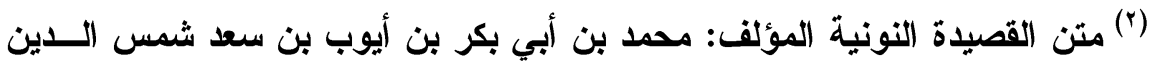

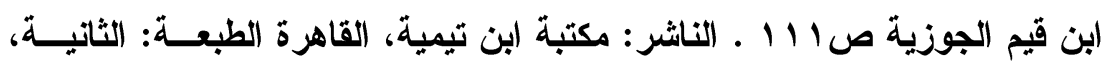


أما حجة الإسـلام ــ الغز المي ـ فقد روى الحديث بلفــ : (ســتفترق أمتي بضعا وسبعين فرقة ، كلهم في الجنة إلا الزنادقة )(') وهذه الراوية لم نجدها إلا عند حجة الإســلام ـ رحمـــه الله ـ وإذا كان الغزالي حجة في الدراية فإنه في الحديث غير متثبــث ، وقــــــــال

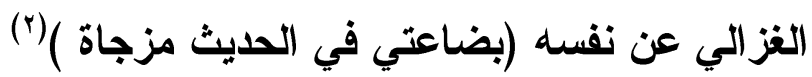
وإذن فيمكن النظر إلى أن العدد الأي ورد في الثرع في آيات عديدة

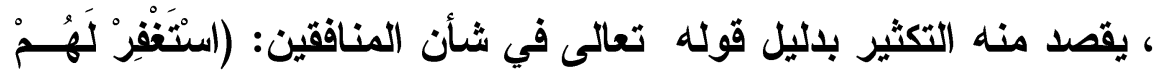

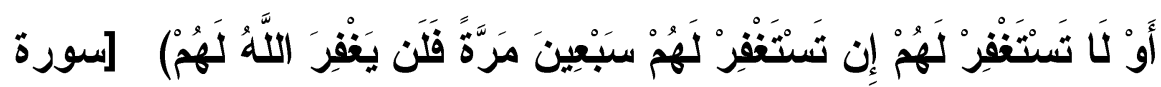

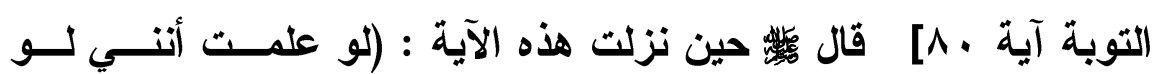

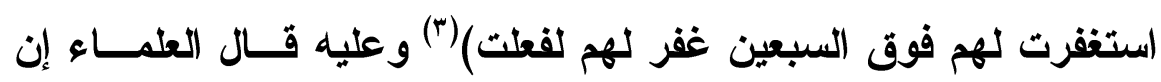

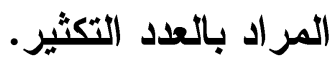<smiles>[Hg]</smiles>

(1) فيصل التفرقة بين الإسلام والكفر والزندقة ـ تأليف الغزالي الطوسي - أبو حامد الغزالي صب 9 ا - ضمن مجموعة الجواهر العو الي، تثتنمل على سبعة رســائل

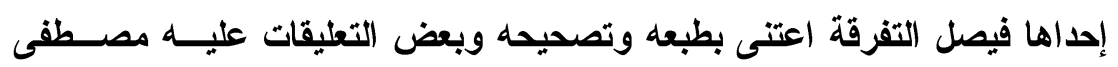

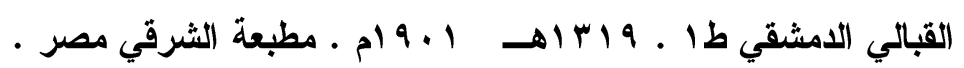

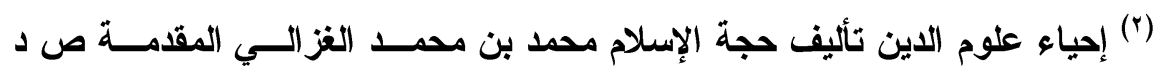

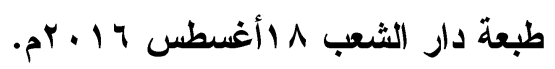

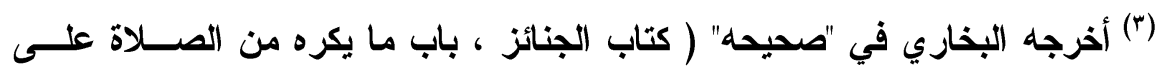

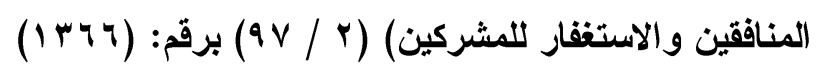




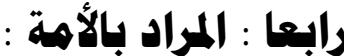

من الحق أن يقال إن الأمة تنقسم إلى :

$$
\text { rا أمة ألاعوة الإجابة }
$$

وأمة الدعوة بالنسبة لسيدنا محمد

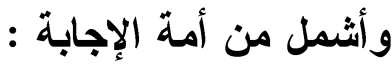

فأمة الدعوة الإسلامية هم الخلائق من الإس والجن الذين جـاء

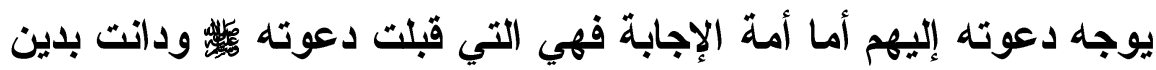

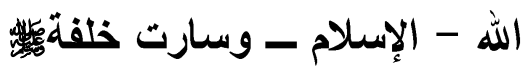

وينبغي بعد كل ما قدمناه ــ من حديث افتراق الأمة ــ أن نقــول :

(أولا نحن لانتفق مع الأين رفضوا الحديث جملة فقد عرفنا مسن أئمسـة

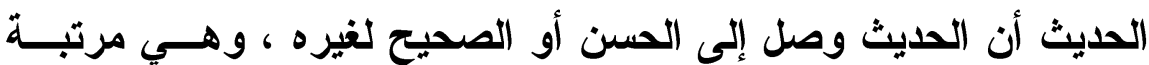

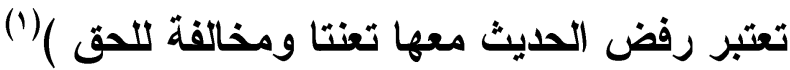

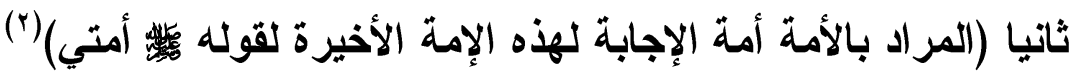

فإذا تجاوزنا هذا الجاتب من موقف العلماء من حديث افتراق الأمسـة

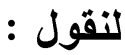

(1) الفرق الإسلامية تأليف أ. د مزروعة ص r r مدينة نصر القاهرة غــرة المحسرم $-1 \leqslant 1 r$

(†) الفرق الإسلامية تأليف أ. د مزروعة ص r r مدينة نصر القاهرة غـرة المحـرم 
هل تفرق الأهة قدر لازم وفرض هحتوم ؟

لقد فجر حديث اقتراق الأمة هذه المقابلة المأســاوية بـين دعــوة النصوص الثرعية الصريحة للأخوة والوحدة ، والتحذير مــن الفرقـة وبين تأكيده

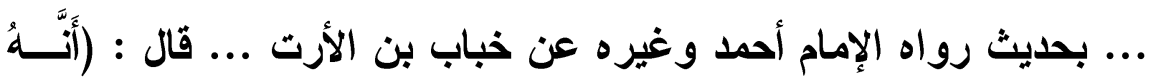

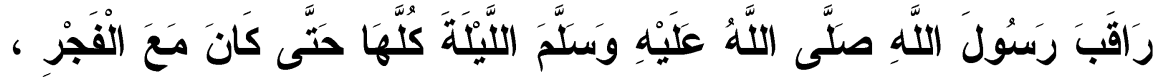

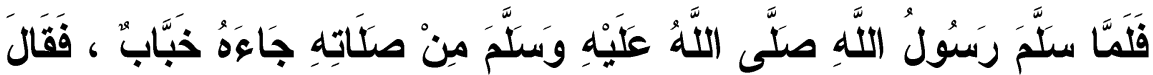

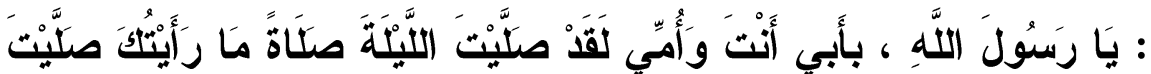

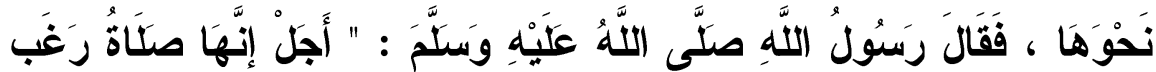

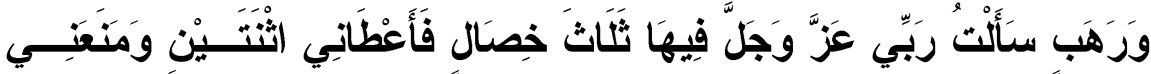

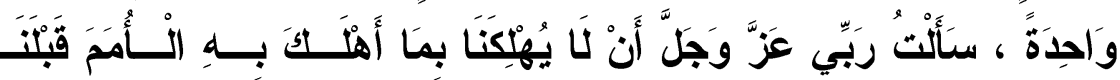

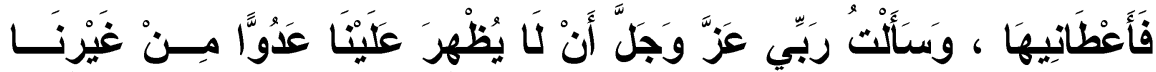

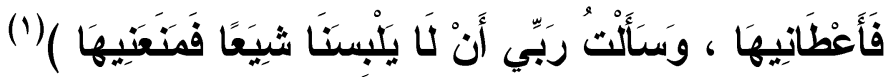
ومعني الحديث ( الأول : ألا يهلكهم بما أهلك به الأمم مــن الغــرق والريح ، والرجفة ، و إلقاء الحجارة من السماء ، وغير ذلك من أنــواع العذاب العظيم والثاتية : عدم ظهور عدو عليهم من غيرهم فيستبيح بيضتهم .

(1) أخرجه النسائي في" المجتبى "(كتاب قيام الليل وتظوع النهار، باب إحياء الليـل)

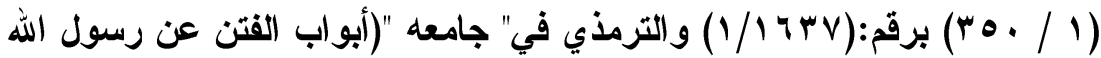
صلى الله عليه وسلم.، باب ما جاء في سؤال النبي صلى الله عليه وسلم ثلاثاً في

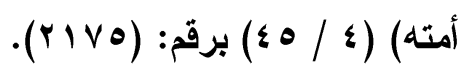


والثالثة : عدم لبسهم شيعا واللبس الاختلاط ، والاختلاف بالأهو اع،

والشيع : جمع شيعة وهي الفرقة )(1)

نحن هنا إذن مع حديث يمتلك الروئية الواضحة لتفرق الأمة، ويمتلك كذلك نقلاته كئس من خطوة إلى خطوة على طريق القبول... ولكن وقــوع التفرق بين الأمة في زمان ما، لا يعني عموم الوقوع وإلا كانت دعــوة

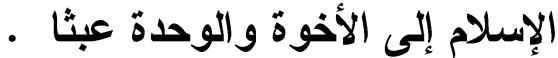

\section{أسباب الاختلاف بين المسلمهين :}

تصف أسباب الاختلاف بين المسلمين مجموعة ظـــواهر نســلاهمها من: دعوة الإسـلام إلى إعمال العقل ، طبيعة اللغــة ، ونصــفها الثــاني يعكس مجموعة آخري من طبيعـة البشــر والخــلاف حــول الخلافـة الإسلامية، ودخول غير المسلمين في الإسلام ، التعرض لبحث كثير مسن المسائل الاقيقة والغامضة ، والكلام في القصص القرآتــي ، وترجمــة العلوم غير الإسلامية إلى العربية ـ و إليك البيان في ايجاز شديد ـ أولا : دعوة الإسدلام إلى إعمال العقل، حيث نلاحظ أن القرآن الكريم جاء بلدعوة حافزة قوية لاستعمال النظر والفكر والتأمسلـل والتــدبر قــال

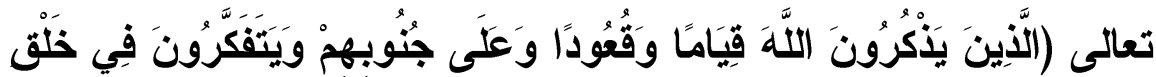

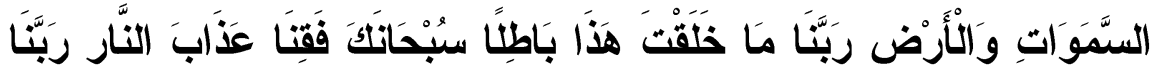

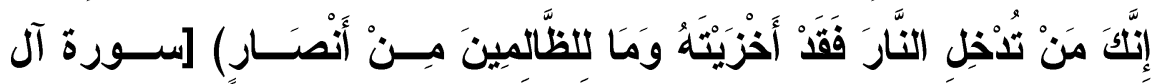

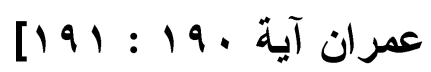

(1) مجموع فتاوي اللجنة الدائمة بالسعودية المجلد الحادي والعشرون العقيدة 
ولم يكتف بذلك بل نعى علي التقليل و المقلاين إغفــالهم لعقـــلهم ، حتي جعهم كالأنعام بل أضل ، بل توعدهم سبحانه و تعالى بالعذاب الأليم

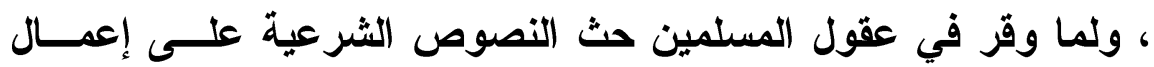

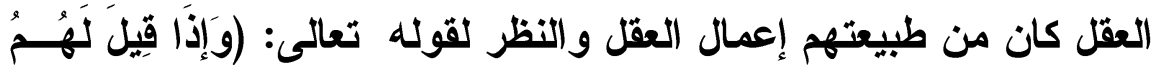

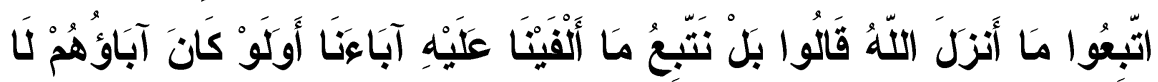

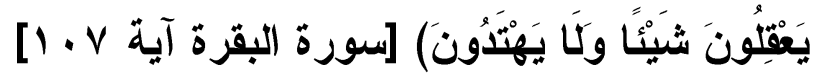

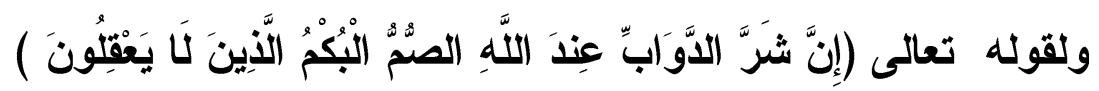

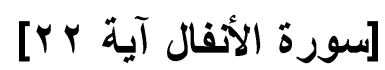

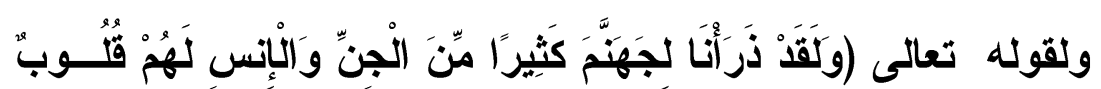

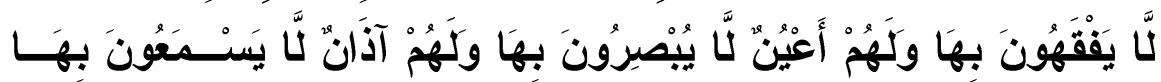

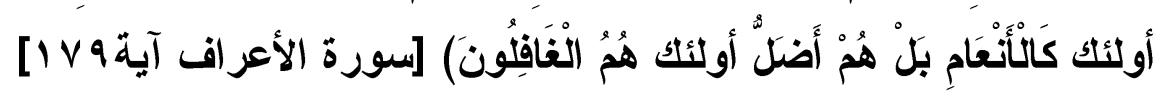

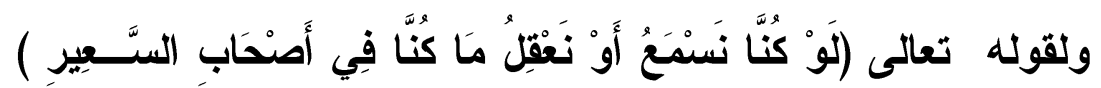

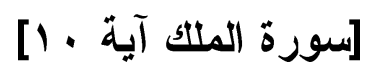

ثانيا : أثار القرآن الكريم كثيرا من القضايا الفكرية التي تركت علي التفكير ظلالا من تأثيراتها العميقة : كقضية وجوده جل وعلا وصفاته ،

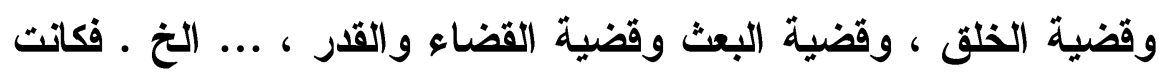

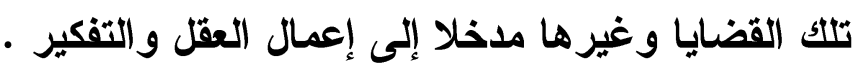

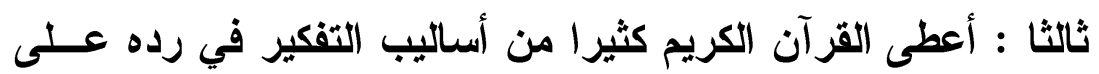

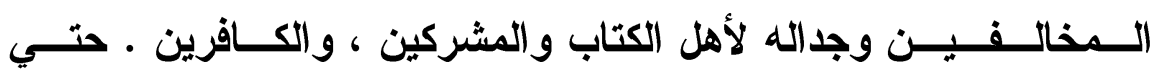

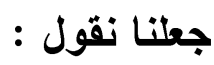


القرآن الكريم في رده متصرف في جميع فنون الفكر ، مجيد في ذلك أجمع ، وإذن فآياته الكريمة أدلة نقلية وعقلية معا .

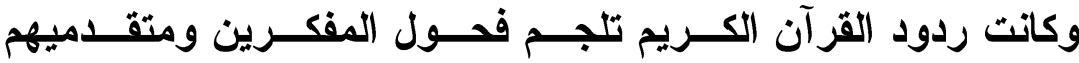

وفصحاءهم ـ في الصدر الأول ، ولكن ما لبث أن نشب الخــلاف مــرات عديدة بعد ذلك بين المسلمين وغيرهم وقد أذهلتنا العبقريات الإســلامية المقتدرة في الرد علي الخصوم و إلزامهم الحجة و إلجامهم بالأدلة .

\section{رابعا : طبيعة اللغة :}

جاء القرآن الكريم بلسان عربي مبين • وقد تميز الثـــر الجــاهلي آنذالك برشاقة الأسلوب ، وحلاوة الغــزل ، وقــوة الهجـــاء ، وعمـق الرثاء،... إلخ والمرور علي جميع آفاق البلاغة والبيان. ولكـن مــع اعتر اف القرآن الكريم للعرب بقوة الفصاحة تحداهم والقرآن الكـــيم لا

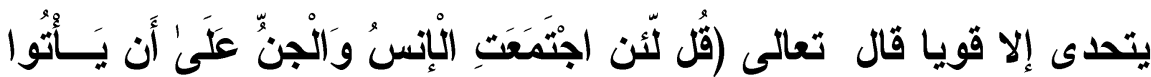

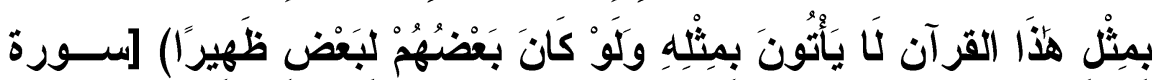

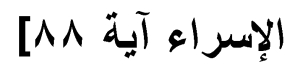

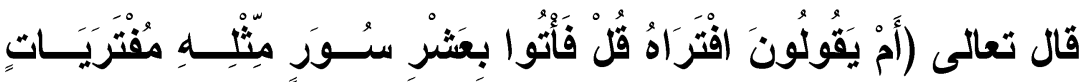

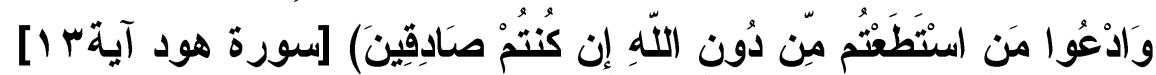

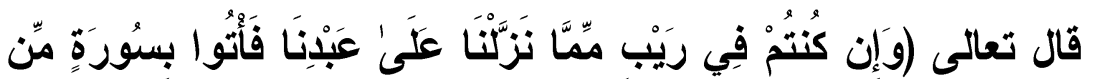

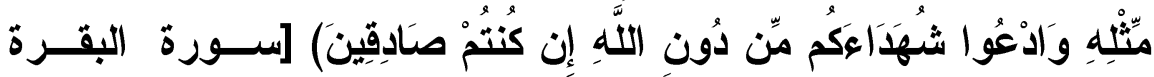

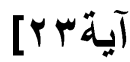

ولأن اللغة العربية فيها الحقيقــة والمجــاز ، والعـــام والخــــ ، و المطلق و المقيا ، و المنطوق والمفهوم ، والمشترك اللفظي وغيره . 
ويقفنا القرآن الكريم في وهج الاحتدام والجدل فــإذا كانــت الآيــات

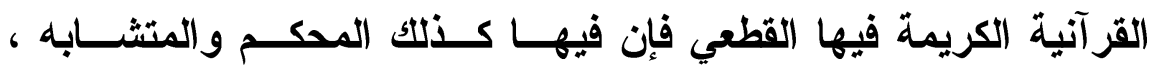
والصريح والمؤول ، والظني الدلالة و القطعي الثبوت و الدلالة، والناســـخ والمنسوخ ، والمنصوص عليه والمسكوت عنه ، وما هو محل الاجتهاد وما ليس كذلك .... إلخ

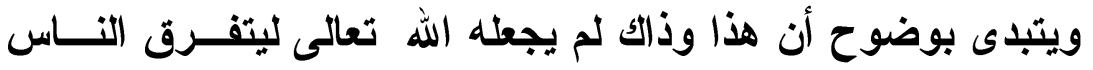
بسببه ، وقد حذرهم جل وعلا من الفرقة حتي في ظـلـل الاخــتلاف فـي سي الرأي

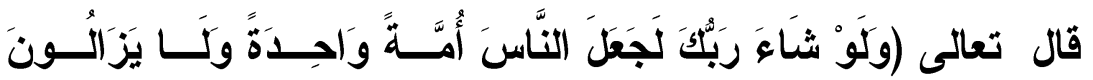

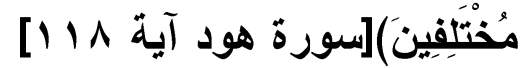
ولكن كان اختلافهم سببا في تفرقهم ! وقا جاء القرآن الكريم بكل هذا وغيره علــي نـــو مــن الثــمول والاستقصاء والتجديد ، وقد كان ذلك من الأســباب الاعاعيـة للاخــلاف والجدل حول ما تفييده النصوص القر آنية الكريمة من معان وأحكام

\section{خامسا : طبيعة البشر :}

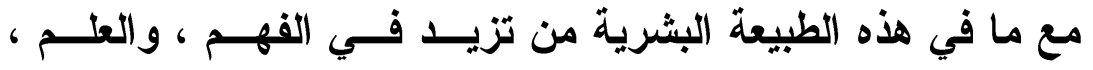
والأمزجة ، و الطباع ، والمصالح ، والأغراض ، والأهواء ... إلخ فإنه يمكن (تقسيم الناس إزاء دعوة الإسلام إلى إعمال العقل إلى ثلاث فرق : القريق الأول : حسنت نيته ، وحسن قصده وفعلــهـ ، وعلــى قـــر الطاقة أعمل عقله عن صادق نية وحسن طوية وإخلاص لله - تعالى ولرسوله 
اجتهاد ، فللمصيب منهم أجران ، وللمخطئ أجر واحد ما لم يخرج واحد

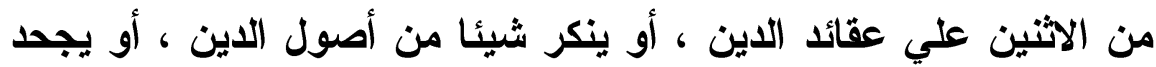

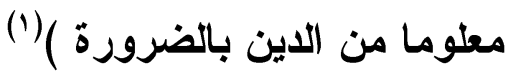
أما الفريق الثاني ( ساءت نيته ، وساء فعله ، مريض النية ســيء

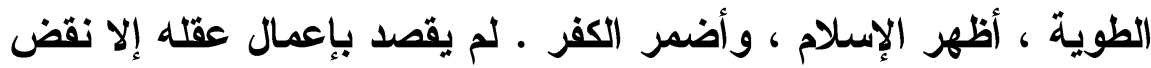

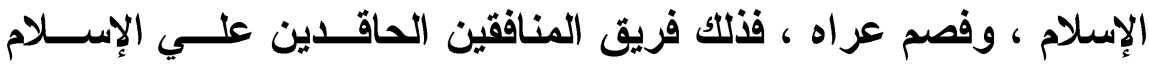

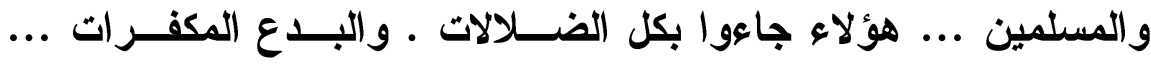

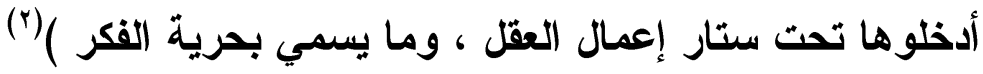

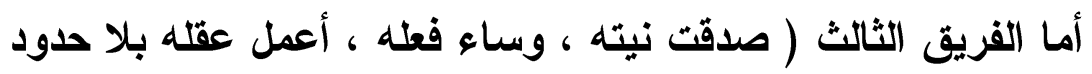

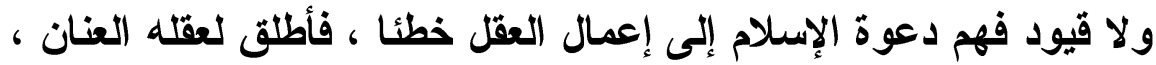

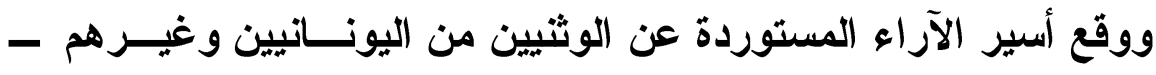

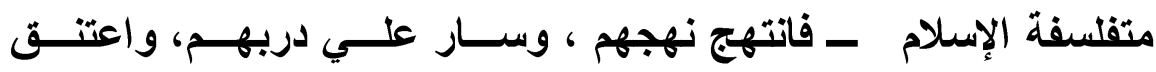

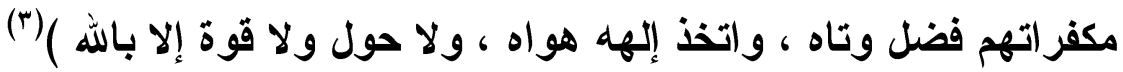
سادسا : أحداث الخلافة الإسلاهية :

يتردد النظر الفكري بين ثلاثة اتجاهات في تقويم أحسـاث الخلافــة

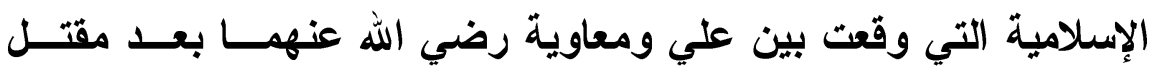
الخليفة الوقور الحيي ذي النورين "عثمان بن عفان" - الفتنة الكبرى وما حدث في الجمل ، وصفين ، والنهروان ، ومسأكة التحكيم وغير ذلك.

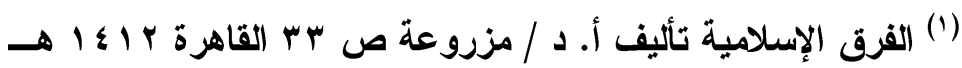

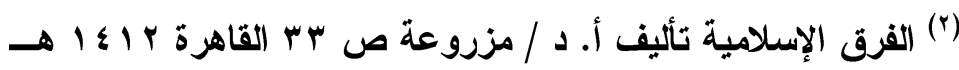

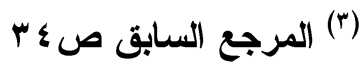


فيدعو اتجاه منها إلى أن : الحق مع علي بن أبي طالب رضي الله

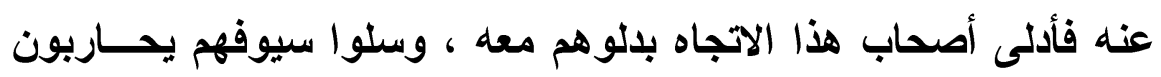
في صفه وينصرونه .

ويدعو الاتجاه الثاني : إلى أن الحق بجاتب معاوية رضي الله عنــهـ فانتظ ـ أصحاب هذا الاتجاه ـ في صفوف المحاربين معه ضد الإمسام

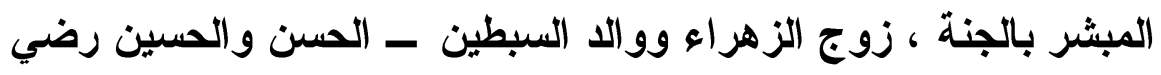

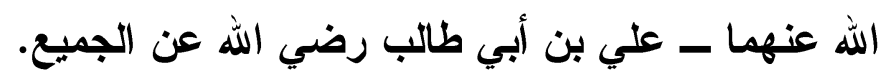
أما الاتجاه الثالث : فقد تكافأت عنده الأدلة وتساوت لاديه البـــراهين

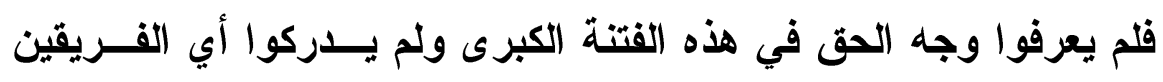
علي صواب ... فاعتزلوا الفريقين وتوقفوا عن قضية الخلافة وأرجـأوا

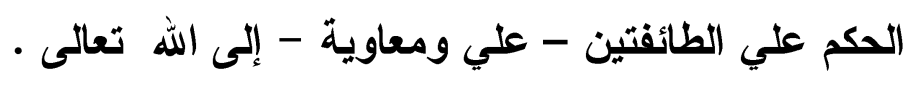

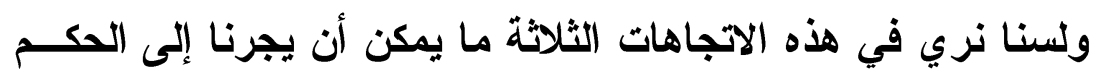

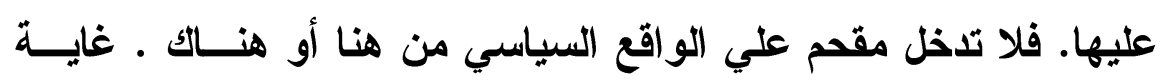

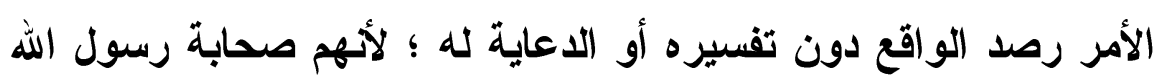
. 龆

ومهما يكن من شيء فقد ظل حديثه

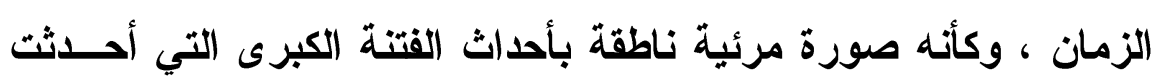

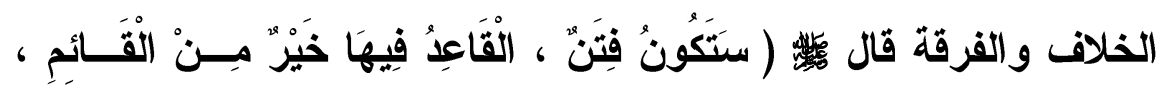




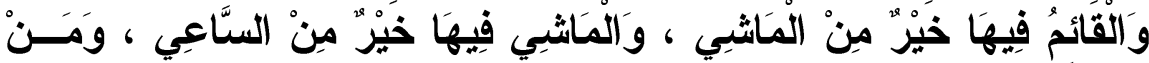

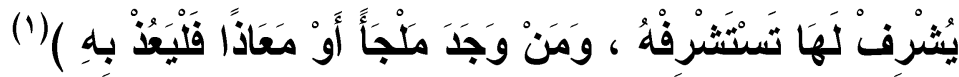

\section{سابعا : دخول غير المسلمين الإسلام :}

لماذا لا نزعم بأن البلاد التي فتحها الله تعالى علي المسلمين ودانت

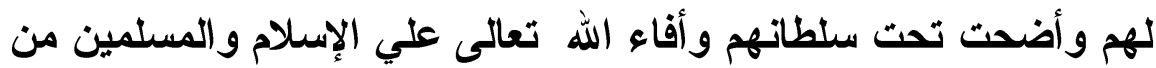
فتح هذه البلاد خيرا كثيرا ولكن كان لهذه الفتوحات خطرها الجسيم الذي

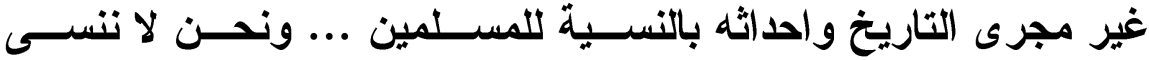

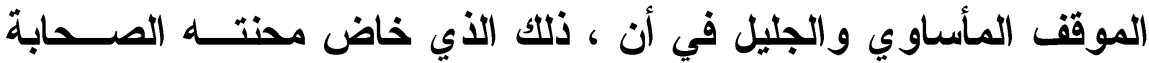
رضوان الله عليهم أجمعين حين قتل الخليفة العادل عمر بن الخطــاب "

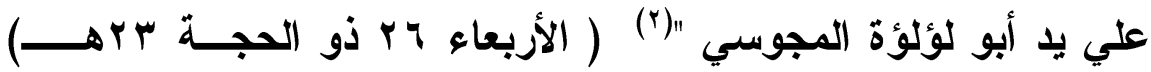

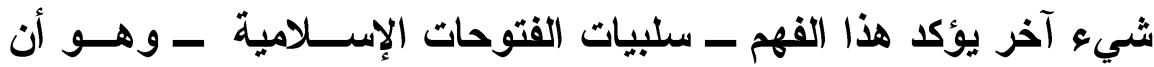

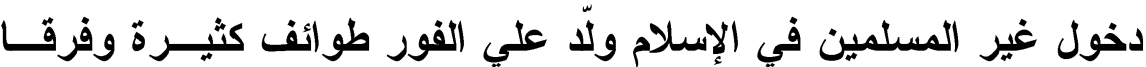

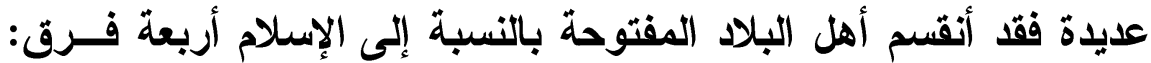

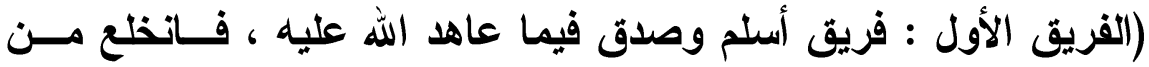

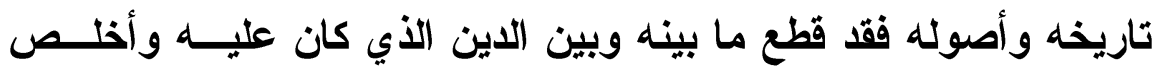
نيته لله تعالى ، فرضي الله عنهم وتحت إحساســهم بنعــة الرســالة

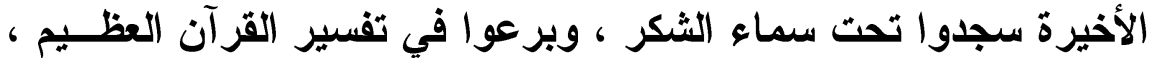

(1) أخرجه البخاري في "صحيحه" ( كتاب المناقب ، باب علامات النبوة في الإســلام)

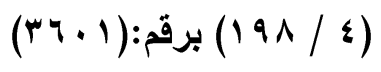

(") الفرق بين الفرق تأليف البغدادي - عبد القاهر بن طاهر بن محمد بـن عبــالله

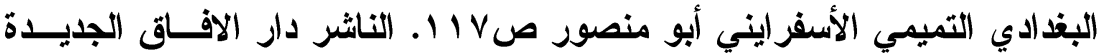


وحفظوا لنا السنة الشريفة المطهرة ـ فهم من الأعاجم الأين لا يعرفــون

غير طريق الله ـ فنفعهم الله ، ونفع بهم )(')

الفريق الثاني : ( أباح لنفسه أن يبقي علي ما كان عليه ــ دينه -

ولم يقبل الاخول في الإسدلام ، وأعلن ذلك في صراحة ووضوح ـ فهؤلاء أراحوا المسلمين من شرورهم ، وقـ تركهم المســلمون ومـــا اختــاروا

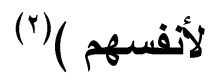

الفريق الثالث : فريق لئيم الطبع يجيد المراوغــة أظهـر الإســلام وأبطن الكفر أكل الحقد قلبه على الإسلام و المسلمين فلم يــنس حزنــــه الشاغل علي دينه الوضعي ووطنه الأي أصبح تحت إمـــارة المســلمين

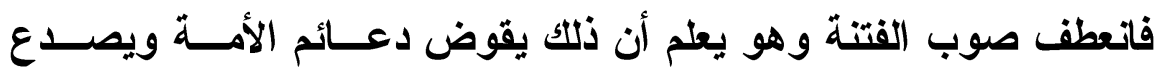
بنيانها المتين وعلي أيدي هؤلاء باتت الفتنة وأفرخت .

الفريق الرابع : كان يعاني من قضية الانشطار المتوحد - اذا جـاز

التعبير - ـ فقد اعتنق الإسلام ولم يستطع التخلص من قديم عقيلتــه ،

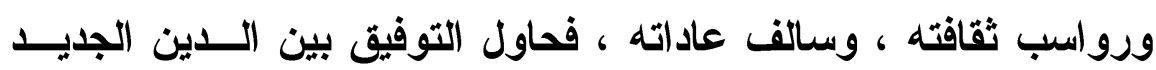

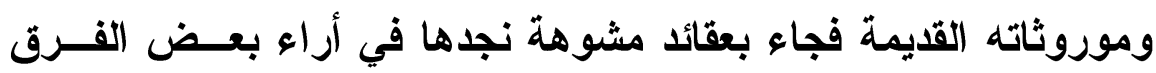
كالحلول والاتحاد وادعاء العصمة للبشر ... وإلى أخر هذه العقائد التـي

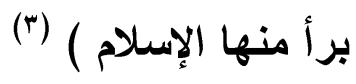

(1) (الفرق الإسلامية تأليف أ.د مزرعة ص ^^ץ بتصرف طبعة ملاينــه نصــر غـرة

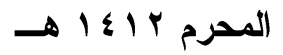

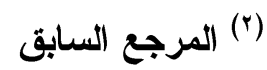

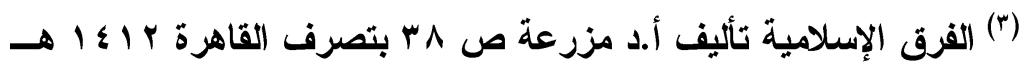


إن ذلك كله يؤكد أن عالم الفتوحات الإسلامية ليس هــو عـالم

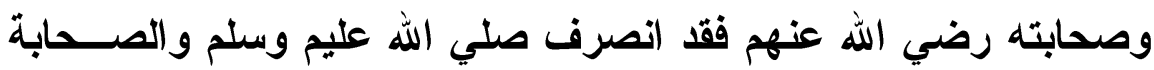
إلى القرآن والسنه فقط ، وما ذكرناه آنفا كان عالم الفتوحات الإســلامية

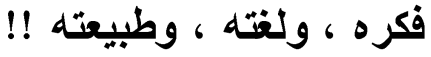

\section{ثاهنا : التعرض لبحث كثير هن المسائل الدقيقة والغاهضة :}

يتبدى بوضوح أن الفكر الإسلامي في زمن النبـي رضوان الله عليهم كان لغته القرآن الكريم والسنة المطهرة . وقد كان هذا الفكر وحيا سماويا يصافح العقل والقلب معا ، وينساب

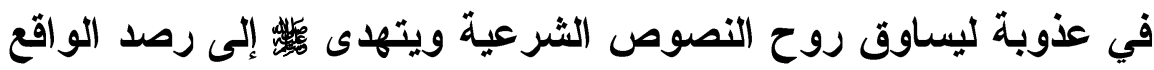
الخارجي ليحيله إلى واقع اسلامي ناطق بهوية الزمان و المكان ـ والجمال في عذوبة القرآن الكريم وتفسير السنة المطهرة له جطــه. عالم ــ السلف الصالح ـ يتخاغم شكلا ومضمونا لأن مداره كسـان قائمـــا على التطبيق لا على التظظير. ويتر افد لغة وروحا ويناء للأمة الإسلامية!! فقد بدا الفكر الإسـلامي في عهز السلف الصالح وضَحَحُ الصبح . أما بعد زمن السلف الصالح فنكاد نثفق علي أنفسنا من علم الكــلام الذي تعرض لقضايا ومسائل صعبة بل ومستفلقة الفهم علي الكثيرين من

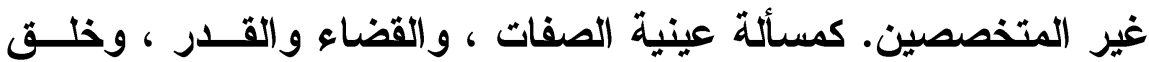
القرآن ، وشيئية المعدوم... الخ وغيرها من القضايا التي غلفت الفكـر الإسلامي بضبابية الروئية وصعوبة المصـطلحات التــي فتحست أمسام المسلمين بابا واسعا بل شاسعا من أبواب الجلدل والاختلاف؛ فعلم الكــلام 
يجري على منطق خاص بالصفوة من العلماء الأين وضح الحق عنـــهم واستبان الاليل لايهم؛ فلهذا عكف عليه العلماء فلا يحصى: كم ناظم لـهـ ومختصر، ومستدرك عليه ومختصر، ومعارض لله ومنتصر.

\section{تاسعا : الإسرائيليات :}

فطن علماء الأمة الإسلامية لوقوع كثير من الإسرائيليات في التفسير

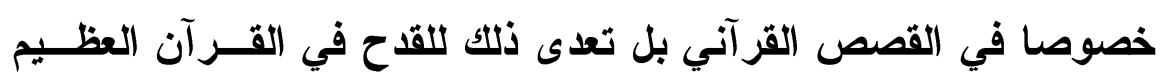
والنيل من الرسول الكريم فقد أحال الوضاع تفسيرها علي النحل المحرفة والحمل والافتراء ، وكاتت الاسرائيليات مادة خصبة للاختلاف والجــل حول الصحيح منها وغير الصحيح ، وما هو من الإسلام وما ليس مسن الإسلام في شيء ولأن الإسر ائيليات عديدة فسنكتفي هنا بذكر مثالين

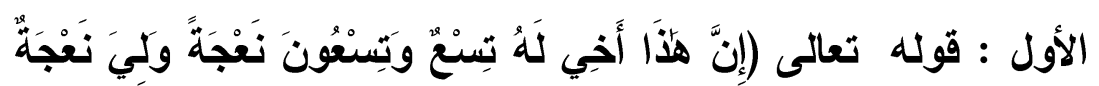

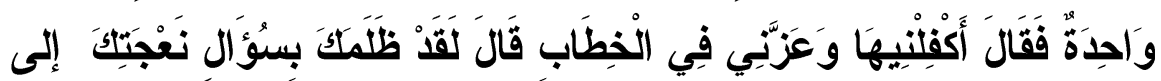

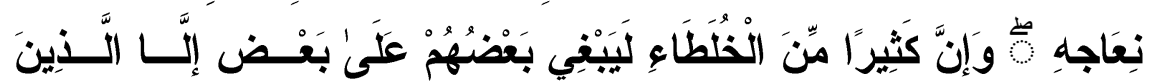

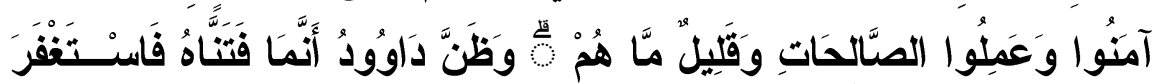

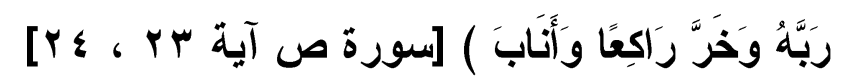

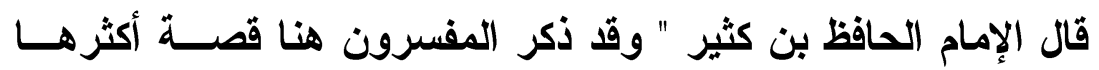

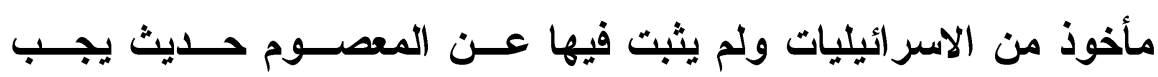
(تباعه" (1)

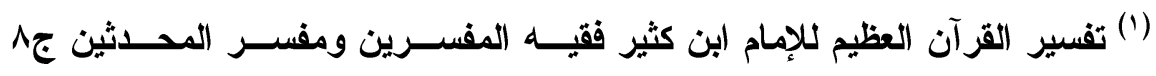

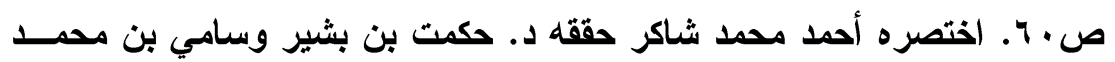

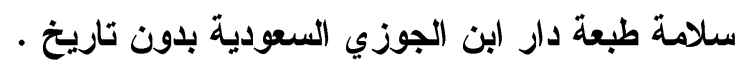


" وقد كان كثير من المفسرين يذكرون في هذه القصة أثياء لا تليق بنبي من أنبياء الله عز وجل قصصا إسرائيلية تقتضي القدح في الأبياء فيجب على المرء أن يحترز منها ولا يقصها على أحد إلا مبينا بطلانها " ذكروا لاواود عليه السلام تسع وتسعين امرأة وأنه شغف حبا بامرأة

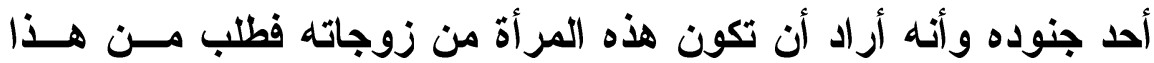
الجندي أن يذهب إلى الغزو لعله يقتل فيخلف امرأته ثم يأخذها داود عليه

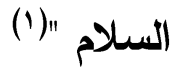
وبدهي أن هذه القصة مختلقة فهي بلا شك كذب لا يليق بأنبياء الله تعالى ولكن هذه من أخبار بني إسرائيل الكاذبة التي لا يجوز لنــا نـــن المسلمين أن نعتمدها أو نقصها إلا للتدليل على الإسرائيليات وعلى بيان

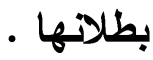

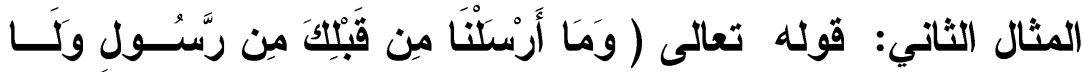

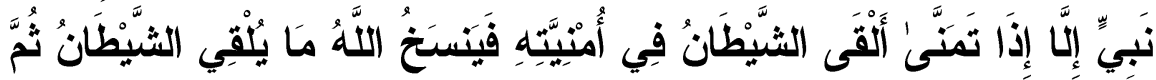

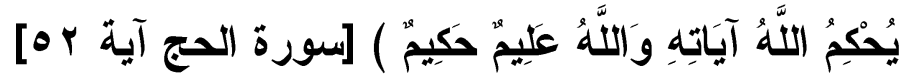
والتفسير الخاطئ للآية يتضح مـن الإســر ائيليات التــي تقــول إن الثيطان ألقى في قراعة الرسول الوثوق بالقر آن الكريم وبالرسول

(1) معالم التنزيل في تفسير القرآن الكريم "تفسير البغوي" تأليف: محيي السنة - ابو محمد الحسين بن مسعود بن محمد بن الفــراء البغــوي الثــافعي جه ص الآ.

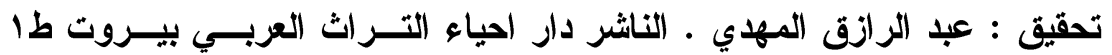


وفي شرح هذه الثبهة وتلافي هذا السوء يقول الإمام ابـن كثيــر

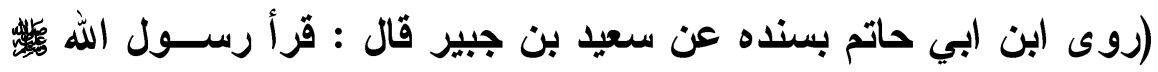

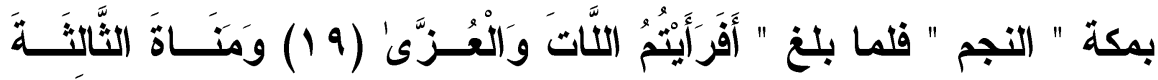

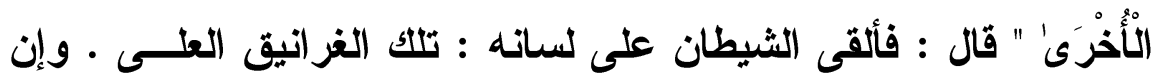

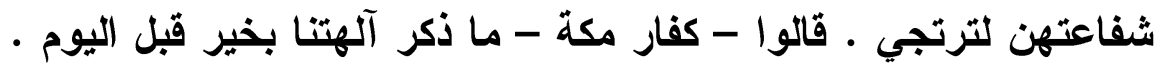

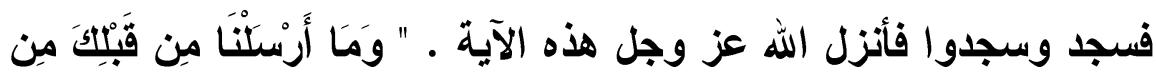

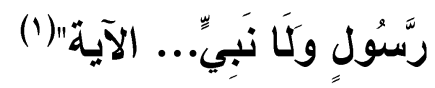

وذكر الإمام ابن كثير في تفسيره رواية أخرى " رواها البـز ار فــي

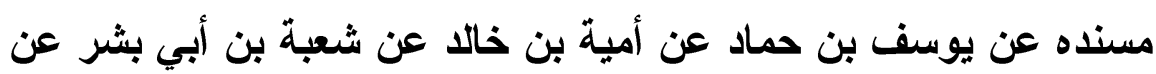

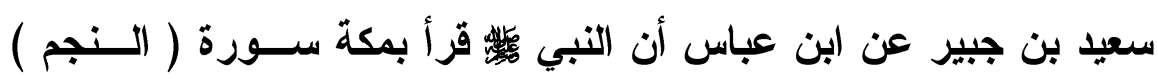

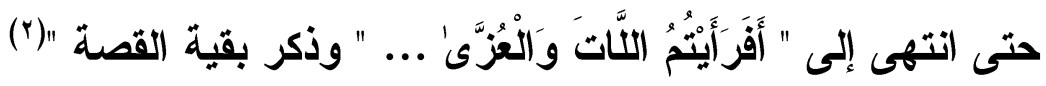

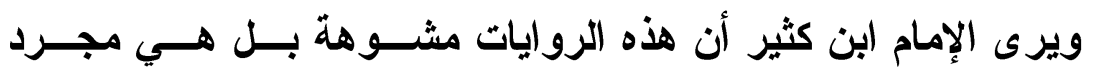

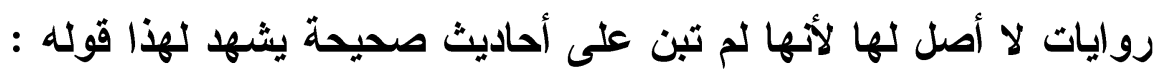

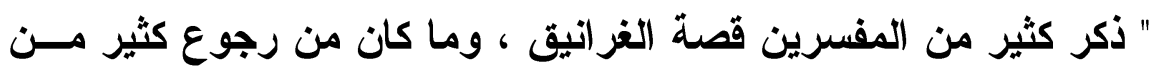

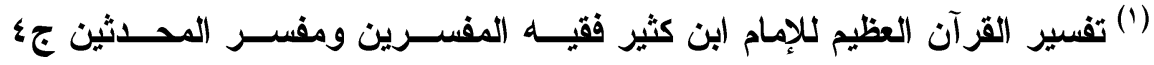

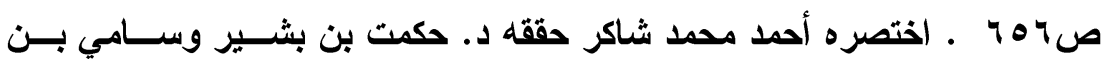
محمد سلامة طبعة دار ابن الجوزي السعودية بدون تاريخ

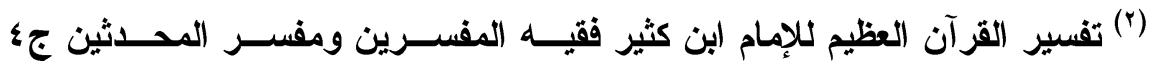
. 
المهاجرة إلى أرض العبثة ظنا منهم أن مشركي قـريش قــــــــــــا

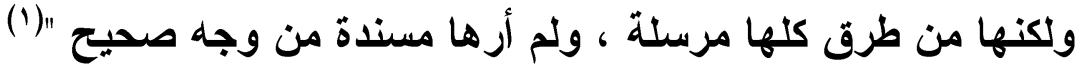

و إذا أردنا أن نلخص موقف العلماء من حديث الغرانيق في سـطور قليلة فخلاصته الواضحة هي ما قاله " القسطلاني في شرح البخـاري : وقد طعن في هذه القصة وسندها غير واحد من الأيمة حتى قـــال ابــن فئن

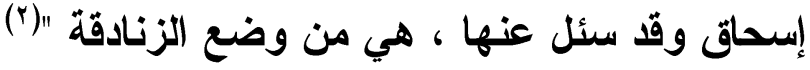
ويرفض القاضي عياض حديث الغرانيق في قوله " إن هذا حليث لم

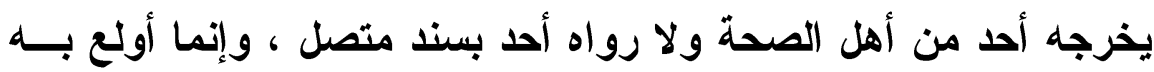

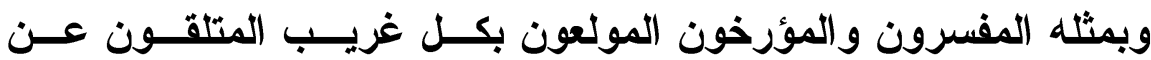
الصحف كل صحيح وسقيم • ونقل عن أبي بكـر بـن العربــي الإمسـام

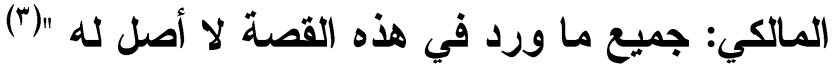
وموضع القبول عندهم في هذه القضية مـــا " رواه البخــاري فــي

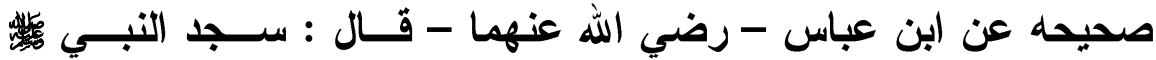
بالنجم وسجد معه المسلمون و المشركون و الجن والإس "عيائ وروى أيضا البخاري بسنده عن عبد الله بـن مســود قــال : أول

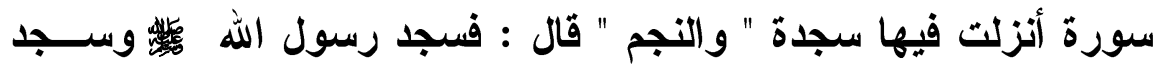

(1) تفسير القرآن العظيم للإمام ابن كثير فقيـهـه المفسـرين ومفسـر الحـــثين جr

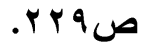

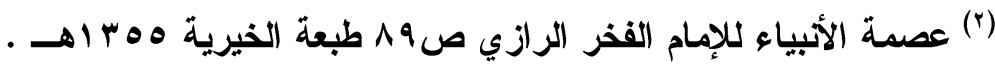

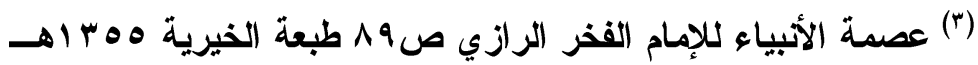


من خلفه إلا رجل رأيته أخذ كفا من ثراب ، فسجد عليه ، فرأيته بعد ذلك

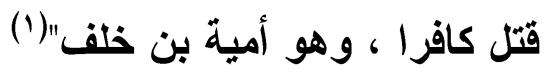

ولكي ندرك أبعاد المعنى وأغواره في هذه الآية الكريمة (وَمَا أَرْنَتْنَا

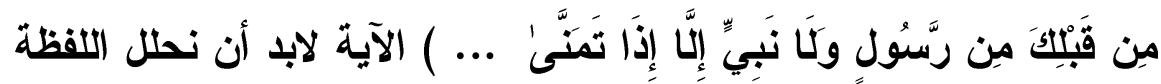

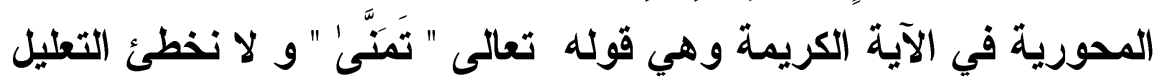

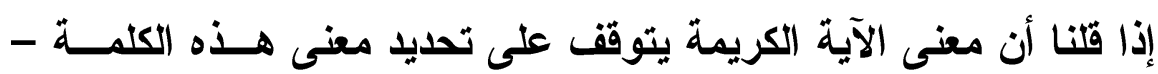

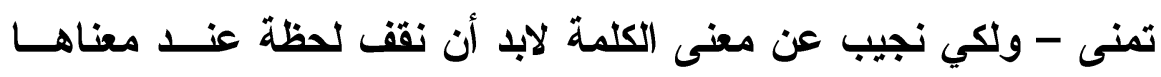
اللغوي ( فقد جاعت الكلمة في اللغة لأمرين : أحدهما : حــديث الــنفس

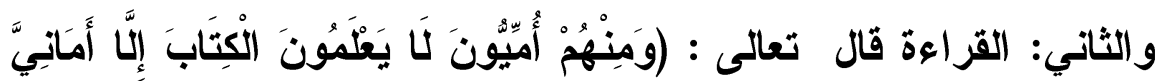

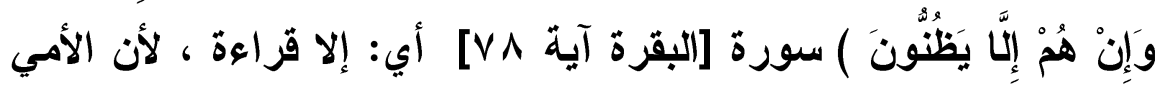
لا يعلم القرآن من المصحف وإنما يعلمه قراعة .

فعلى أن التمني هو حديث النفس ، والملقي شيطان الجن يكون معنى

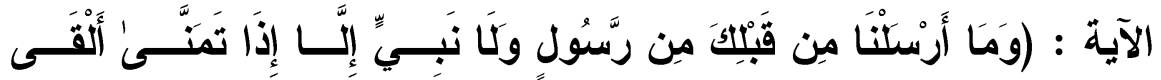

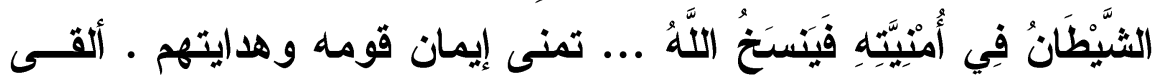
الشيطان إلى أوليائه شبها فينسخ الله تعالى تلثك الشبه ويحكــم الآيــات

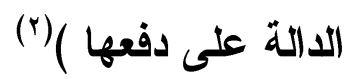

(1) أخرجه البخاري في "صحيحه" ( أبواب سجود القرآن ، باب ما جاء فــي ســود

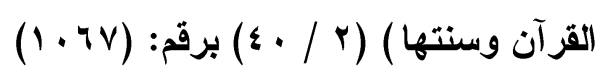

(ז) روح المعاني في تفسير القرآن العظيم والسبع المثاني "تفسير الألوسي" تــأليف:

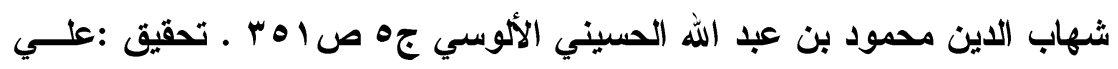

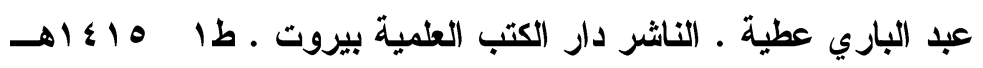


وهذا التفسير هو ما أعتقده وأقول به لأنه يقتــع العقـلـل وأحكامــهـ

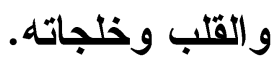

لكن الأمر الأي يثير الاهشة ما ذهب إليه بعض الأثمة من المفسرين

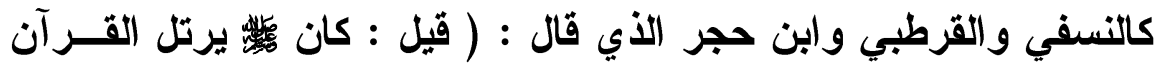
الكريم ، فارتصده الشيطان في سكتة من السكتات ونطق بتلك الكلمــات

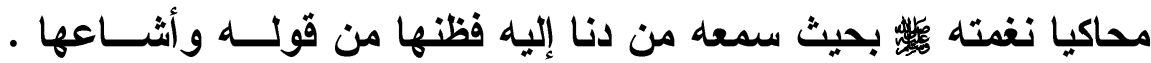
قال: وهذا أحسن الوجوه )(')

ودافع الإمام القرطبي عن هذا الرأي - بعد أن حكــاه - بقولـــهـ : "

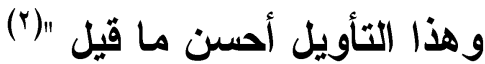

والإمام النسفي ينتصر لهذا الرأي بل يقدم لنا الاليل عـــى إمكانــهـ

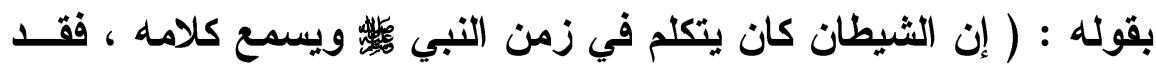

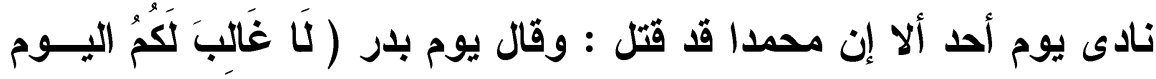

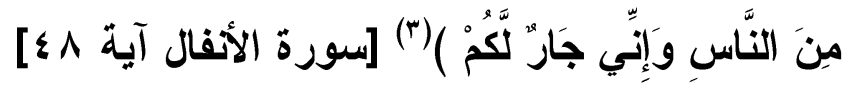

(1) روح المعاني في تفسير القرآن العظيم والسبع المثاني "تفسير الألوسي" تـأليف:

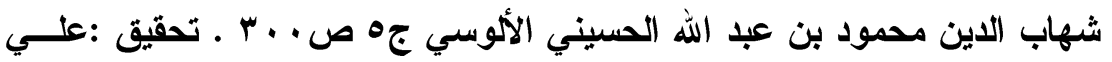

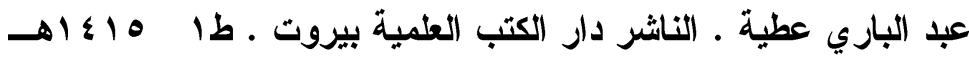
(ץ) الجامع لأحكام القرآن ( تفسير القرطبي ) ـ المؤلف : محمد بن أحمد الأنصــاري

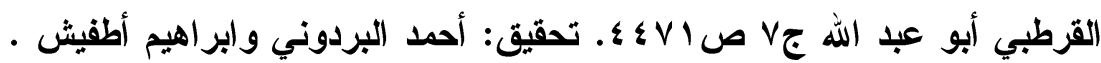

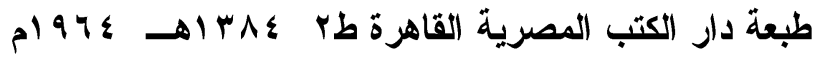

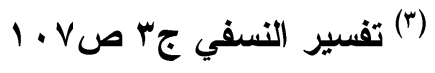


واتجه الإمام النسفي لتفسير الآية الكريمة تفسـيرا منطقيــا يتفــق والقول بعصمة كتاب الله العظيم ورسوله الكريم فيقول : ينسخ الله تعالى ما يلقى الشيطان ، يذهب به ويبطله ، ويخبر أنه الشيطان ثم يحكـم الله آياته ، ويثبتها ويحفظها من لحوق الزيادة من الثيطان "والله عليم" بما أوحى إلى نبيه وبقصد الثيطان " حكيم " لا يدعه حتى يكثفه ويزيله "(() وبالرغم من أن أقوال الأثمة - ابن حجر ، والنسفي ، والقرطبـي ،

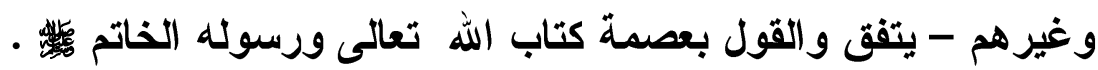
لكن هذا الرأي لا نميل إليه بل نعرض عنه ولا نقره لأمسـور نـــكر منها: 1- عدم ثبوت صحة حديث الغرانيق كما بينا آنفا . r- أن السياق الأي وضعت فيه الآية الكريمة يوجهها وجهة مغايرة لقول الأثمة ابن حجر ، والنسفي ، والقرطبي ، فنرى أن " التمني " فـي

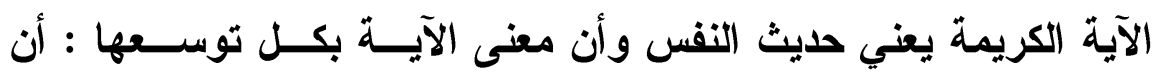

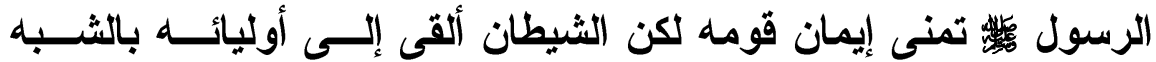
للتشكيك في آيات الله فأزال الله تلك الشبه وأظهر دينه تعالى على أيدي رسله . لألك فإن كل ما يمكن فرضه من آراء في تفسير هذه الآية غير

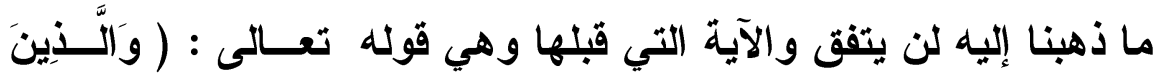

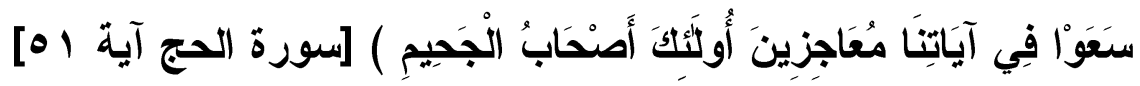

(1) تفسير النسفي تأليف: الإمام الجليل العلامة، ابي البركات عبداله بن أحمد محمود

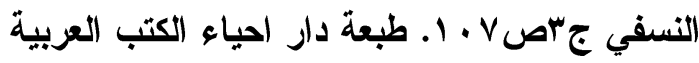


r- ما ذهب إليه الفخر الرازي في قوله : " إن إحكام الآيات بإزالة ما يلقيه الثيطان عن الرسول أقوى من نسخه لهذه الآيات التــي تبة آتـي الثبهة معها ، فإذا أراد الله إحكام الآيات لئلا يلتبس ما ليس قرآنا بقرآن

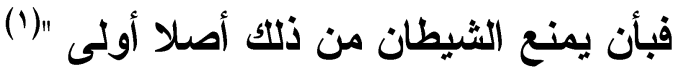
ع - لا يوجد عقل سليم يقول إن النبي

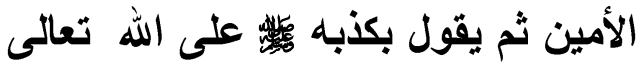

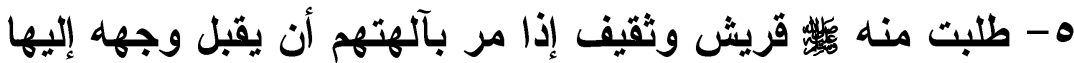

ووعدوه بالإيمان إن فعل ذلك فما فعل ، ولا كان ليفعل (r) ويبقى أن نقول : إنتا بعد أن دخلنا في تفاصيل وجزئيات القضية الغرانيق - وجدناها تجرؤاً من الطاعنين للقدح في القرآن العظيم والنيل من الرسول الكريم

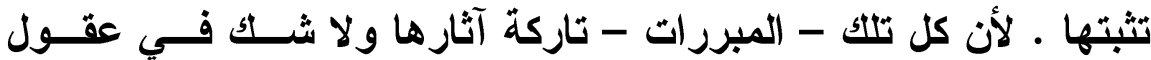

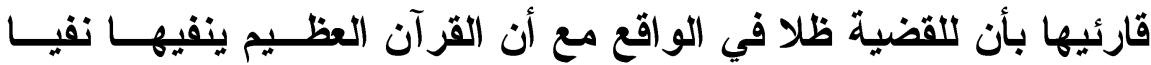

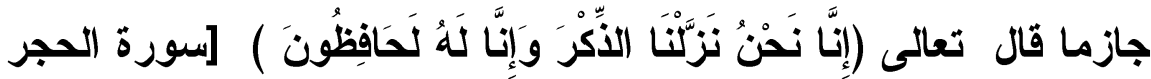

(')مفاتيح الغيب أو التفسير الكبير ـ تأليف "فخر الاين الرازي" - أبو عبد الله محمــ بن عمر بن الحسن بن الحسين التيمي الرازي جף صـ 19 ـ الناشر دار احيــاء

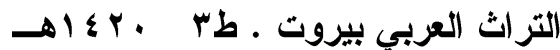
(ץ) (الجامع لأحكام القرآن ( تفسير القرطبي ) ـ المؤلف : محمد بن أحمد الأنصـاري

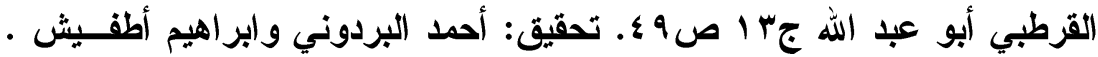

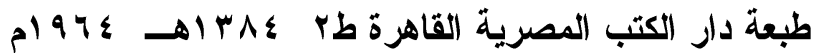


وهذا هو البرهان الأكبر على حفظ الله تعالى للقرآن العظيم من أي

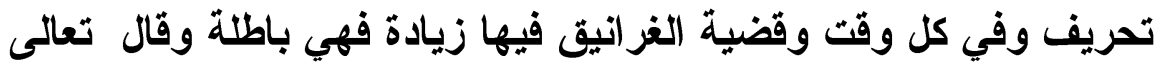

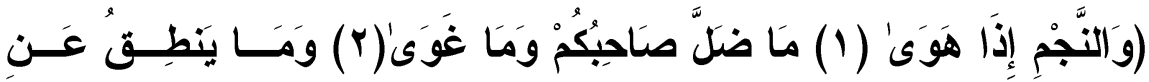

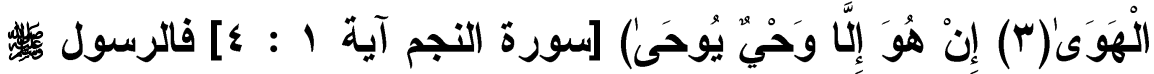

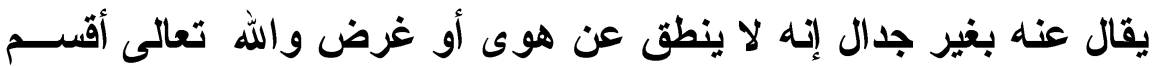

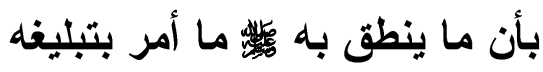

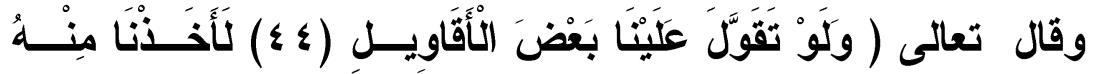

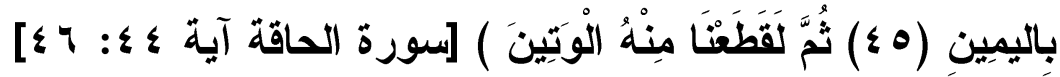
قال الإمام ابن كثير : لو كان محمد علينا فزاد في الرسالة ، أو نقص منها ، أو قال شيئا من عنــــ نفســـهـ

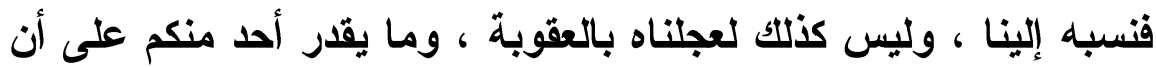

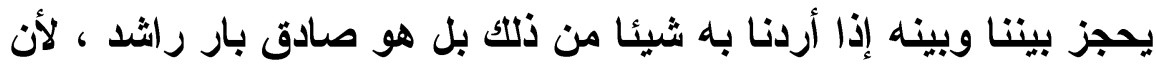

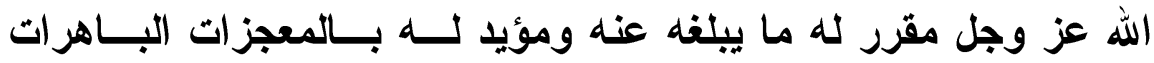
و الالالات القاطعات "((')

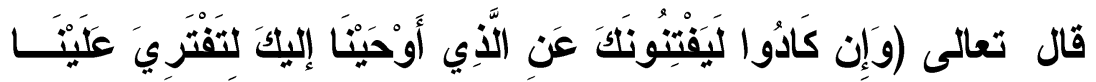

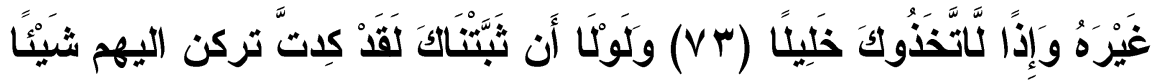

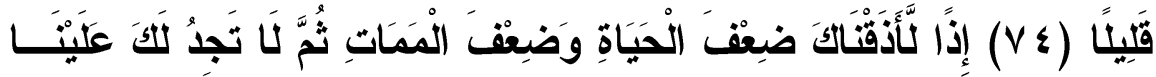

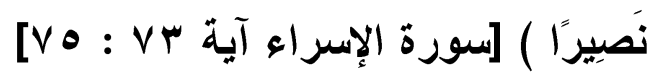

(1) تفسير القرآن العظيم للإمام ابن كثير فقيه المفسرين ومفسر المحدثين اختصــره

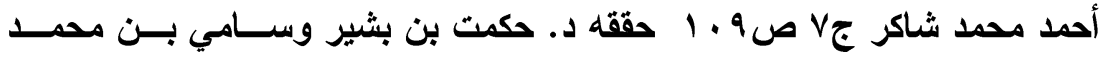
سلامة طبعة دار ابن الجوزي السعودية بدون تاريخ 
والآيات القر آنية تفيد في دقة ووضوح أن الرسول - الكفار - ولو فعل لأذاقه الله ضعف الحياة وضعف الممات ، لكـن الله

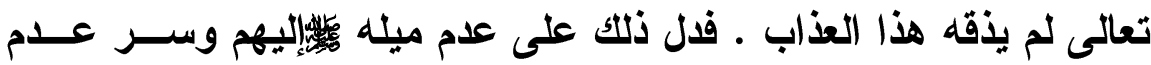

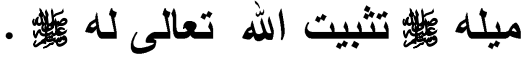

يقول الإمام القرطبي : إن الله تعالى عصمه من أن يفترى ، وثُبتـهـ حتى لم يركن إليهم قليلا فكيف كثيرا ، وهم يرون في أخبارهم الواهيــة

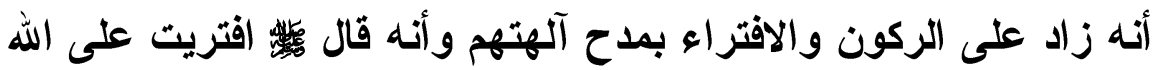

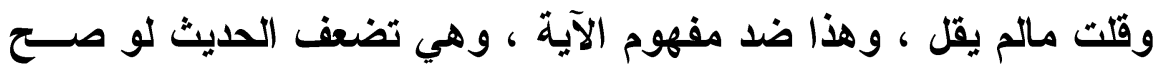

فكيف ولا صحة له "(1)

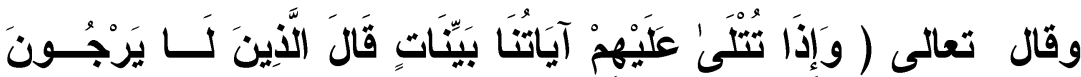

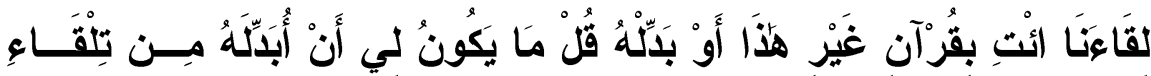

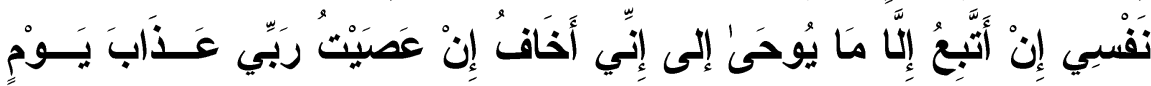

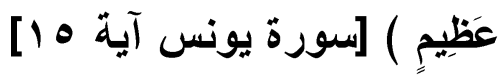

وموقف الإمام الواحدي من تفسير هذه الآيات - وهو موقف يسايره

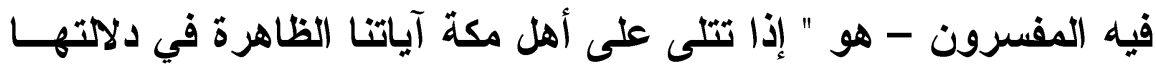

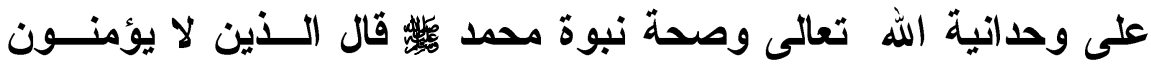
بالبعث ائت بقرآن ليس فيه ذم آلهتنا ، أو بلدل منه ما نكره ، وائت بغيره

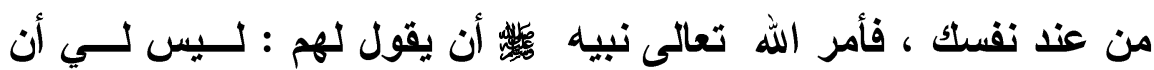

(1) الجامع لأحكام القرآن ( تفسير القرطبي ) ـ المؤلف : محمد بن أحمد الأتصساري

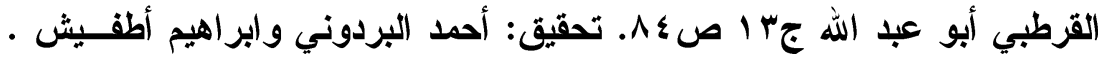

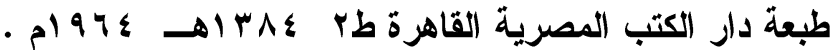




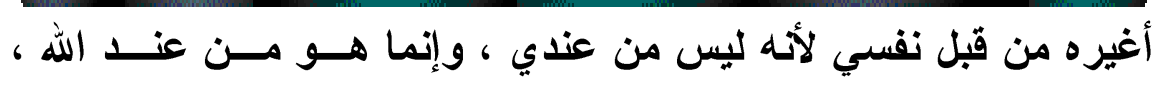

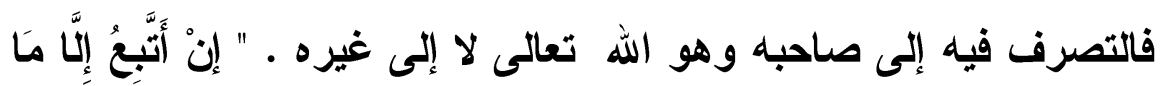

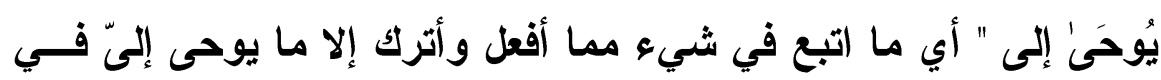

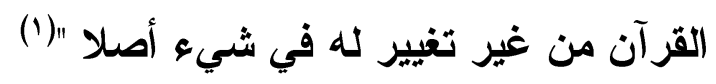

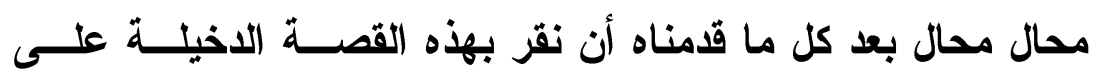

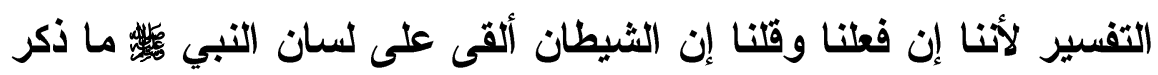

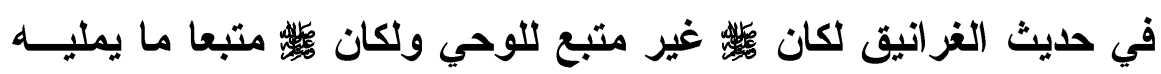

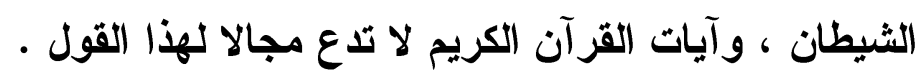

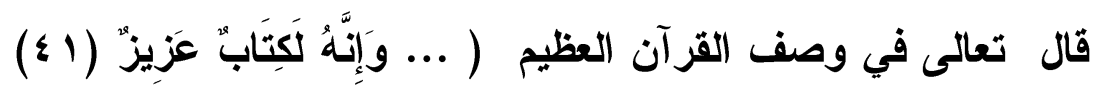

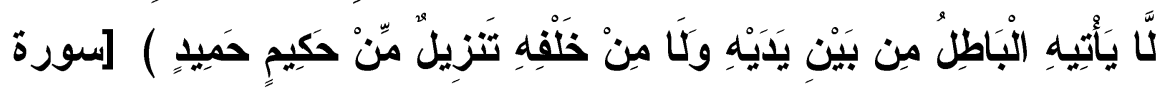

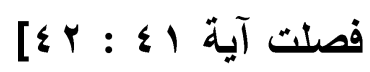

عاشرا : ترجمة العلوم غير الإسلامية إلى العربية: حيث يمكن النظر

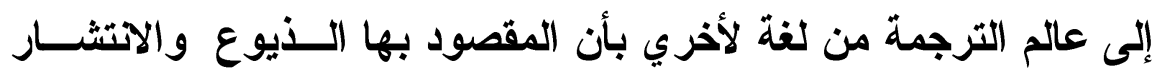

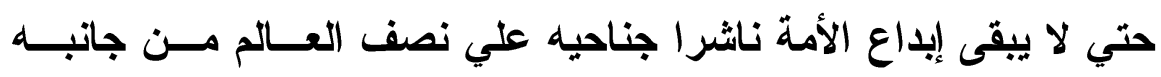

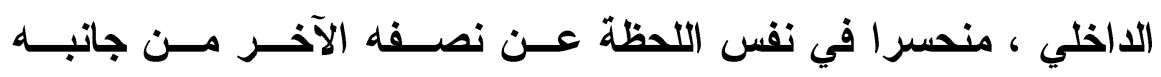

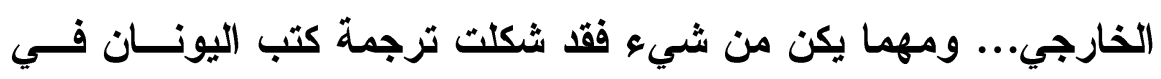

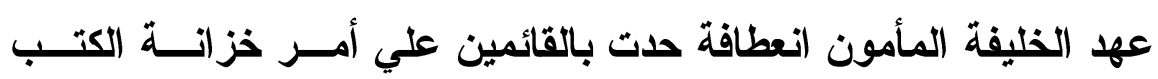

(1) الوجيز في تفسير القرآن العزيز للواحدي جا صغ جسب المؤلف: أبسو الحسـن

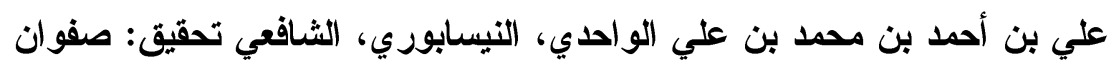

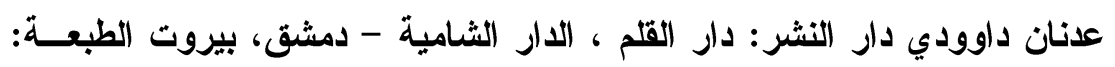

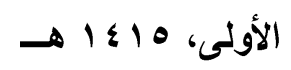


بالاتجاه إلى طريق التمرد فقد كان سوء التية مجدولا مع حسن النقل منذ البداء يؤكد ذلك الثيخ مصطفي عبد الرازق في قوله (كتب الفلاسفة التي نقلت للمأمون من جزيرة قبرص وذللك أن المأمون لما هادن صاحب هذه الجزيرة ، أرسل إليه بطلب خزانة كتب اليونان ، وكانت مجموعة عندهم في بيت لا يظهر عليها أحد أبدا ـ فجمع صاحب هذه الجزيــرة بطانتــه وذوي الرأي واستشارهم في حمل الخزانة إلى المأمون فكلهــم أثـــاروا بعدم الموافقة إلا مطر انا واحدا قال : الرأي أن تعجل بإنفاذها إليه ، فمــــا دخلت هذه العلوم العقلية علي دولة شرعية إلا أفسدتها وأوقعــ بــين

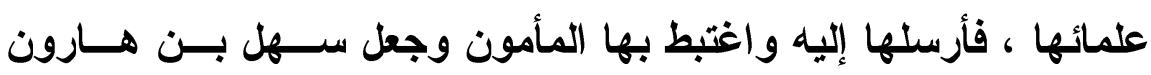

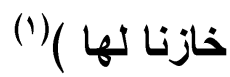

وتأثر علماء الإسلام بالقلسفة اليونانية بل حــاولوا "التوفيـق" (†) أو التلفيق بينها وبين الإسلام ، كل ذلك أدى إلى جدل عنيف بـين فلاســة الإسـلام أو علي الأدق متقلسفة الإسـلام وغيرهم من الفقهاء والمدــثـين

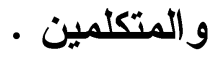

(1) تمهيد لتاريخ الفلسفة الإسلامية ـ تأليف : الثيخ مصطفى عبــدالرازق ص ؟ ؟ـ. تقديم محمد حلمي عبدالوهاب ـ طبعة دار الكتاب المصــري - القــاهرة - ودار

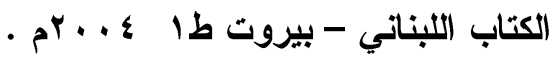

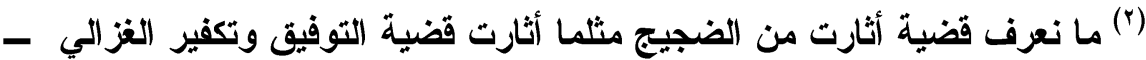

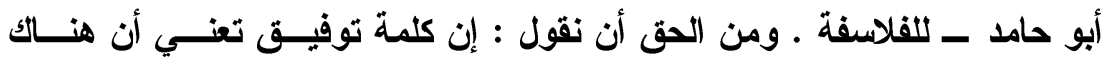

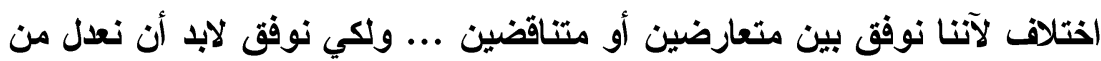

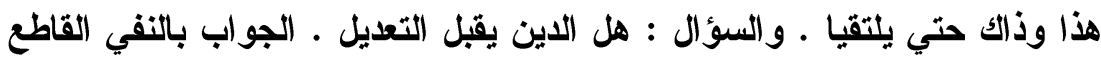

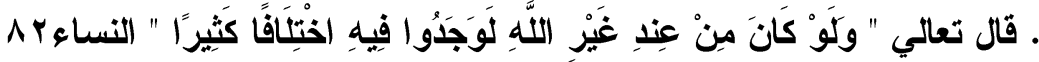


ولعله قد بات واضحا أن الاختلاف بين المسلمين قد جاء معظمه من

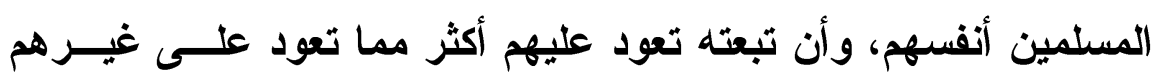

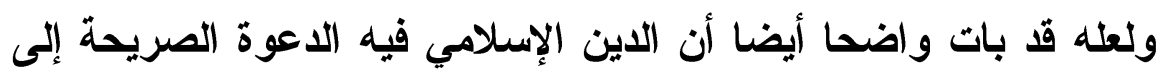

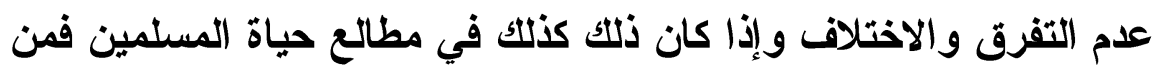

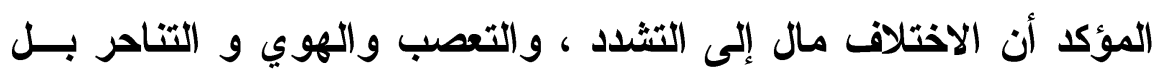

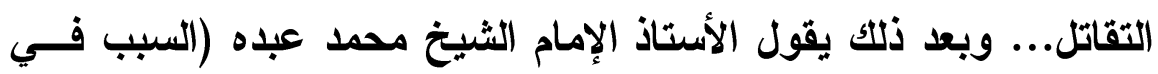

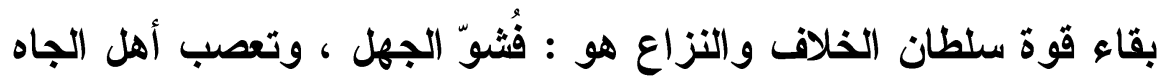

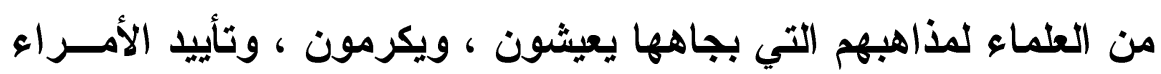

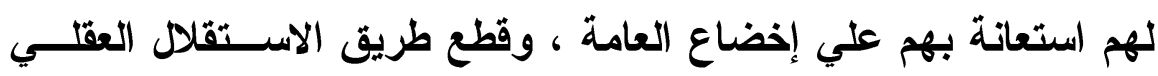

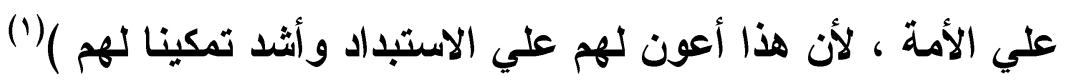
وقد كان الإمام الغزالي مفكرا واعيا لعلم الكلام والفلسفة ، حتى ترك

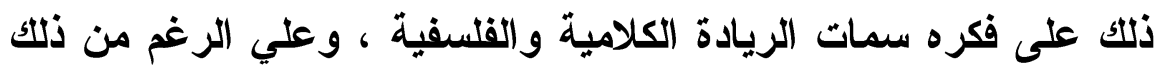

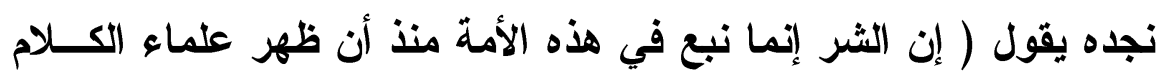

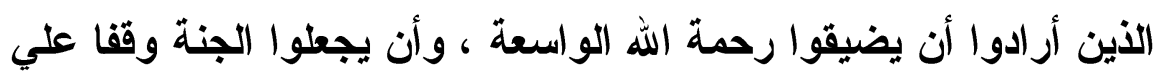

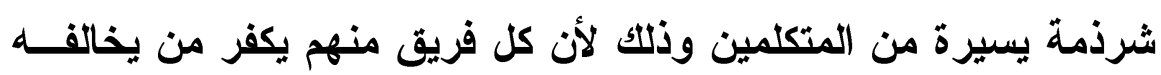

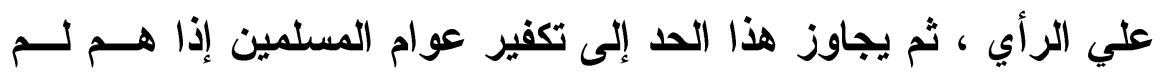

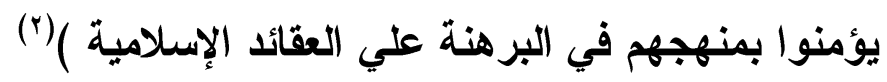

('اتفسير القرآن الحكيم ( تفسير المنار ) تأليف : محمد رشيد بن علي رضا بن محمد بهاء

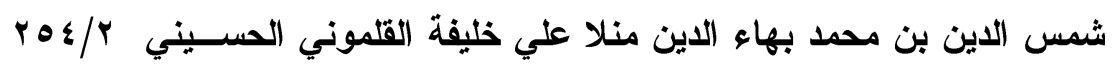

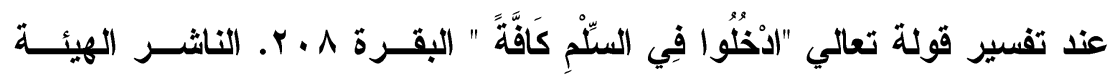

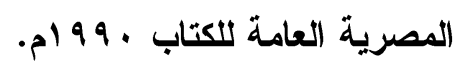
(") مقدمة كتاب فيصل التفرقة للإمام الغزاب الي المقدمة ص ج . 


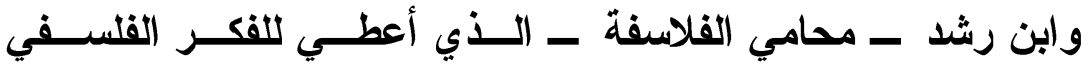

و الكلامي من جهده و إلحاحه الكثير يرى أن ( العبب في تفــرق هـــه

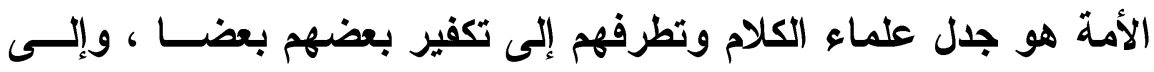
تقليد شيوخهم ، وتعطيل عقولهم ، حتي انصرفت كل فرقة إلى اللجــاج و الجدل ـ و التظاهر بالمعرفة ، ولو كان ذلك علي حساب التفكير السليم ، والثريعة (الحقة ) والجنال وإذا كان علماء الكلام والفلسفة قد اختلفــوا فــي مـــي التــزامهم العقدي، فرموا بعضا بالمروق من الدين و التثــكيك و التكفيـر ، ودفــعـع بعضهم عن بعض هذه التهم وأحالو ا فكرهم في هذا الصدد إلــى العامــة الأين حملوه علي الحمل والافتراء . وبداءً لابد من تأكيد أنتا في الفكر الإسلاهي نحتـــاج إلــى معرفــة

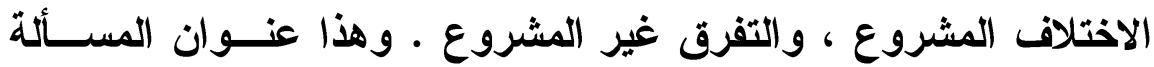

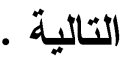

\section{الاختلاف المشروع . والتفرق غير المشروع :}

يبدو الفرق شاسعا وكبيرا بين الاختلاف المشروع ... و التفرق غير المشروع... وهو ما فطن إليه علماء الأمة ... وتظلى عنه كثيــر مسن لهن المتعصبين ... ولكن هذا لا يطمس الحقائق التالية :

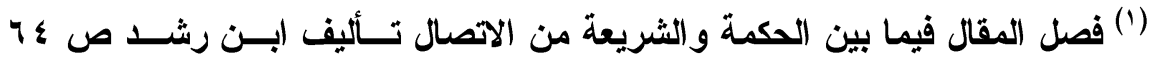

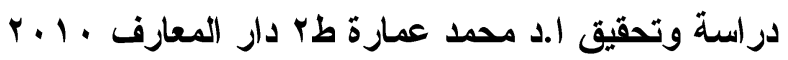


أولا : الاختلاف المشروع سنة الله في خلقه ولــن تجـــ لســــة الله

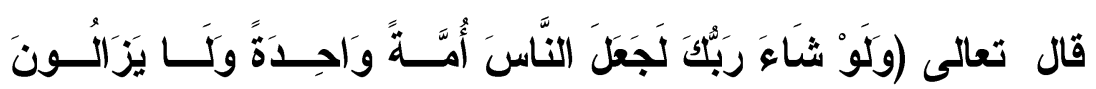

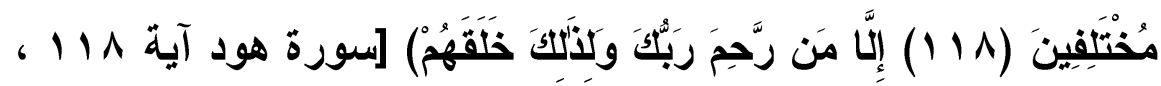

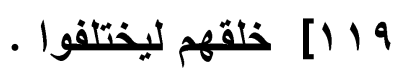

ثانيا : يمكن أن نلاحظ ليس علي البشرية وحدها بـل علــي المـلأ

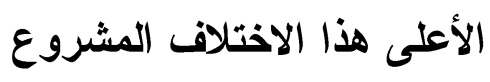
ورحم الله القائل :

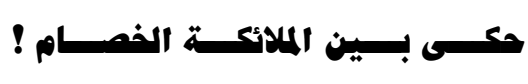

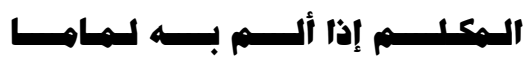

وعبـل مـــاحب الـــر الصــراما

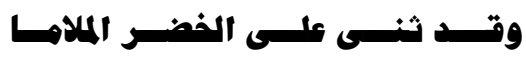

الكسرام فيسـه خسالفت الكرامسا

العـلـوم هنــا نتمسا أو تمسامسا()
تسل عسن السونساق نسربنا تـــ

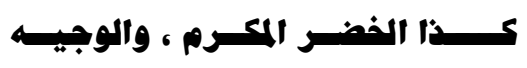
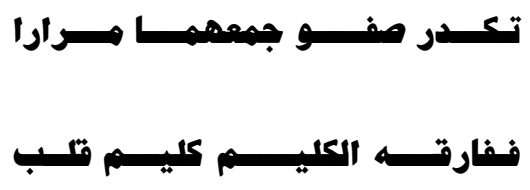

فــل علـى اتســاع الأهسر فيمسا

ومسا سبب الخــلاف سـوى اتسـاع

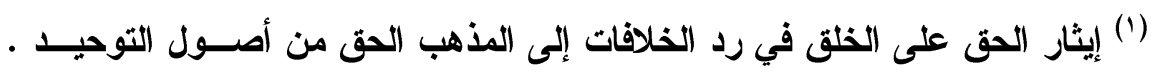

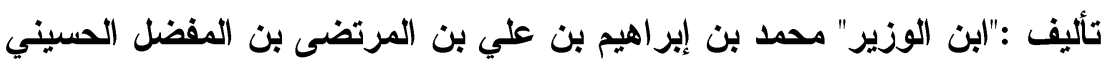

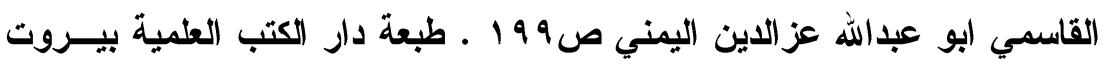

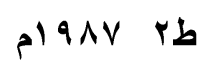


ثالثا : الاختلاف المشروع هو ما يحسب للعلماء بلا جدال ... ومــا

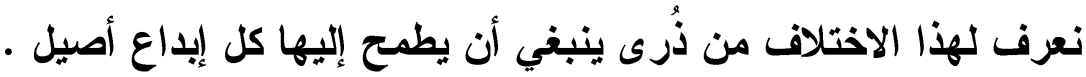
و إذن فمناط التفوق في الفكر الإسلامي هو الاختلاف المشروع • و إذا

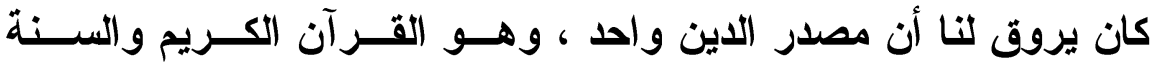
المطهرة ، ولكن هذا المصدر الواحد منه :

أ : ما يجب القطع به لوروده في نصوص محكمة لا تقبل صرفا ولا تأويلا ، ولا تحتمل جدلا ولا مراء ب : وما يجب الإيمان به مما ليس للعقل فيه مجال كالإيمان بالقضايا الغيبية

جـ : ما هو محل للنظر ، ومجال للاجتهاد ولولا هذا الأخير لـــهب

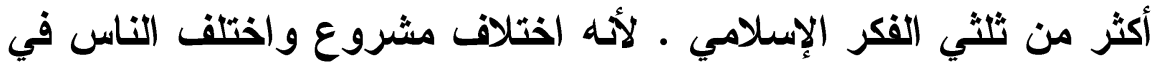

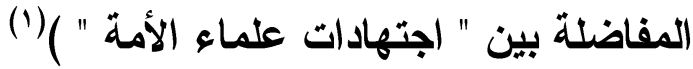
وأدرك المنصفون أن هذا الاختلاف ـ محل النظر والاجتهاد ـ هــو مقصود الشريعة : لما فيه من التنوع والتجديد وحفـز الهمــم للبحــث و الاجتهاد وهناك في مجال الاجتهاد قضية توقف عندها الفكر طويلا و هي

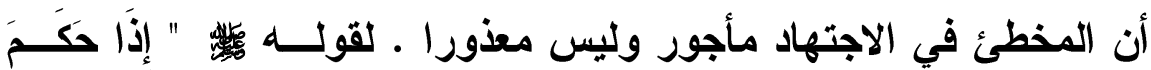

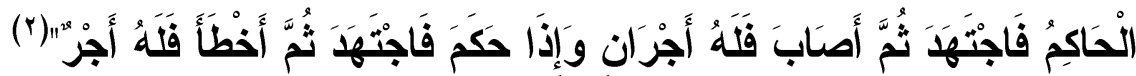

(1) والسؤال هل يجوز التلفيق بين المذاهب الفقهية والجواب : نعم متي رجحت الأدلة

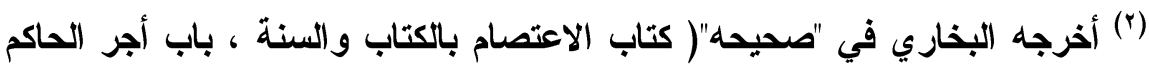

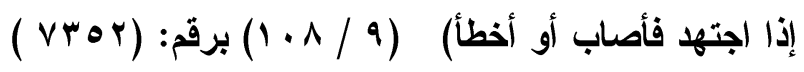


ولعلنا نرجع ذلك إلى الاتعتاق من أسر التقليــــ فــإذا تــوفر للعــالم

مسوغات الاجتهاد فليكن ملتزما أخلاقيا ودينيا بما تريد النصوص وبمسـا تطيق بل إنه كئد أقر الاختلاف في الفهم والاجتهاد بالر أي ما لم يكن فيـهـ ثم نص صريح غير محتمل من الثرع كما ورد عن معاذ رضي الله عنه حين أرسلها

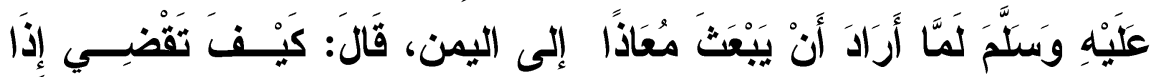

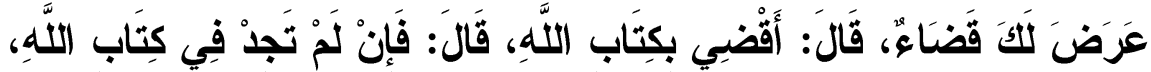

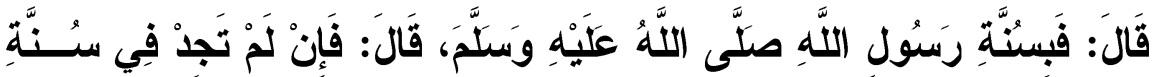

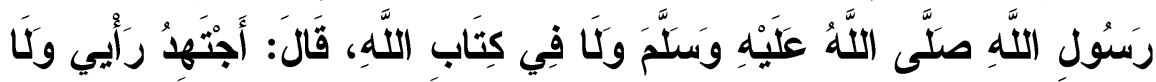

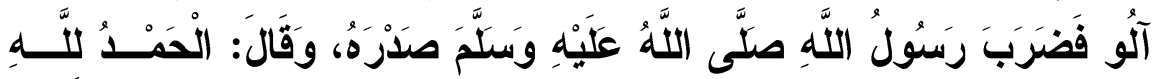

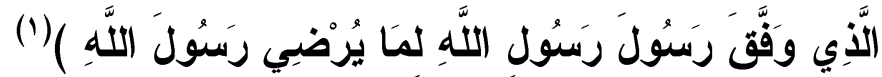
(وأقر النبي (أس : من صلي صلاة العصر في الطريق إلى بني قريظه بعد النهي عنه... كما أقر من أخر الصلاة حتي فاتته امتثالا لأمر رسول إلئي

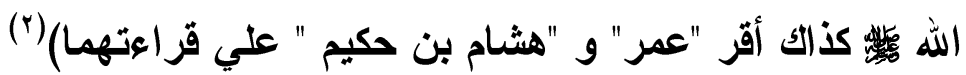

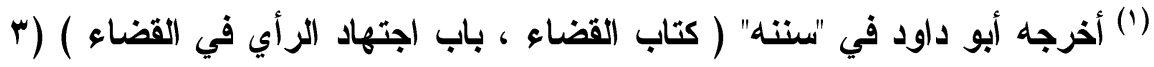

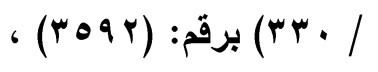

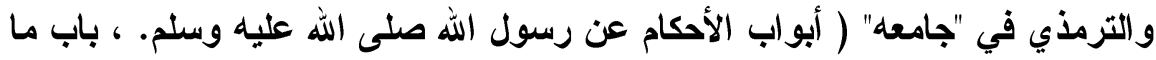

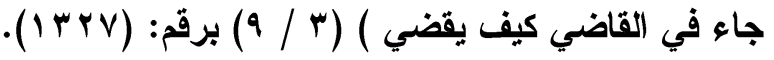

$$
\begin{aligned}
& \text { (r) }
\end{aligned}
$$

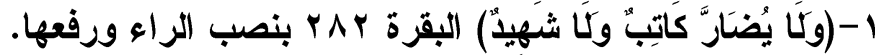

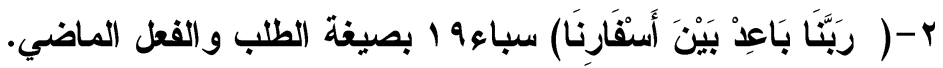


وأيضا ( أقر

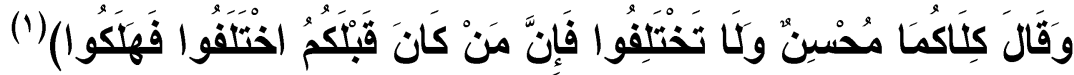

ويقف العلامة النابه " ابن الوزير " أمام هذا الاخــتلاف المشــروع ليقول ( حذرهم الئ من الاختلاف بعد الحكم بإحسانهما في ذلك الاختلاف؛ لأن الاختلاف المدذر منه غير الاختلاف المحسن به منها .

فالمدزر منه : هو الاختلاف الأي يؤدي إلى التناقض ، والتعسادي ،

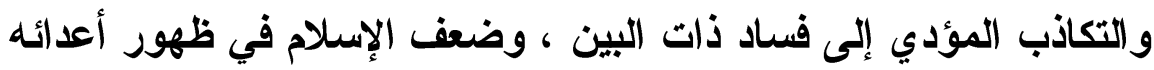

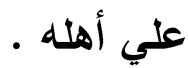

و المحسن : هو عمل كل أحلا بما علم ، مع عدم المعاداة لمخالفــة ،

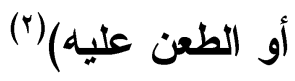

\section{$=$}

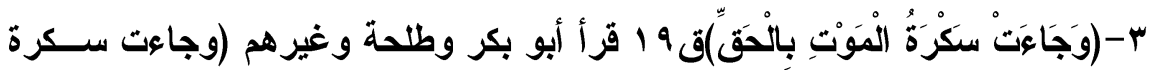

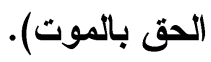

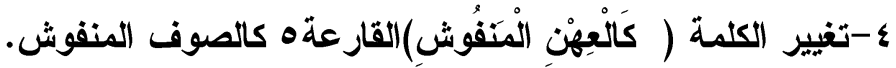

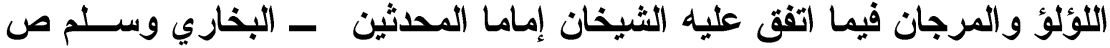

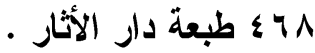

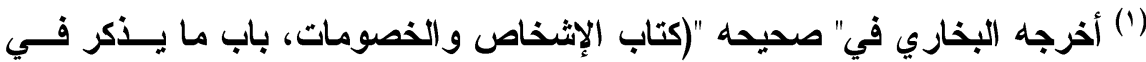

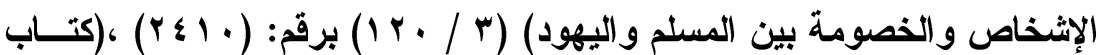

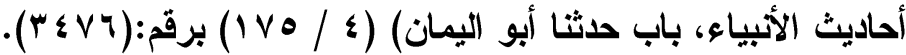

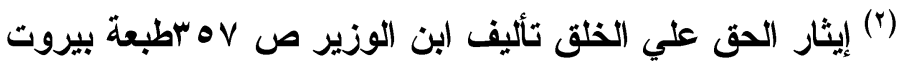


ويبدو موقف الثيخ رشيد رضا من الاختلاف المشروع أثشهر من أن

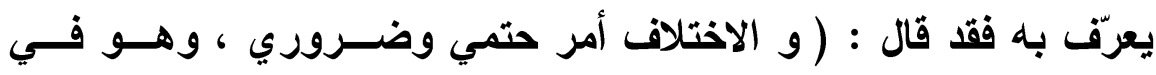

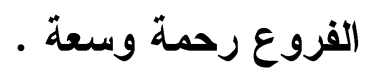

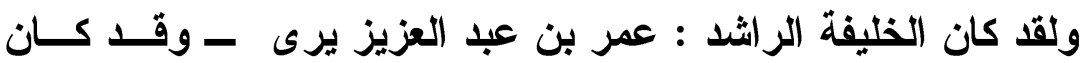

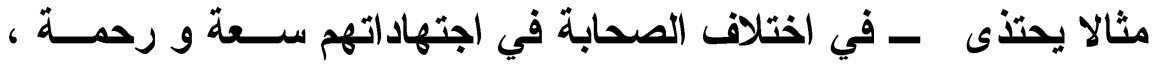

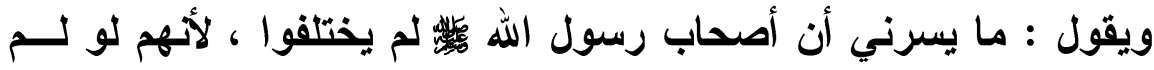

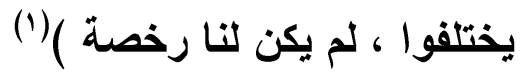

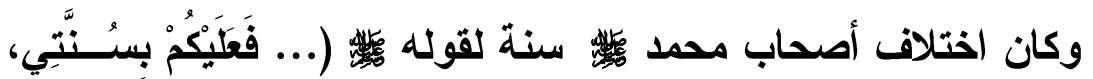

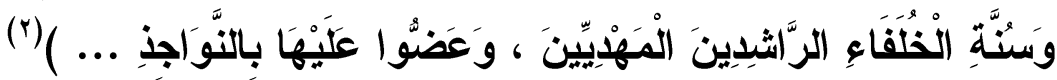
ونقبض علي خصائص فكرية بارزة لسلف الأمة : من اقتدار واضح علي التسامح عند الاختلاف في الاجتهاد فقد روي ابن عبد البر بســنده إلى يحي بن سعيد قال : (ما برح المستفتيون يستفتون فيحل هذا ويحرم

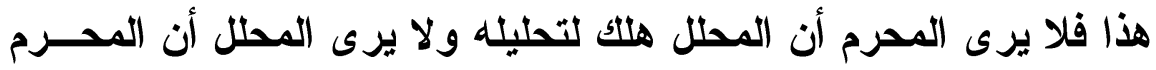

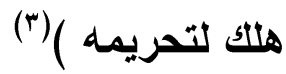

(1) إيثار الحق علي الخلق تأليف ابن الوزير ص V V سطبعة بيروت

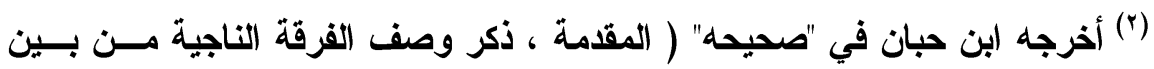

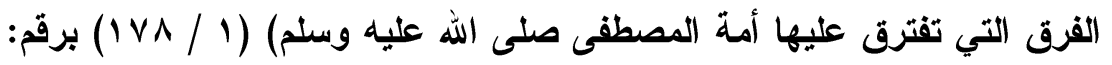

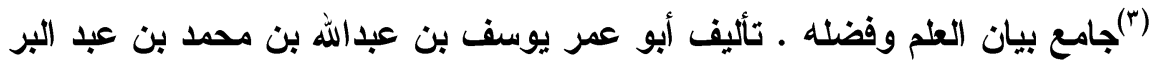

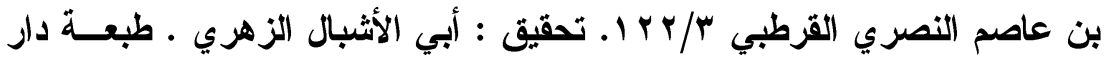

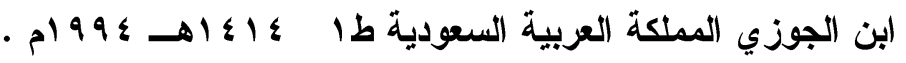


ومهما يكن من شيء فقد ظل أدب السلف الصالح في أخذهم بما أراد الله تعالى من اليسر لهذه الأمة فقد تحاشى علمـــاء الســـف التعصــب والتضييق علي المسلمين ، واتقوا ما يؤدي إلى التفرق بين المســلمين فكل عالم من علماء السلف كان يرى في صاحبه أنه تمسك بالأصــول ،

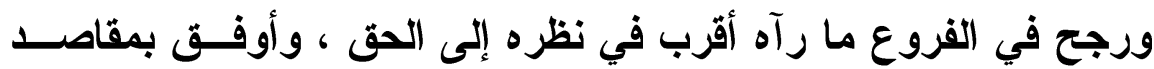
الإسدلام ، ولنكن علي وعي بحكمة أئمة السلف في سماحتهم وتواضعهم

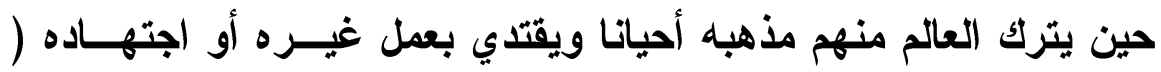
فنرى الشافعي رضي الله عنه مثلا يثرك القتوت في صلاة الصبح حسين صلي في مسجد أبي حنيفة.

وسئل أحمد رضي الله عنه عمن رأي الإمام احتجم ثم قام إلى الصلاة ولم يتوضأ أيصلي خلفه ؟ فقال : كيف لا أصلي خلف مالك وســيد بـن (المسيب ؟!! مع مخالفة ذلك لمذهبه)(") ويجب أن نعلم أنه كلما ضاق الأمر اتسع (وأن الصحابة تفرقوا فـي الأقطار فكل روى ما شاهد ... فإذا صحت الروايات بصفات متعددة كـــان ذللك دليلا علي أن الأمر واسع ، والكل سنة متبعة ، ومن تمام السنة في

(1) مقدمة " المغني " لابن قدامة ص r r تأليف : أبو محمد موفق الاين عبدالله بـن

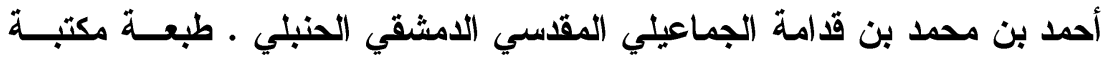
القاهرة 
مثل هذا النوع : أن يفعل المسلم هذا تارة، وذلك تارة أخرى ، وهذا في

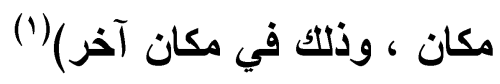

ويجب أن نعي أيضا أن الأئمة كانوا ينسبون اجتهادهم إلى أنفســهم

حتي إذا أخطأوا رجع الخطأ أليهم لا إلى الإسلام ـ ولا يغيب عن وعينـا

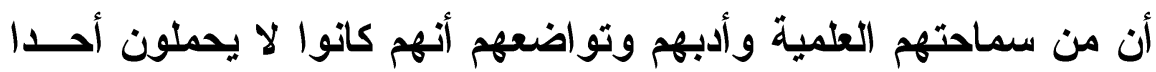

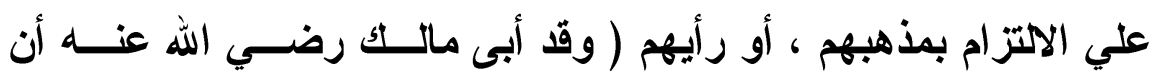

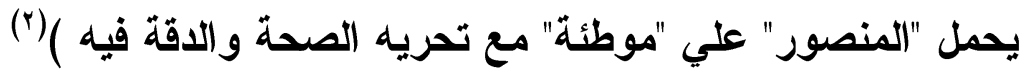
كما أن أئمة السلف كانوا ينهون الناس عـن تقليـــهم ، أو اتخــاذ مذهبهم حجة علي غيرهم أو التعصب لاجتهاداتهم ... ويؤكد الإمام أبــو حنيفة ذللك في قوله ( لا يحل لأحد أن يأخذ بقولنا ما لم يعلم مأخذه مـن

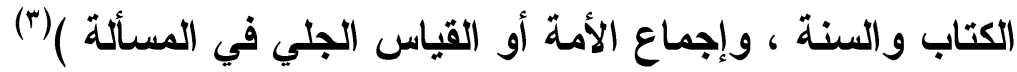
و البارز في جميع مذاهب العلماء قولهم " إذا صــح الحــديث فهــو مذهبي"

(1) مجموع الفتاوى ـ تأليف : "ابن تيمية" تقي الاين أبو العباس أحمد بن عبــالحليم

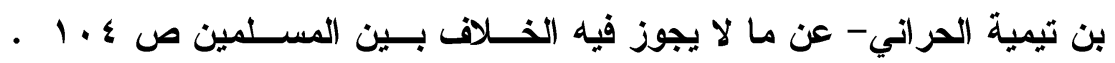

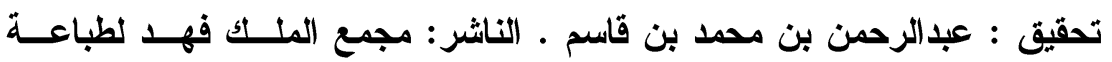

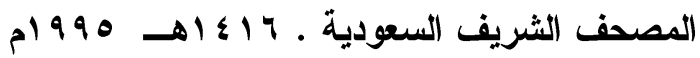

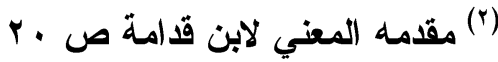

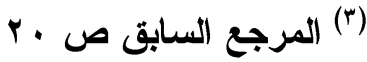


هذه أطر اف عن بعض ما كتب عن سماحة أئمــة الســـف وأدبهـــ وتواضعهم فيما اختلفوا فيه فقد كان يعذر بعضهم بعضا بل يعذر الإمــام نفسه بقوله " هذا ما قدرنا عليه فمن أتانا بما هو أفضل منه قبلناه " وما أرى أن إماما - من أئمة السلف الصالح - جرح أو سفه مذهب غيره من الأيمة فنري عالما : يضعه البعض في مصاف المجتهدين . وير اه آخرون : مجدفا مجترئا علي الله والدين . وهناك : من يرميه بالتضليل أو التفسيق أو التكفير . وهذا هو ما يباعد بينا وبين القدماء في فهم وتقويم الفكر الإسلامي. فلا كاتت حياتهم الفكرية ــ أئمة السلف الصالح ـ تشكل بالضرورة رافدا من أهم روافد الفكر الإسلامي •

أمسا الآن فقد اختلف الناس في مدي التزام كثير من علمــاء الأمسـة فرموهم قوم : بالتشكيك والفسوق و ... ودافع عنهم آخرون

وأحال قوم التزامه الديني علي جرائر النحل ، و الحمل ، والافتراء .

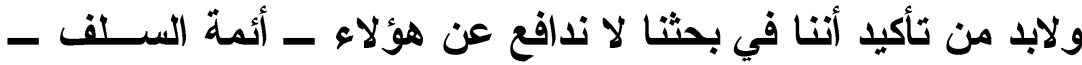

لأهم رضوان الله عليهم أجمعين أعلي مكانة وشأنا مما تضيفه الكلمــات

ولا نهاجم كل علماء عصرنا وفيهم مسن رصــــ الواقــع الفكـري فضائله.... ومدح مآثر ما ترك لنا وراعه من علم ونبل وشجاعة فكريـــة وإخلاص للاين و ... ولكنتا نتتقل إلى تحديا ما يجب توحيا الفهم لــه . وما يجوز تعدد الفهم فيه : 
فها يجب توحيد الفهم له ، ولا يجوز الاختلاف فيه هو :

$$
\text { (أولا : ما هو معلوم من الدين بالضرورة . }
$$

ثثانيا : ما هو قطعي النص (أي الثبوت) ... قطعي الدلادة .

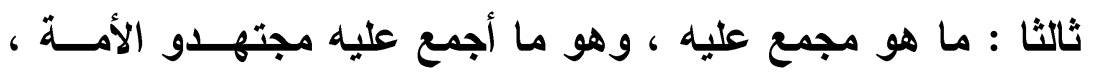

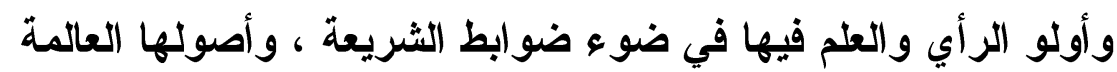
وما عدا ذلكك يجوز اختلاف الأفهام فيه .

ولكن بعض الناس مما ضاق أفق الفهم لايهم ، قد أرادوا أن يوحدوا

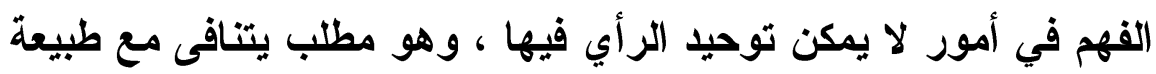

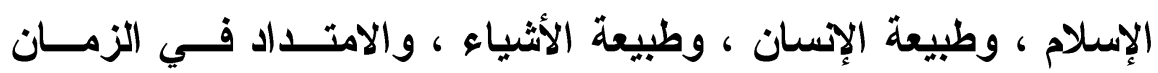
و (المكان)( الإنلم ، وطن)

وإذا كان الاختلاف في الأحكام ضرورة. وسعة، ورحمة، فمـاذا إذن عن الاختلاف الواقع في بعض الأصول عند الفرق الإسلامية ؟ يجيب جمال الدين القاسمي بقوله :( ولا يصح ذم أهل الفرق علــي

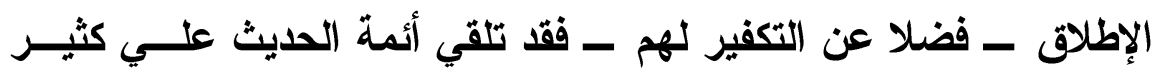

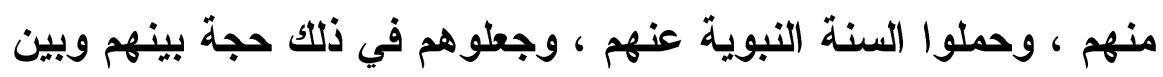
ربهم •

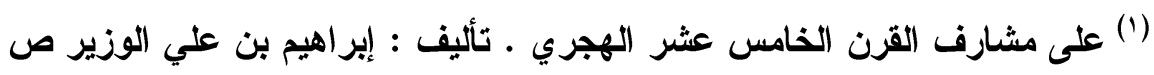

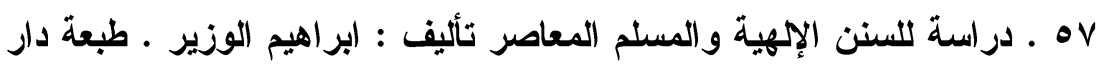

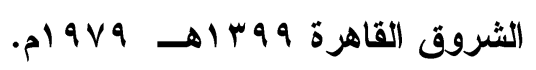


وقد روى البخاري ومسلم وغيرهما عن عدد كبير مـن المعتزلـة ،

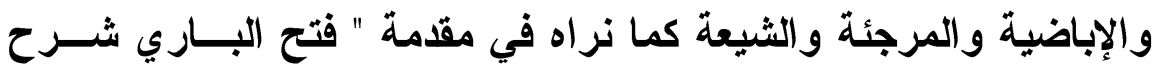
صحيح البخاري " و "ثرح التثريب" للسيوطي وميزان الاعتدال " للأهبي

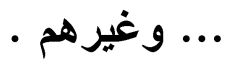

وقد ذهب كل من هؤلاء إلى مـــــا رآه الأوفـق بكــلام الله تعـالى ، والأليق بكماله وجلاله، وهم يستندون إلى القرآن الكريم والسنة المطهرة

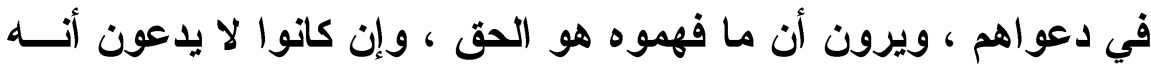

مراد لله تعالى ) (1)

ومن المعروف أن الخلاف بين الفرق الإسلامية العقديــة كالجبريــة

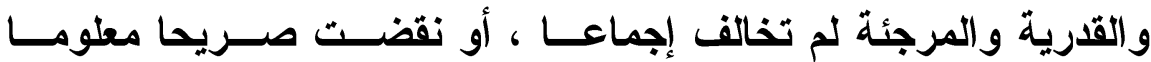
بالضرورة من الاين

يقول القاسمي وهم ( مجتهـون لعــوم مفهــوم الاجتهــاد : لغــة

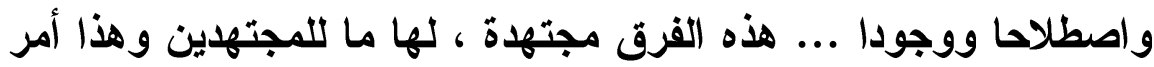

(r)( لا يرتاب فيه منصف

وخلاصة القول في قضية الاختلاف المشــروع ... و التفــرق غيـر المشروع: أن العلماء أفلدوا في توجيه الأمة إلى ما يجب توحيد الفهم له له

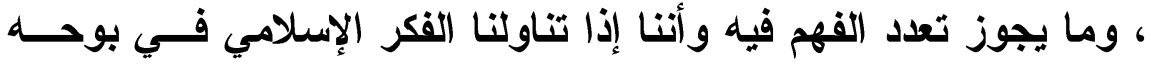

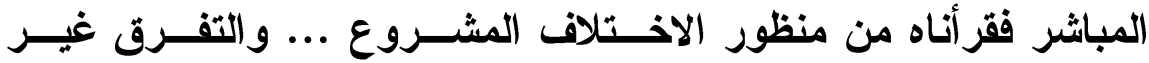

(1) تاريخ الجهمية والمعتزلة. تأليف: الثيخ عبدالجيليل عيسى - ما لا يجـهوز فيسهـ

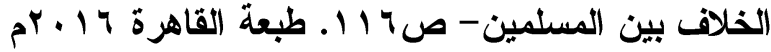

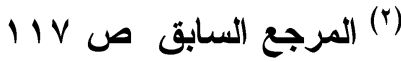


المشروع... فسيصدمنا تعصب كل شيعة لمذهب في الأصول أو الفروع ، وهو من أكبر الكبائر الثابتة بالكتاب والسنة . وما وعاه الباحث أن " التلفيق في الفروع "(1) يجوز فــي المــذاهب الفقهية ـ (ولا شيء مما تعصب له المتعصبون بقطعي ولا بمجمع عليه . فمن مقضي أصول الجميع : ترك أسباب التفرق والاختلاف وأن مـــا

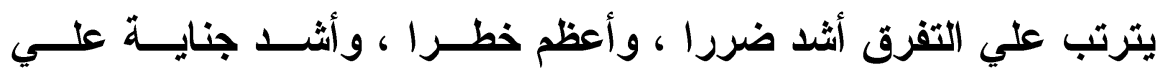
الإسلام والمسلمين مما هو مختلف عليه في غالب الأمر . وأنه لمن الجهل الفاضح ، والجناية علي الــدين : أن تهـدم هـــه الأصول القطعية ــ في النهى عن التفرق والاخــتلاف ـ بأقيســة مــن - الظنون

وقد ثبت أن التبي كله كان يجيب على كل مستفت بما يناسب حاله . وأن بعض فتاواه صلوات الله وسلامهه عليه كانت رخصــا عامــة أو خاصة ) (r) (r) بعان كيف إذن أباح العامة لأففهه حمقا وجهلا اعتقاد العصمة لفــرد أو جماعة ونسي هؤلاء أن العصمة لا تكون إلا للأنبياء صلوات الله وسلامه

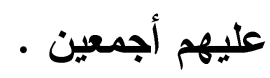

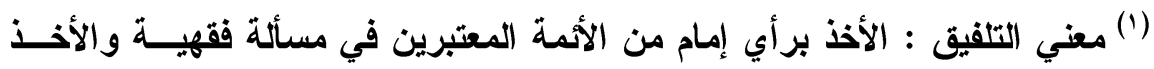

$$
\begin{aligned}
& \text { برأي غيره في مسألة أخري متي رجحت الأدلة }
\end{aligned}
$$

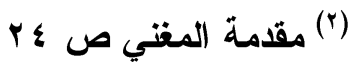


فتنة تكفير المصلمين بيين التطرفه والإعتكال

إن اعتقاد العامة أو ظنهم في فرد أو جماعة العصمة بحيث تجعلون

رأيه ، أو حكمه، أو منهجه الحق وما عداه باطلا يعني العجز عن تبريز

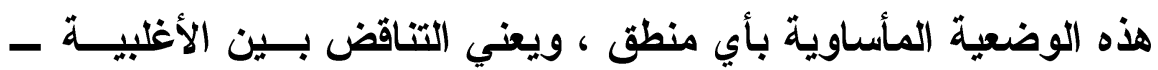
العامة - وبين الفكر الإسلامي الواضح ، ويعني حتمية الخجل من هــــا العالم الأي عصمه الآخرون ويدوسهم لغلاظة جهالهم . 


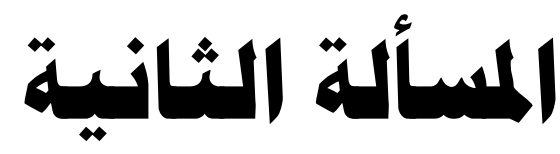

الإسعلإم. والإيمان . والكفر.

وتثتمل هذه المسألة علي ما يأتي :

ا- تعريف الإسلام والإيمان والكفر .

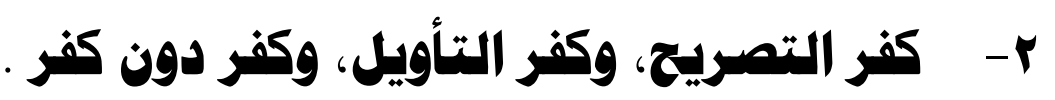

r- تكفير هن لم يكفر الكافر . 


\section{فتنة تكفير المسلمين بيين التطرف والاعتكال}

تعريف الإسلام ، والإيمان ، والكفر

$$
\text { الأولا: تعريف الإسلام : الإسلام في اللغة : ( الإذعان والقبول . }
$$

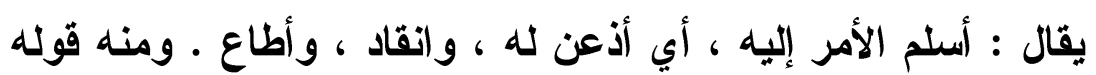

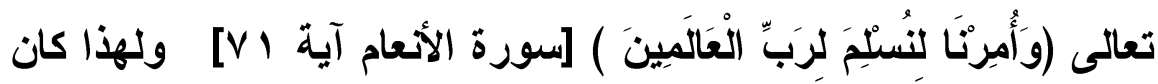

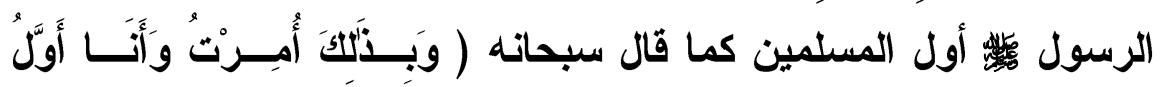

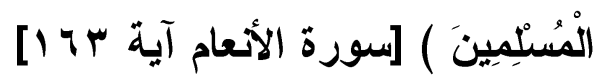

ويتبدى بوضوح أن الإسلام في الثريعة معناه : ( إظهار الخضوع

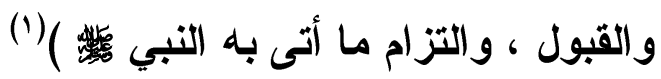

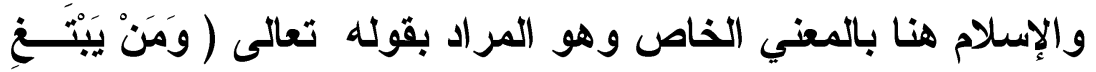

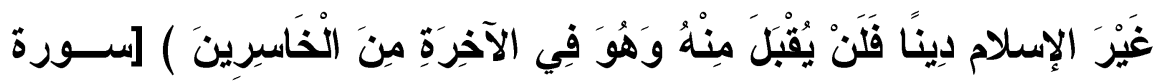

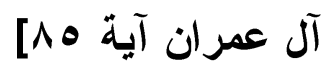

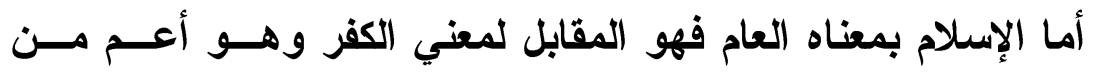

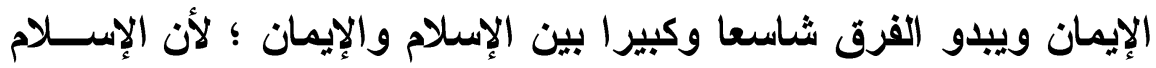

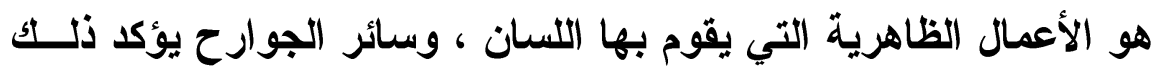

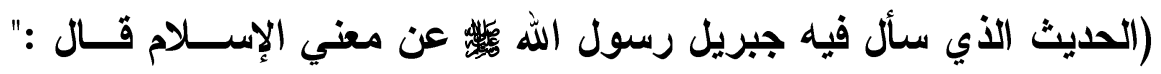

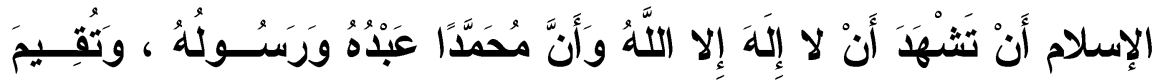

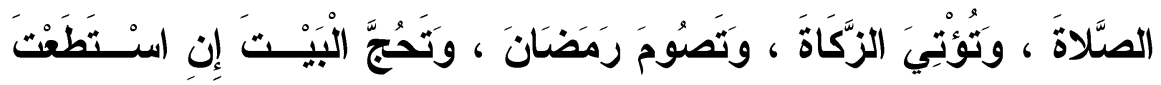

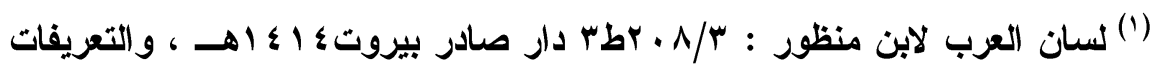

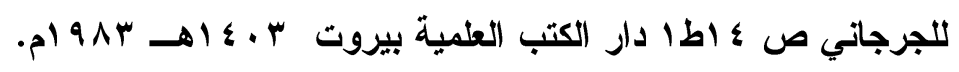




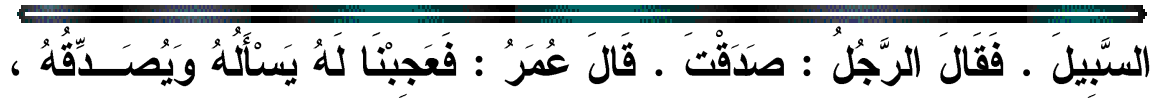

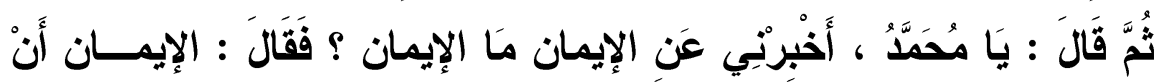

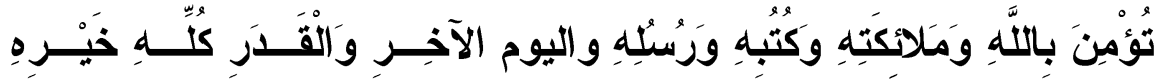

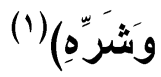

ويقال هنا : إن الإيمان هو التصديق الباطني بــالأمور أو القضــايا

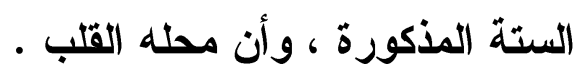

فالعمل ليس جزعا من الإيمان بل هو ثمرته و النصوص الثــرعية هي التي أملت علي العلماء تعريف الإيمان فقالوا ( الإيمان في اللغــة :

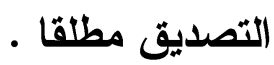

قال تعالى حكاية عن إخــوة يوســف عليـــهـ الســلام ( وَهَهَا أَنـتَ

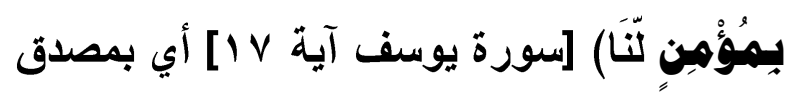

وشرعا : هو تصديقه

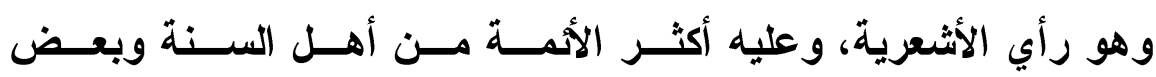

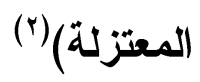

ولقد أذهلتنا هذه الوضعية المقتدرة عن معني التصديق الأي يصـل

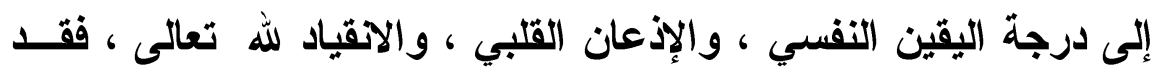

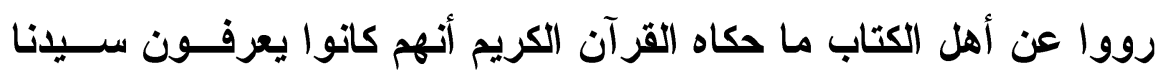
محمداً

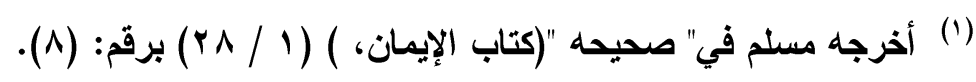

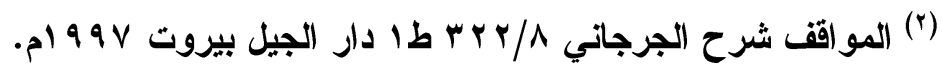




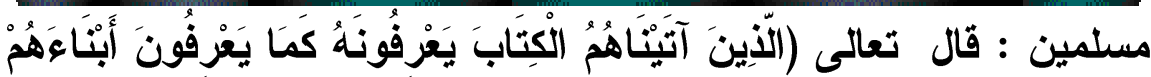

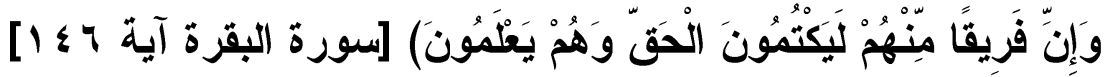

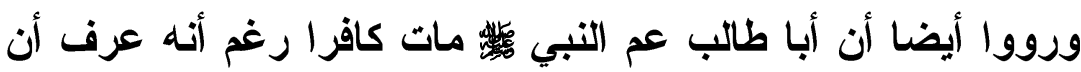
الإسلام حق ، وقد أخبرنا أبو طالب عن نفسه فقال : ولقد علمت بأن دين

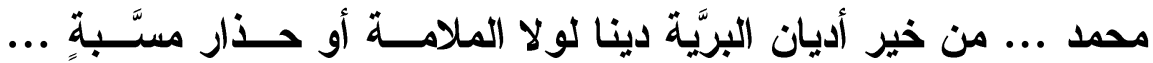
لوجتتني سمحا بذالك مُنيا وروى إبليس اللعين عن نفسه أنه كان يعرف ربَّه و هذه المعرفة لم تجعله مؤمنا

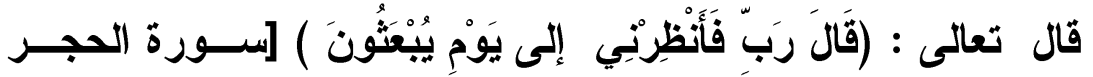

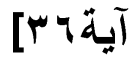

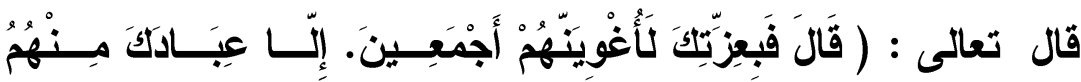

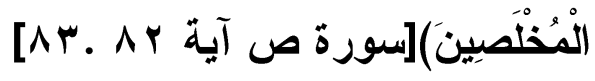

ويبدو أن التصديق لابد أن يصل إلى درجة الإذعــان ، والانقيــاد ، و التسليم • ومحل التصديق هو قلب المؤمن .

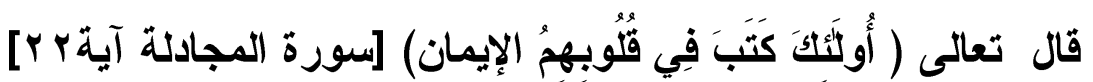

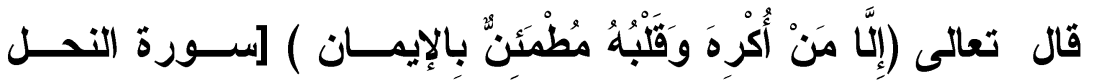

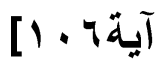

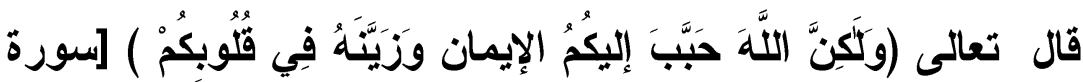

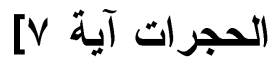

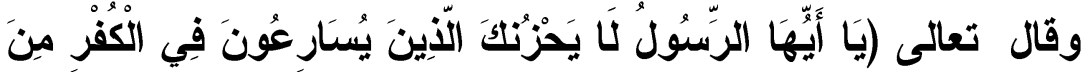

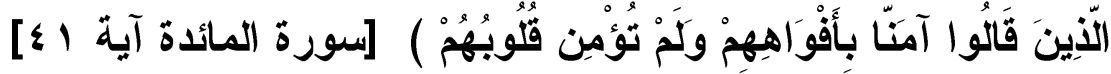


وأما الأحاديث النبوية الثريفة الدالة علي أن الإيمان محلــه القلـ

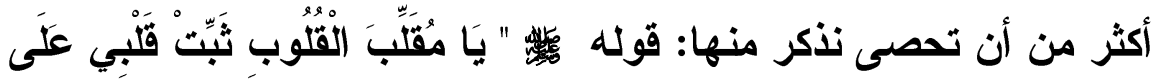

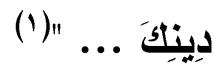

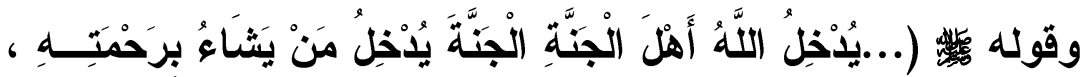

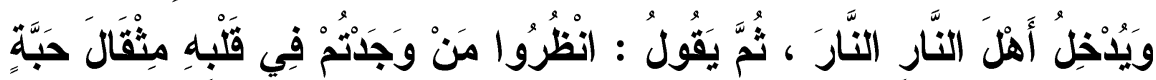

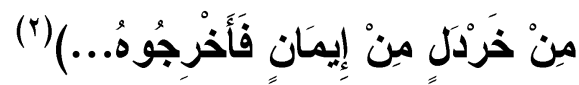

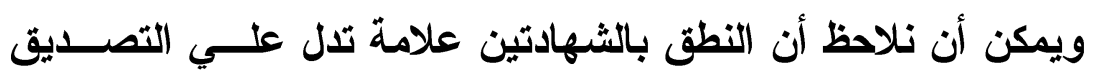
القلبي ، وهو شرط لإجراء الأحكام الانيوية -على المســلم- كـالزواج والميراث ، وحل ذبيحته ، و الصلاة خلفه وعليه ، و الافن فـي مقــابر المسلمين ، فلما كان الإيمان خفيا في القلب ، كان النطــق بالشــهادتين علامة تلل عليه ، فمن صدَّق بقلبة ونطق بالثهادتين ، فهو مؤمن عند الله فياخله جنته ، ومؤمن عندنا فنعامله معاملة المسلمين . ومن صدق بقلبه ، ولم ينطق بالشهادتين ، فهو مؤمن عند الله فقط،

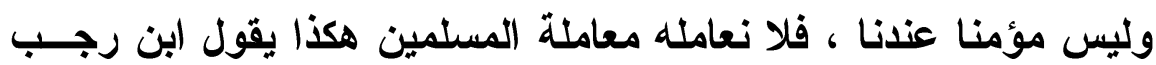

(1) أخرجه الترمذي في" جامعه "(أبواب القدر عن رسول الله صلى الله عليه وســلم.،

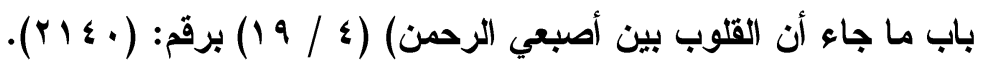

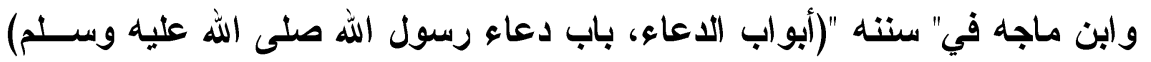

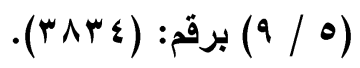

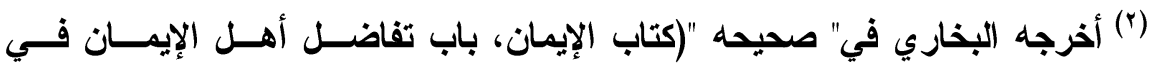

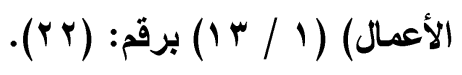

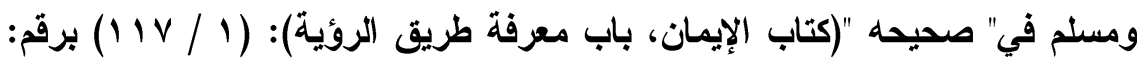
( $(1 \wedge r)$ 
الحنبلي : " ومن المعلوم بالضرورة أن التبي كإن كان يقبل كل من جـاءه يريد الاخول في الإسلام بالنطق بالشهادتين فقط ، ويعصم دمه بــلتك ،

ويجعله مسلما )(' (1)

والو اقع أننا لا نعاني طويلا لنفهم أن :

1-الإيمان شيء والعمل بالشرع شيء آخر ، لأن العمل لـــو كــان

جزعا من الإيمان لكان من قصر في العمل ، زال عنه الإيمــان ، ومــع

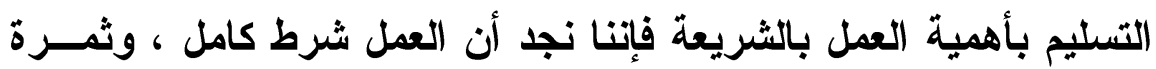
من ثمرات الإيمان ، فمن قصر في العمل يكون ناقص الإيمان ولا يــزول

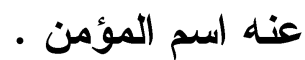

والنصوص الثرعية تؤكد أن الأوامر والنواهي تــأتي بعـــ إثبــات

الإيمان ، وهذا يدل علي أن الإيمان شيء والأوامر والنواهي شيء آخر.

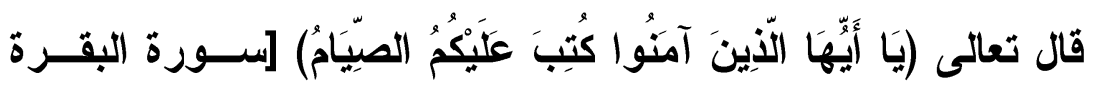

[آية

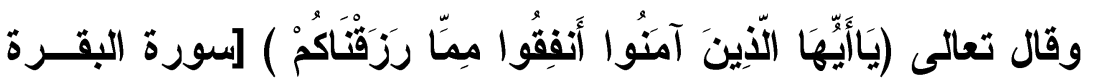

[آية

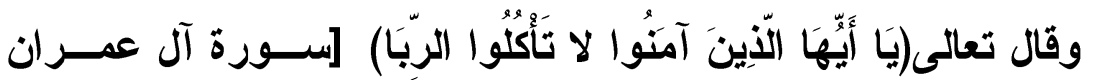

آية.

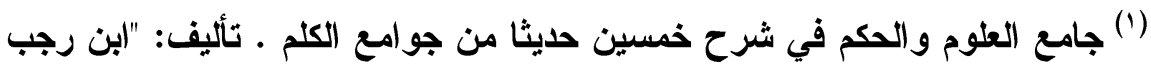

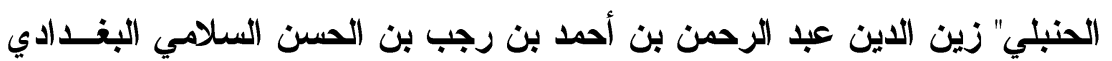

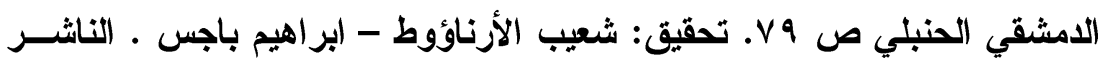

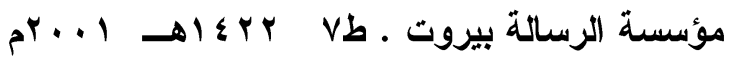




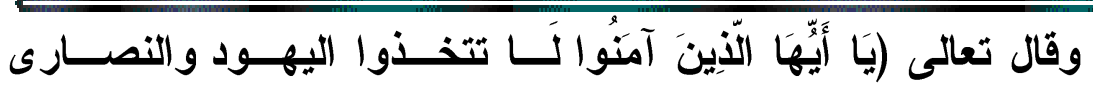

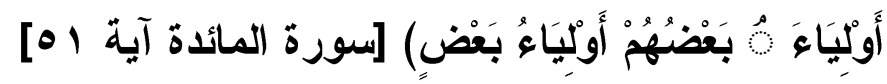

هذه النصوص الثرعية وغيرها دالة علي أن الإيمـان ، والأعمــال

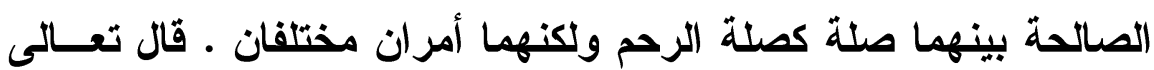

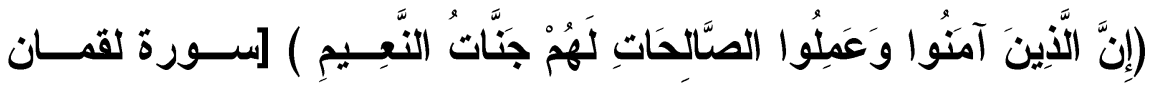

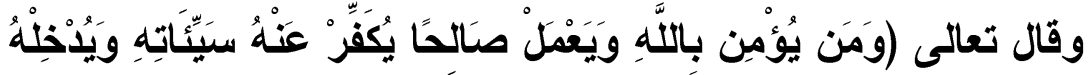

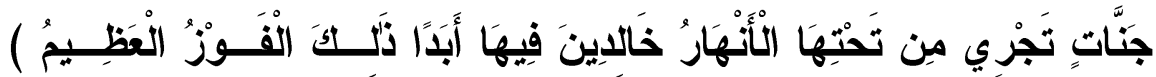
[سورة التغابن آية 9

ويبدو عطف الأعمال على الإيمان يفيد المغايرة

وحين نتتقل إلى الأحاديث النبوية نجد الحديث الأي رواه أبو هريرة

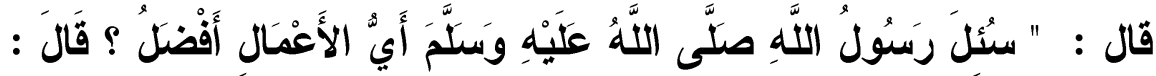

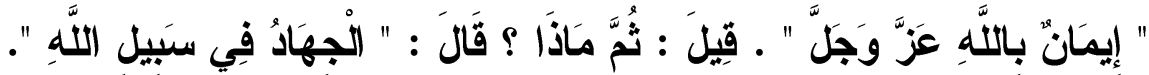

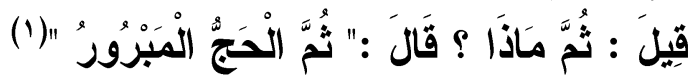

r- ويخطئ من قد يظـن أن الإيمـــان والمعاصــي لا يجتمعـــان ، فالنصوص الثرعية دالة على أن الإيمان والمعاصي قالي يجتمعان .

(1) أخرجه البخاري في" صحيحه "(كتاب الإيمان، باب من قال إن الإيمان هو العــل (إ)

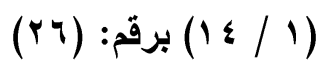

ومسلم في" صحيحه "(كتاب الإيمان، باب بيان كون الإيمان بالله تَعَالَى أفضل الْأعمال)

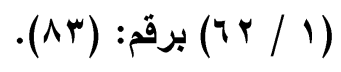




\section{فتنة تكفير المسلمين بين التطرفه والاعتكال}

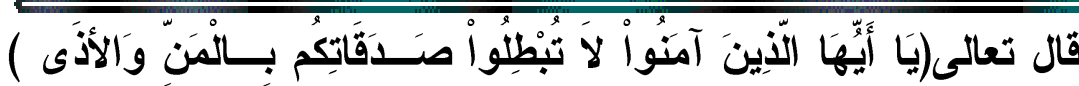

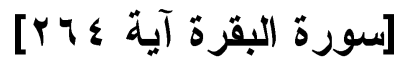

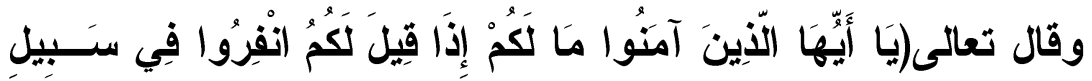

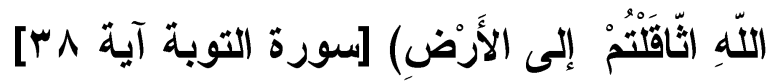

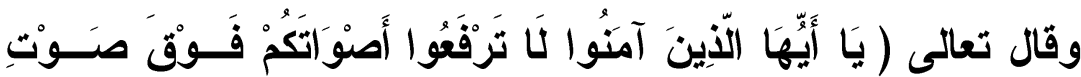

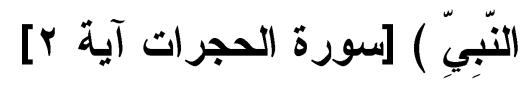

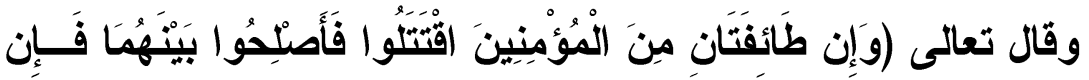

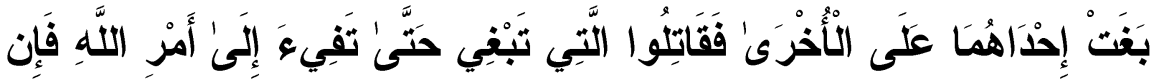

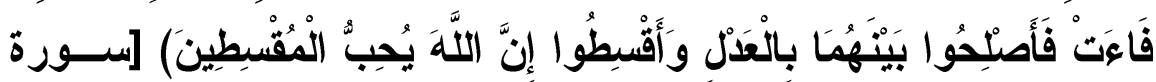

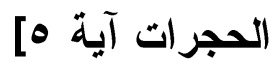

وعلينا أن ندلق في الحديث الذي رواه أبو ذر رضي الله عنه قال :

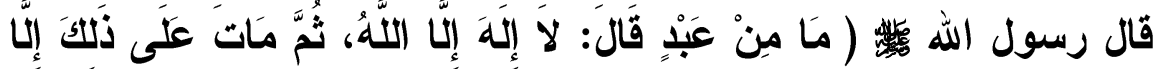

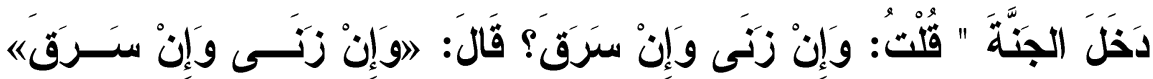

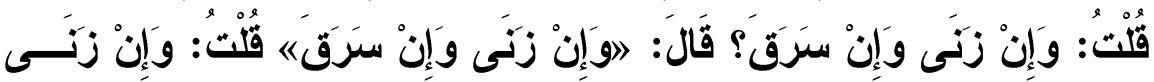

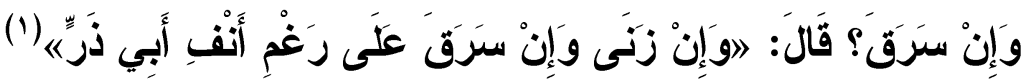

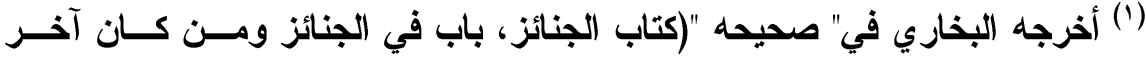

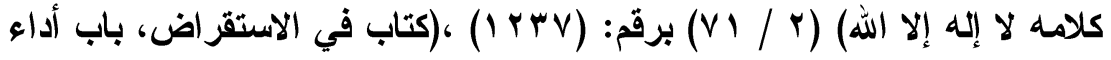

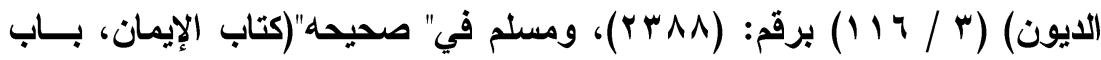

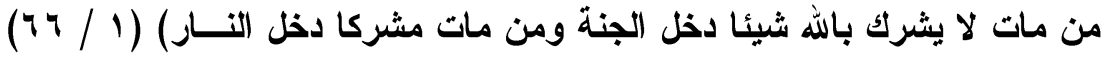

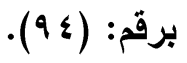


ويتبدى بوضوح أن الله تعالى جعل الإيمان شــرطا لقبــول العـــل

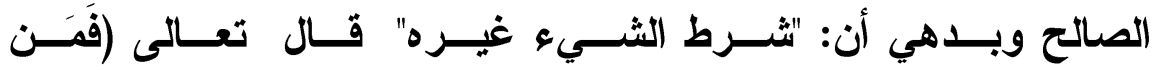

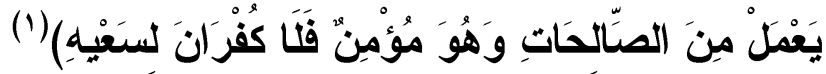
وقد عرف أهمية الإيمان الربيع بن أنس حين قال : " ... شبه شجرة

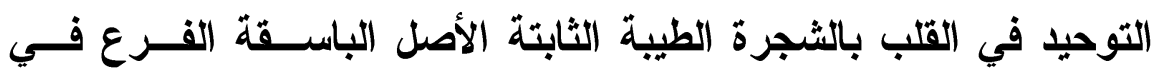

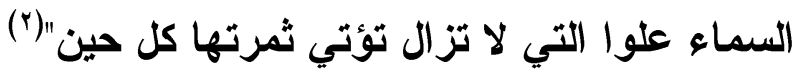

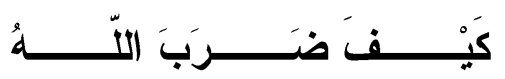

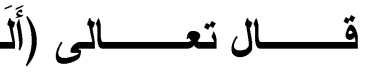

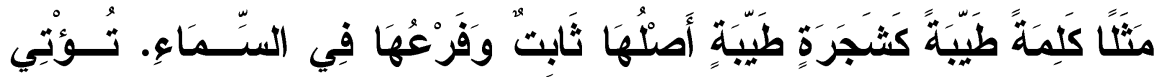

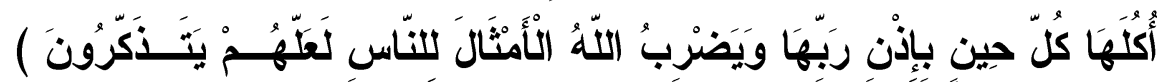

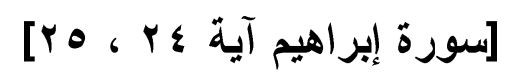

عـ من الحق أن يقال : إن قضية التوحيد تثكل في الفكر الإسلامي

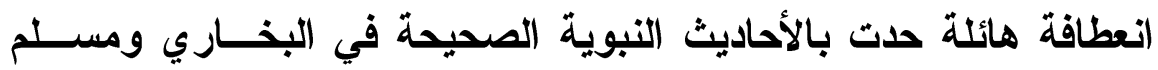
وغيرهما أن تصرح أن الله تعالى يُخرج أقواما من الموحدين من النـار برحته جل وعلا يسمون عتقاء الله ، أو عتقاء الرحمن لم يعملوا خيرا قط ـ هكذا تقول الأحاديث عن شفاعته "جل وعلا"

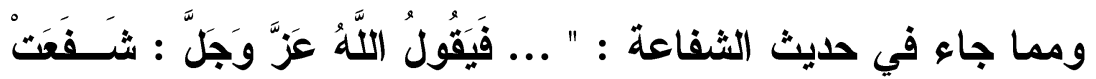

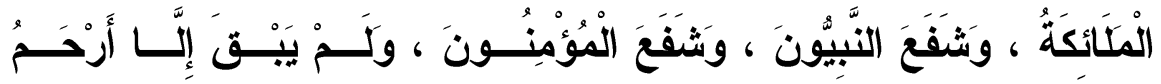

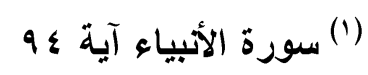

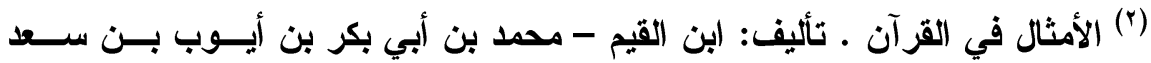

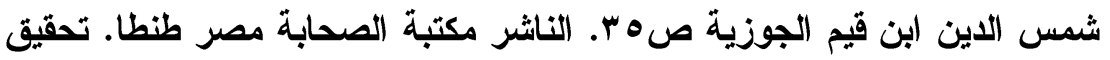

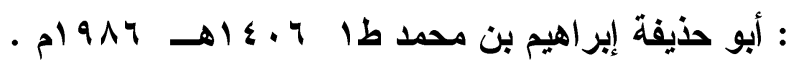




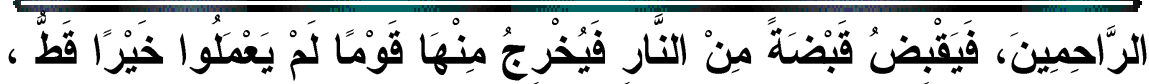

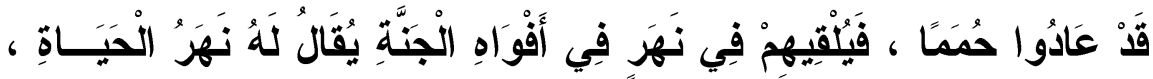

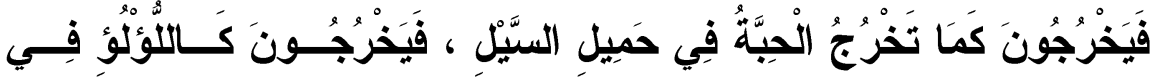

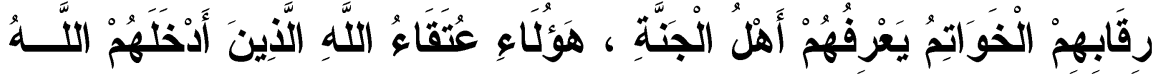

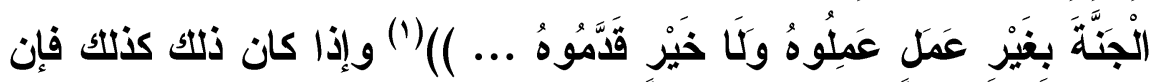

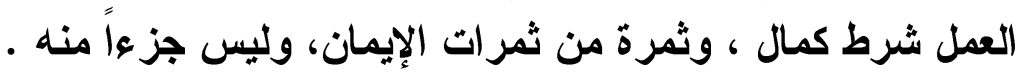
• ـ لنكن علي وعي بحكمة الأحاديث النبوية التي تصــرح بعــدم دخول مرتكب المعاصي الجنة ، ولنحاول أن نفه أن هذه الأحاديث مـن باب الترهيب والمبالغة في التنفير والزجر للبعد عن هذه الذنوب ـ وليس المراد منها نفي الإيمان أو عدم دخول الجنة، ومن هذه الأحاديث النبوية:

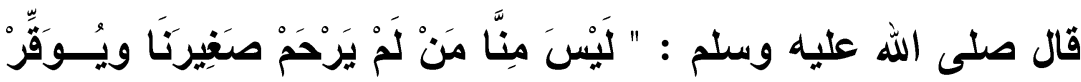
(ץ)" كَبَيرنَا

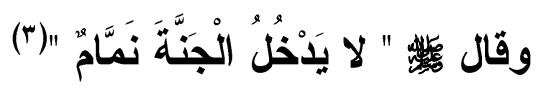

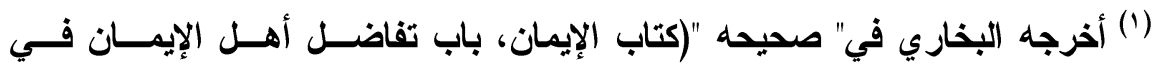

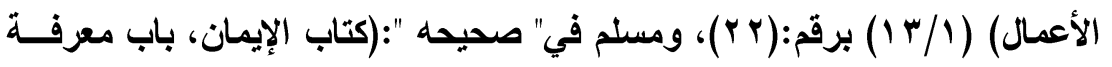

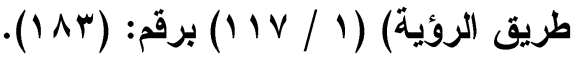

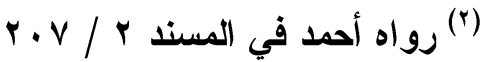

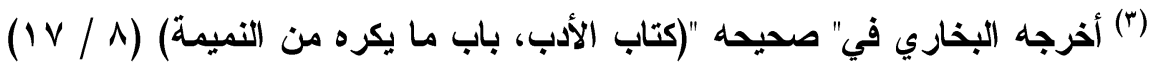

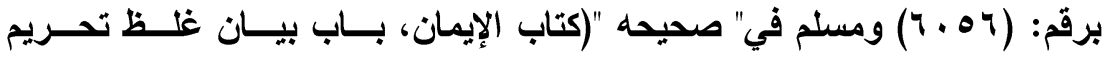

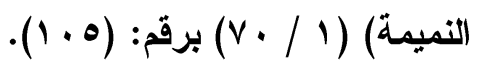




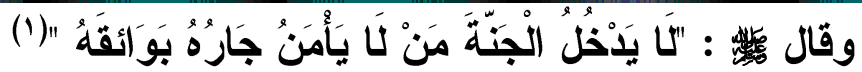

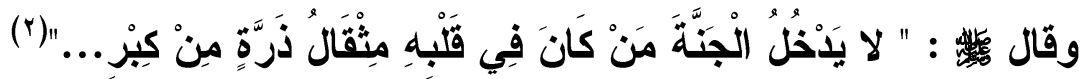

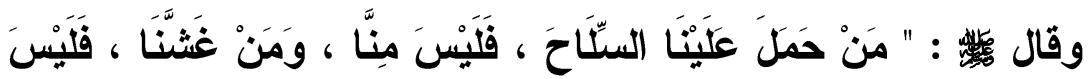

منَّاَّ "(r)

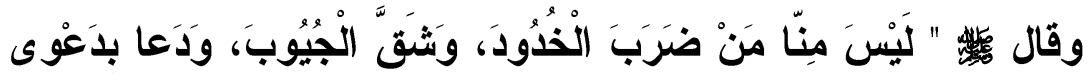

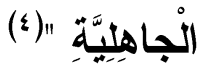

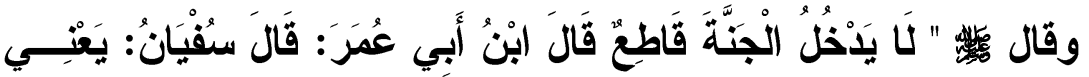

قَاطِعَعَ رَحِمٍ. "(•)

(1) أخرجه البخاري في" صحيحه "(كتاب الأدب، باب إثم من لا يأمن جـــاره بوايقــهـ

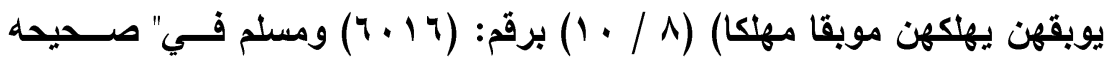

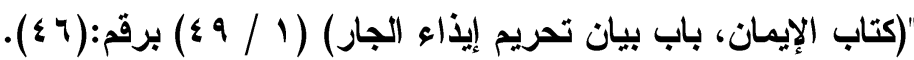

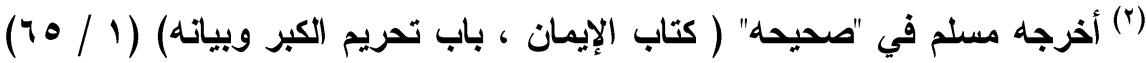

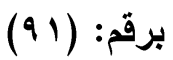

(") أخرجه مسلم في" صحيحه " (كتاب الإيمان، باب قول النبب صلى الله عليه تَعَـالَى

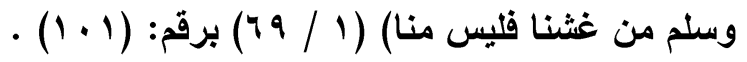

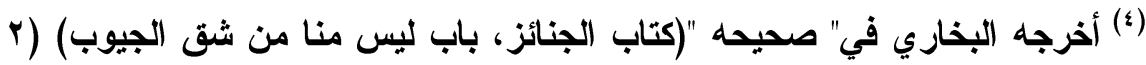

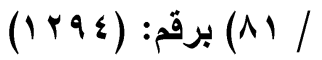

(•) أخرجه البخاري في" صحيحه " (كتاب الأدب، باب إثم القــاطع) (1 / ه) بــرقم:

$(\circ 9 \wedge \varepsilon)$

ومسلم في" صحيحه "كتاب البر والصلة والآداب، باب صلة الرحم وتحريم قطيعتها)

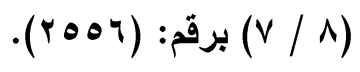




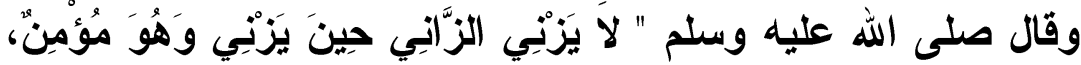

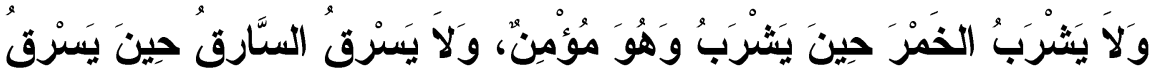

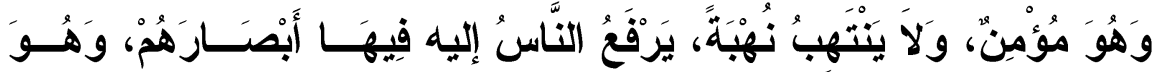

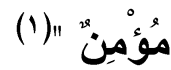

ويبدو أن المؤمن لا يفعل هذه المعاصي وهو كامل الإيمسان فهـــه الأحاديث تنفي كمال الإيمان ، ولا تنفي أصله وصحته .

7

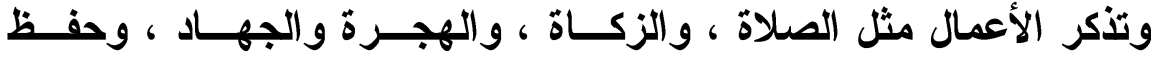
الأمانات ... الخخ على أنها تتكلم عن المؤمن الكامل أو الإيمان الكامل ميع التسليم بأن هذه الأعمال علامات دالة علي وجود التصديق القلبي الــــي

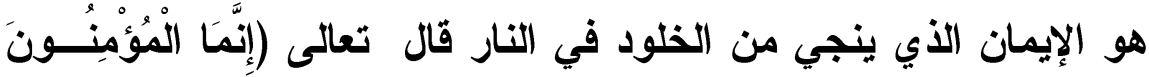

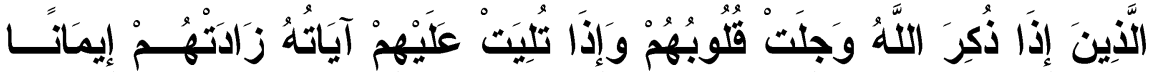

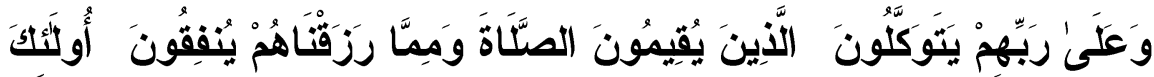

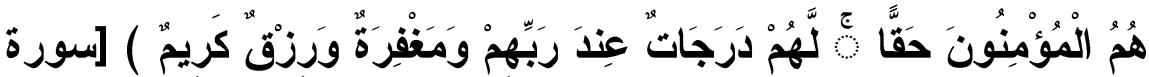

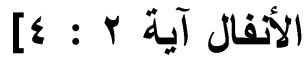

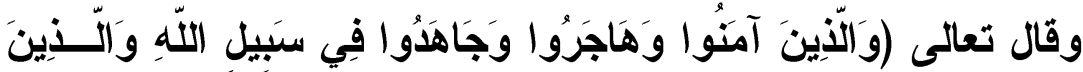

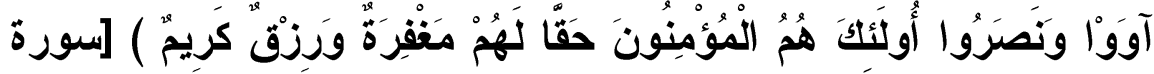

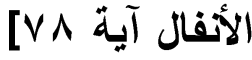

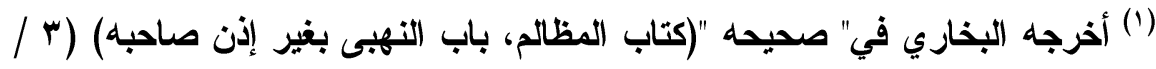

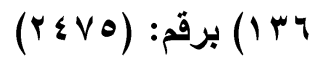




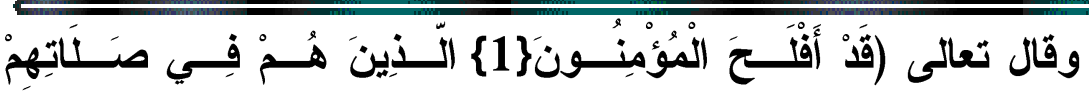

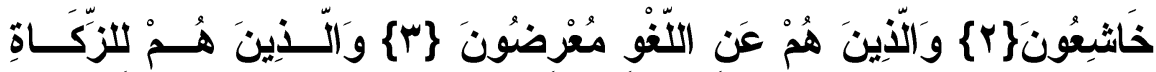

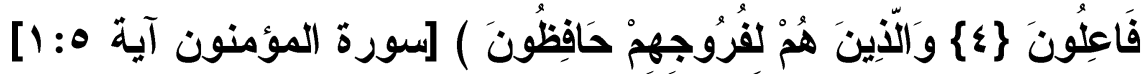
ويتبدى بوضوح أن قول الســلف وعلمــاء العـــيث أن الإيمــان :

"تصديق بالجنان ، وإقرار باللسان ، وعمل بالأركان "(()

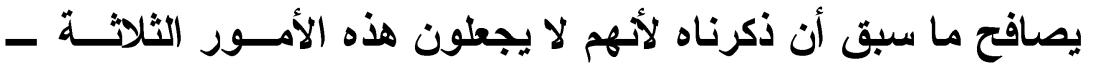

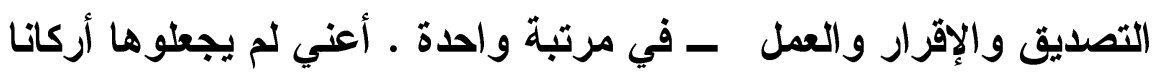

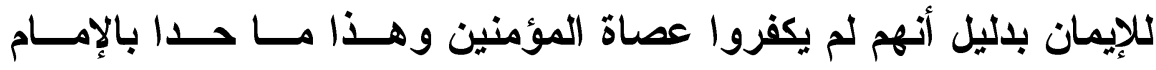

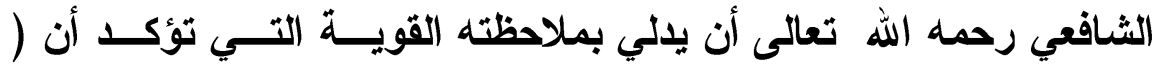
الإيمان هو : التصديق ، والإقرار ، والعمل : فالمخل بـالأول وحسده : لهـل منافق • وبالثاني وحده: كافر • وبالثالث وحده : فاسـق و ينجسـو مــن

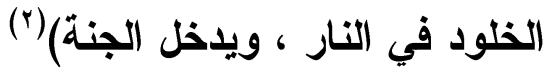

ويمكن النظر إلى مفهوم الإسلام والإيمان مــن وجهـة منطقيــة لا تتجاور بالطبع النصوص الثرعية ولكنها تنطلق منها جميعا لتؤكد أن:

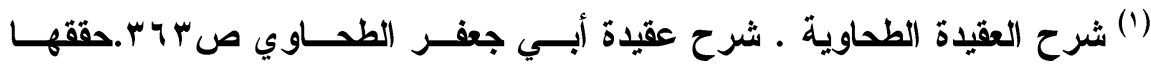

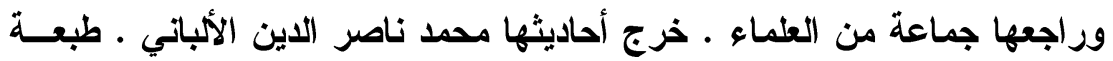

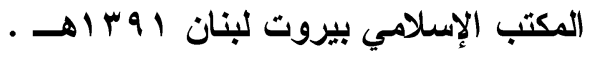

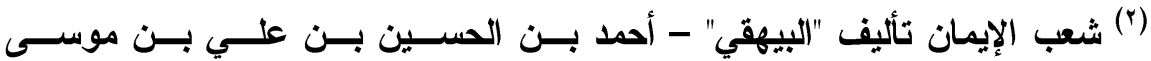

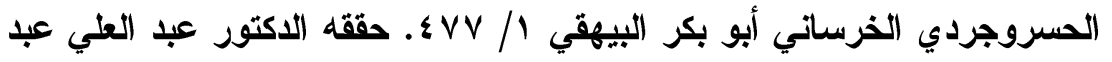

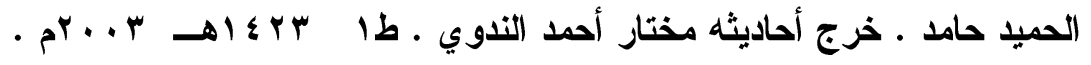


" الإسلام والإيمان إذا اجتمعا افترقا، وإذا (فترقا اجتمعا "(1) أعنـي

إذا اجتمع اللفظان في نص واحد " افترق معناهما " . وإذا ورد أحــدها دون الآخر ، شمل معنى الإسلام و الإيمان ونختصر اجتماع اللفظين في

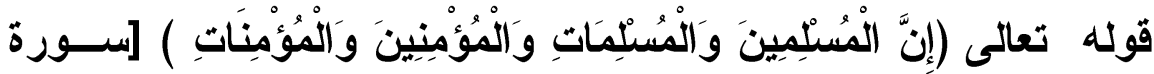

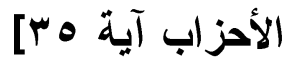

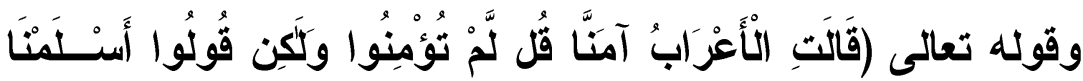

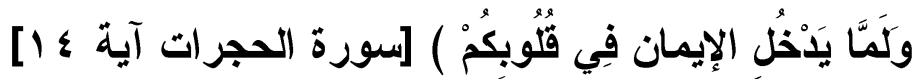
وما تؤكده هذه الآيات وغيرها أن للإسلام معنى ، وللإيمــان معنــى

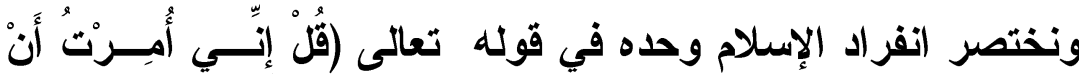

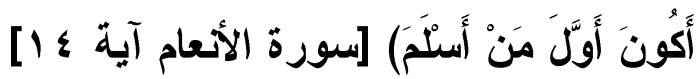

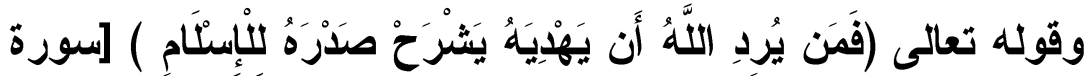

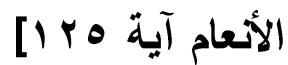
فالإسلام في هذه النصوص وغيرها يشمل الإيمان ونختصر انفر اد الإيمان وحده في قوله تعالَى (رَبَّنَا إنَّنَا سَمِعْنَا مُنَادِيًا

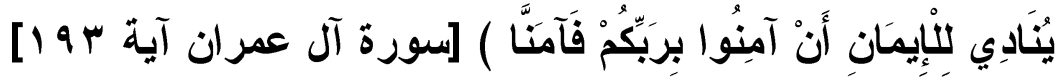

(1) (فترق معناهما ـ فكان الإسلام الأعمال الظاهرة - الثهادة ، و الصلاة ، و الزكـــاة وصوم رمضان ، والحج -. و الإيمان التصديق الباطني بالقضايا الستة - الإيمان بالله تعالى ، وملأكته ، وكتبه ، ورسله ، و اليوم الآخر ، و القضاء والقدر - . 
مجلة كلية الكراسنات الإسلإمية والعريبة بنات بنهي لسويفه العذى العاشر

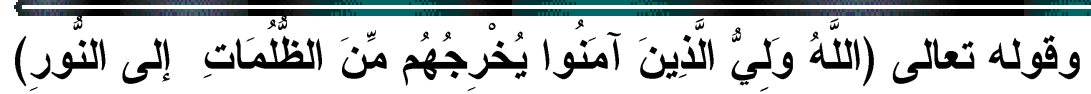

$$
\text { [r॰V سورة البقرة آية }
$$

فالإيمان في هذه النصوص وغيرها يشمل الإسلام .

هذه أطراف عن أهم ما كتب عن مفهوم الإسلام والإيمان ...

وسنتبري في بيان مفهوم: الكفر ، قبل الولوج في قضـية التكفيـر

وهذا هو موضوع المسأنة الآتية .

تعريف الكفر في اللاغة والاصطلاح :-

تعريف الكفر في اللغة :

$$
\text { نستطيع ان نقول : }
$$

إن الكفر في اللغة : معناه الستر والتغطية

قال ابن فارس : " الكاف والفاء والراء ، أصل صحيح يــل علــى

معنى واحد ، وهو الستر والتغطية "(1)

وقال ابن الاثير " أصل الكفر تغطية الشيع تغطية تستهلكه "(r)

والكفر في اللغة يطلق على عدة تسميات ، كلها ترجع إلـى معنـى

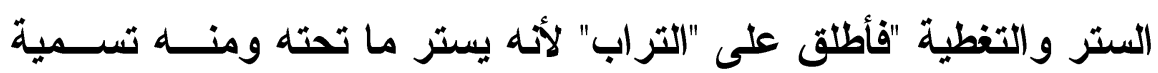

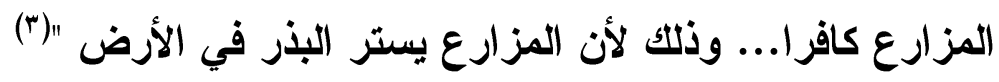

$$
\begin{aligned}
& \text { (1) معجم مقايس اللغة لابن فارس } 191 / 0
\end{aligned}
$$

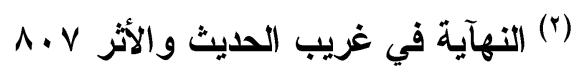

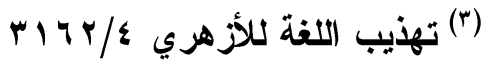


كما أطلق "الكافر" في اللغة على الليل ؛ لأنه يستر بظلمته كل شـيء وعلى البحر : لستره ما فيه . وعلى السحاب المظلم ، لأنه يستر الثمس . وعلى الارع ، لأنه يستر البلن (1) ومنه تسمية الكفارات بهذا الاسم ، لأنها تكفر الأنوب ، أب تسترها

مثل كفارة الإيمان، وكفارة الظهار (ץ) تعريف الكفر في الاصطلاح:-

يمكن أن نلاحظ ارتباط المعنى الشرعي أو الاصطلاحي للكفر بالمعنى

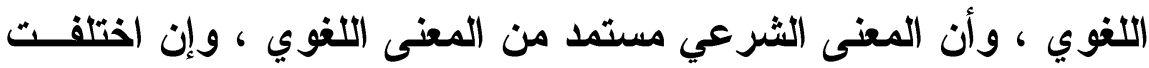
أقوال العلماء لكنها تتفق على أن معنى الستر و التغطية كامن في المعنى

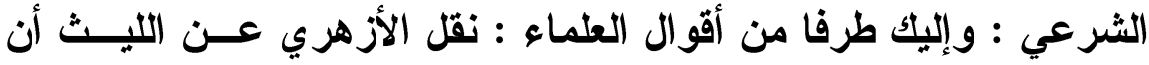

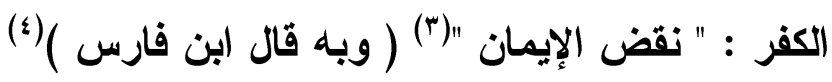
وقال ابن حزم في تعريف الكفر : " جحد الربوبية وجد نبوة نبـي من الأبياء صحت نبوته في القرآن ، أو جد شيء مما اتى به رســول

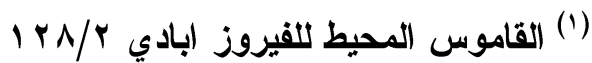

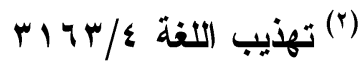

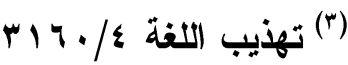

$$
\begin{aligned}
& \text { (q) معجم مقاييس اللغة لإبن فارس } 191 / 0
\end{aligned}
$$


الله

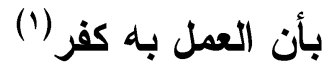

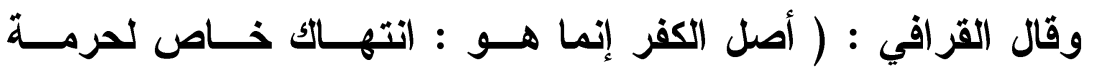
الربوبية، إما بالجهل بوجود الصانع أو صفاته العــلا ، ويكــون الكفــر

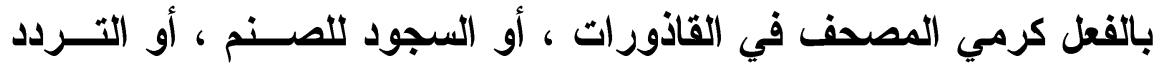

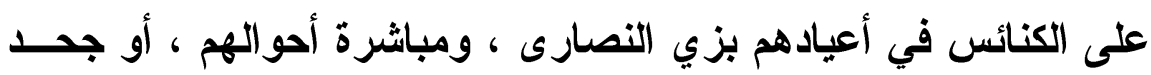

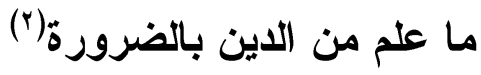

وقال ابن القيم : " الكفر جد ما علم أن الرســول

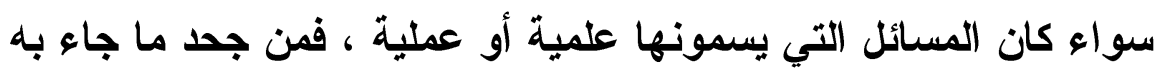

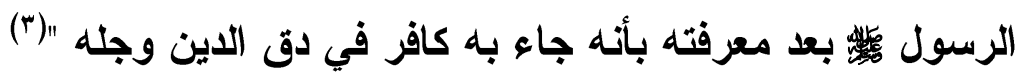
وفي كلمات قلاثل محددة المغنى واضحة الدلالة يقول السعدي : " حد

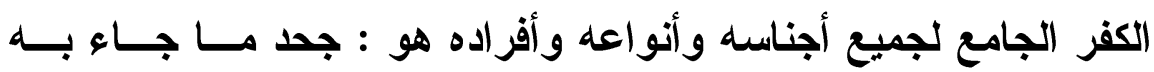

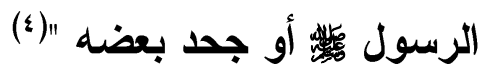
ونلاحظ أن التعريفات السابقة قد عرفت الكفر ، وحددت مفهومه بما

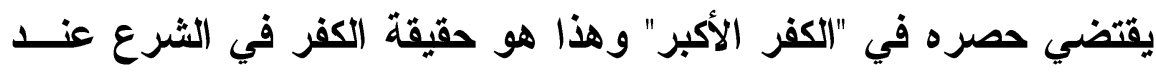

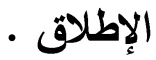

وذكر أهل التفسير أن الكفر في القرآن الكريم على خمسة أوجه :

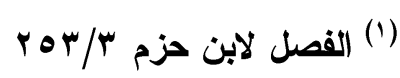

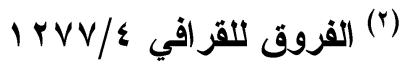

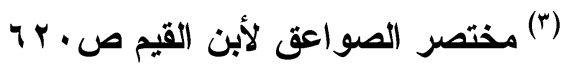

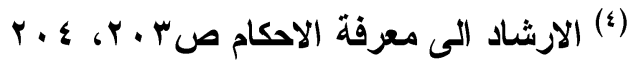




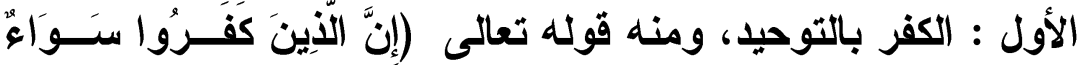

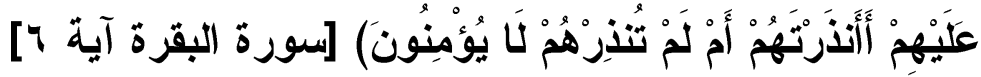

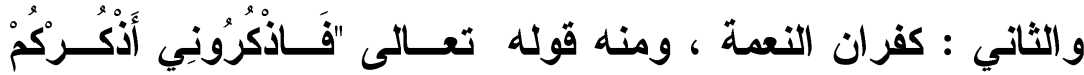

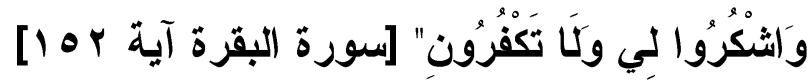

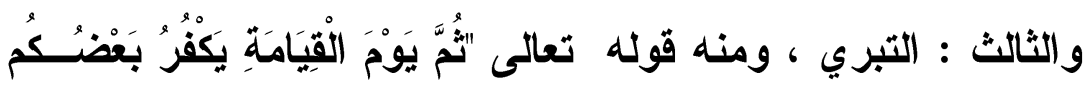

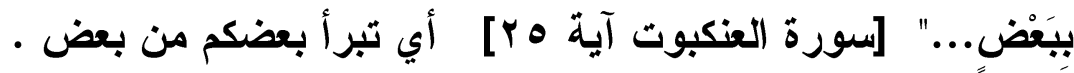

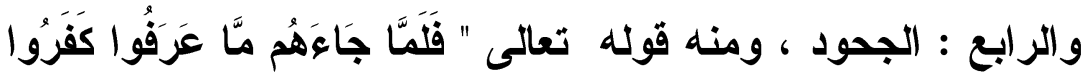

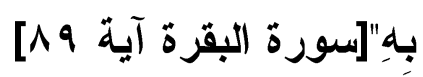

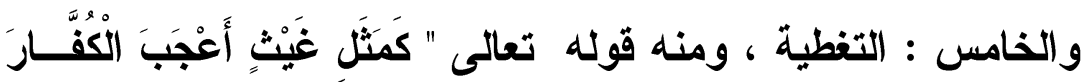

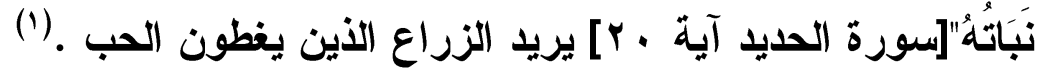

وهنا تتبدى قضية الكفر وأنواعه والحكم عليه وهي قضية تســتحق

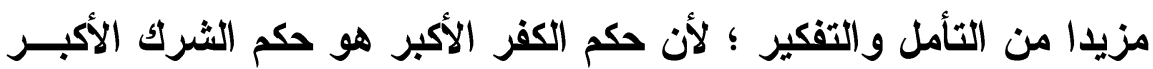

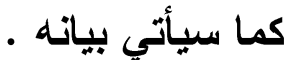

[

(1) نزهة الأعين النواظر في علم الوجوهو النظائر تأليف ابـن الجــوزي ص 14ه، 
كثر التصريح وكثر التأويل وكثر دون كثر :

\section{أولا: كثر التصريتح}

سبق أن بينا أن الكفر في اللغة: " الستر والتغطية "

ويؤكد ذلك لبيد في قوله :

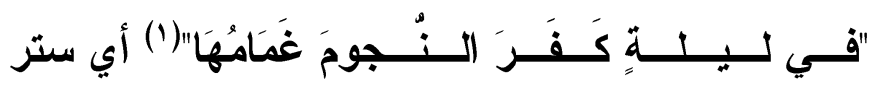

ويرى العلماء أن معنى الكفر في الثرع هو تكذيب النبي شيع مما علم مجيئه به من الاين بالضرورة .

هكذا يقول صاحب المواقف " الكفر هو : عدم تصديق الرسول

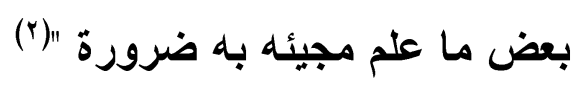

وهنا نجد فكر التفتاز اني أكثر تحديدا في قوله عن الكفر : ( عدم

الإيمان ليشمل الكافر الخالي من التصديق والتكذيب )(זن)

وعلينا أن نفهم هنا من تعريف التفتازاني أن : الكافر اسم لمن لا

$$
\text { إيمان له ـ فهو يشمل: }
$$

- المنافق : من أظهر الإيمان ، وأبطن الكفر •

r- المرتد : من طر أ كفره بعد إسبلامه .

r- المشرك : من قال بإلهين أو أكثر •

(1) البيت من معلقة لبيد بن ربيعة. انظر الموسوعة العلمية للثــر العربـي - فــي

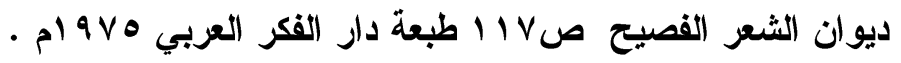

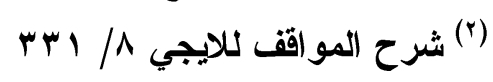

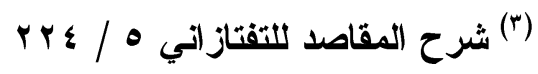


ع - الكتابي : من كان متلينا بدين منسوخ : كاليهودية و النصر انية.

ه- المعطل أو الأهري : من لا يؤمن بإله أصلا .

צ- الزنديق : أسلم لكنه يبطن عقائد تتعارض مع الإسلام .

والكافر : " هو الأي بلغته الاعوة الإسلامية وكان مستعدا لقبولها - بالغ مختار - فأنكرها أو رفضها كلا ، أو بعضا ... والمر اد بالبعض :

ما كان معلوما من الاين بالضرورة " (1) الكفر نوعان : كفر التصريع - كفر التأويل

والتقعيد لكفر التصريح الأي لا خلاف عليه ، وهو ما كان متعلقا بثيء " من العقائد الستة " كمن نطق بكلمة الكفر دون إكراه ـ أو سجد لغير الله ـ أو أنكر معلوما من الاين بالضرورة مع علمه بوجوبه أو أو حرمته كمن أنكر الصلاة أو الصيام أو الزكاة أو استحل حراما كالخمر أو

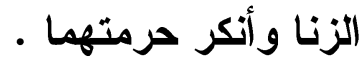

ويقال هنا - كفر التصريح - أيضا من أنكر صريح القرآن، أو كذَّبَ

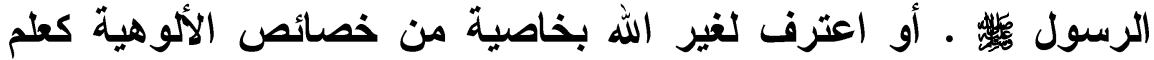
الغيب أو ادعى الألوهية ـ فمن أتى شيئا من ذلك معتقدا خلاف ما جاء به الإسلام فهو كافر كفر تصريح لا خلاف عليه . وتتبدى في النصوص حتمية تكفير المستهزئ بالله ورسوله وكتابه ودينه ونحو ذلك .

(') الإيمان بالله تعالى وملانكته وكتبه ورسله واليوم الآخر و القضاء و القدر 


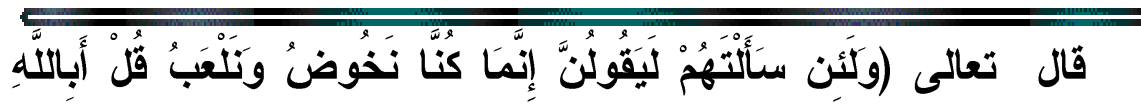

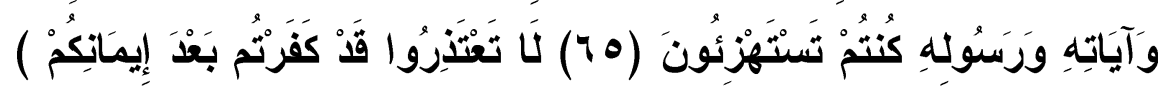

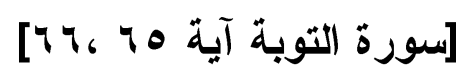

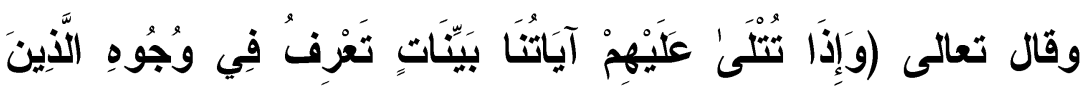

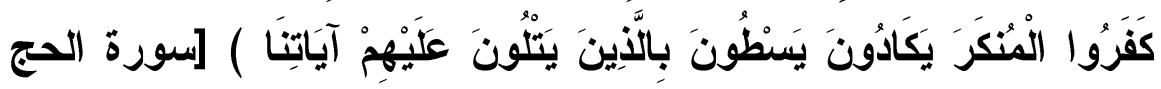

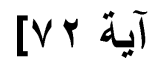

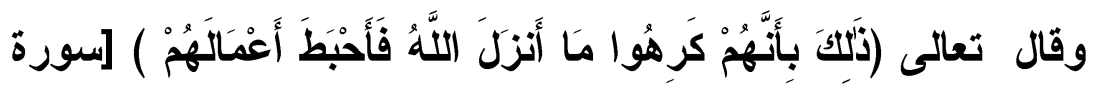

محمد آية 9

وهنا نلاحظ أن النصوص الثرعية حرصت على الاستثناء من ذلتك -

الكفر - الجهل والخطأ والإكراه لوجود العذر، وورود النص قال تعالى

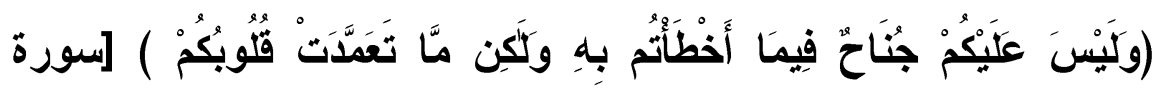

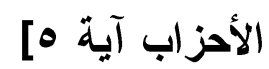

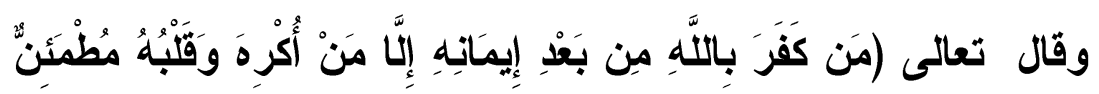

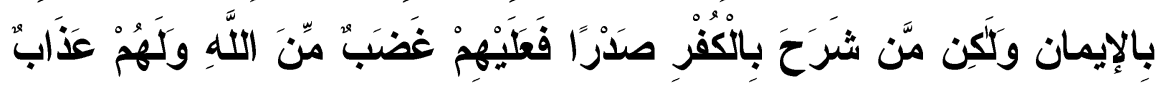

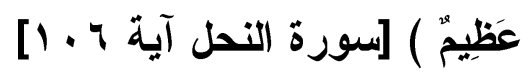

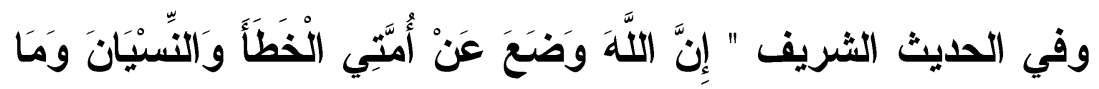

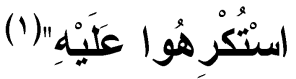

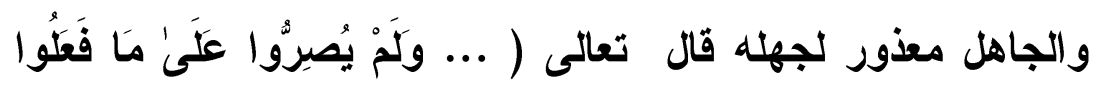

وَهُمْ يَعْلَمُونَ ) [سورة آل عمران آية هـ آ]

(1) أخرجه (بن ماجة في سنته كتاب الطلاق برقم ه ؛ ـ r 
والسياق القرآني هنا يؤكد ضرورة بيان الحق لهؤلاء الجهلاء وتتبيههم عليه، وأقامت الحجة عليهم، بل استتابتهم فإن تابوا وإلا حكم بردتهم • إذا كان قد سبق لهم عقد الإسلام.

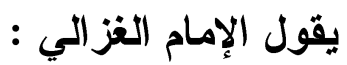

" اعلم أن شرح ما يكفر ، وما لا يكفر يستدعي تفصيلا طويلا ، فاقنع الآن بوصية وقانون : أما الوصية فهي : أن تكف لساتك عن أهل القبلة ، ما داموا قائلين " لا إله إلا الله محمد رسول الله غير مناقضين لها " وأما القانون فهو : أن تعلم أن النظريات قسمان : قسم يتعلق بأصول العقائد ، وقسم يتعلق بالفروع • وأصول الإيمان ثثلاثة :

$$
\text { 1-الإيمان بالله }
$$

Y-الإيمان برسوله

"-الإيمان باليوم الآخر وما عداه فروع "(1)

ويرى الغزالي أنه لا تكفير في الفروع إلا في مسألة واحدة يقول الإمام : " واعلم أنه لا تكفير في الفروع إلا في مسألة واحدة هي : أن ينكر حكما ثبت عن النبي بالإجماع ففيه نظر ، لأن معرفة كون الإجماع حجة قاطعة فيه غموض يعرفه المحصلون لعلم أصول الفقه ، وقد أنكر "النظام" كون الإجماع حجة

(') فيصل التفرقة بين الإسلام والزنادقة. تأليف: الغزالي ص ؟1 
أصلا ، فصار كون الإجماع حجة مختلف فيه ، وأما الأصول الثلاثة، وكل مالم يحتمل التأويل في نفسه ، وتون الإجماعد نقله ولم يتصور أن يقوم برهان على خلافه فمخالفته " كفر " .

كنلك لا يجوز تكفير شخص بعينه ، وإنما يكون الحكم على المبادئ دون الأثخاص؛ لأن سلطة الحكم على الأثخاص ليست للأفراد ، بل

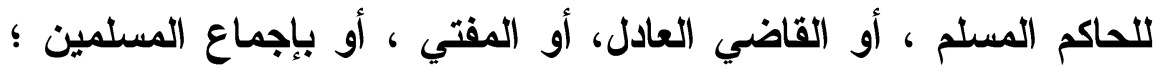

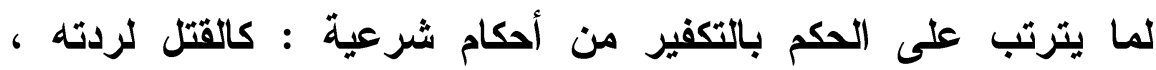
و التفريق بينه وبين زوجه ، وعدم الميراث ، وعدم الصلاة عليه ، وقبره

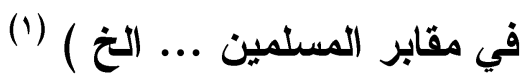

\section{ثانيا: كمر التأويل}

هناك في مجال كفر التأويل المتعلق بالرأي والاجتهاد وسواء في مجال العقيدة أو الثريعة قضايا توقف عندها العلماء كثيرا ، فبعض بلإل قضايا الاجتهاد في مجال العقيدة قد تكون متعارضة مع العياد الفكر الإسلامي وقد يراها بعض العلماء تنكر معلوما من الاين بالضرورة كما كفر الإمام الغزالي الفلاسفة في المسائل الثلاث - قدم العالم و إنكار علم الله بالجزئيات و إنكار البعث الجسماني - في كتابه تهافت الفلا سفة . بينما نجد الحفيد - الوليد ابن رشد - يراها خالية من التعارض مع الإن

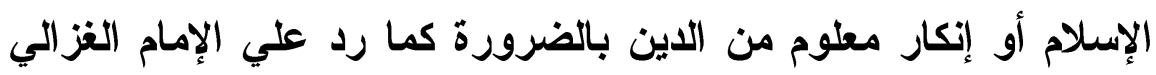
في كتابه - تهافت التهافت - فإذا كان الغزالي كفر فلاسفة الإسلام فإنان ابن رشد حاول الانعتاق من حكم الغز الي على الفلاسفة . (1) فيصل التفرقة بين الإسلام والزنادقة. تأليف: الغزالي صVV 
ونرى في هذين الاتجاهين وغيرهما ما يمكن أن يجرنا إلى أن ننظر ، ونحن لا نجاوز في هذا النظر وجه الحقيقة إذا قلنا .

أولا :- إذا كان صاحب الرأي أو الاجتهاد من المخلصين

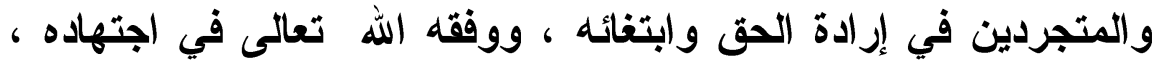

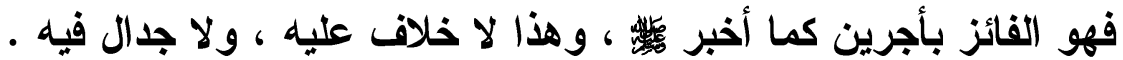
ثانيا :- إذا كان صاحب الرأي والاجتهاد ممن يبتغي الحق وأفرغ

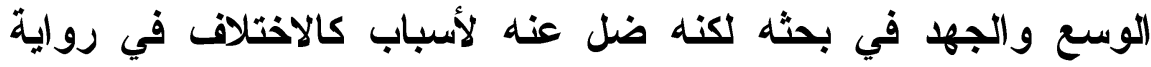
النصوص أو في دلالتها ، أو الرجوع في المسألة إلى رأي دون النص أو لوائه

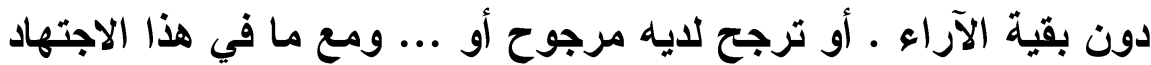
أو الرأي من خطأ أو تزايد أو نقصان لكن صاحبه مأجور وليس معذورا

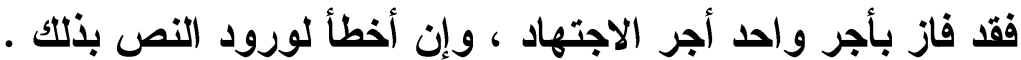

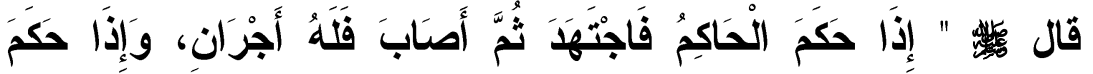

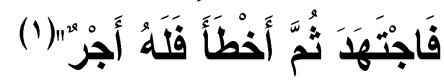

ثالثا :- إذا كان صاحب الرأي أو الاجتهاد يخفي قصده ... فهذا وضعنا أمام عالمه الاخلي الذي لا يعلمه إلا الله تعالى ـ فليس لنا أن الن النال نفتش عن قلوب الناس ، ولا أن نحاسبهم بغير ما استعلن من أمرهم ؛

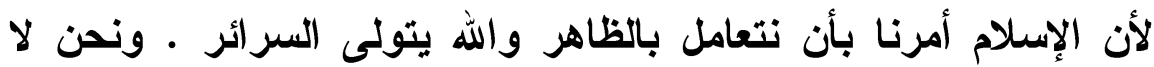

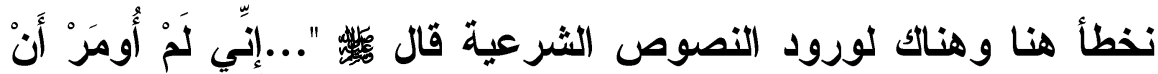
(') أخرجه البخاري في "صحيحه" ( كتاب الاعتصام بالكتاب و الســـة ، بــاب أجسر

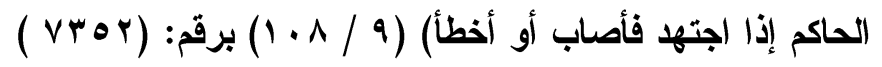




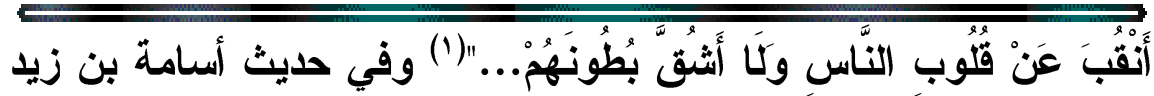

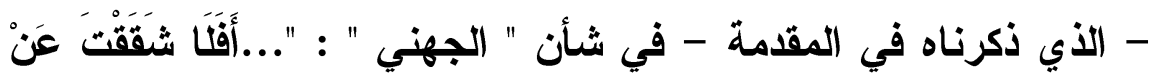

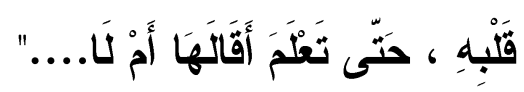

ونعلم في هذا الصدد: أن من دخل الإسلام بيقين ، لا يجوز إخراجه منه إلا بيقين مثله ، وإن اليقين لا يزول بالثك ، أو بالظن .

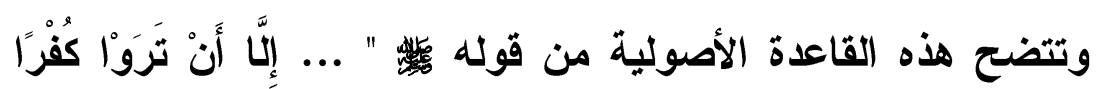

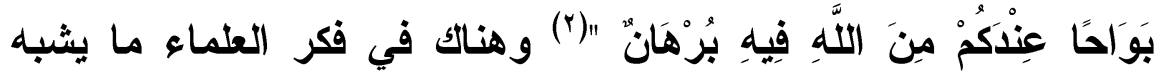
الإجماع على ذلاك . من دخل الإسلام بيقين... - يقول ابن حزم ( كل من ثبت له عقد الإسلام بالنطق بالثهادتين، وبالإيمان بما جاء به

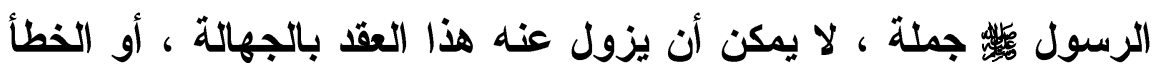
في ملة ( أي عقيدة ) أو عبادة ، أو حكم ما لم تقم الحجة الواضحة عليه ... ثم قال - ابن حزم - وهذا قول إسحاق بن راهويـه ، وداود الظاهري ، وابن ابي ليلى ، وسفيان الثوري ، وقول أصحاب رسول الله فئ

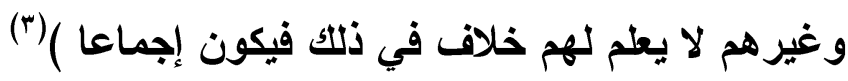
رابعا :- العجيب أنتا نلاحظ أن الأمة تكون أمام مخطط معروف هدفه هدم قواعد الإسلام ، وطمس معالمه ، وتغيير مبادئه وقيمه ،

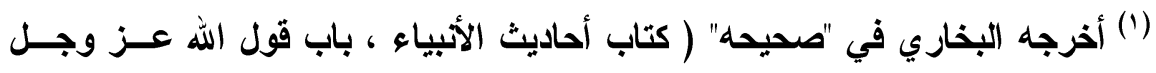

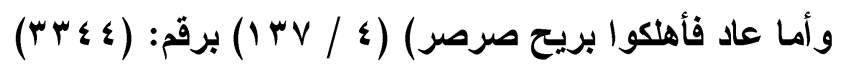

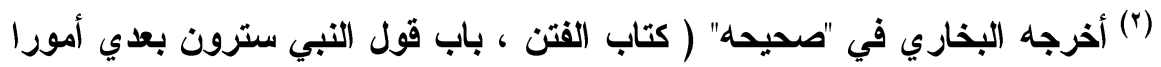

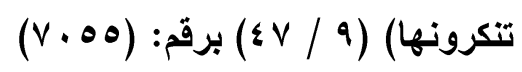

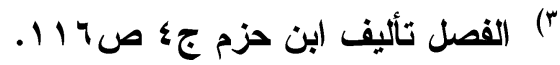


والأعجب أن هذا التيار يتستر بستار الإسلام ـ وينطلق من وراء التأويل

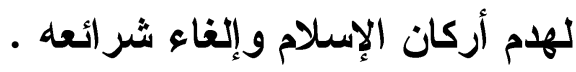

هذا الظلق النازل أثر من أثثار اضطراب عقيدة هؤلاء فلا يلجأ إلى لها مثل هذه الطبائع غير السوية في مناخ كل ما فيه يعتز بقيم انتمائه لأصوله ... إلا كافر . لإعل

خامسا :- أعطى العلماء للانين اجتهاوا في التأويل وقصدوا وجه

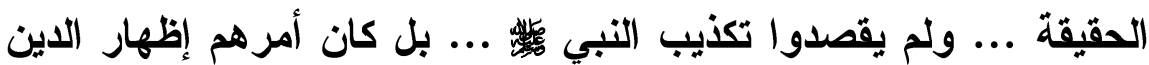
والتدين به ... و التصديق بجميع ما جاء به الإسلام مما هو معلوم من

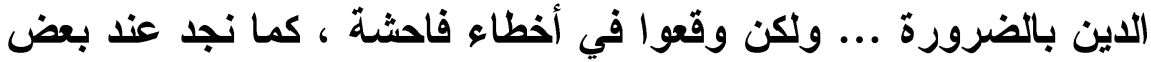
الفرق الإسلامية : كالجبرية أو الجهمية ، أو المجسمة والمثبهة أو

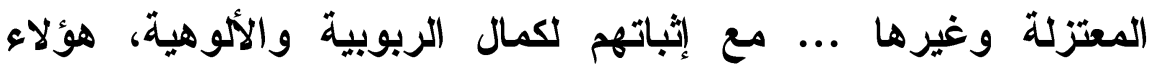
أعطاهم العلماء تعويضا عن اجتهادهم وإبعاد نسبة الظانين عنهم .

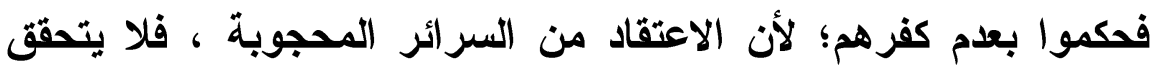

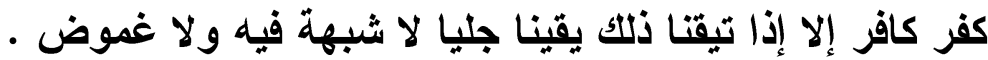
ويبدو موقف العلماء من أهل التأويل جليا : يقول صاحب المواقف " وجمهور المتكلمين ، والفقهاء على أنه لا

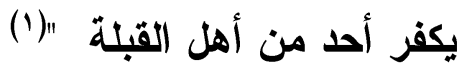
وحكى عن أبي حنيفة رضي الله عنه ( أنه لم يكفر أحد من أهل

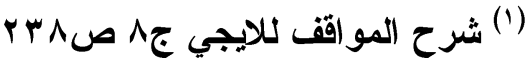

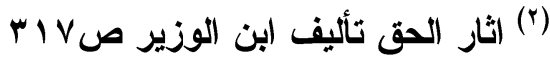




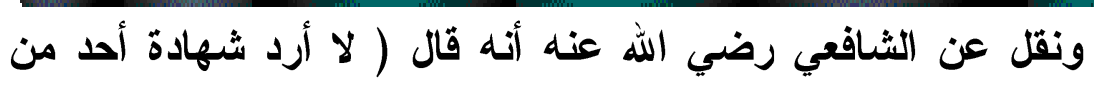

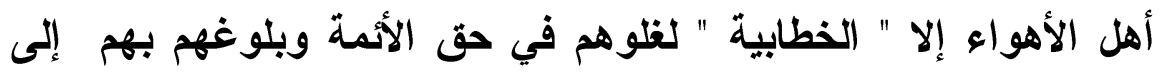

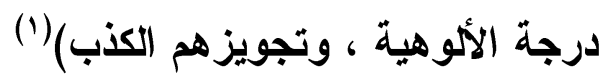

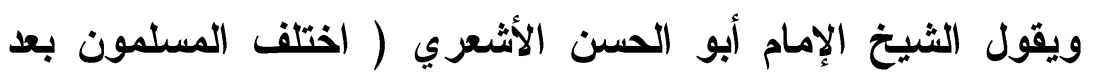

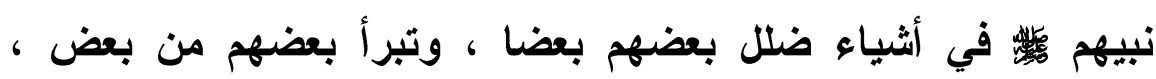

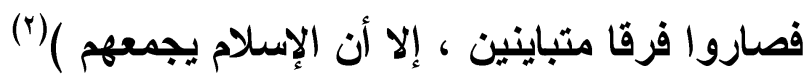

ومن هنا فقد كان أبو اسحاق الإسفراييني - من علماء الأثشاعرة -

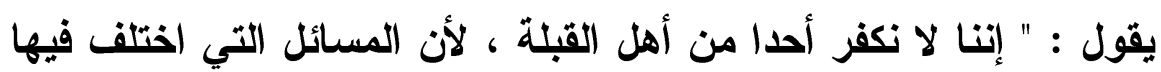

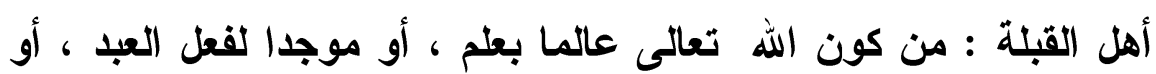

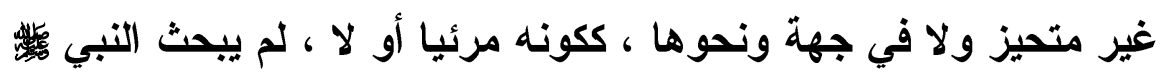

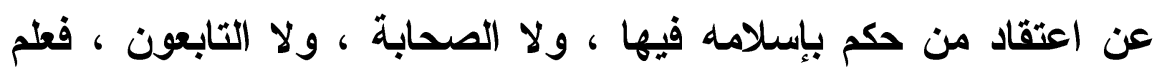

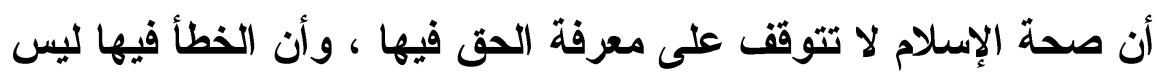

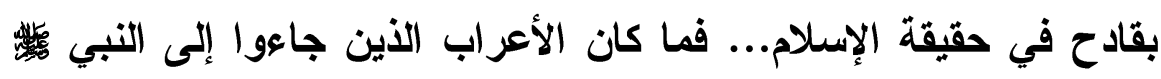

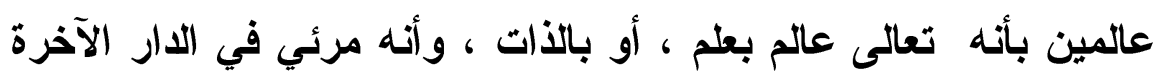

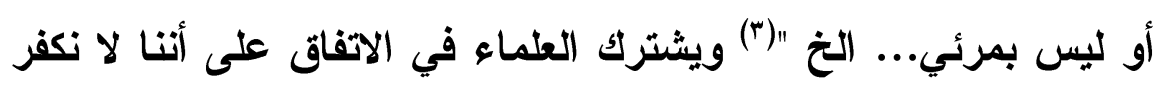

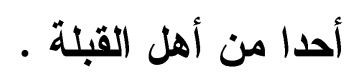

الخطابية : نسبة إلى أبى خطاب محمد بن أبي زينب الأسدي الأجداع مولى بني

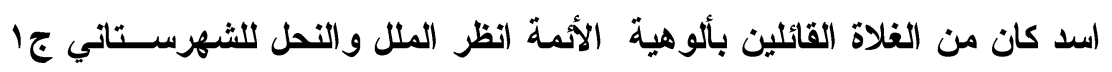

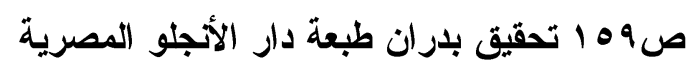

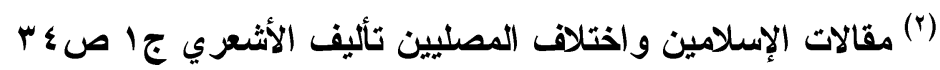

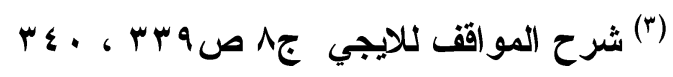


يقول الإمام الرازي وقد وافقه ابن حزم وابن تيمية وغيرهم من الأممة، ولم يجتمع لهم ما اجتمع له من تفصيل. فقد قال " و الأي نختاره: ألا نكفر أحدا من أهل القبلة. والاليل على ذلك أنا نقول : المسائل التي اختلف فيها أهل القبلة ... لا تخلو من أمرين : إما أن تتوقف صحة الأل

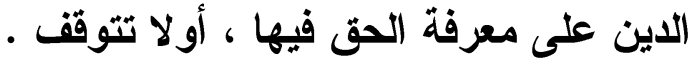
والأول باطل : لأهد لو كاتت معرفة هذه الأثثياء من الادين لكان من الواجب على النبي

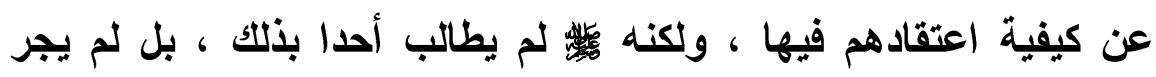

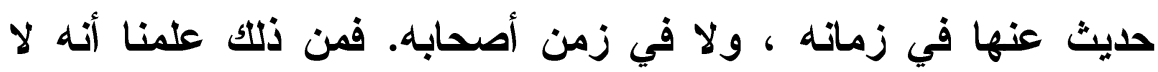

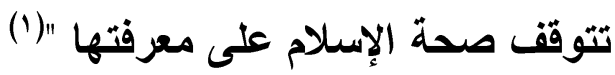
ويعود الرازي إلى تأكيد ما اختاره - ألا نكفر أحدا من أهل القبلة -

بقوله " لو كان شيء من ذلك - المسائل التي اختلف فيها أهل القبلة يتوقف عليه صحة الدين ، لكان من الواجب على النبي لئدي أن يبينه

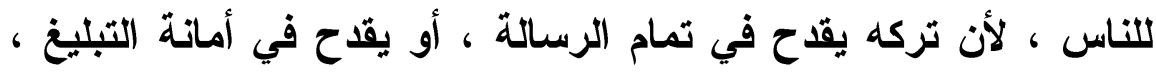

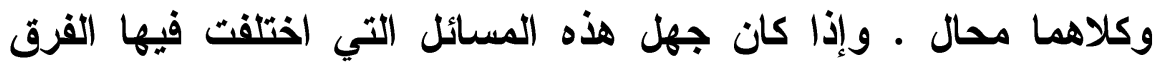
الإسلامية ، أو الخطأ فيها غير قادح في حقيقة الإسلام فإن ذلك يقتضي

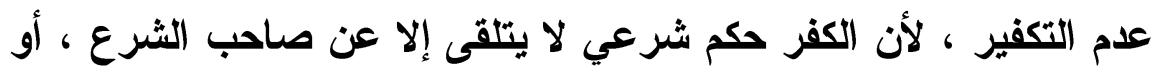

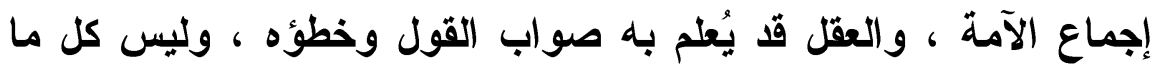

(1) ما لا يجوز الخلاف فيه تأليف الثيخ عبد الجيليل عيسى ص99 11 . 
كان خطأ العقل يكون كفرا ، ولو كان كل خطأ كفرا ما نجا منه إلا

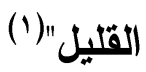

والإمام الطحاوي يؤكد هذا الفهم - ألا نكفر أحدا من أهل القبلة -

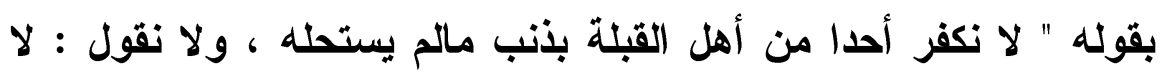

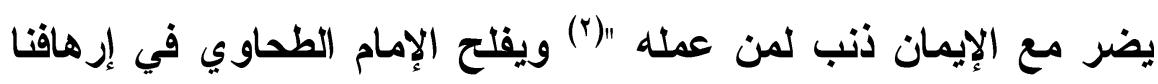
بمنطقية الربط والتعليل حين يشير إلى أن " العبد لا يخرج من الإيمان إلا لإي الإمي

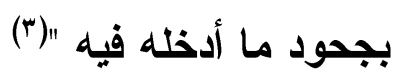
ويلوح في فكر ابن حزم جودة واضحة في قوله " ... وأما كفر المجتهين في الفتوى فقول ساقط لا وجه له، لأن جميع الصحابة قد اجتهوا في الفتوى واختلفوا ، فمن كفر المجتهدين في الفتوى لزمه أن

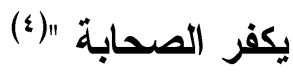
كفر دون كفر - كفرا أكبر وكفرا أصغر- ويقبض العلماء هنا من من خلال النصوص الشرعية على خصائص فكرية عقدية بارزة: من اقتدار واضح على تحديد كفر دون كفر

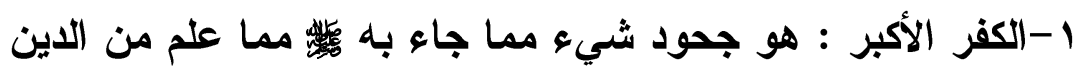
بالضرورة ، أي ثبت بكتاب الله ، وبالسنة المطهرة ، أو أجمعت عليه

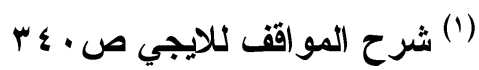

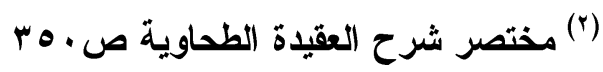

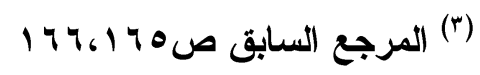

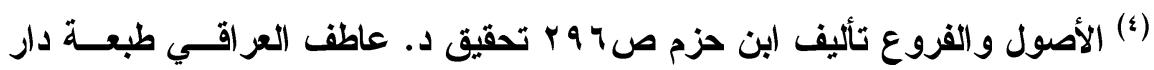

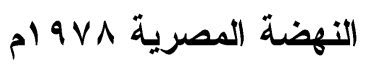




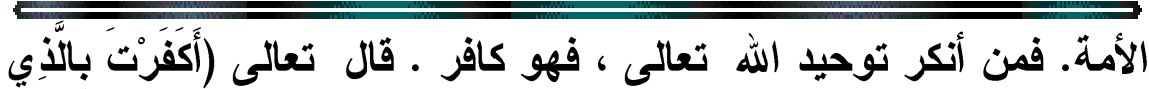

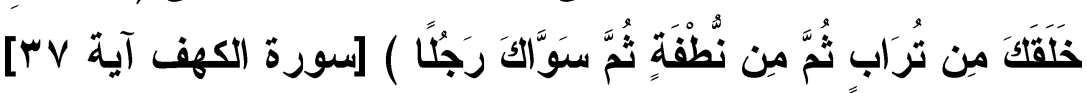
ومن أنكر توحيده " جل وعلا " فهو كافر .

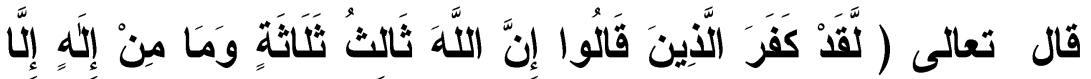

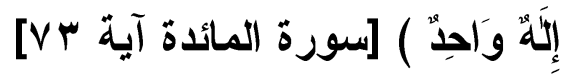

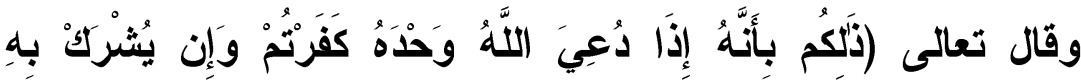

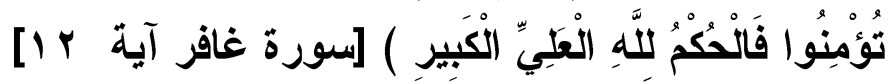
ومن أنكر رسالة الخاتم

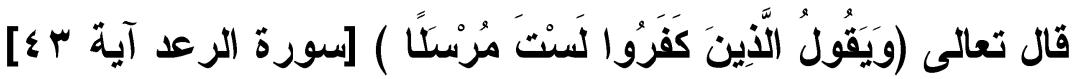

$$
\text { ومن أنكر كتابه - القرآن الكريم - فهو كافر }
$$

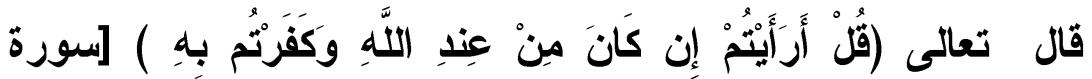

$$
\text { الأحقاف آية • 1] }
$$

إن الآيات القرآنية الكريمة التي تتحدث عن " الكفر الأكبر " أكثر الكر الكرد

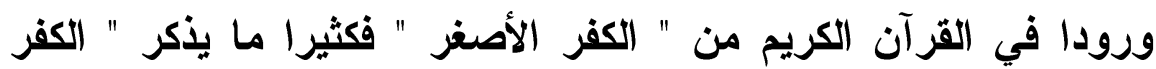

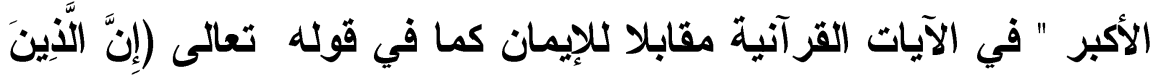

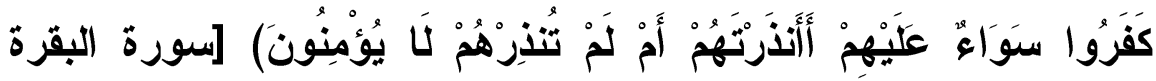

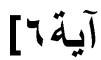

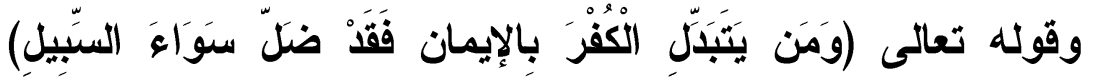

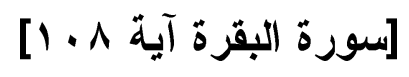




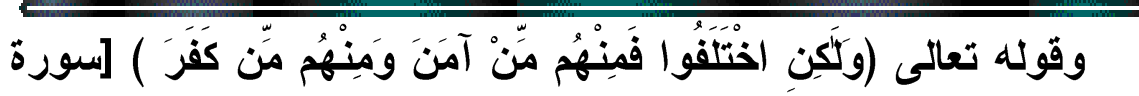

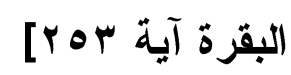

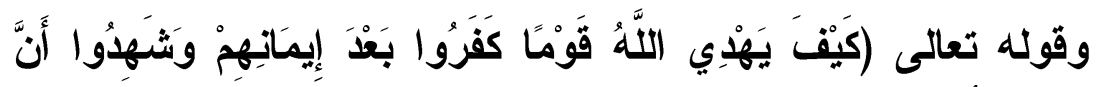

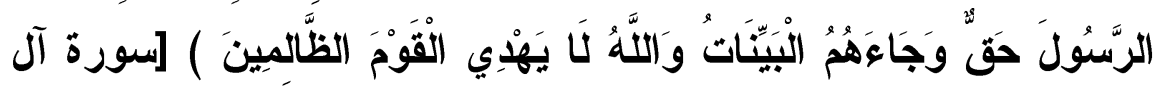

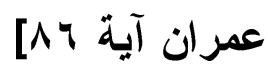

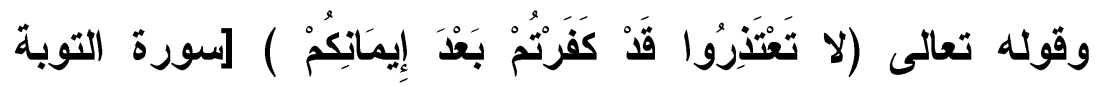

[آية

ويتبدى بوضوح من خلال النصوص الثرعية أن للكافر حكما في

الآخرة وأحكاما في الانيا :

فحمم الكافر في الانيا - والحكم بالكفر لا يكون إلا بعد إسلامه -

يترتب عليه أمور :

( ا - لا تحل زوجته له ، أعني لا تبقى في عصمته

r- لا ولاية له على أولاده ؛ لأنه لا ولاية لكافر على مسلم

r- لا يرث ، ولا يورث ؛ لاختلاف الاين

$$
\text { ع- لا تحل ذبيحته }
$$

ه- لا يصلى عليه ، ولا يدفن في مقابر المسلمين .

أما حكم الكافر بعد إسلامه أنه يخلا في النار )(')

r - الكفر الأصغز

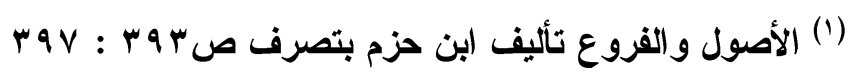


بدا وضَحُ الصبح أن الكفر الأصغر أو ما يسمى بالكفر المجازي ،

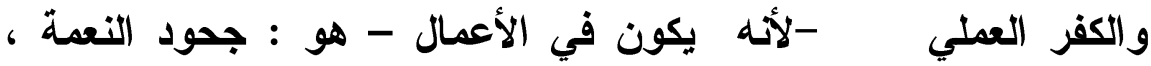
وعدم شكر المنعم سبحانه و تعالى ويبدو الفرق شاسعا وكبير ابين طبيعة الكفر الأكبر والأصغر فالكفر الأكبر يصل بنا إلى ذروة التوتر والاحتدام في الأحكام الانيوية و الأخروية التي ذكرناها سلفا ـ أما الكفر الأصغر فلا يترتب عليه ذلك لأنه من قبيل المعاصي فقد جاء في القرآن الكريم

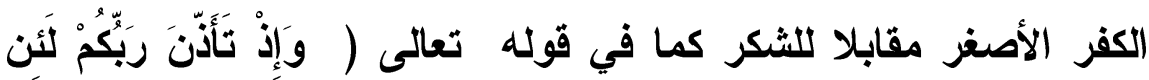

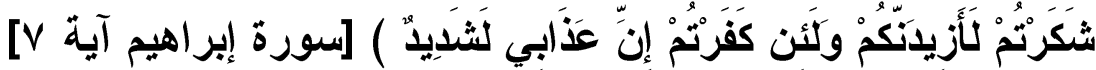

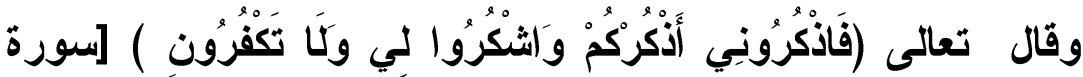

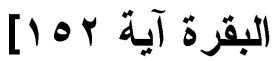

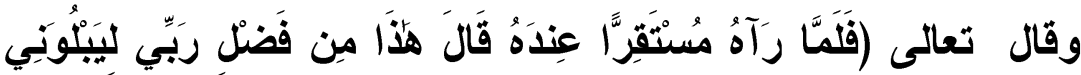

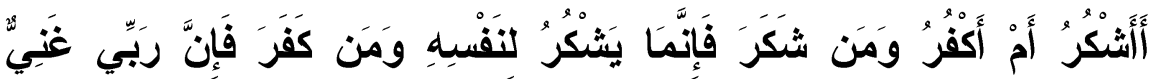

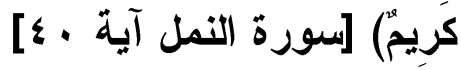

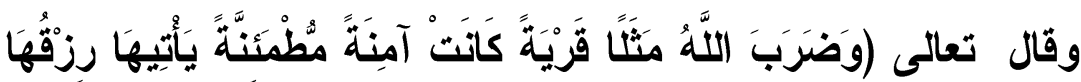

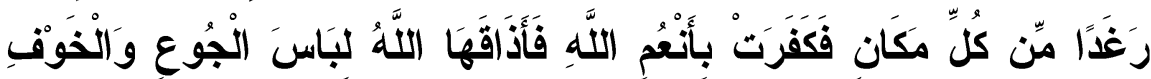

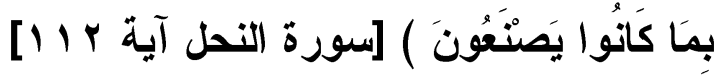
ويمكن أن نلاحظ أن اليهود عندما حاولوا إثارة الفتنة بين الأوس

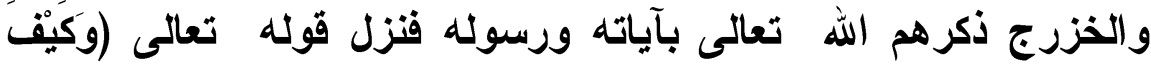

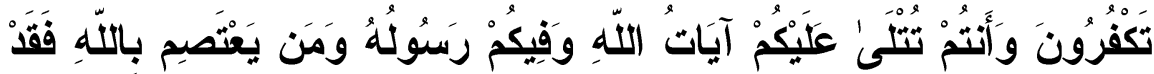

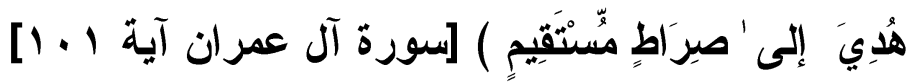


وقد فطن العلماء أيضا إلى أن الثرع سمى بعض الذنوب كفرا تنفيرا

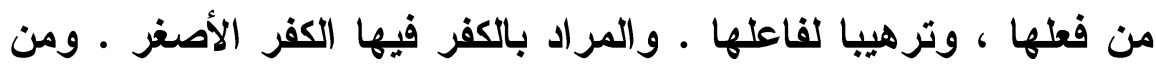

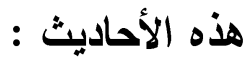

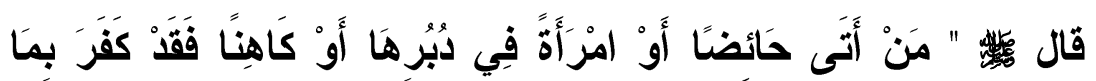

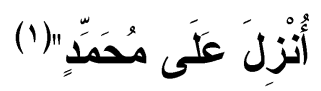

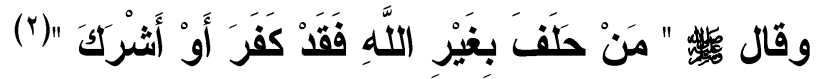

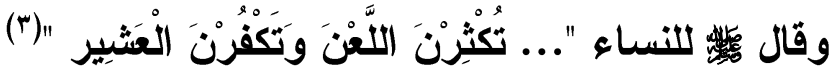

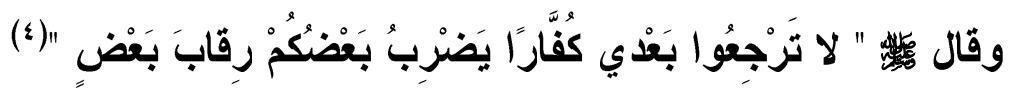

كذللك يمكن أن نلاحظ أن بعض الأحاديث النبوية تذكر أن فاعل بعض الأنوب لا يلخل الجنة أو أنها عليه حرام مما قد يفهم منه انه كفر أكبر. لكن هذه الأحاديث وردت للتنفير من تلكك الأنوب ، فهي من باب الكفر لألها الأصغر من هذه الأحاديث : الأك وردث قوله

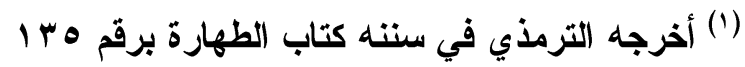

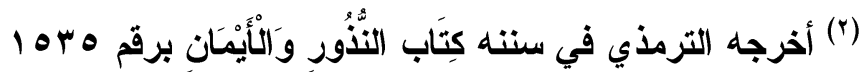

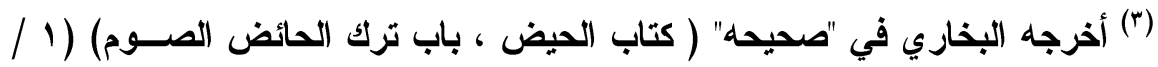

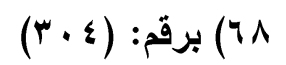

(i) أخرجه البخاري في "صحيحه" ( كتاب العلم ، باب الإنصات للعلــاء) (1 / هץ)

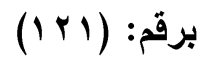

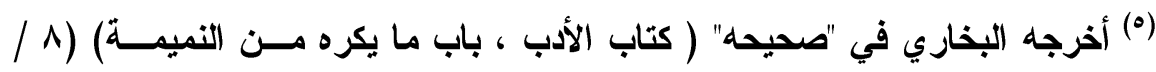
(IV 


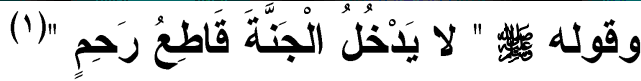

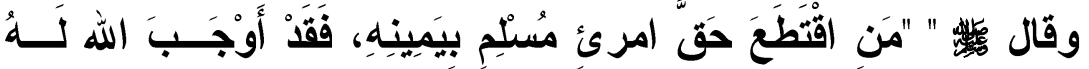

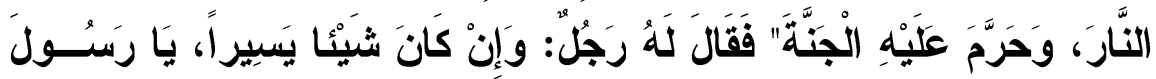

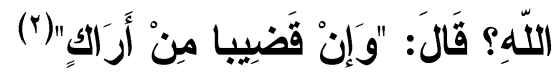

وقال

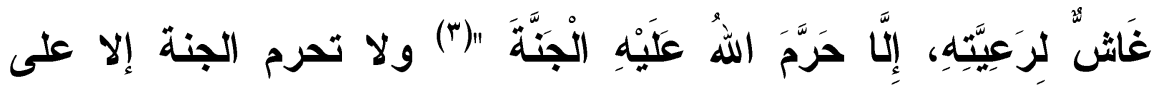
• الكافرين

إن تأمل هذه النصوص الثرعية التي يفيد ظاهرها الكفر لمجرد المعصية لإتياتها مع وجود النهي عنها ـ قد يقال هنا إن كثيرا من النصوص الثرعية دالة على الكفر ويقحمها الكثيرون في الكفر دون التفريق بين الكفر الأصغز - جحود النعمة ، وعدم شكر المنعم عليها والكفر الأكبر - جحود شيء مما جاء به الخاتم مما علم من الاين بالضرورة - كما وضحنا آنفا ـ ولعلنا لا نخطئ التعليل في دراستنا للكفر الأصغر والأكبر إذا قلنا ـ إن الأساس الأي بني عليه التفريق بينهما قوله

(1) أخرجه مسلم في "صحيحه" ( كتاب البر والصــلة والآداب ، بــاب صــلة الـرحم

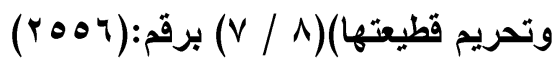

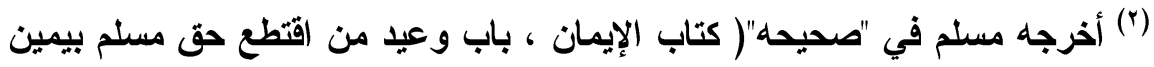

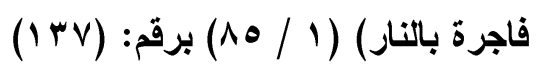

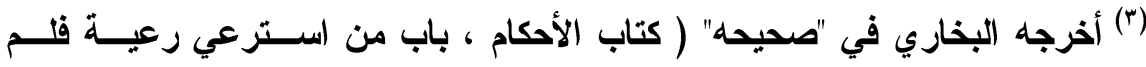

$$
\text { (V) ( }
$$




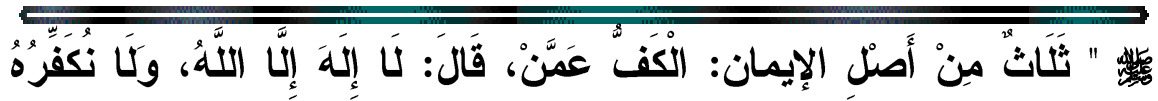

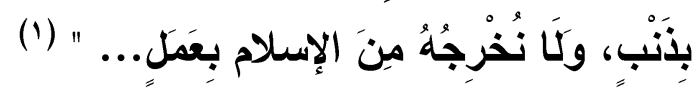
ويخطئ من قد يظن أن النصوص السابقة والآتية تفيد الكفر الأكبر •

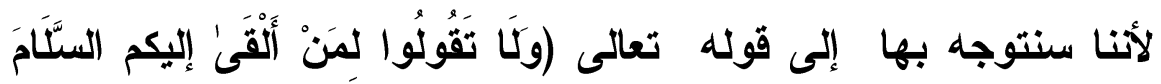

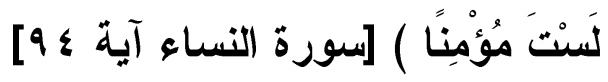

ومن النصوص التي يفيد ظاهرها الكفر الأصغر لمجرد المعصية ما يأتي :

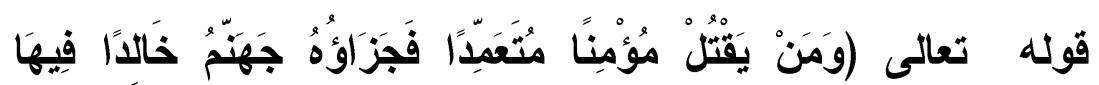

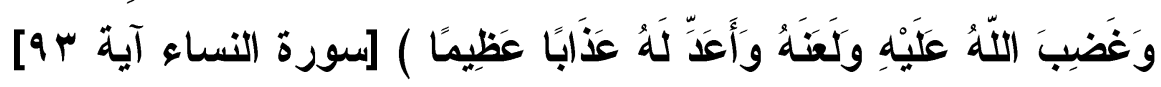
والعلماء يحملون الآية الكريمة على المستحل للقتل ، وهو كفر أكبر بإجماع الأمة ـ أما القتل مع العلم بحرمته كفر أصغر

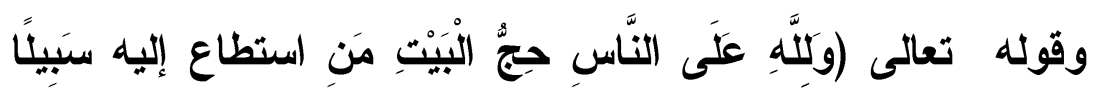

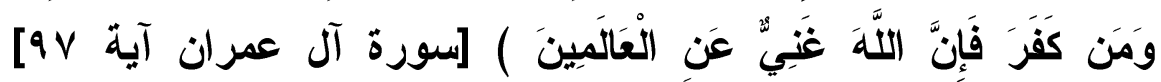

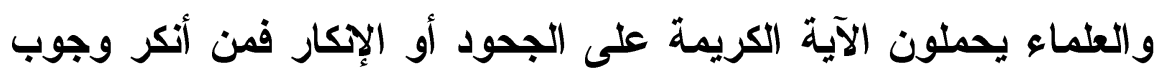
الحج فهو كافر لإككاره معلوما من الاين بالضرورة

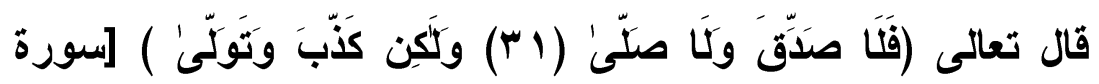
القيامة آية اس :

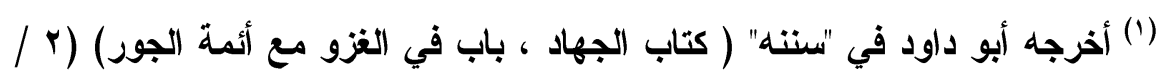
צr 


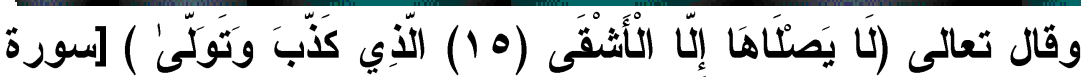

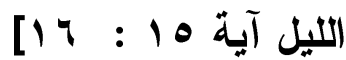

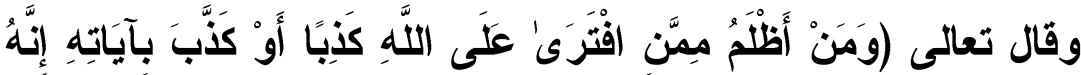

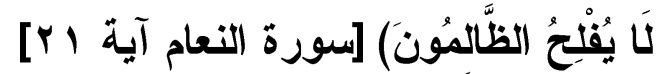

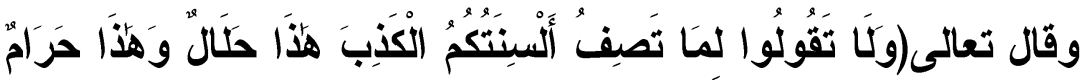

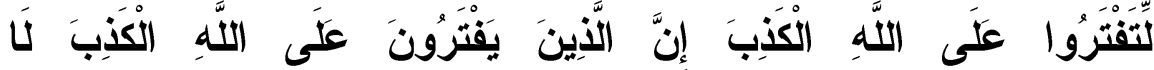
يُقْلِحُونَ (1)

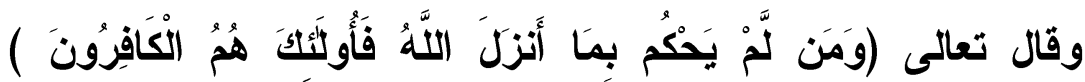

[سورة المائدة آية ؟ ؟] ويحمل العلماء الكفر على المعتقد خلاف ما أنزل

الله تعالى

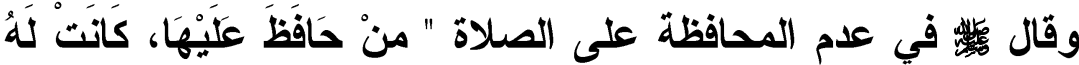

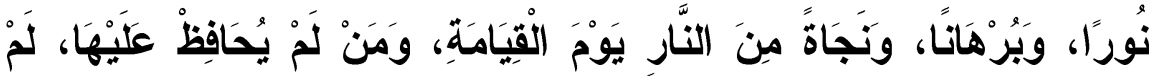

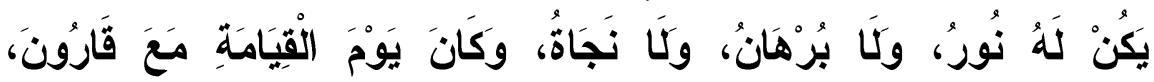

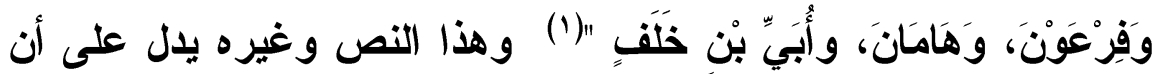
ترك الصلاة كفر ... مما حدا بجماعة من السلف للقول بتكفيره فقد ورد عن شقيق بن عبد الله أنه قال : " كان أصحاب محمد لئس لا يرون شيئا

من الأعمال تركه كفر غير الصلاة "(ץ)

وللجمهور آراء جهيرة وحجج قوية في أن حجة المُكفر ظاهر النص

إلا أن ظاهر النص معارض وحجج الجمهور كثيرة نذكر منها :

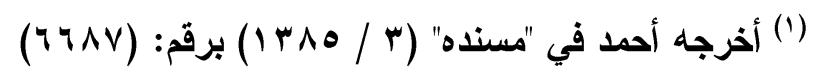

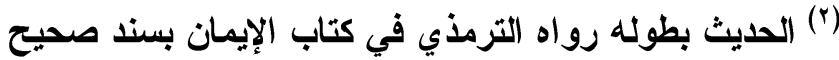


أولا :- أن هذه النصوص وأهثاها هتروكة الظاهر :

يقول الإمام النووي في شرح الحديث :

" وأما تارك الصلاة فإن كان منكرا لوجوبها فهو كافر بإجماع المسلمين خارج عن ملة الإسلام ، إلا أن يكون قريب عهد بالإسلام ، ولم يبلغه وجوب الصلاة ، وإن كان تركه لها تكاسلا ، مع اعتقاده بوجوبها ،

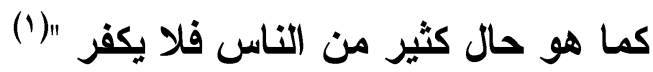
واختلف الفقهاء في الحكم على تارلك الصلاة ولكن الجميع قالوا بعدم

فذهبت الجماهير من السلف والخلف، منهم مالك والثافعي إلى أنه لا يكفر بل يفسق، فإن تاب وإلا قتل حدا كالزاني المحصن، ولكنه يقتل بالسيف. وذهب جماعة من السلف إلى أنه يكفر، وهو مروي عن علي بن أبي طالب رضي الله عنه، وهو إحدى الروايتين عن أحمد بن حنبل، وبه قال عبد الله بن المبارك وإسحاق بن راهويه، وهو وجه لبعض أصحاب الشافعي. وذهب أبو حنيفة وجماعة من أهل الكوفة والمزني صاحب الثافعي إلى أنه لا يكفر ولا يقتل بل يعزر ويحبس حتى يصلي"(؟)

(') شرح النووي على مسلم. تأليف : النووي - أبو زكريا محي الاين بـن شــف

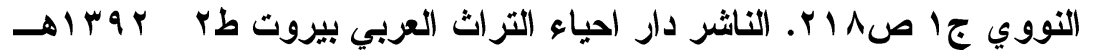
(r) بستان الأحبار مختصر نيل الأوطار المؤلف: فيصل بن عبد العزيز بن فيصل ابــن

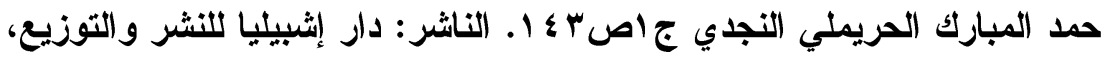

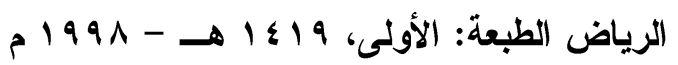


ثانيا :- حجه جمهور العلماك في عدم تكفير تارك الصلاة هم

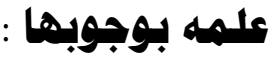

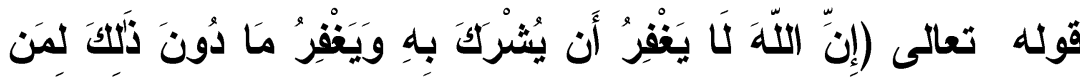

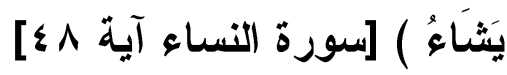

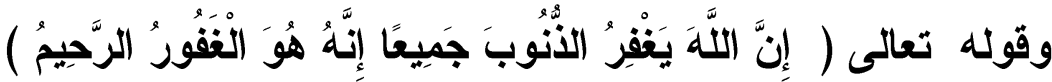

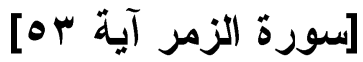
وهنا تلوح الأحاديث النبوية الثريفة المؤكدة للآيات القرآن الكريم بكل ما تنحني عليه من معان

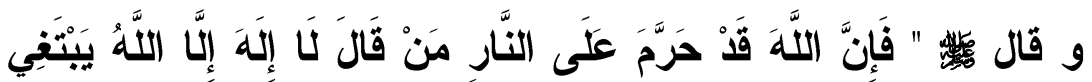

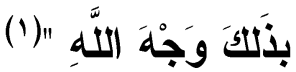

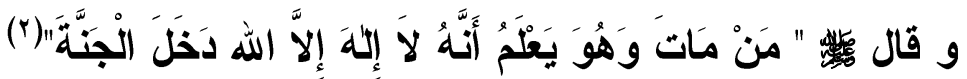

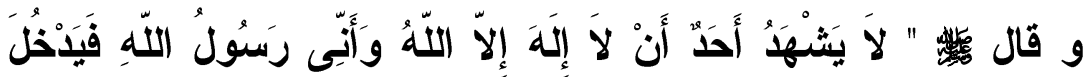

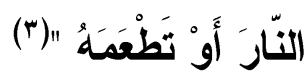

(1) أخرجه البخاري في "صحيحه" ( كتاب العلم ، باب متى يصـح ســاع الصــير)

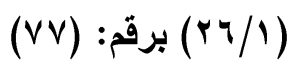

(") أخرجه مسلم في "صحيحه" ( كتاب الإيمان ، باب من لقي الله بالإيمان وهو غيــر

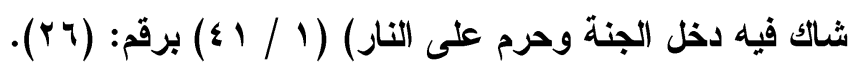

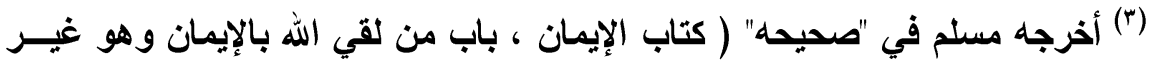

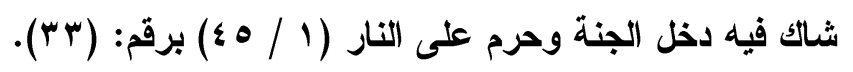




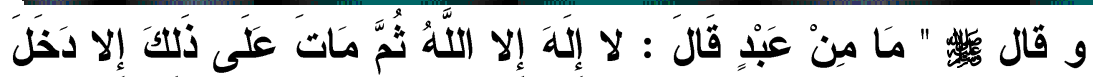

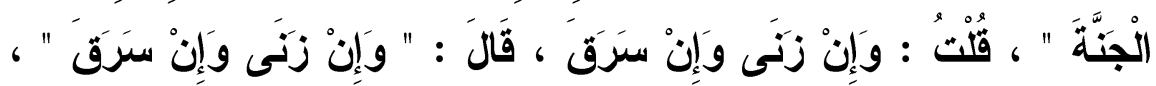

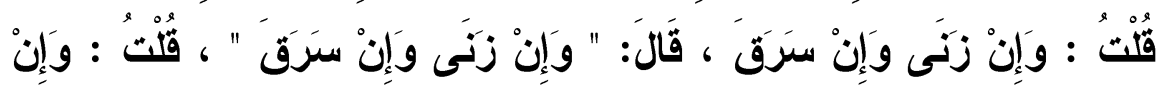

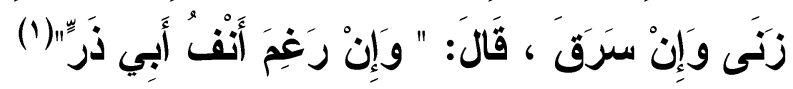

ولقد أحسن جمهور العلماء فهم ألفاظ التكفير الواردة في حق تارك

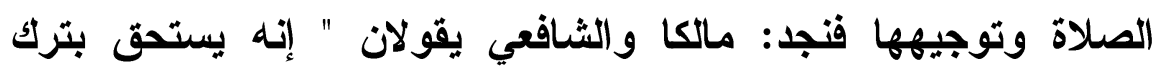

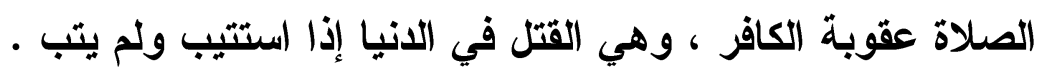

وقد يؤول به ترك الصلاة إلى الكفر ، لأكه من واظب على ترك

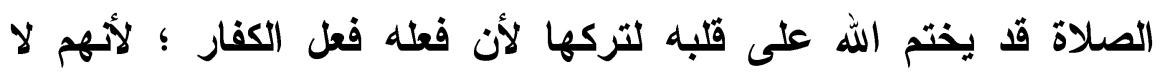

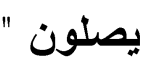

وقيل " إن ذلك محمول على المستحل لتركها "(†)

ويرهف ابن حزم والرازي قلوبنا في قضية ترك المسلم الصلاة يقول

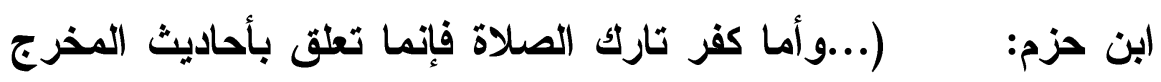

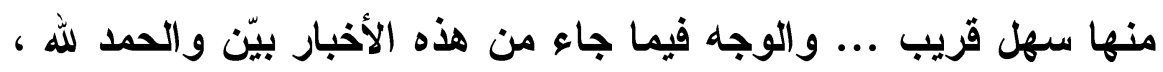

وهو أن كلامه

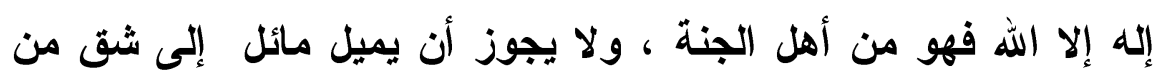

(1) أخرجه البخاري في" صحيحه "(كتاب الجنائز ، باب في الجنائز ومسن كسان آخـر

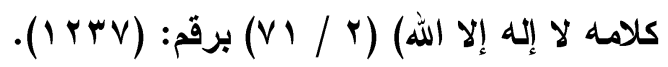

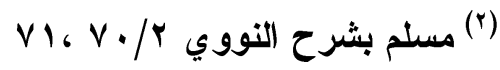


الحديث دون الأخر ، بل لا بـ من استعمالها جميعا ... وعلى ذلك يحمل

$$
\text { (التكفير على الجحد دون غيره )(") }
$$

ويرى الإمام الرازي "رحمه الله" : أن هذه النصوص وغيرها لا تدل دلالة قاطعة على كفر من اعتقد شرعيتها ، لأمور منها : ( أن النصوص الثرعية لم توضع للعموم • بل هي للجنس تحتمل العموم كما تحتمل الخصوص .

r - ولو فرضنا أن هذه الصيغ تفيد العموم ، فهي لا تفيده قطعا ... لأن الناس كثير ا ما يعبرون عن الأكثر بلفظ الكل على سبيل المبالغة . r-ولو فرضنا القطع في إفادة النصوص الشرعية الجميع ، فكان لابد من شرط عدم وجود المخصص ، وأكثر عموميات القرآن الكريم

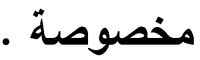

ع-ولو فرضنا عدم وجود المخصص ، فآيات العفو مخصصة لها . والخاص مقدم على العام •

والآيات القرآنية الدالة على العفو كثيرة نذكر منها :

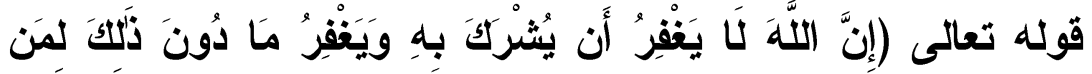

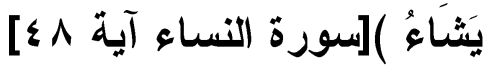

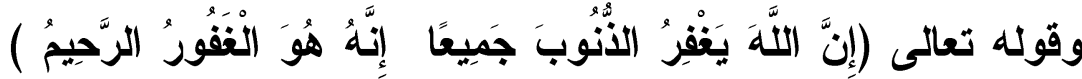

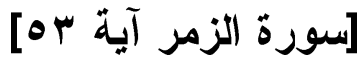


مجلة كلية الكراسعات الرإسلامية والعريبة بنات بنهي سويفعالعذى العاشر

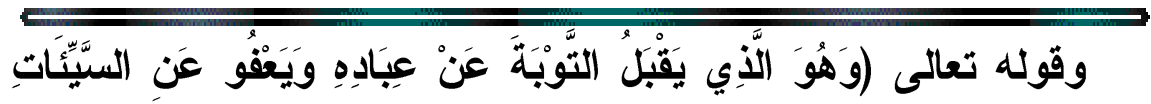

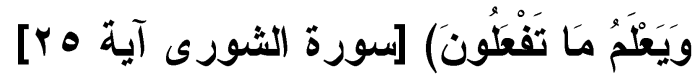

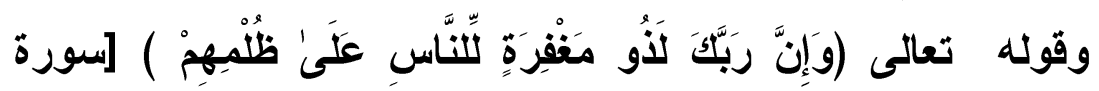

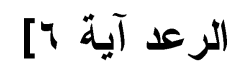

ه-عموميات " الوعيد " معارضة بعموميات " الوعد " والوعد مقدم

وراجح لأسباب أ- الوفاء بالوعد داخل في باب الكرم لأنه - صفات

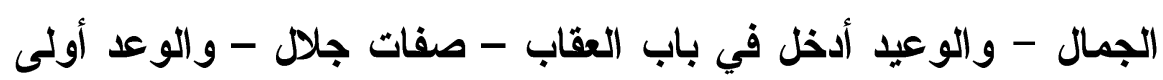

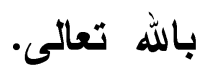

ب- العديد من النصوص الثرعية وردت بالأخبار بأن رحمته تعالى

سبقت غضبه .

צ-يمكن حمل هذه العموميات على الكفار الأين نزلت الآيات

(1) (1) (1)

ونستطيع أن نقول: إن هذه العموميات قد تفيد كفر المعصية لا كفر

الثرك بالله تعالى. فيمكن حمل ما ورد من النصوص التي تفيد الكفر لمجرد معصية على كفر المعصية أو كفر نعمة المنعم لا كفر الشرك فقد

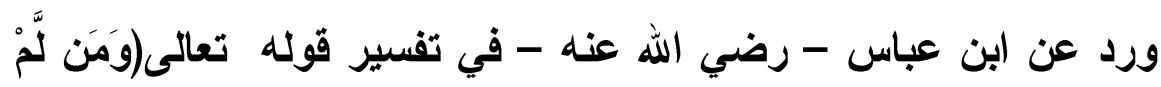

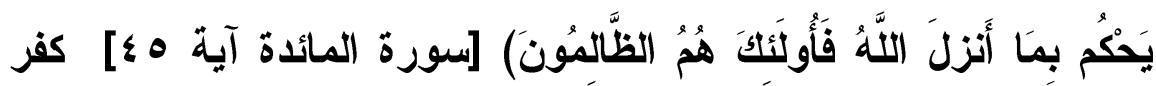

(1) مفاتيح الغيب أو التفسير الكبير ـ تأليف "فخر الدين الرازي" - أبو عبد الله محد

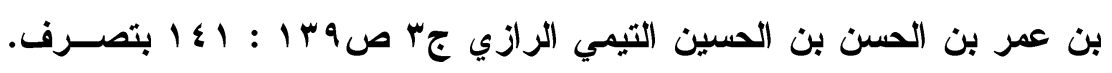

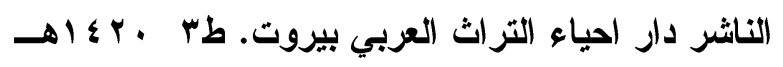


دون كفر، وظلم دون ظلم، وفتق دون فسق، فهو ظلم أكبر، عند

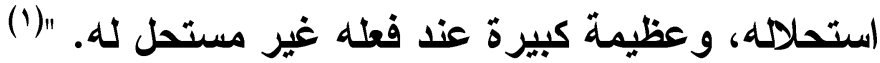

وبدهي أن هناك كفرا أكبر يخرج صاحبه من الملة كالسجود لغير الله

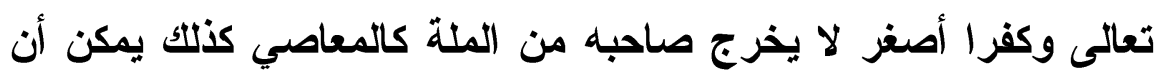
نلاحظ أن هناك نفاقا أكبر ونفاقا أصغر فالنفاق كالكفر الأكبر: مخرج من الملة . و النفاق الأصغر : غير مخرج من الملة . ولعله قد بات واضحا أن النفاق الأكبر: نفاق اعتقاد، والنفاق الأصغر نفاق عمل

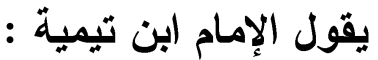

" النفاق كالكفر: نفاق دون نفاق، ولهذا كثيرا ما يقال: كفر ينقل من

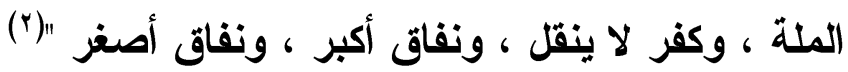

والنفاق الأكبر : إظهار الإسلام وإخفاء الكفر ، وهو يتعلق بالاعتقاد

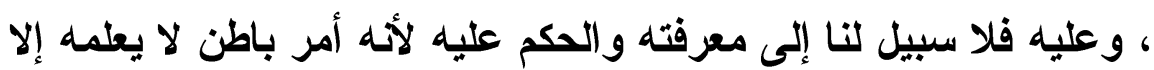
الله تعالى ، والإسلام أمرنا بأن نتعامل مع الظاهر والله يتولى السرائر . وصاحب هذا النفاق كافر عند الله تعالى . وصاحبه في الدرك

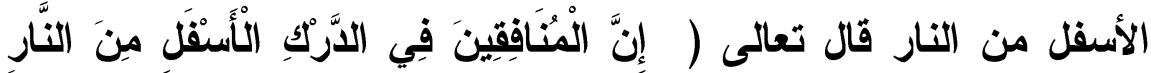

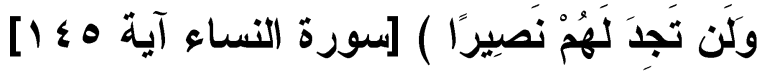


وصاحب هذا النفاق الأكبر مسلم عندنا : تجري عليه أحكام المسلمين

لتظاهره بالإسلام ، وعدم معرفتنا بباطنه الأي يحمل الكفر •

والنفاق الأصفر : يتعلق بالعمل دون الاعتقاد. وهو إظهار الخير وإخفاء الشر في القول أو العمل أعني فعله وقوله - علاتيته - تخالف

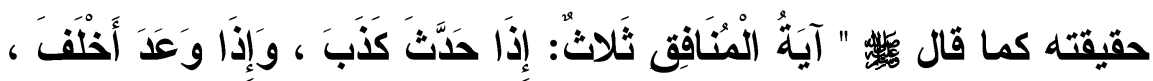

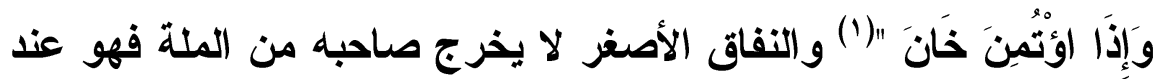
الله تعالى مؤمن وعندنا وإن كان مرتكبا للمعاصي • والمعاصي مع سلامة الاعتقاد ليست شركا ولا كفر ا.

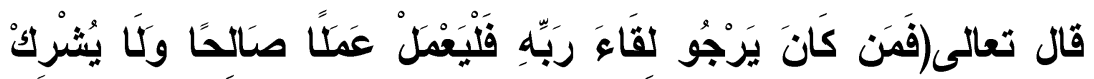

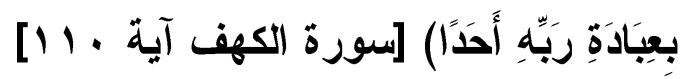

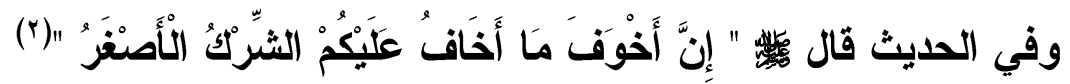
ثالثا :- تكفير هن لم يكفر الكافر : نحن هنا إذن مع نصوص شرعية قطعية الثبوت والالالة وردت في شأن : المشركين، والملحدين ، واليهود ، والنصارى ... ومن في حكمه ولهذا كان إجماع الأمة على كفرهم ، أوردتهم عن الإسلام .

(1) أخرجه البخاري في "صحيحه" ( كتاب الإيمان ، باب علامة المنــقق) (1 / 1 (1) برقم: (rr) (بr)

(r) أخرجه أحمد في "مسنده")(مسند الأنصار رضي الله عنه ، حليث محمود بن لبيد

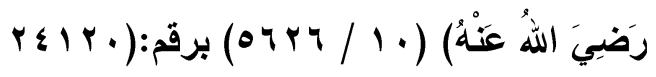


فمن علم أن النصوص الشرعية قطعية الثبوت والدلالة على كفرهم ثم حكم بعدم كفرهم ، فهو منهم - كافر - لأنه أنكر معلوما من الدين

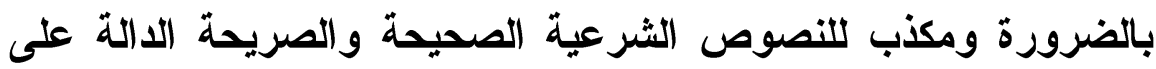
كفرهم ـ ومنكر لما أجمعت عليه الأمة .

أما من لم يرد في كفره نص شرعي قطعي، أو أختلف العلماء المعتد بعلمهم وعدالتهم وورعهم ... في كفر أعني من لـ يكفر كفرا صريحا لم يجز العلماء تكفيره وذلك لقيام الثبهة ، ووجود الاحتمال كما سبق أن ذكرنا في كفر التأويل . ونستطيع أن نقول إن من كفر أخاه المسلم متعمدا غير متأول فإن

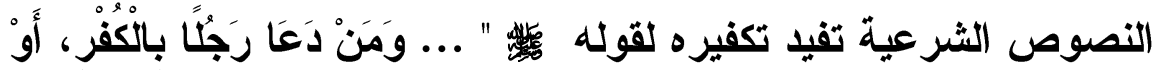

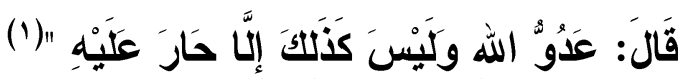
ويتبدى حس القبض على قضية من كفر أخاه متعمدا غير متأول في قول الإمام النووي : " أما من كفر أخاه متعمدا غير متأول كما في "من من عن كفر أخاه..." فإن هذا الحديث مما عده بعض العلماء من المشكلات : فإن مذهب أهل الحق : أن المسلم لا يكفر بالمعاصي ، وهذا منها ، فقيل في تأويله وجوه : الأول : أنه محمول على المستحل لألك ، وبهذا يكفز الثاني : أنه محمول على الخوارج • (') مسلم في "صحيحه"( كتاب الإيمان ، باب بيان حال إيمان من رغب عَنْ أبيه وهو

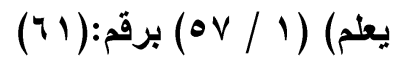


الثالث : أن المعنى رجعت عليه نقيصته لأخيه - تكفيرهالرابع : أن تكفيره محمول على أنه يؤول به إلى الكفر

الخامس : أن معناه : فقد رجع عليه تكفيره ، وليس الراجع عليه هو حقيقة الكفر · بل التكفير لكونه جعل أخاه المسلم كافرا. فكأنه كفر نفسه ، إما لأنه كفر من هو مثثله ، وإما لأنه كفر من لا يكفره إلا كافر

يعتقد بطلان الإسلام "(1)

وفكر الإمام النووي - رحمه الله - مضامينه أقرب إلى معقولية التحقق الإسلامي، ومن هنا فرض علينا أن ننظر في قضية تكفير المسلم بالمعاصي وذهب في تأويلها إلى وجوه .

والأي أختاره وأميل إليه وأقول به هو قول البخاري والغزالي وغيرهما وهو " أن الحديث ورد فيمن تعمد التكفير دون المتأول في التكفير ؛ لأنه لما كان معتقا الإسلام كان قول المكفر " إنه كافر " قول بأن الأي هو عليه كفر ، والأي هو عليه كفر ، والأي هو عليه دين الإسلام ، فكأنه قال : إن دين الإسلام كفر • وهذا القول كفر من قائله ،

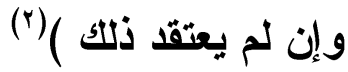

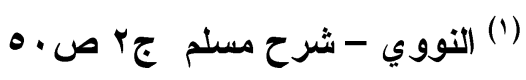

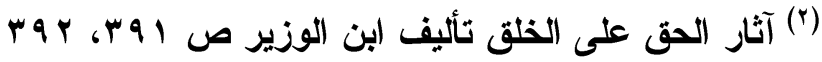


وقد أقلح ابن حزم في قوله :

" لا حجة لأحد في هذا الحديث ؛ لأن لفظه يقتضي أنه يأثث برميه

بالكفر ، ولم يقل عليه السلام : أنه بذلك كاقر "(1) وتعد قضية عدم التكفير في التأويل أروع ما قيل ومعروف أن كفر التصريح " واجب " فيما أجمعت الأمة على تكفيره ـ من هنا نتبين أهمية قول ابن الوزير :

" إن الجمهور لم يكفر المسلم متأولا في تكفيره غير متعمد ، مع أن الاحاديث الكثيرة تقتضي ذلك ، والنصوص أصح طرق التكفير - على فرض الأخذ بظاهر النصوص دون النظر إلى معارضتها - فان تورع الجمهور من تكفير من اقتضت النصوص كفره، فكيف لا يكون الورع أثذ من تكفير من لم يرد في كفره نص واحد ، فاعتبر الورع للجمهور

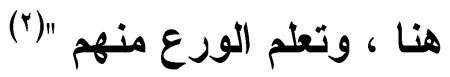

وتأمل هذه المواقف والكلمات للرسول وهذا التباين وهذا الثتاث في الفكر التكفيري ، ويؤكد تورعهم من التكفير مع ورود النصوص المتواترة الصريحة لوجوه نذكر منها :ا-علدم تكفير النبي الله عنه- لحاطب بن أبي بلتعة سرضي الله عنه- وكتكفير معاذ - رضي 


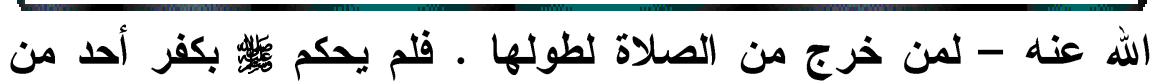

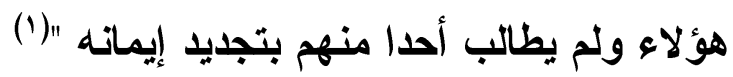

r-أباح الخوارج لأففهم الخروج على الإمام على - رضي الله عنه

- وبغضهم لله بل تكفيرهم إياه .

وحين نضع كل هذا في مواجهة الإمام على - رضي الله عنه -

فيطيهم حجمه الحقيقي حين سئل عن كفرهم " فقال الخوارج : من هن الكفر فروا ... فقيل أمنافقون هم؟ فقال: إن المنافقين لا يذكرون الله إلا عيل قليلا ، وهؤلاء يذكرون الله كثيرا ـ قيل فمن هم ؟ قال : هم إخوانتا بالأمس بغوا علينا ، فحاربناهم حتى يفيئوا إلى أمر الله ، وقد أقرته

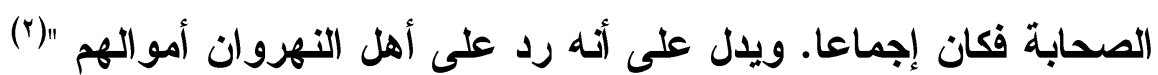
ولو كانوا كفارا ما رد عليهم أموالهم .

ونصل بقضية تكفير من لم يكفر الكافر إلى قلب المحور الذي نتغياه

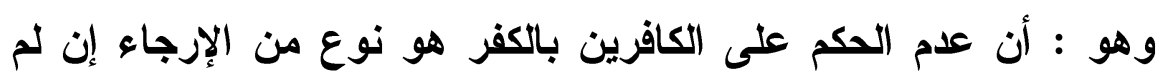
يكن من النفاق بل عدم تكفير من كفر بالله تعالى كفر شريطة أن يكون ورد في تكفيرهم نصوص شرعية قاطعة الثبوت والالالة كالمشركين ، والملحدين ، واليهود النصارى ، ومن في حكمه وهذا مما لم يختلف عليه أحد من المسلمين . ولن ولين

(1) أحكام عصاة المؤمنين المؤلف: مروان كجك صع ه الناشر: دار الكلمة الطبعـة

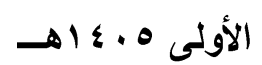

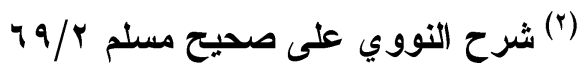


ويتبدى بوضوح أن من أجمعت الأمة على كفره ، أو ردته عن

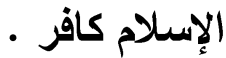

وبعد فلماذا لا نفهم من قضية التكفير أن :

التكفير هو : الحكم على من سبق له عقد الإسلام بالكفر .

وأن هذا الحكم يكتسح كل شيء في طريقه. الإيمان بالله تعالى وشريعته " جل وعلا ". ولهذا ورد النهى في كتاب الله تعالى وسنة نبيه

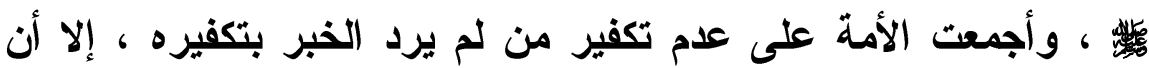

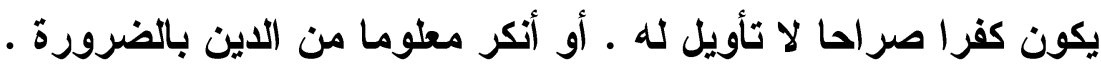
ألسنا مطالبين بقراوة النصوص الثرعية ؟!

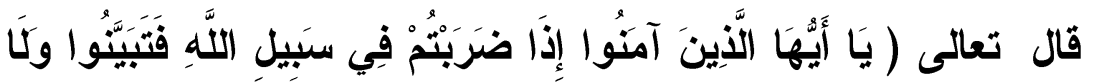

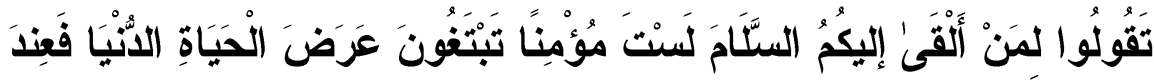

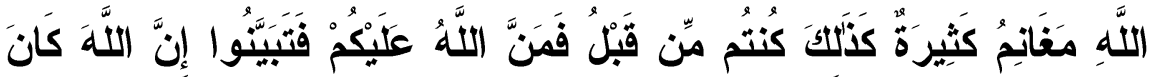

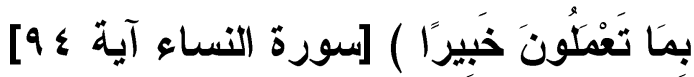

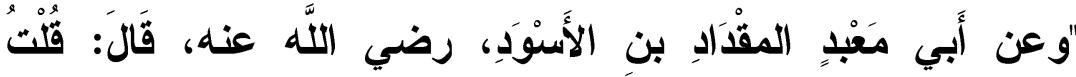

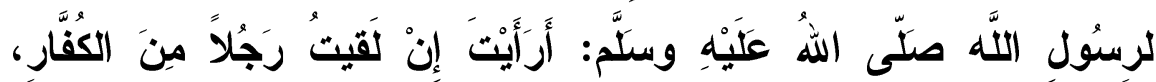

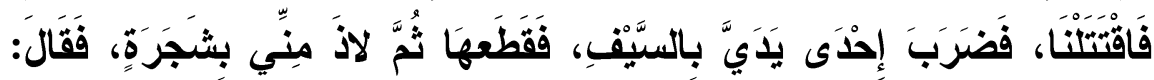

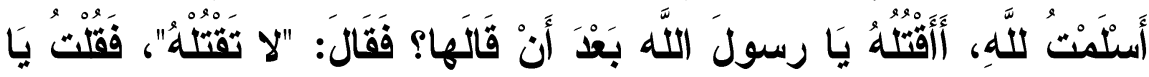

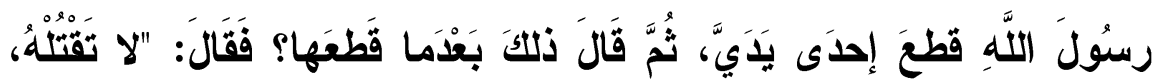




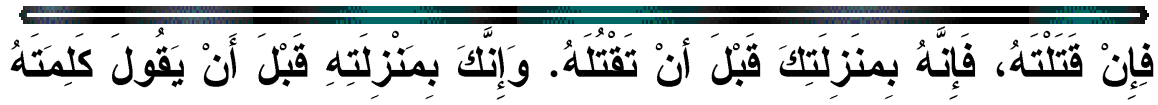

(التي قَالَ" (1)

ويتهلىَّ العلماء إلى رصد أسباب عدم تكفير جمهور العلماء لأحد من

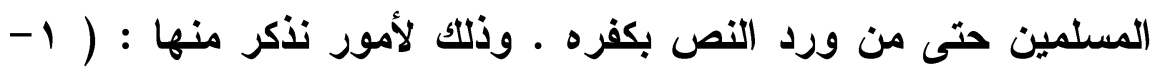
الرسول

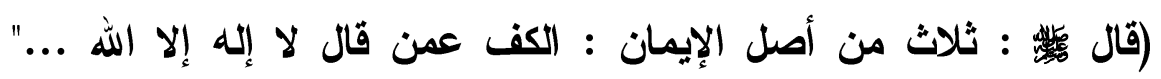
الحديث

وقال

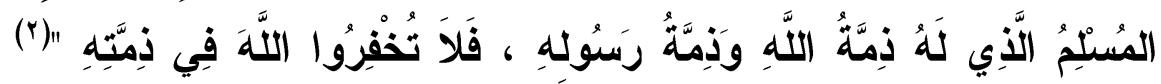
والمراد بأهل القبلة : من يصلي صلاة المسلمين " r - كذلك يمكن أن نلاحظ عدم حكم التبي

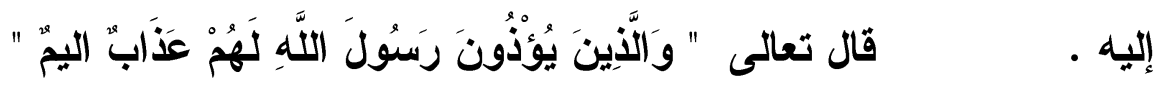

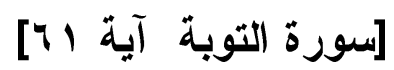

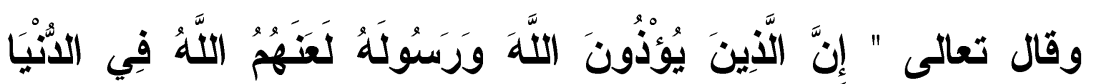

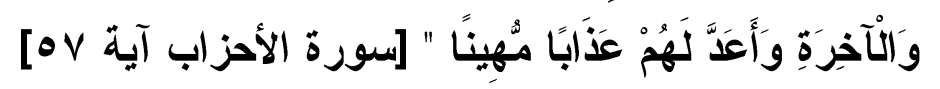

r-ويمكن النظر إلى عدم تكفير النبي

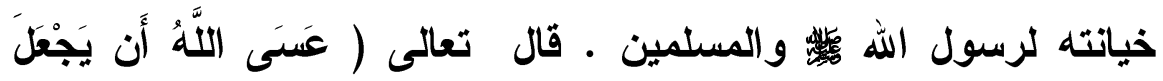

(1) أخرجه البخاري في "صحيحه" ( كتاب المغازي ، باب حدثي خليفـة) (ه / • (^) برقم: (19)

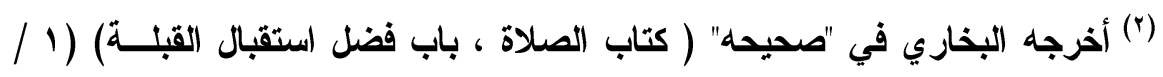

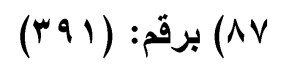




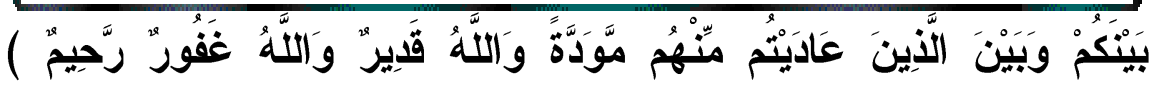

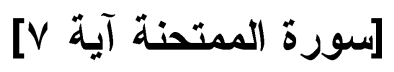

ع -ومن الحق أيضا أن يقال : إن عدم تكفير الإمام على للخوارج مع

خروجهم عليه وقتالهم له ـ وتكفير هم لعلى ولأصحاب رسول الله انعطافة هائلة حدت بالعلماء إلى عدم التكفير ـ فقد سئل الإمام على عن إنى

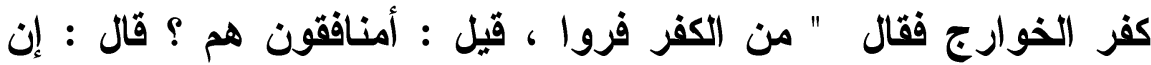

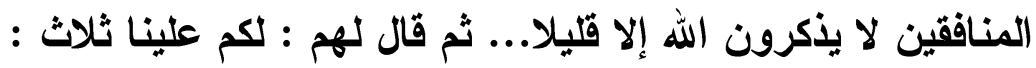
1-أن لا نبدأكم بقتال ـ r- وأن لا لا نمنعكم مساجد الله أن تذكروا

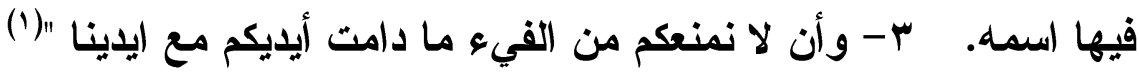
ه- ولنكن على وعى بالنصوص الثرعية التي تفيد العفو عن الخطأ ومن جملة هؤلاء المتأول فإته خاطئ ولا سبيل لنا بالقول بتعدده أضف إلى ذلك أن مراد المخالف قد يدق علينا فنفسره على غير مراده .

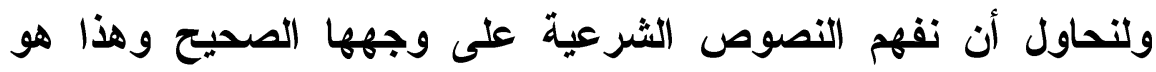

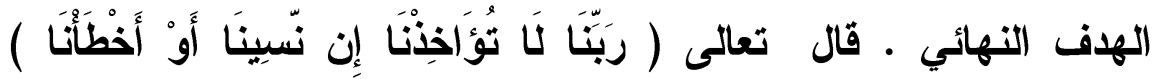

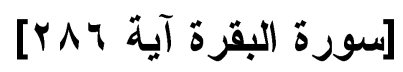

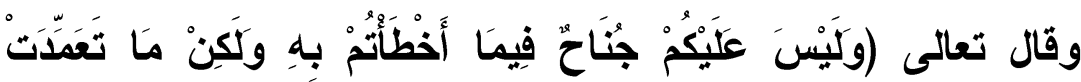

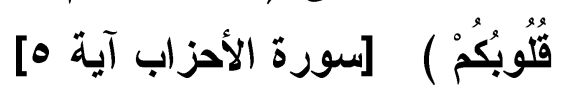

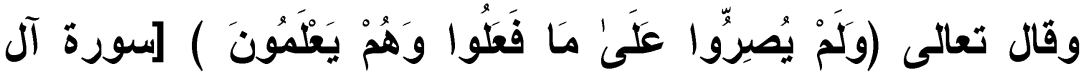

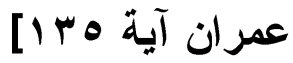

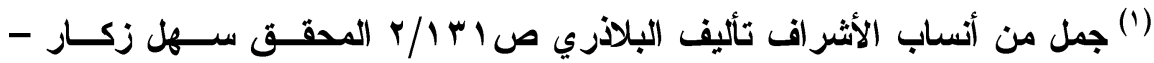
رياض زركلي سمصر في 10 ـام وانظر - إثار الحق على الخلق لابن الــوزير 


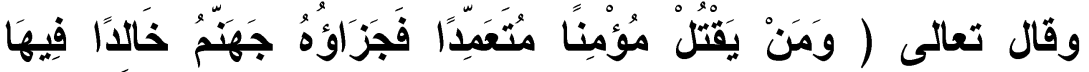

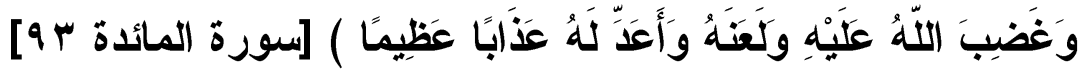

צ-و البارز في قضية التكفير أنها تحيل القضية ليس إلى مجرد روئية

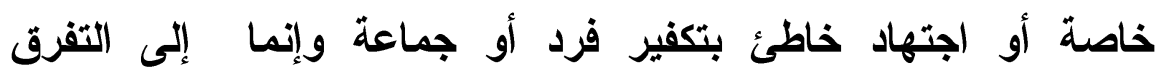

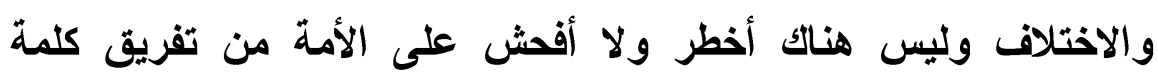

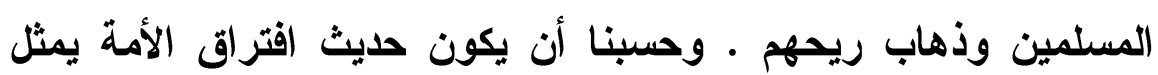

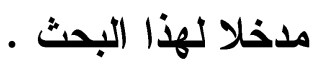




\section{المسألة الثالثة}

فيع قضية التكفير

مسائل يجب أن تفهم

ومفاهيم يجب أن توضه

وتثتتمل هذه المسألة علي ما يأتي :

$$
\begin{aligned}
& \text { ا - الحاكمية والتشريع } \\
& \text { r- الولاء والبراء } \\
& \text { r- الشورى في الإسلام } \\
& \text { ع- الدين النصيحة }
\end{aligned}
$$

ه- انمراف السلطة الحاكمة والخروج عليها 


\section{أولا : الحاكمية والتشريع}

يقفز العلماء إلى قضية الحاكمية والتشريع يوسعونها شرحا وتفصيلا

وتحليلا وتعليلا، ويعري الكثيرون منهم فكر الخوارج والثيعة لنرى ما خلفه هذا الفكر وذالك من أخطاء وأخطار . ويناشدونتا على الدوام أن نظل قريبين من نبع النصوص الشرعية

وفي البداية نحن أمام تعريف الحاكمية والولاية في اللغة

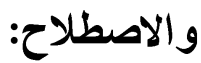

يقول صاحب لسان العرب ( حاكمية : ( اسم ) مصدر صناعي من

حاكم : منصب الحاكم أو وظيفته أو لقبه الوظيفي )(')

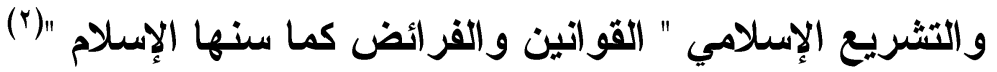

ونستطيع أن نقول : إن الحاكمية والإمارة ـ بمعنى واحد .

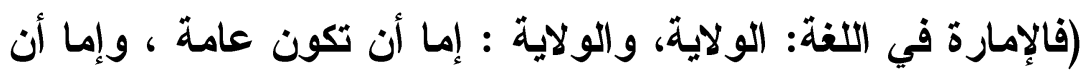

(ب) تكون خاصة)

ومن معاني الإمارة كذلك : الخلافة والحكم (؛) ويطلق على من يأخذ منصب الإمارة . أمير ، والجمع أمراء ... ويندرج فيهم الخلفاء والسلاطين و الولاة والقضاة وغيرهم •

(1) لسان العرب تأليف ابن منظور ص99 11 مادة حكم، طبعـة دار صــادر بيـروت

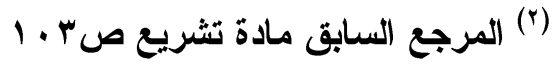

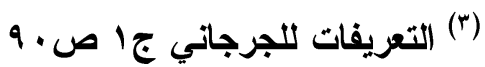

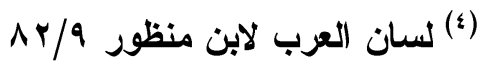




$$
\text { الإمارة في الشرع : - الشر }
$$

عرفها الماوردي بأنها:- موضوعة لخلافة النبوة في حراسة الدين،

وسياسة الانيا به(1)

وعرفها الجويني فقال : الإمامة رياسة تامة ، وزعامة عامة ، تتعلق

بالخاصة والعامة في مهمات الاين والانيا متضمنها "حفظ الحوزة"(؟) ورعاية الرعية ، واقامة الدعوة بالحجة والسيف ، " وكف الحنف "() " والحيف "(؛) والاتتصاف للمظلومين من الظالمين ، واستيفاء الحقوق من الممتنعين، وايفاؤها على المستحقين(•)

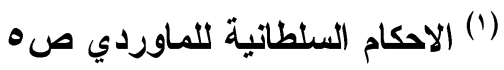

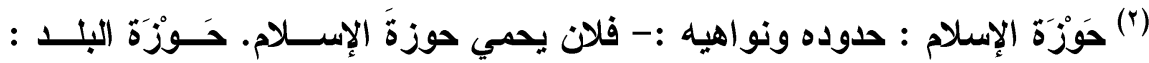

$$
\text { أنظر معجم: اللفة العربية المعاصر في حوزه : بملكه ، أو عنده. }
$$

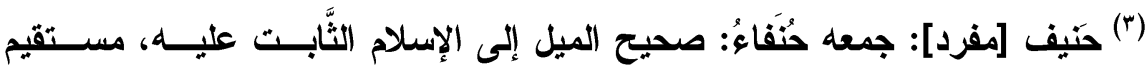

$$
\text { منصرف عن الضَّلال متَّجه إلى الحقِّّ }
$$

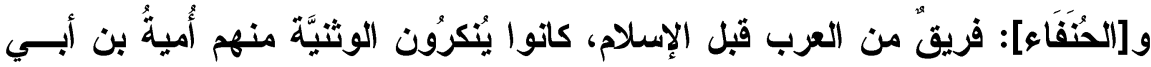

$$
\text { الصَّت }
$$

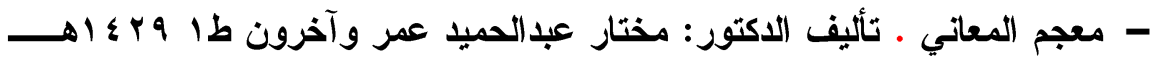

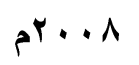

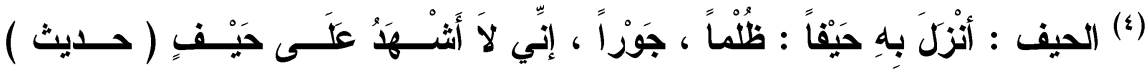

$$
\text { المرجع السابق الأق }
$$

(0) غياث الأمم في التياث الظلم صهـهـ تأليف : الجويني - عبد المثلك بن عبدالله بن

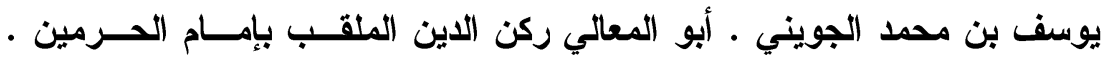

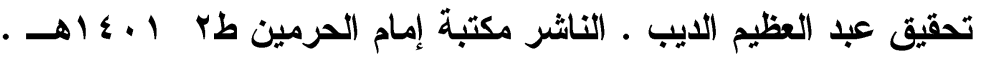


وإذا كاتت الإمارة خاصة، فهي الولاية على الغير، والقيام بها بما

$$
\text { فيه تحقيق المصالح (1) }
$$

ونتوجه إلى قضية الحاكمية في الأحاديث النبوية :

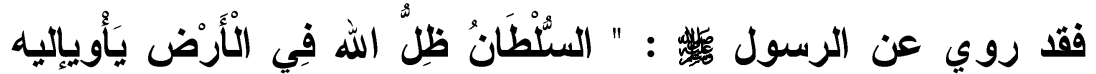

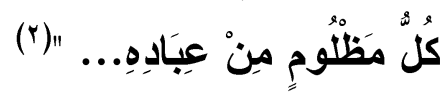

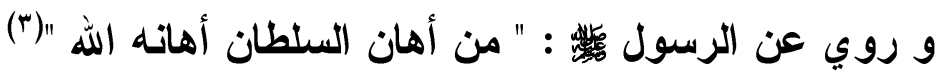

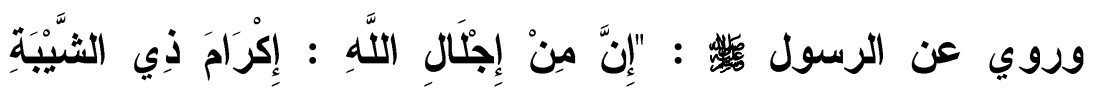

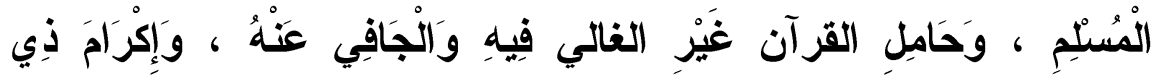

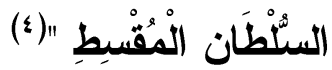

و إلى جاتب ما امتاز به الحاكم العادل من تشريف الله له - ظل الله - كبيت الله، وناقة الله ... الخ ولكنتا لا نستطيع تجاوز هذا المأخذ الأي لحظه القدماء والمحثثن وبخاصة على تفسير الثيعة والخوارج لنإمامة.

فإذا كان ( الخوارج أول من أطلق هذه الكلمة " لا حكم إلا لله " أو "

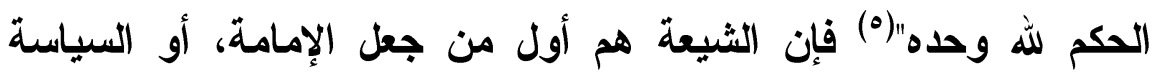
أصلا من أصول الاين، وجعلوها وظيفة دينية ، وقالوا : إنها ركن الدين

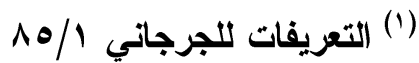

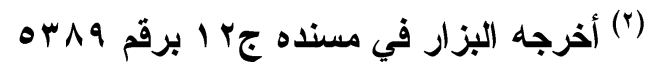

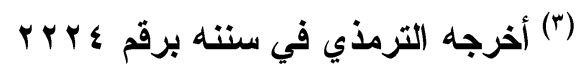

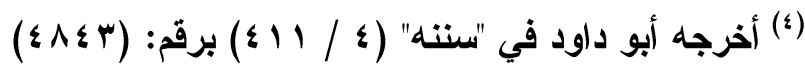

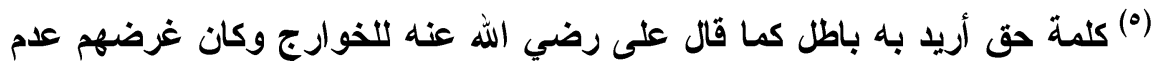

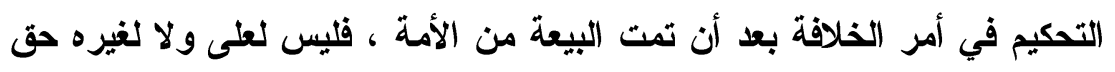
التحكيم بعد ذللك. 
وأساسه ، وأنها نص ووصية ، وليست مصلحة اجتماعية يفوض الأمر

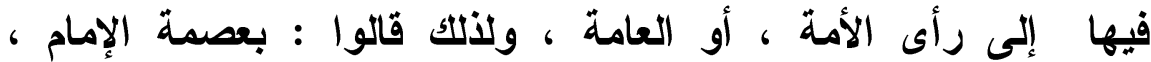

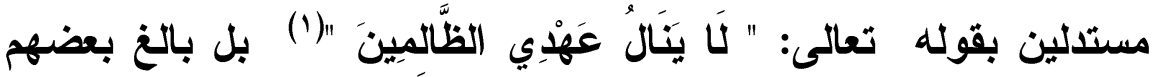
إلى القول والاعتقاد بقداسة الأثمة .

لقد جنح الفكر الثيعي وفكر الذوارج إلى الحجاج والمجادلة بالباطل • يقول العلامة ابن خلدون " وشبهة الثيعة الإمامية في ذلك : إنما هي كون الإمامة من أركان الاين كما يزعمون ، وليس كذلك ، وإنما

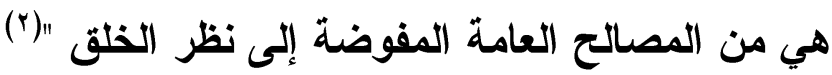
وشبهة الثيعة أوضح من أن تكون موضعا لجدال فالإسلام لا يقول بالسلطة الاينية كما تقول الثيعة ولا يجعل الحكم لفرد بعينه ؛ لأن نظام الحكم في الإسلام شورى بين المسلمين ، ولهذا جاعت آيات القرآن الكريم ، وتوجيهاته ، وأحكامه ، وأوامره ، ونواهيه، جميعا إلى الأمة لئل

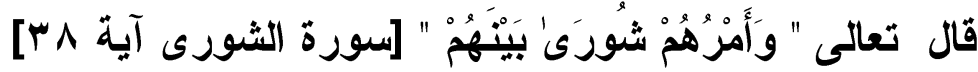
فالثارع الحكيم وضح للمسلمين قواعد كلية في آيتين من آيات القرآن الكريم يجب على الحاكم والمحكوم رعايتها وتطبيقها تحقيقا

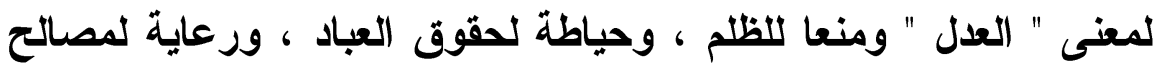

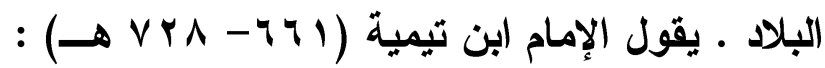

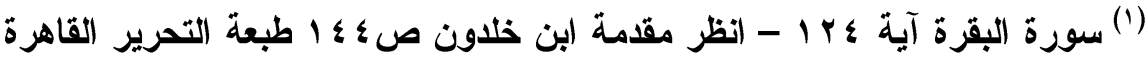

$$
\text { م) }
$$

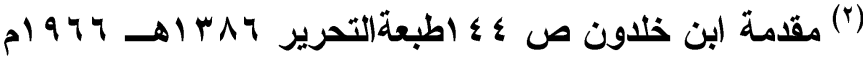


" ومرجع السياسة الشرعية في الإسلام إلى " آية واحدة "(1) طلبث من الأمراء أداء الأمانات والحكم بالعدل ، وآية أخرى "(r) طلبت من

الرعية الطاعة لأولى الأمر إذا هم أدوا الأمانات وحكموا بالعدل "(r) وتعد كلمات الإمام ابن قيم الجوزية (19 أروع ما قيل في السياسة العادلة أو الشريعة الكاملة من فكر . يقول الإمام " إن الله - تعالى - أرسل رسله ، وأنزل كتبه ليقوم الناس بالقسط ، فإذا ظهرت أمارات الحق ، وقامت أدلة العدل ، بأي طريق فثم شرع الله ودينه ورضاه وأمره ، والله تعالى لم يحصر طرق العدل وأدلته وأمار اته في نوع واحد وأبطل غيره من الطرق.... فأي طريق استخرج به الحق ، ومعرفة العدل ، وجب الحكم بموجبها ومقتضاها، والطرق أساليب ووسائل لا ثراد لأواتها ، وإنما المراد غايتها التي هي المقاصد.... ولا نقول إن السياسة العادلة مخالفة للشريعة الكاملة ، بل

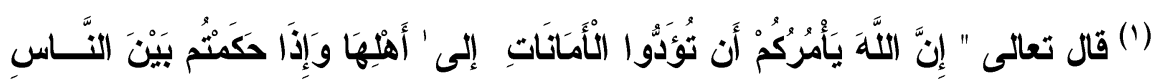

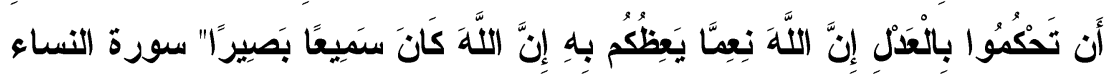
آية آن آنمان

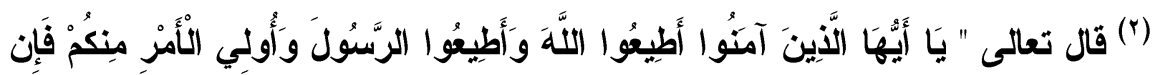

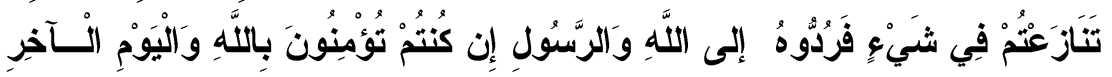

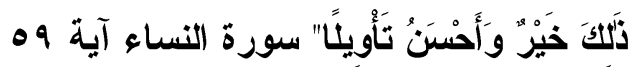

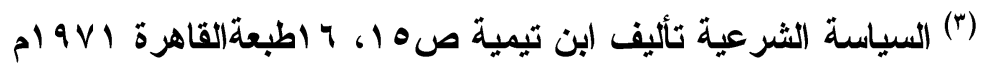


هي جزء من أجزائها ، وباب من أبوابها ، وتسميتها سياسة أمر

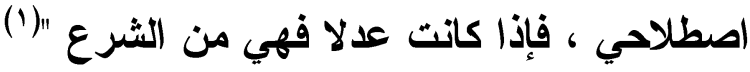

ويبدو موقف ابن القيم من السياسة العادلة أوضح من أن يعرف به

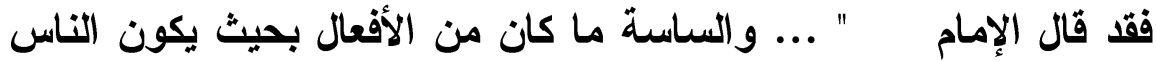

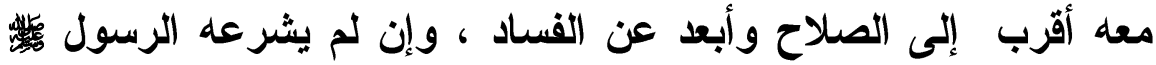

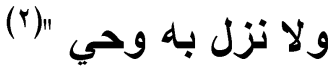

فإذا تجاوزنا فكر علماء الإسلام في قضية السياسة العادلة ، وهو

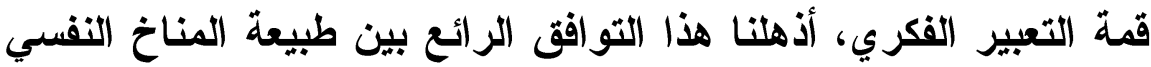
لخليفة رسول الله بوحها في قوله " لمن دعاه بخليفة الله ، قال- الصديق - لست خليفة

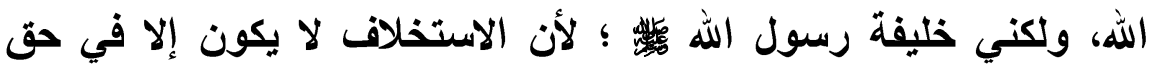

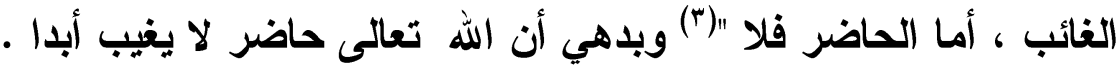
ولقد فطن الخليفة الأول أبو بكر الصديق لحقيقة استخلافه حين قال

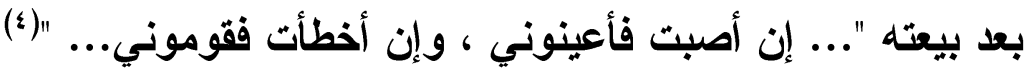

(") إعلام الموقعين عن رب العالمين ـ تأليف "ابن القيم" - محمد بن أبي بكـر بـن بـن

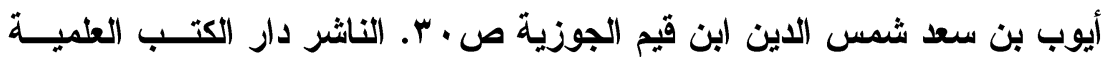

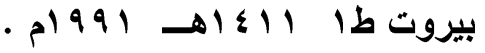

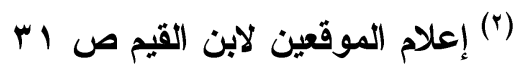

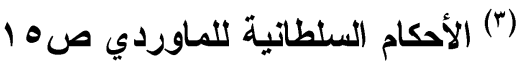

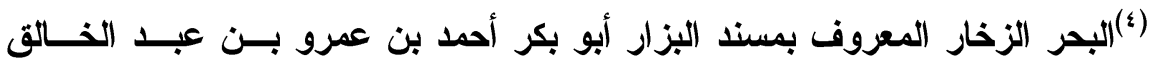

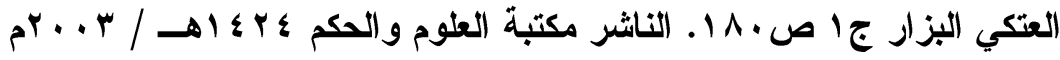


كذلك يمكن أن نلاحظ : أن قول " الحاكمية لله " إذا كان المراد بها أنه تعالى واضع أساس الحكم والمحاسب على تنفيذه والآمر به فلا

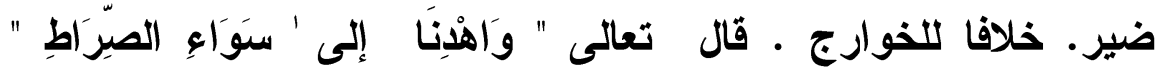

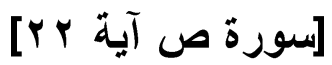

ونستطيع - في مجال - تحديد معنى الحكم في القرآن الكريم أن نقول : جاء الحكم بمعنى الحكمة والإصابة في القول أو العمل ، وبمعنى القضاء والقدر ، وبمعنى المالك للأمر كله ، وبمعنى القضاء بين الناس في الآخرة ، وبمعنى ... الخ ولغ ولغ

وبوسعنا أن نرجع إلى الآيات القرآنية الكريمة لنرى المعاني

المتعددة للحكم في الإسلام :

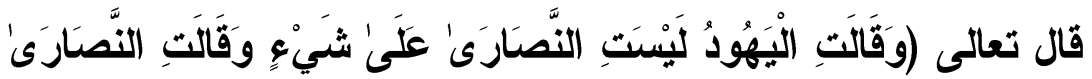

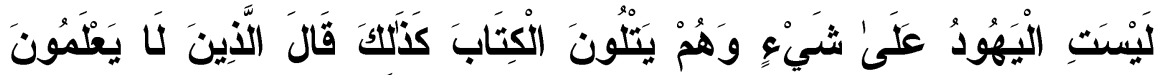

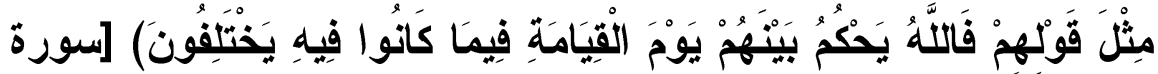

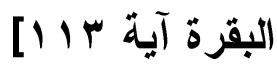

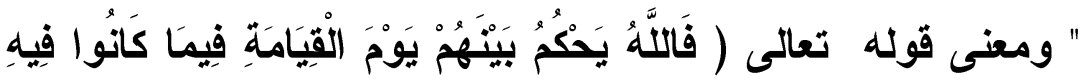

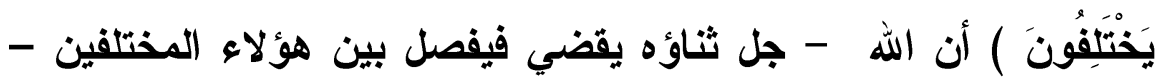
القائل بعضهم لبعض : لستم على شيء من دينكم - يوم قيام الخلق

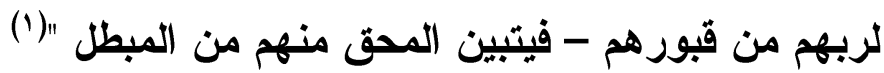

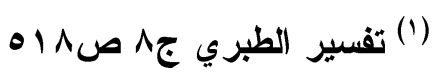




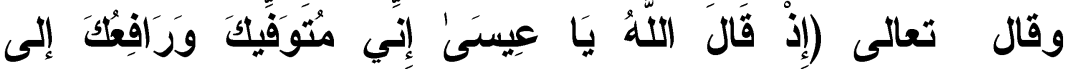

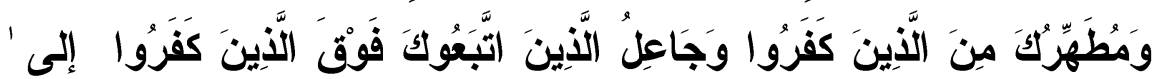

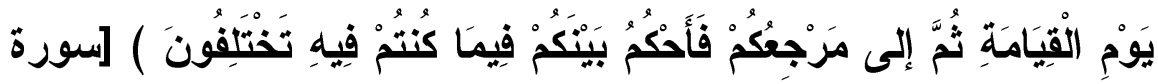

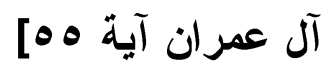

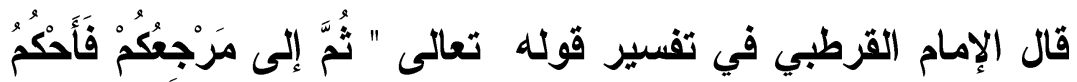

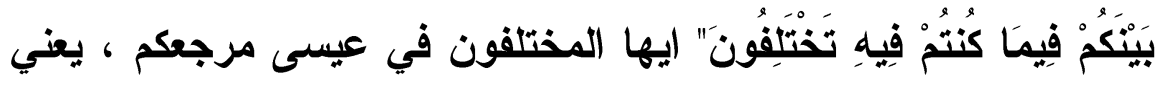

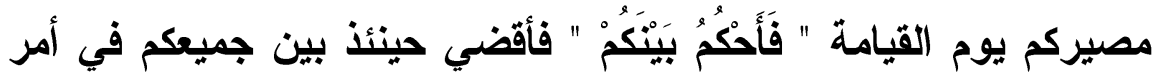

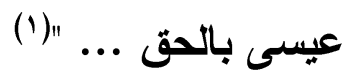

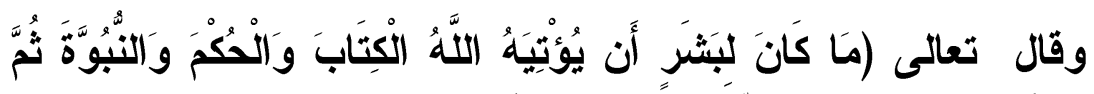

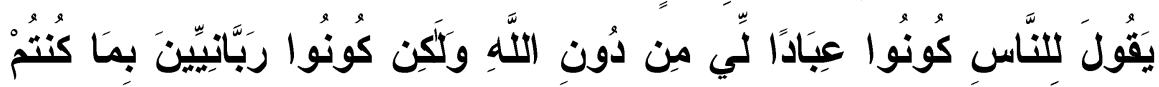

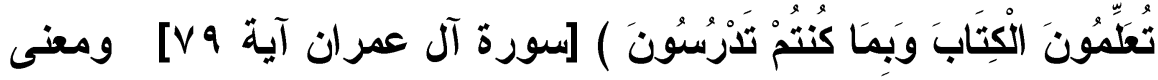

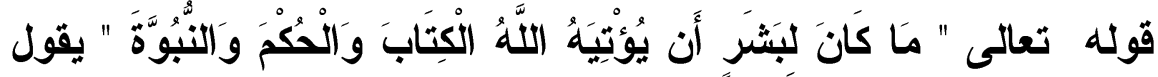
ابن كثير: "ينزل الله عليه كتابه والحكم يعني ويعلمه فصل الحكمة ...

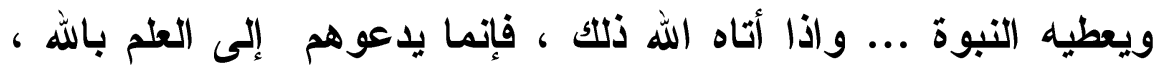

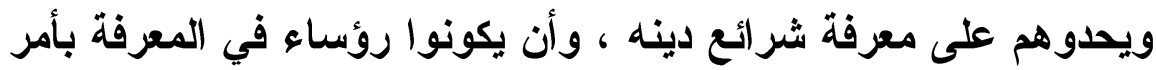
الله ونهيه ، وأئمة في طاعته وعبادته ، بكونهم معلمي الناس الكتاب ،

وبكونهم دارسيه "(†)

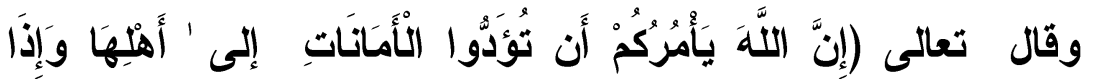

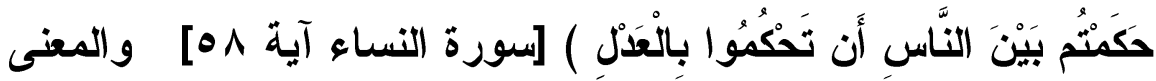

$$
\begin{aligned}
& \text { (1) تفسير القرطبيجه ص ص. 1. }
\end{aligned}
$$

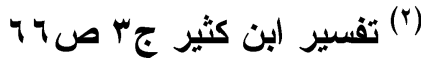


" أن الله يأمركم ، يا معشر ولاة أمور المسلمين ، أن تؤدوا ما ائتمنتكم عليه رعيتكم من فيئهم وحقوقهم وأموالهم وصدقاتهم إليهم ، على ما

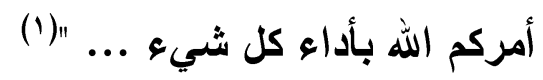

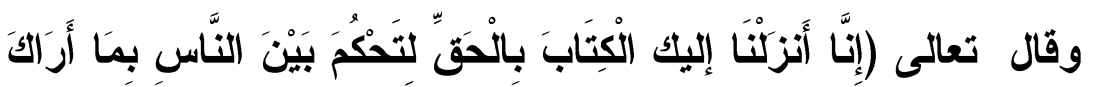

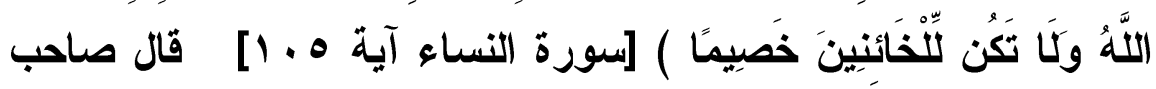
الجلالين " أي هو حق من الله القرآن الكريم - وهو يتضمن

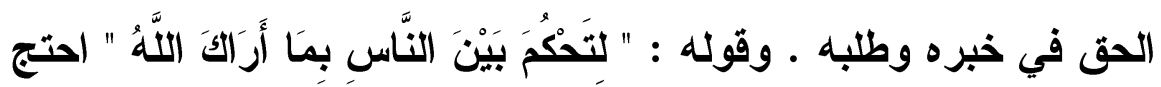
به من ذهب من علماء الأصول الى أنه كان ، عليه السلام ، له أن يحكم

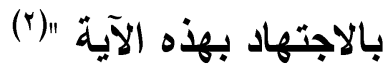

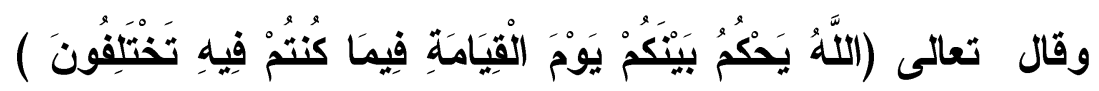
[سورة الحج آية 9 7] ومعنى الآية الكريمة " اي بما يعلمه منكم يأيها المناققون من البواطن الرديئة ، فلا تغتروا بجريان الأحكام الثرعية عليكم ظاهرا في الحياة الانيا ، لما له - تعالى - في ذلتك من الحكمة .

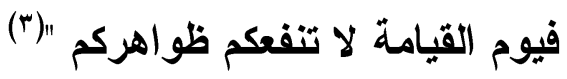

$$
\begin{aligned}
& \text { (') تفسير البغوي جr صمبr (1) }
\end{aligned}
$$

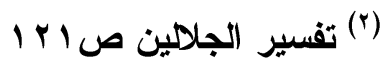

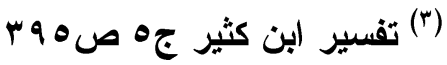


وقال تعالى (إِنَّ اللَّهَ يَحْكُمُ مَا يُريدُ ) [سورة المائدة آية 1)] والمعنى " أن علة حسن التكليف هي الربوبية والعبودية لا ما يقوله المعتزلة من

رعاية المصالح "(1)

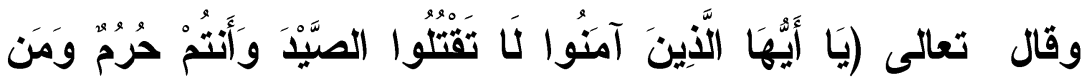

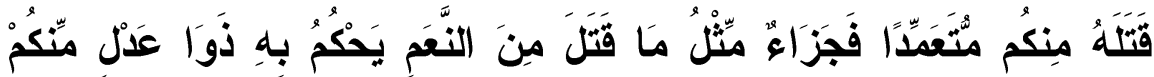

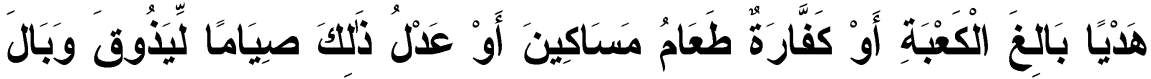

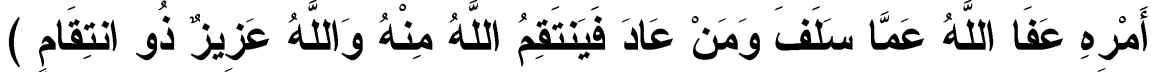

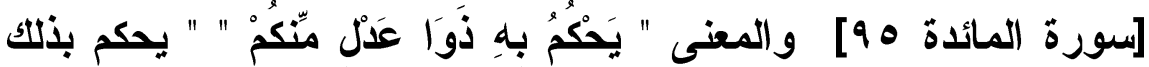
الجزاء الأي هو مثل المقتول من الصيد من النعم عدلان منكم، يعنى :

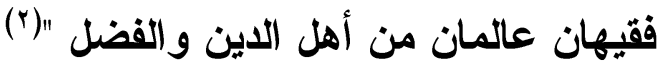

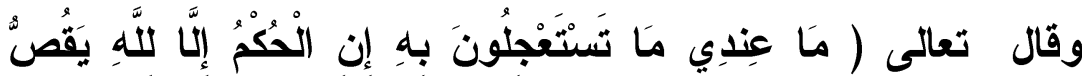

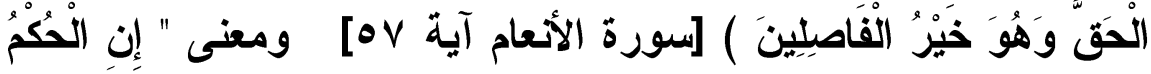
إلَّاّ للَّهِ " " الحكم الفاصل بين الحق والباطل لله ... ويجوز أن يكون

المعنى : يقضي القضاء الحق "(r)

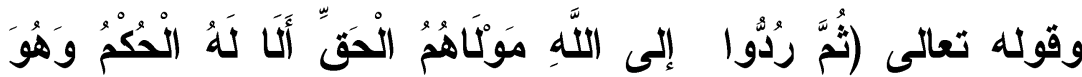

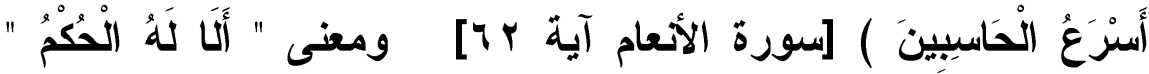

(1) مفاتيح الغيب أو التفسير الكبير ـ تأليف "فخر الدين الرازي" - أبو عبد الله محد

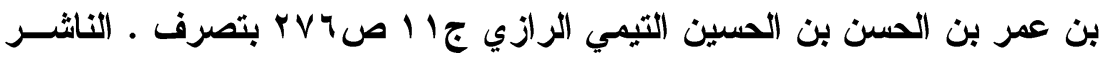

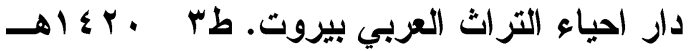

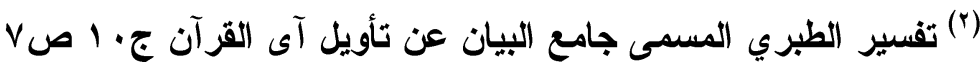

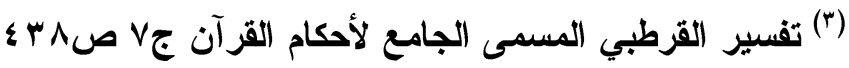


"وحده لا شريك له " وهو اسرع الحاسبين لكمال علمه وحفظه لأعمالهم

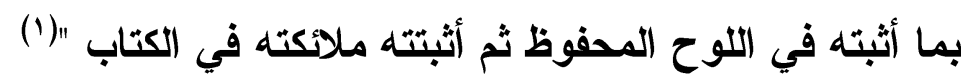

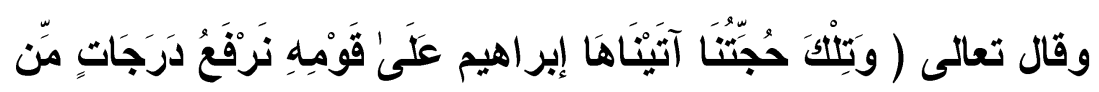

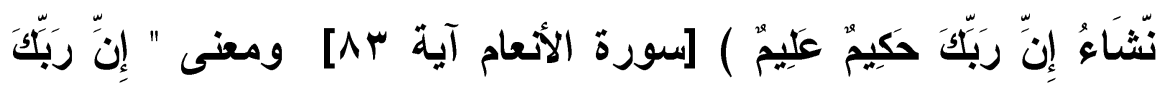

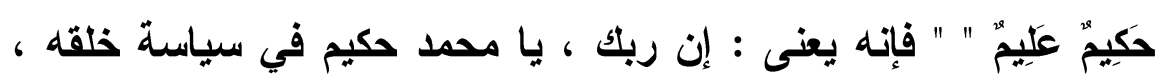

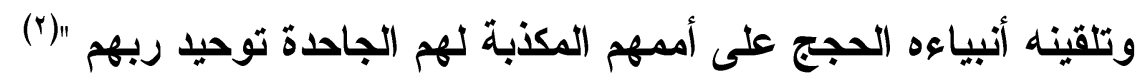

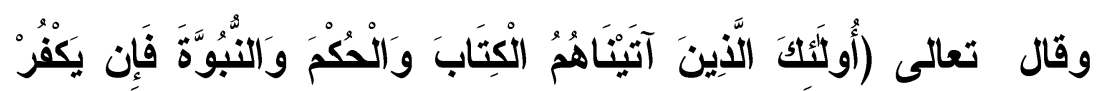

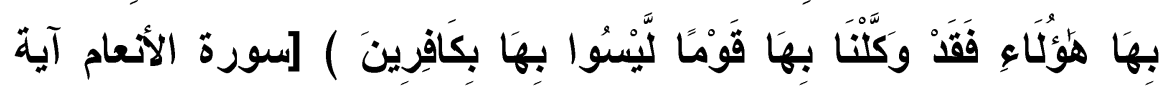

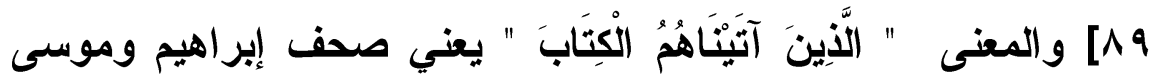
وزبور داود وإنجيل عيسى... " والحكم " الفهم بالكتاب ومعرفة ما فيه

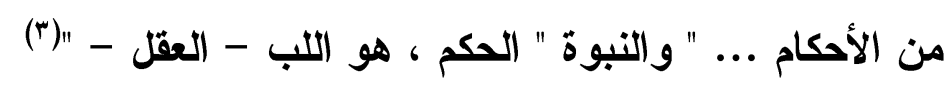

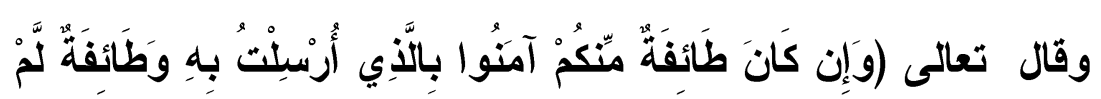

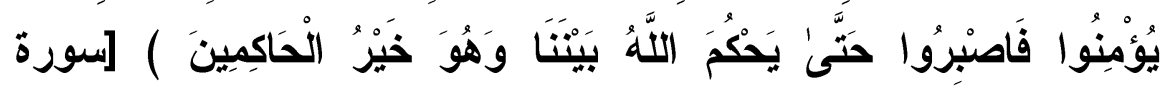

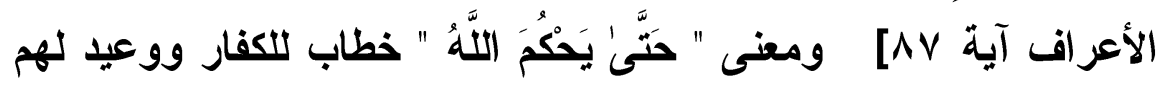
اي تربصوا لتروا حكم الله تعالى بينتا وبينكم فإنه سبحانه سينصر المحق على المبطل ويظهره عليه ، أو هو خطاب للمؤمنين وموعظة لهم

(1) تفسير السعدي المسمى تيسير الكريم الرحمن في تفسير كلام المنان صوهن (1)

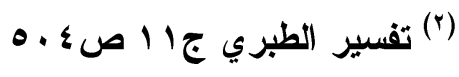

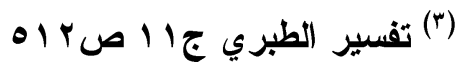


وحث على الصبر واحتمال الأذى ... " وَهُوَ خَيْرُ الْحَاكِمِينَ " إذا لا معقب

$$
\text { لدكمه ولا حيف فيه فهو في غاية السداد"(1) }
$$

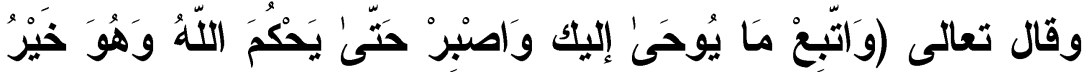
الحَاكِمِينَ ) [سورة يونس آية 9. 1.9] والمعنى " يا محمد وحي الله الأي ينزله عليك فاعمل به ، واصبر على ما أصابك من مشركي

قوملك... " وَهُوَ خَيْرُ الْحَكِمِينَ " وهو خير القاضين وأعدل الفاصلين "(؟)

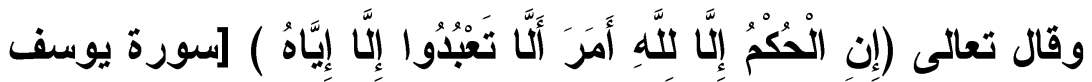

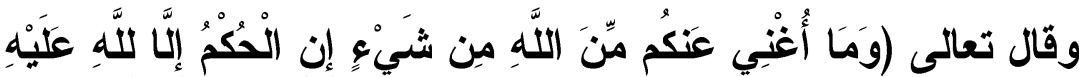

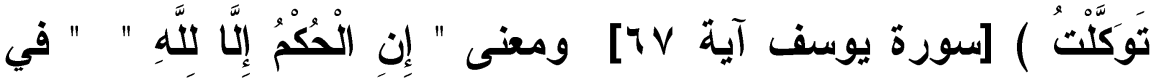

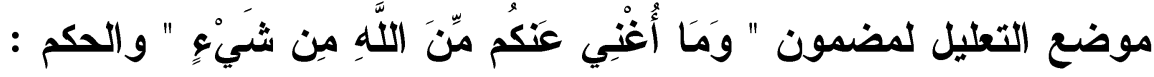
هنا بمعنى التصرف والتقدير ... لأنه لا يتم إلا ما أراده الله ... وليس ميس للعبد أن ينازع مراد الله في نفس الأمر ولكن واجبه أن يتطلب الأمور من أسبابها لأن الله أمر بذلك "(r)

(1) روح المعاني في تفسير القرآن العظيم والعـبع المثـــي تــأليف الألوســي ج؛

$$
\text { ص. }
$$

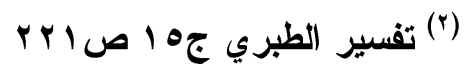

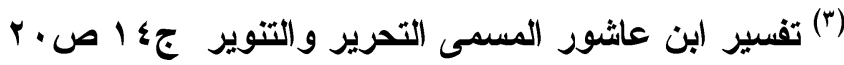




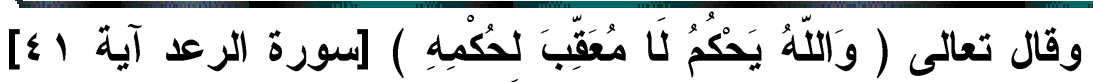

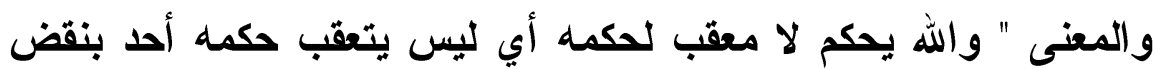

ولا تغيير" (1)

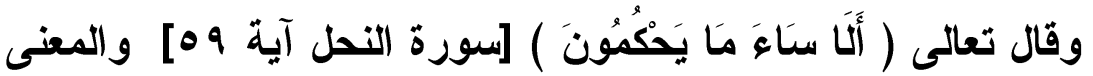

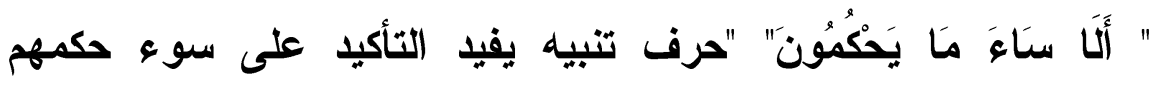

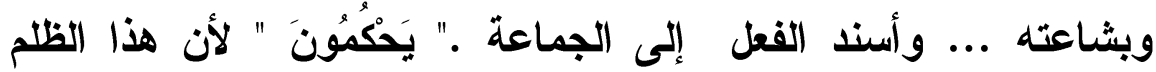

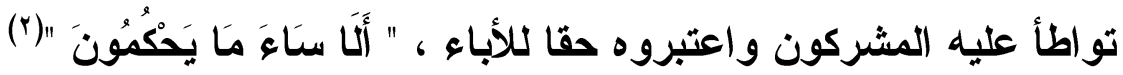

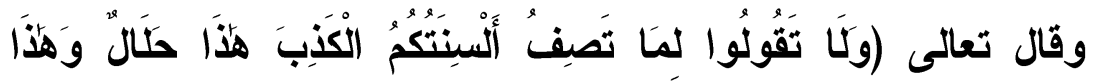

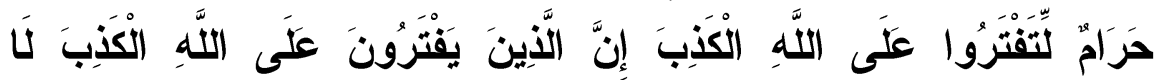

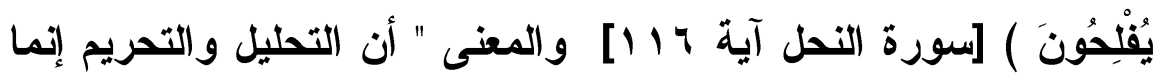

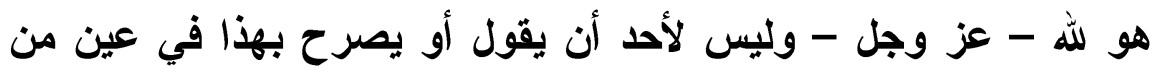

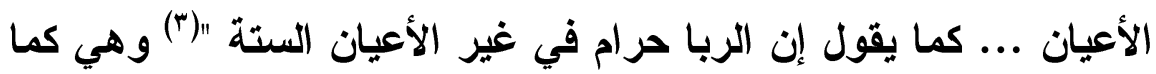
قال النبي

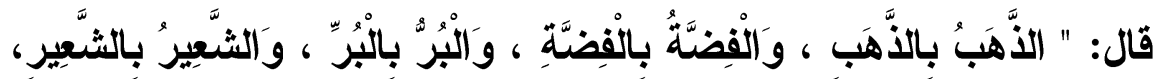

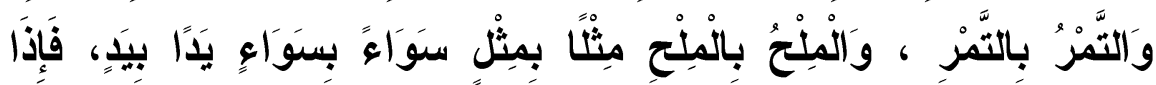

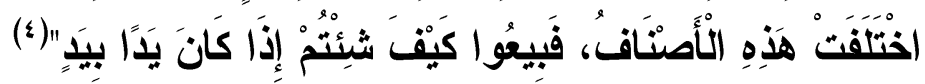

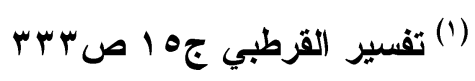

(") التفسير البياني لما في سورة النحل من دقائق المعساني تـأليف بنــت الثــاطئ

$$
\text { صaير }
$$

(")

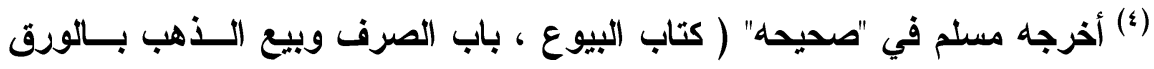

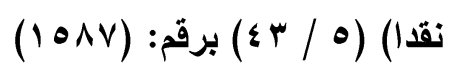




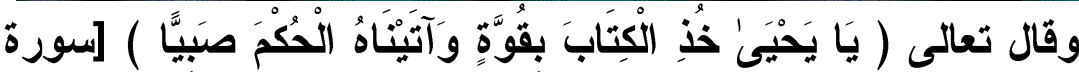

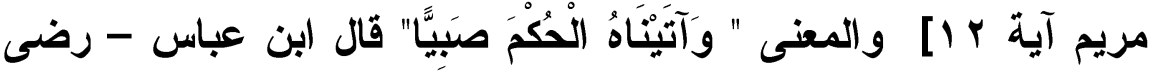
الله عنه - النبوة صبيا وهو ابن ثلاث سنين ـ وقيل : أراد بالحكم فهم الكتاب فقرأ التوراة وهو صغير • وعن بعض السلف : من قرأ القرآن

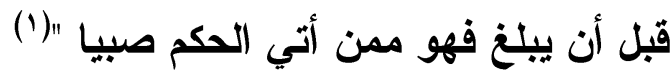

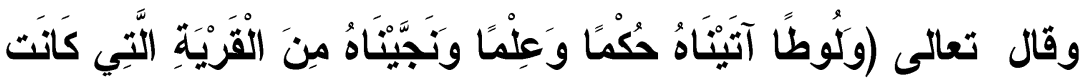

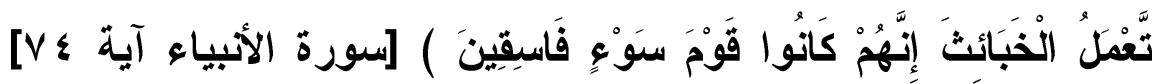

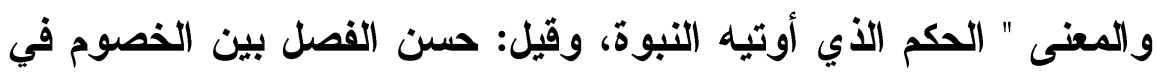
القضاء ، وقيل : حفظ صحف إبراهيم ... ولما ذكر الحكم ذكر ما يكون

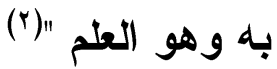

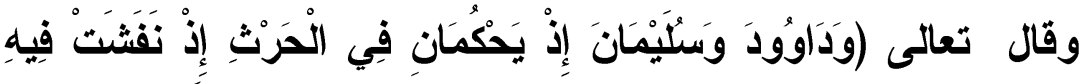

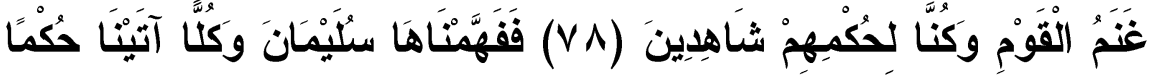

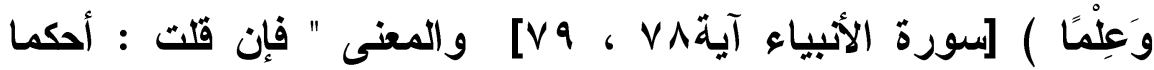

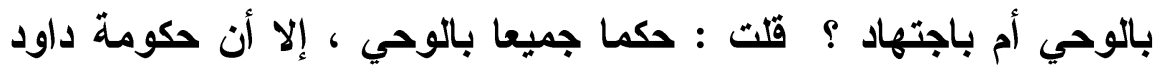
نسخت بحكومة سليمان- عليهما العلام - ، وقيل اجتها جميعا ، فجاء اجتهاد سليمان - عليه السلام- أثبه بالصواب ـ فإن قلت : ما وجها كل واحدة من الحكومتين ؟ قلت : أما وجه حكومة داود - عليه السلام -

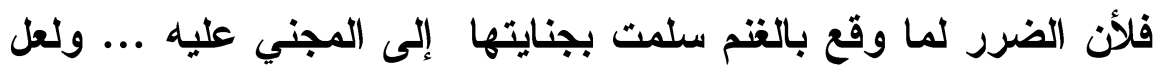
قيمة الغنم كاتت على قدر النقصان في الحرث ـ ينتفعون بألبانها وأولادها

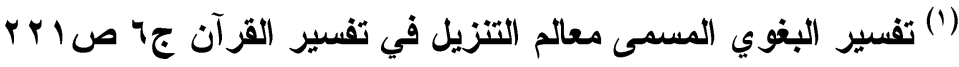

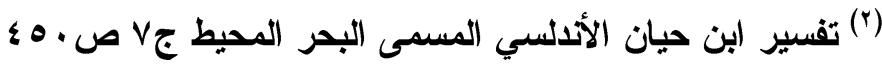


وأصوافها ، والحرث إلى أرباب الثاة يقومون عليه حتى يعود كهيئه

يوم أفسد "(1)

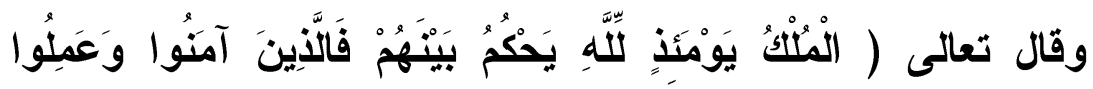

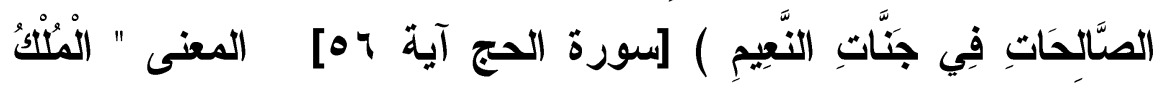

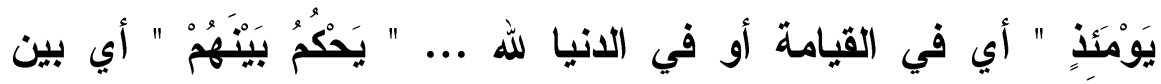
المؤمنين والكافرين بالأمر الفيصل ، لا حكم فيه ظاهر ا ولا باطنا لغيره...

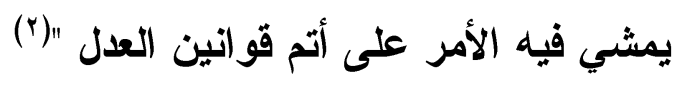

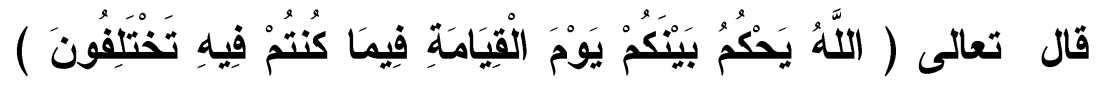
[سورة الحج آية 9 7] المعنى " ولهذا أمر الله تعالى بالعدول عن

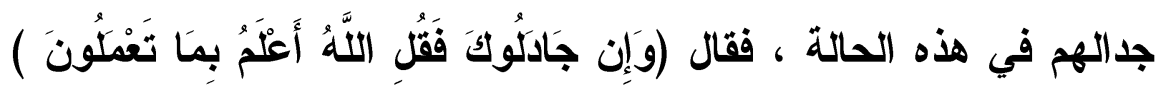

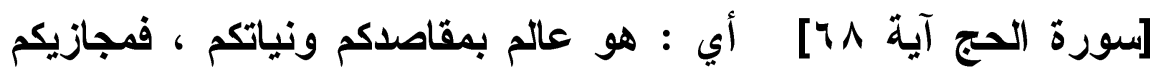
عليها في يوم القيامة الأي يحكم الله بينكم فيما كنتم فيه تختلفون ، فمن وافق الصراط المستقيم ، فهو من أهل النعيم ومن زاغ ، فهو من أهل

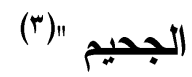

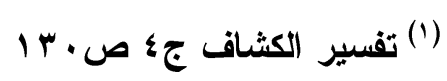

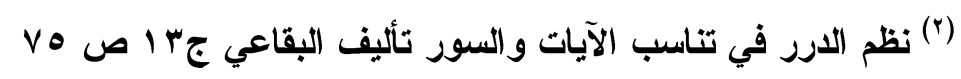

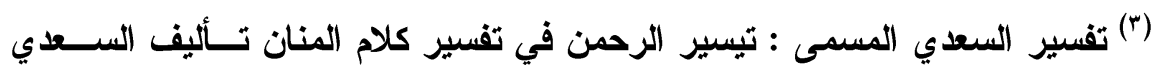
ص ص ص D 


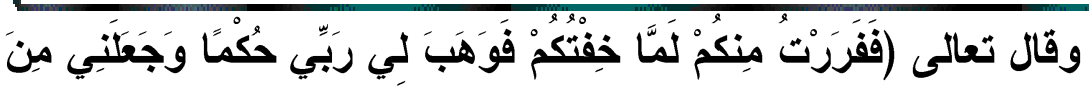

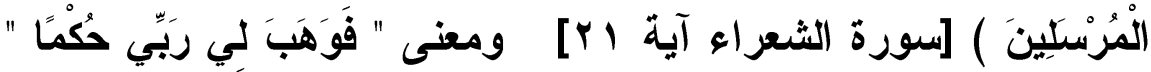

يعنى النبوة وقال مقاتل : يعني العلم والفهم "(1)

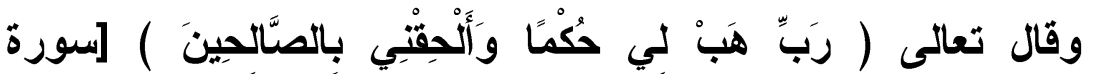

الشعراء آية بr/] المعنى " من أراد أن يشتغل بالاعاء يجب عليه ثناء الله تعالى وذكر عظمته وكبريائه... ثم لم يقتصر إبراهيم - عليه السلام - على الثناء ، لا سيما وروى عنه أيضا أنه قال: حسبي من سؤالي علمه بأحلى ، فالجواب : أنه عليه السلام إنما ذكر ذلك حين كان مشتغلا بلدعوة الخلق إلى الحق ... ولأن الثارع لا بل له من تعليم الشرع فأما حين ما خلا بنفسه... كان يقتصر على قوله " حسبي من سؤالي علمه

بحلى "r) بمن (r)

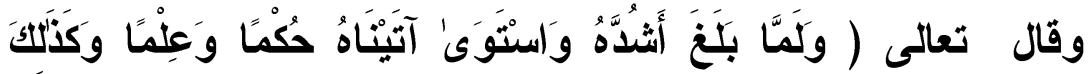

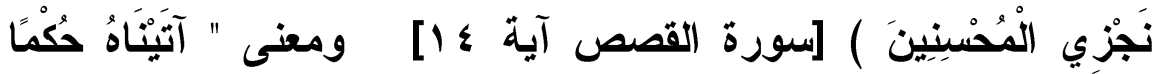
وَعِلْمًا " وقد قيل في المر اد بالحكم أربعة أمور: 1-إنه العقل ، قاله عكرمة . r-النبوة ، قاله السدى أو علما على ما هو من خواص النبوة على

ما تأول به بعضهم كلامهه . ب-القوة ، قاله مجاهد . ع -الفقه ، قاله ابن اسحاق • 
ويحتمل أن يراد به علم الحكماء وأخلاقهم ـ وذكر الزمخثري أن

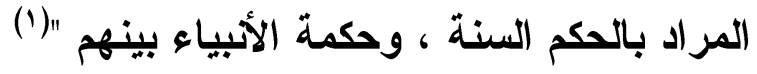

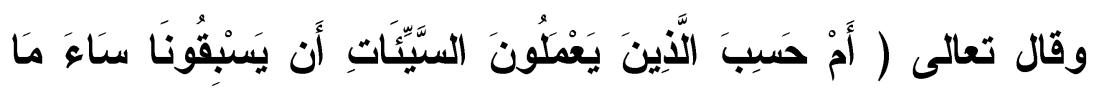

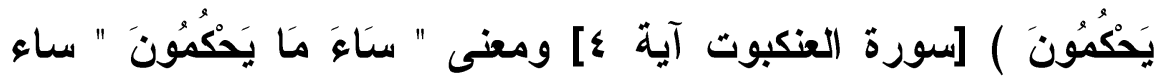
حكهم الأي يحكمون بأن هؤلاء الذين يعملون السيئات يسبقونتا

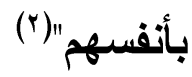

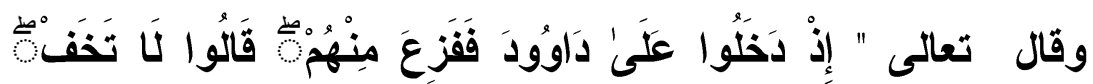

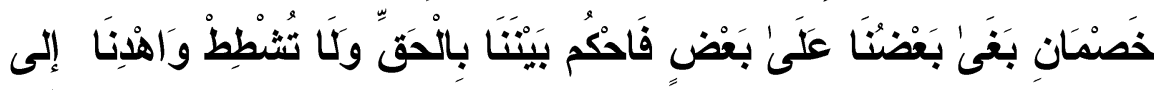

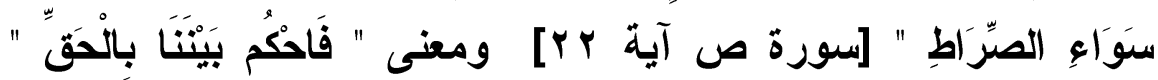

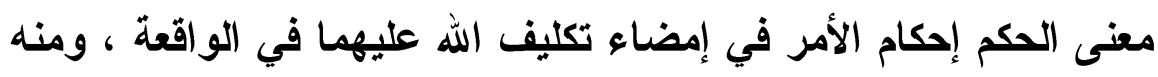

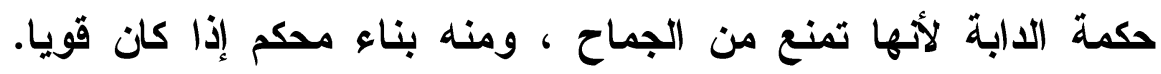

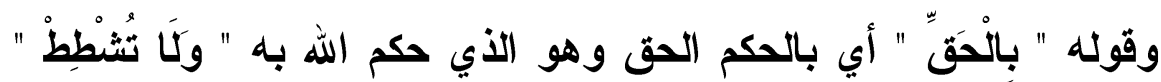

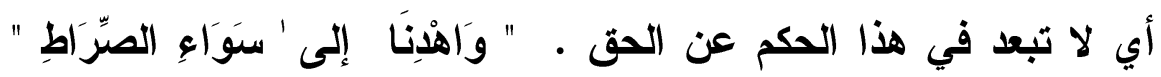
وسواء الصراط هو وسطه ووسط الثيء أفضله ـ ـوأقول إنهم عبروا عن المقصود الواحد بثلاث عبارات :

(1) تفسير سورة القصص دراسة تحليلية تأليف د. محمد المطغى صه صا 11 الناشر

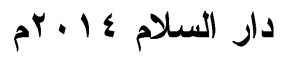

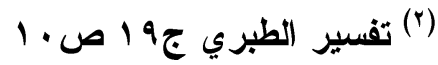




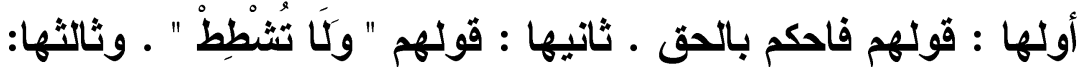

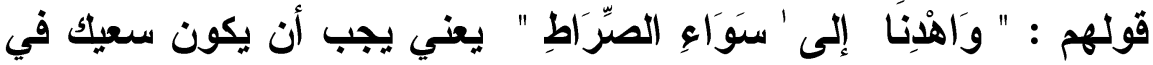

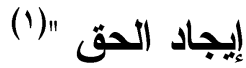

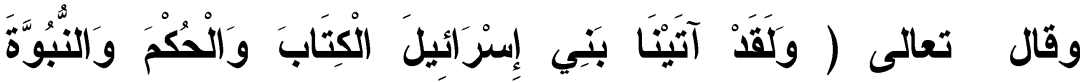

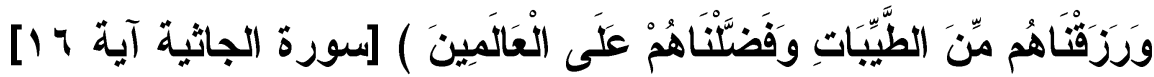

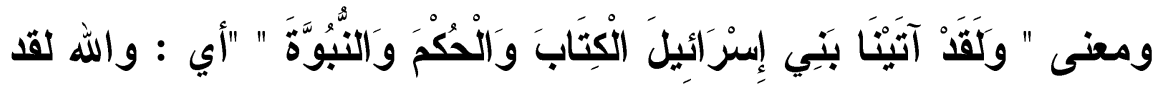
أعطينا بني اسرائيل الكتاب ليكون هلاية لهم ، وآتيناهم - أيضا - الحكم

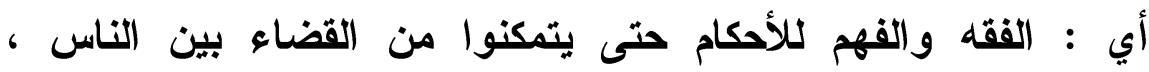

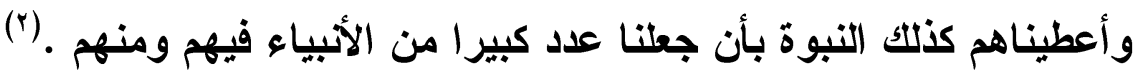

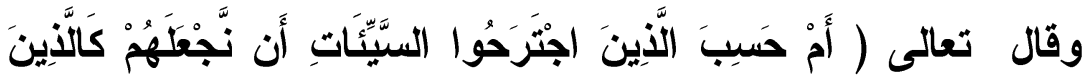

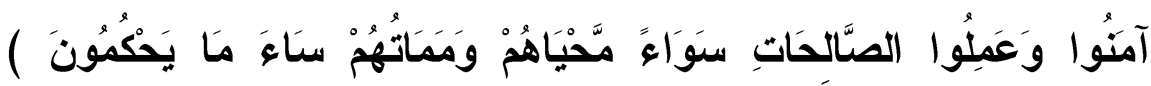

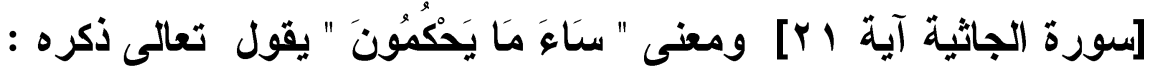
بئس الحكم الذي حسبوا أنا نجعل الذين اجترحوا السيئات والذين آمنوا

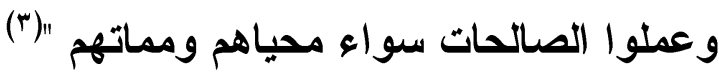

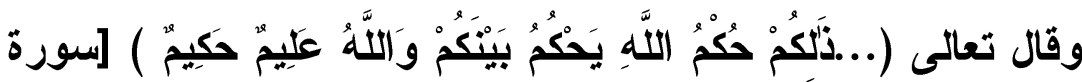

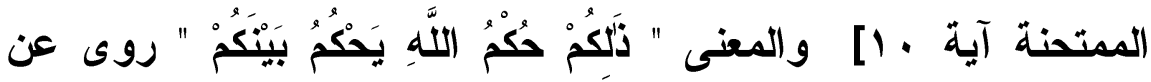
الزهري ومسروق أن من حكم الله تعالى أن يسأل المسلمون من الكفار

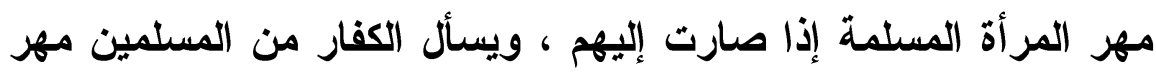

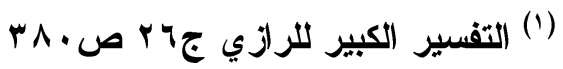

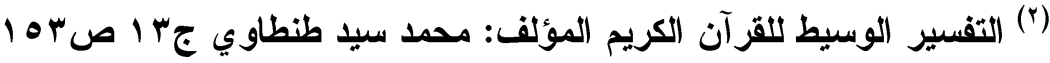

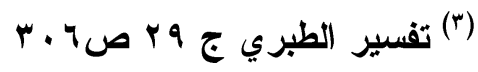




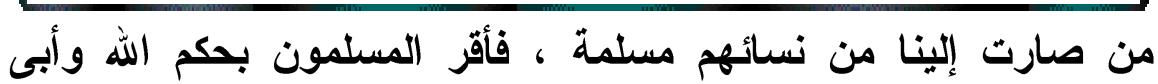

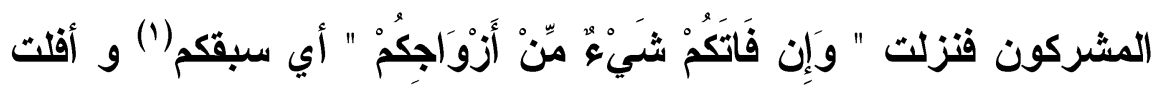

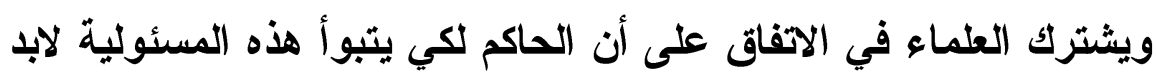

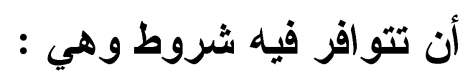

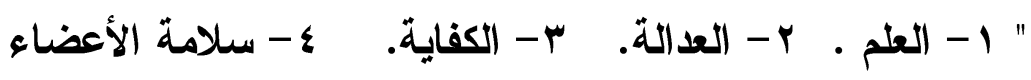

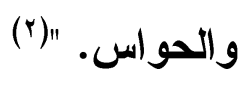

وفي هذه الثروط إيماء إلى اقتداره على تحمل تبعات الحكم ، مع التسليم بتصادم هذه الثروط مي السؤال القائل : هل يشترط في الحاكم أن يكون أفضل الناس جميعا ؟

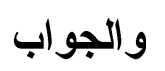

لا يشترط في الحاكم أن يكون أفضل الناس جميعا وخالف في ذلك

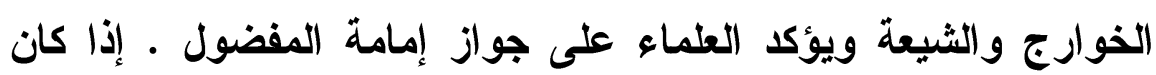
المفضول قائما بالكتاب و السنة .

ويؤكد مضمون هذه المقولة الأخيرة - إمامة المفضول - ابن حزم

بقوله : " وهذا هو الصواب ، إلا إذا كان الفضل من جميع الوجوه ...

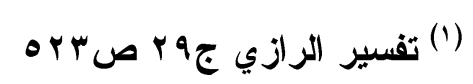

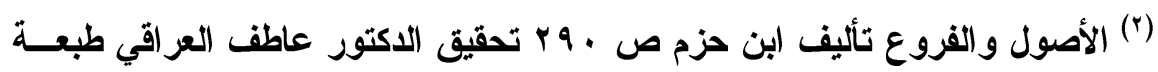

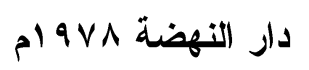


ولو كان ما قالته الطائفة الأولى - الخوارج والثيعة - صحيحا لما

صحت إمامة أبدا "(1) ومان

ويعود العلماء إلى حق الحاكم على الأمة وحق الأمة عليه بمقتضى

نيابته عنها فيقولون : حق الحاكم على الأمة هو :

$$
\text { r-الطاعة في المعروف . النصرة في الحق . }
$$

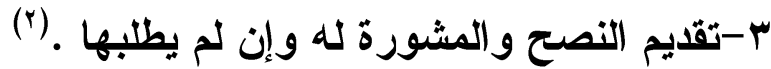

أما واجب الحاكم نحو الأمة وحق الأمة عليه فهو :

1-حفظ دينها على أصوله المستقرة ، وما أجمعت عليه الأمة .

r-حماية المسلمين من الفتن ـ وإقرار الأمن بينهم ورعايته .

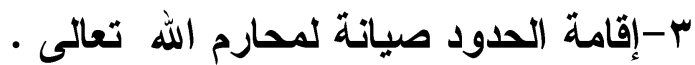

ع-تنفيذ الأحكام بين المتخاصمين ؛ لتحقيق معنى العدل ، ومنع

الظلم.

ه-حماية حدود الدولة ، وتحصين ثفورها لحمايتها من العدو الأي

يتربص بها - و

צ-الجهاد لمن يعادي الإسلام ، أو يعوق طريق الدعوة إليه .

V-تدبيز موارد الدولة ، وجباية الزكاة ، والخراج ، والفيء ،

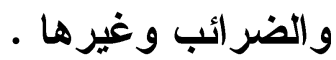

1-تصريف أموال الاولة بما يحقق العدالة ، ويراعى المصالح •

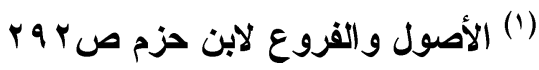

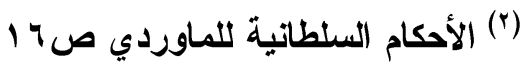


9-اختيار الأكفاء من العاملين في الاولة رعاية لمصالحها .

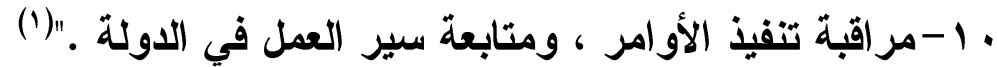

والواقع أننا لا نعاني طويلا لنفهم أن " هذه الأمور وغيرها "(؟) مما يجب على الحكام رعايتها وصيانتها .

ولا يجوز لأحد من الحكام تجاهلها ، أو التفريط فيها أو في شيء

منها.

ويتبدى بوضوح أن " النصوص الثرعية فاضت بما يجب على

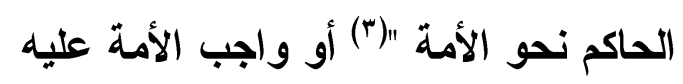

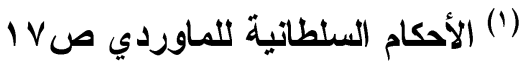

$$
\begin{aligned}
& \text { (r) (r) من واجبات الحاكم المسلم أيضا: }
\end{aligned}
$$

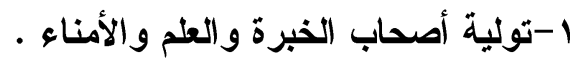

$$
\begin{aligned}
& \text { r-محاسبة الوزراء و القيادات . }
\end{aligned}
$$

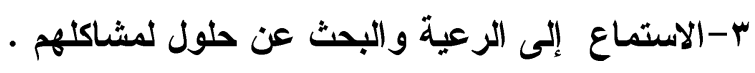

$$
\begin{aligned}
& \text { ع -استثارة أهل الحل والعقد. . }
\end{aligned}
$$

ه-حمآية العريات وكفالتها للناس جميعا.

צ-المساواة بين الناس في الحقوق والواجبات .

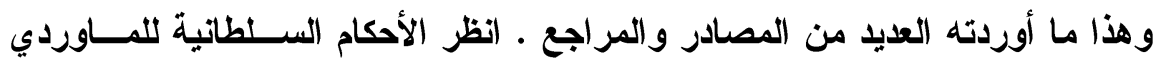

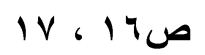

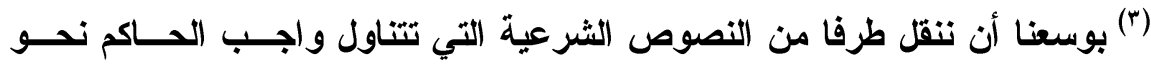

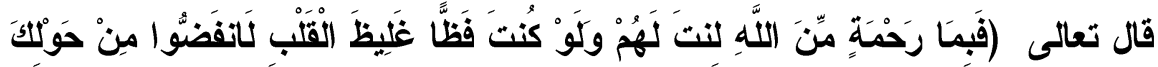

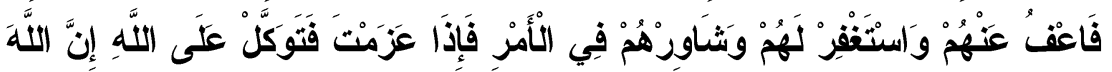

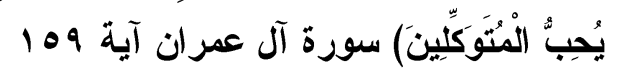

$==$ 
ولقد بدا وضَحَحُ الصبح أن تثريع قانون الدولة ، وما يحكم به الناس

من الأحكام في عقودهم وحدودهم وأعمالهم ومعاملاتهم وغيرها مما جاعت به الثريعة فهذا حق الله تعالى وحده ؛ لأنه ت تعالى يعلم المفسد

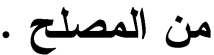

مما يؤكد أن الحاكم ، والقاضي ، والمفتي : منفذون لأحكام الله ت تعالى ومبلغون لها ووجوه الفوارق بين القضاء والإفتاء عديدة نذكر منها :

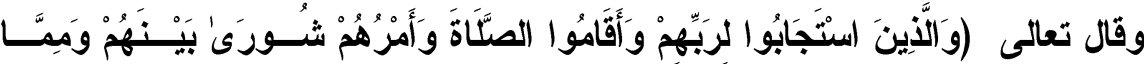

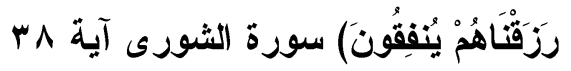

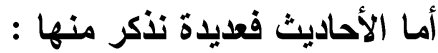

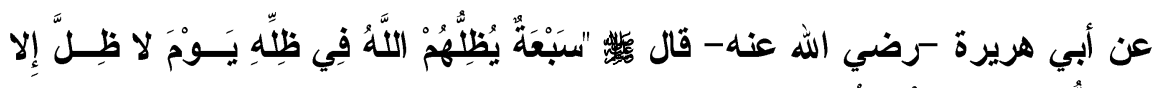

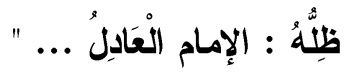

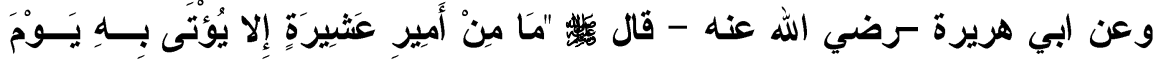

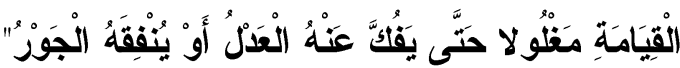

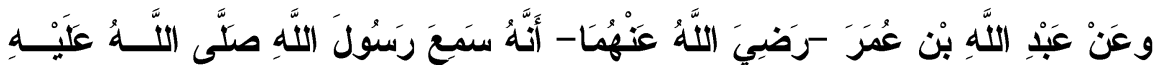

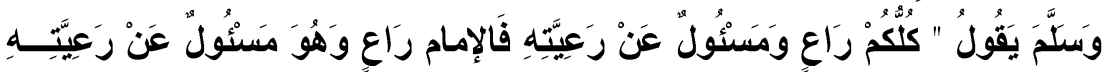

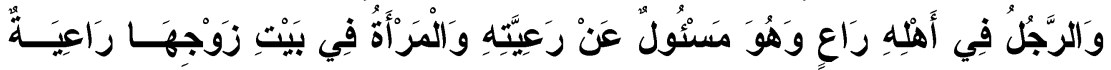

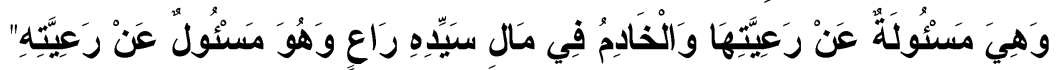

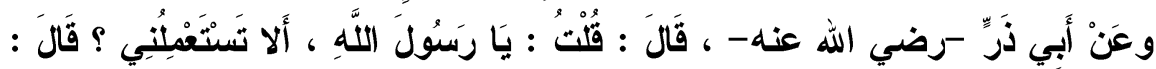

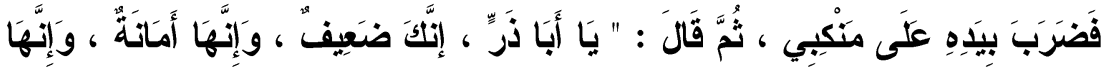

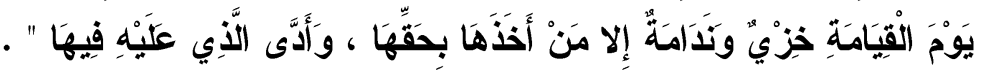


( - الإفتاء أعم من القضاء ذلك أن الفتوى تكون في العبادات وتكون في المعاملات و الآداب ... وأما القضاء يحسم فيما يقع فيه النزاع لمصالح الانيا . ب- الإفتاء والقضاء وإن كان كل منهما خبرا عن الله تعالى يلزم المكلف عموما إلا أن الفتوى إخبار محض عن الله

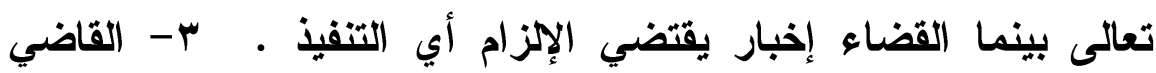
ملزما، والمفتي مخبرا. وحكم القاضي لا يتصور فيه جميع الأحكام الثرعية الخمسة - الوجوب والندب و الكراهة والإباحة و التحريم بينما يجوز في المفتي. ع - الفتوى تعتمد الأدلة الكتاب والسنة ... أما القضاء وإن كان مرجعه الكتاب والسنة إلا أنه يجب على القاضي الاستماع إلى حجج الخصوم "(1) ه- للقاضي صلاحية نقض الحكم وفسخه ، وأما المفتي فليس له شيء من ذلك...، لأن النقض لا يكون إلا لمن يكون له الإبرام "(r) فكما

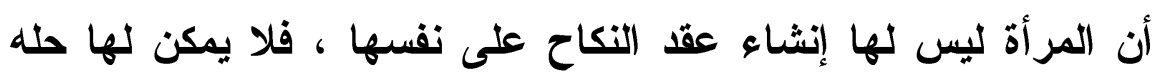
فكذلك المفتي ليس له إنشاء الحكم وليس لله نقضه . وإذا ففي التفرقة بين المفتي والقاضي والحاكم يروق لنا أن نقول: المفتي: موجه ومرشد إلى الأدلة التي لا يجوز لأحد العدول عنها

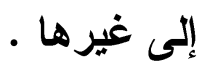

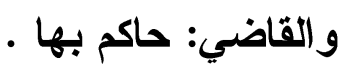
(1) الإحكام في تمييز الفتاوى عن الأحكام للقر افي ص • V طبعة مكتبــة المطبوعـات

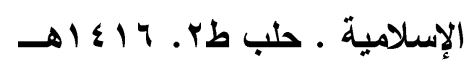

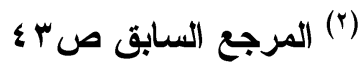


و الحاكم: منفذ لها .

والمفتي والقاضي والحاكم ينطلقون جميعا إلى قانون الإسلام يحتكمون إليه، إيمانا بأن التحاكم إلى غيره تحاكم إلى الطاغوت والشيطان... بل يصل الأمر إلى درجة الكفر إذا اعتقا صاحبه بحل ما حرم الله تعالى ، أو تحريم ما أحله ، أو تفضيل غيره عليه .

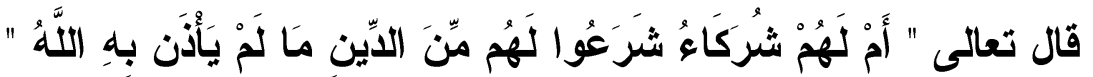

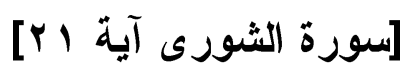

ونستطيع في مجال تحديد الاعتداء على حق الله تعالى في التشريع بتحليل أو تحريم أو غيره أن نسقط كل هذه المآخذ أهل الكتاب الأين اتخذوا أحبارهم ورهبانهم أربابا من دون الله واتبعوهم فيما أحلوا لهم

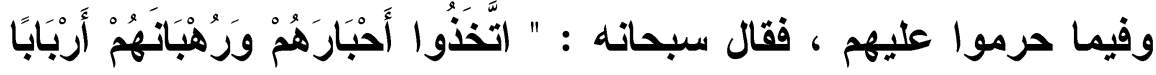

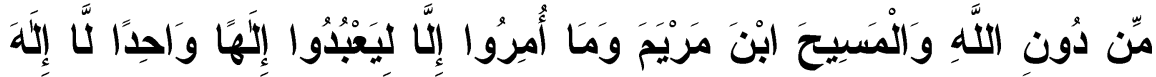

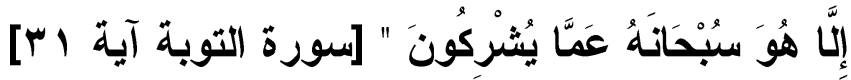
وكان أهل الكتاب يحاولون رفع أصابع الاحتجاج أو حتى أصبع تساؤل ملح · كما فعل عدي بن حاتم وقد كان الوحي المعصوم يعطيهم

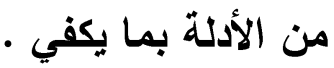

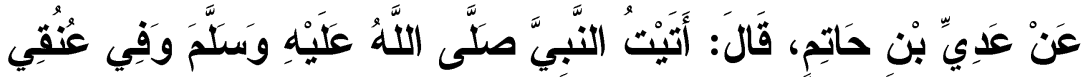

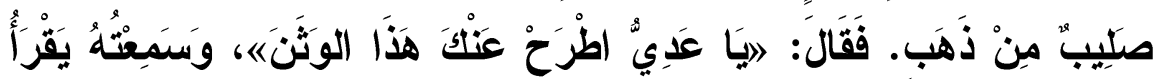
فِي سنورَةِ بَرَاءَةً: 
مجلة كلية الكراسعات الإسلإمية والعريبة بنات بنميء سويف العذد العاشر

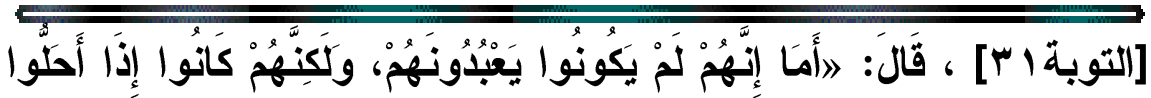

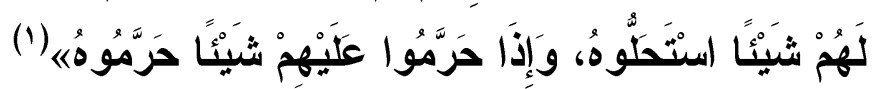

وتبلغ النقمة بالنصارى قمة اندفاعها وتأزمها حين يزعمون : أن

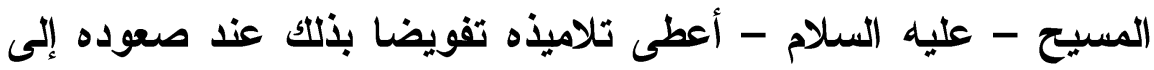

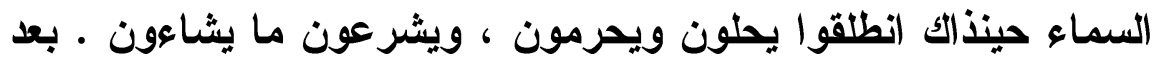

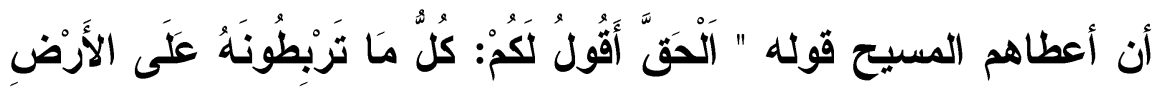

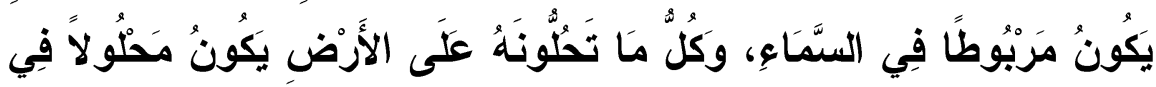

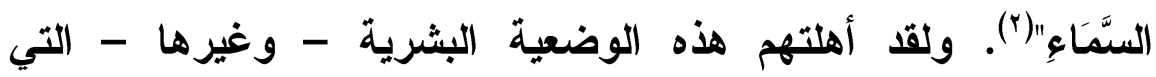
تستعصي على التصديق بها إلى قول فلاسفة الغرب وغيرهم " إذا كان التهان

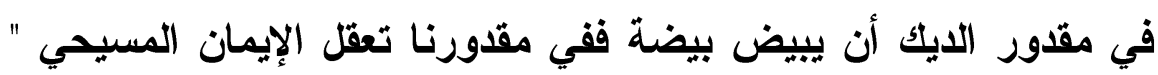

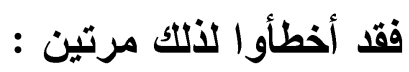

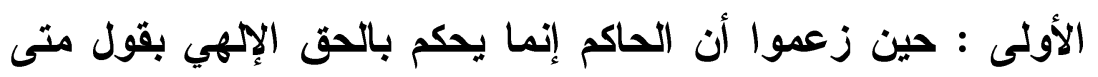

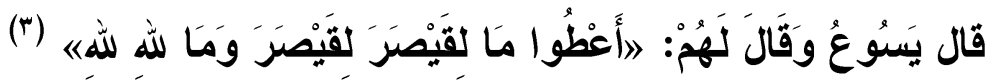
واذا كان ذلك كذلك فمن المؤكد أن النصرانية أطلقت يد الحاكم يفعل

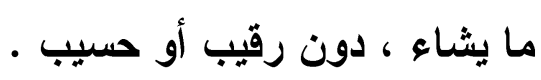
الثانية : حين زعموا أن التشريع حق الكنيسة ، لها أن تحرم أو تحل كما تثاء .

(1) أخرجه الترمذي في "جامعه"( أبواب تفسير القرآن عن رسول الله صلى الله عليه

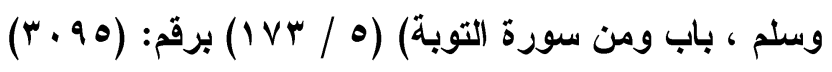

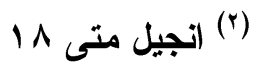

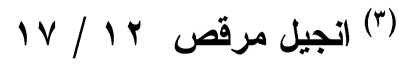


ويبدو موقفنا من النصرانية أثهر من أن يعَّرف به، فقد مسخوا الدين مسخا، وجعطوه هزوا ولعبا .

ولقد كثف القرآن الكريم كثيرا من الأقتعة التي كان أهل الكتاب

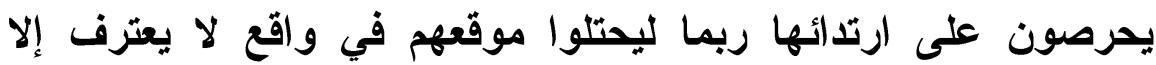
بالنصوص الثرعية المعصومة - الإسلام - قال تعالى ( قُلْ أَرَأَيْتُ مَّا

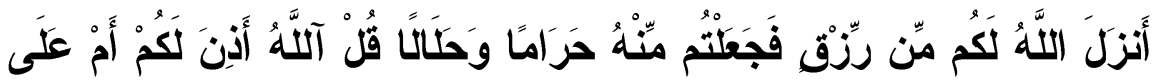

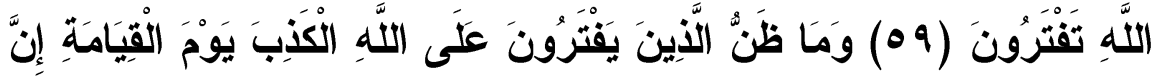

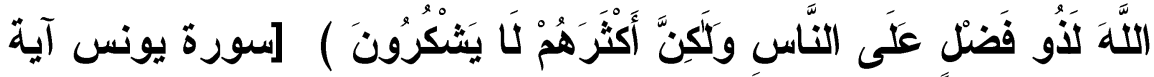
$[\because, 69$

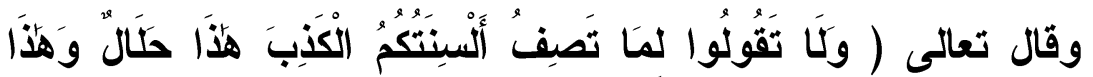

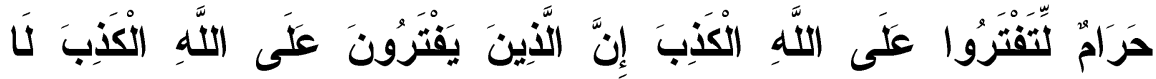

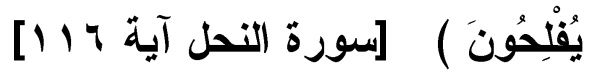
ويتبدى بوضوح أن شريعة الله التي أمرنا باتباعها وتطبيقها إما أن تكون :

1-قاّ وردت في نصوص محكمة لا تقبل صرفا ولا تأويلا أعني

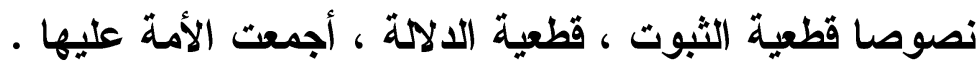

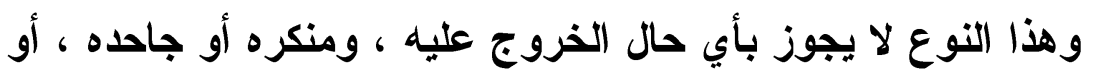
مفضل غيره عليه ، أو الداعي إلى غيره مع اعتقاده فضله على شرع

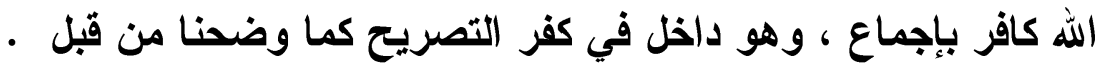
r-أما تارك شرعه تعالى، أو متبع غيره - لسبب أو لآخر - دون

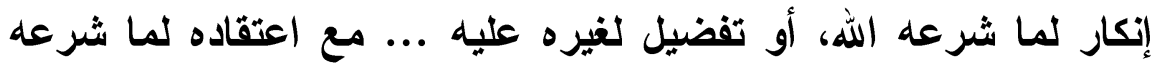


الله تعالى ، ويقينه بأن شرع الله أولى بالتصديق والتطبيق - أعني "

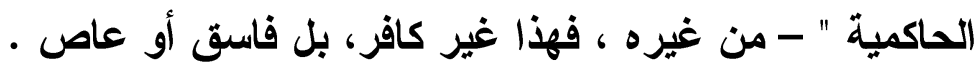
r-وأما أن تكون هذه النصوص "ظنية أو محتمله" ، وهذا النوع لا تكفير فيه كما وضحنا في كفر التأويل . ع-وإما أن لا تكون هناك نصوص أصلا ، وهذا النوع وما قبله هو

محل اجتهاد العلماء . (1) و إذا كان منطق العقل البشري يقول المخطئ في اجتهاده معذور فإن

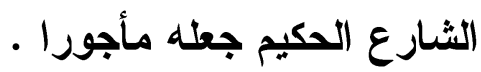

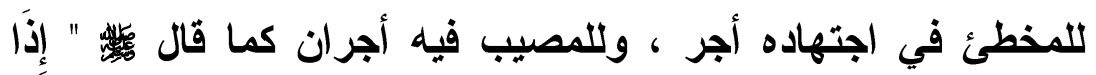

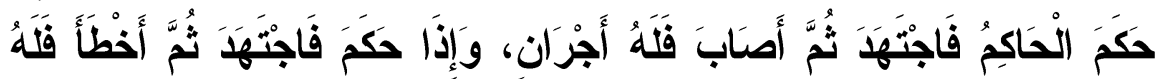

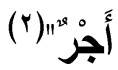

ومع ما في هذا الحديث من سعة ورحمة للمجتهرين.

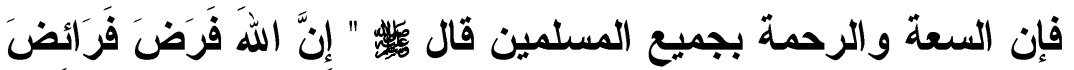

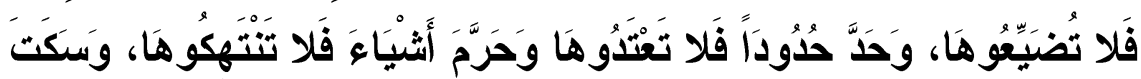

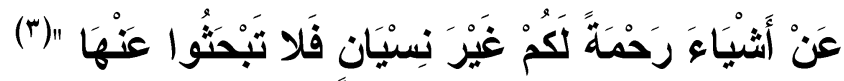

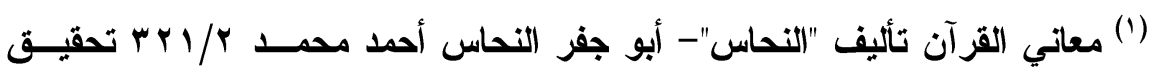

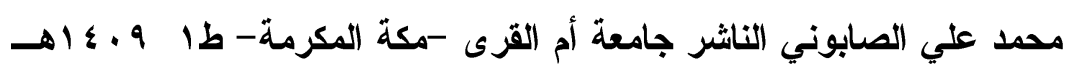

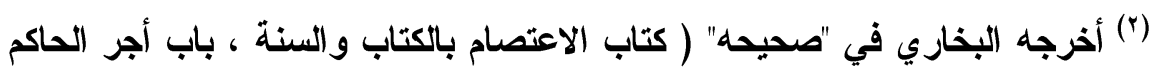

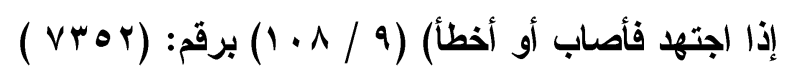

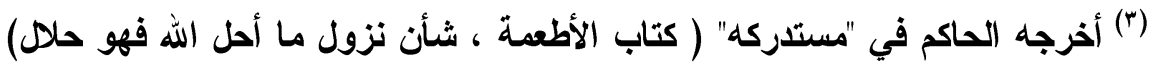

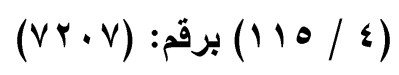


وفي النهاية يمكن فهم النصوص التي يتذذها كثيرون حجة لهم في تكفير الحكام وتكفير من تبعهم وتكفير من رضي بحكمهم ، وتكفير من لم يكفرهم ... الخ ولا نستطيع تجاوز النصوص الثرعية التي اعتمد عليها

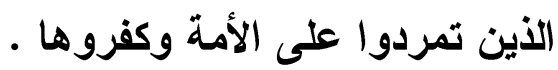

ويتبدى حس الدماثة الفكرية للعلماء الذين تصدوا لفتنة تكفير الأمة وحتى لا نغرق القضية - التكفير - في تهاويل لغوية باذخة فإننا سنستعرض النصوص الثرعية ونذكر آراء المفسرين فيها لأن جل همنا الوصول إلى قلب القضية بلا مز ايدات !!

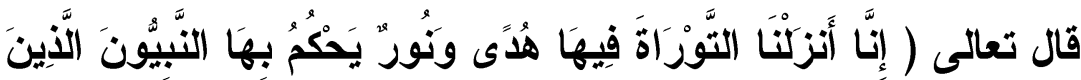

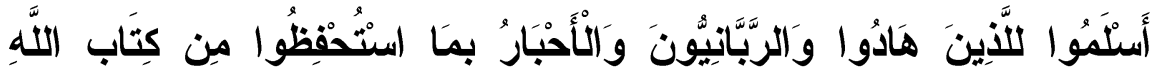

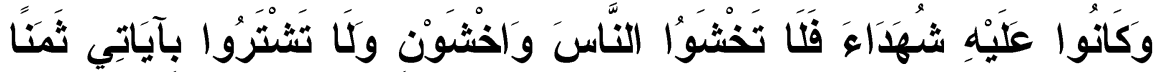

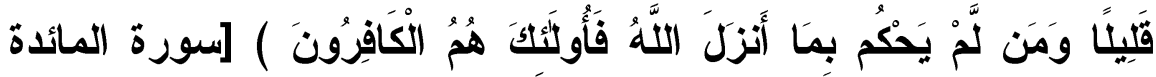

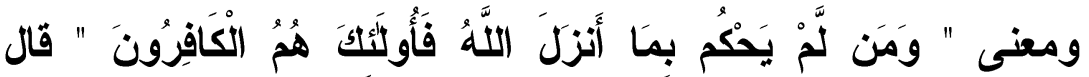

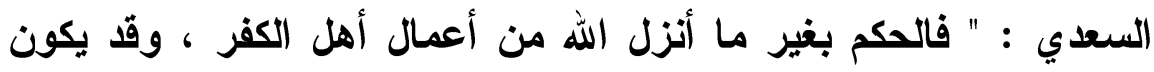
كفر اينقل عن الملة ، وذلك إذا اعتقد حله وجوازه ـ وقد يكون كبيرة من

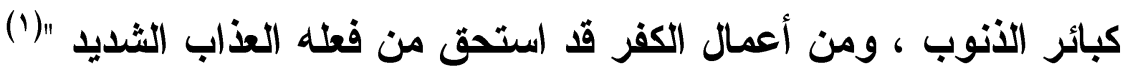
وقال الألوسي ما ملذصه " احتجت الذوارج بهذه الآية على أن

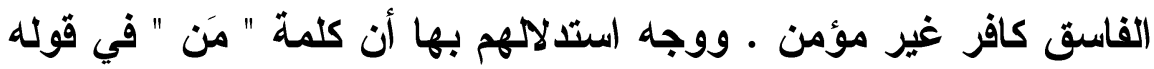

(') تفسير السعدي المسمى : تيسبر الكريم الرحمن في تفسير كلام المنان صبrT. 
" وَمَنْ لَّمْ يَحْكُم " عامة شـاملة لكل من لم يحكم بما أنزل الله فيلخل الفاسق المصدق أيضا لأنه غير حاكم وغير عامل بما أنزل الله تعالى . ويتبدى لنا أن هذه الجملة الكريمة عاملة في اليهود وفي غيرهم فكل

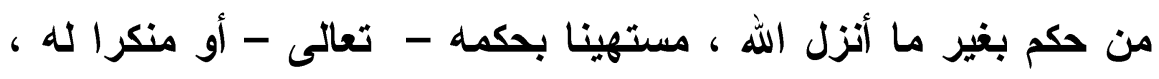
يعد كافرا لأن فعله هذا جحود وإنكار واستهزاء بحكم الله ومن فعل ذلك هلئ

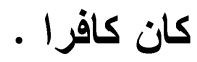

أما الأي يحكم بغير حكم الله مع إقراره بحكم الله تعالى واعترافه

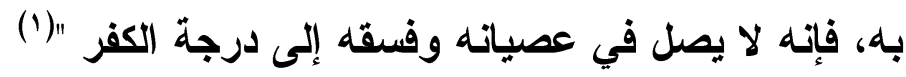
وقال البغوي:"والظالمون والفاسقون كلهم من الكافرين، وقيل: هي

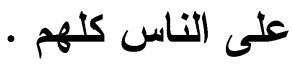
وقال ابن عباس وطاوس : ليس بكفر ينقل عن الملة ، بل إذا فعله هو به كافر وليس كمن كفر بالله واليوم الآخر • وقال عطاء : هو كفر دون كفر، وظلم دون ظلم ، وفنق دون فسث. وقال عكرمة : من لم يحكم بما أنزل الله جاحدا به فقد كفر ، ومن

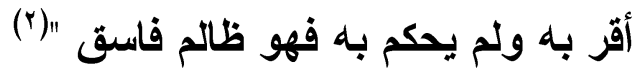
وقال ابن كثير في معنى قوله تعالَى" وَمَنْ لَّْْ يَحْكُ بِمَا أَنزَلَ اللَّهُ

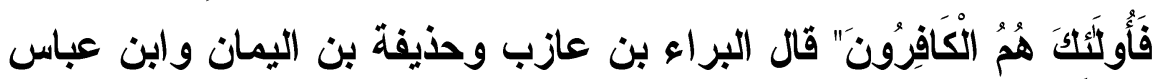

(') تفسير الألوسي المسمى روح المعاني في تفسير القرآن العظيم والسبع المثــي جr

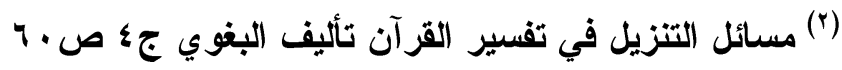


وأبو مجلز وأبو رجاء العطاردي وعكرمة وعبيد الله بن عبد الله والحسن البصري وغيرهم : نزلت في أهل الكتاب - زاد الحسن البصري : وهي علينا واجبة وقال السدي: ومن لم يحكم بما أنزلت فتركه عمدا، أو جار وهو

يعلم، فهو من الكافرين"(1)

وقال الرازي: ورأي الجمهور هو " عدم التكفير " لمجرد المخالفة أو المعصية ـ وبعد أن ذكر حجج الفريقين انتهى إلى " رأي عكرمة " وهو: أن من أنكر بقلبه وجحد بلسانه فهو كافر... أما من عرف بقلبه أن الحكم لله تعالى، وأقر بلسانه إلا أنه أتى بضده. فقد حكم بما أنزل الله تعالى ، ولكنه تارك لله ، فلا يلزم دخوله تحت هذه الآية الكريمة قال " الرازي ": وهذا هو الجواب الصحيح ، والله أعلم "(†) ولهم ولهذا يقول ابن الجوزي :

وفصل الخطاب عندي : أن من لم يحكم بما أنزل الله جاحدا له - كما فعلت اليهود - فهو كافر ، ومن لم يحكم به ميلا إلى الهوى من غير

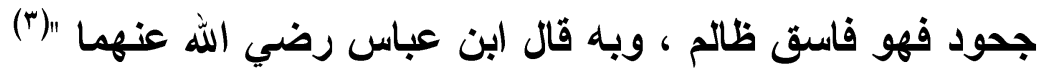

$$
\begin{aligned}
& \text { (') (بن كثير جr صץ + 1 (1) }
\end{aligned}
$$

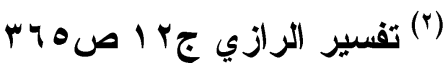

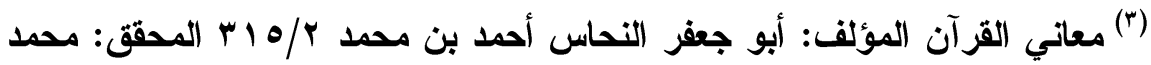

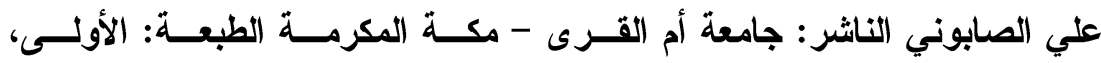

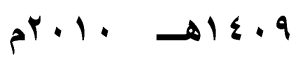


وهناك في فكر ابن تيمية ما يؤكد أن من اتبع في العمل فقط فلم

يستحل الحرام كان فاسقا ، أما من اتبع في الاعتقاد باستحلال الحرام •

وتحريم الحلال فهو كافر

يقول ابن تيمية :

" ولا ريب أن من لم يعتقد وجوب الحكم بما أنزل الله على رسوله فهو كافر ... "ومن علم " أنه لا يجوز لهم الحكم إلا بما أنزل الله ، فلم

يلتزموا ذلك ، بل استحلوا أن يحكموا بخلاف ما أنزل الله فهم كفار "(')، و أما الانوب كالزنى والشرب فلا يكفر فاعلها. وأما من ترلك الصلاة والزكاة والصوم والحج لكسل أو غيره مع إيماته بوجوب الفرائ فلا

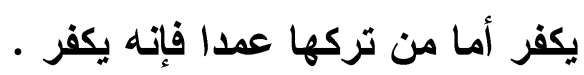
يقول ابن تيمية :

وقد اتفق المسلمون على أنه من لم يأت بالثهادتين فهو كافر ، وأما الأعمال الأربعة فاختلفوا في تكفير تاركها... قال الحاكم بن عتبة: من ترك الصلاة متعمدا فقد كفر ، ومن ترك الزكاة متعمدا فقد كفر ، ومن ترك الحج متعمدا فقد كفر ، ومن ترك صوم رمضان متعمدا فقد كفر،... وقال الضحاك: لا ترفع الصلاة إلا بالزكاة. وقال عبد الله بن مسعود: من

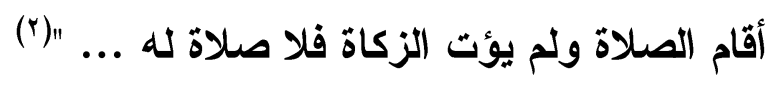

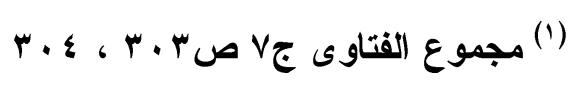

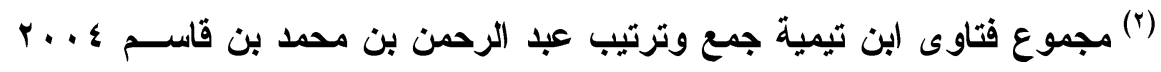

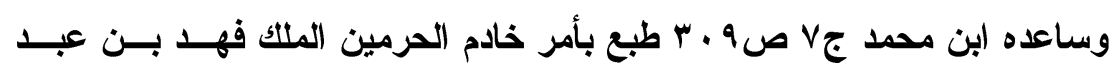

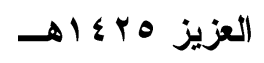


وإذن فمناط التفريق بين كفر دون كفر في الفكر الإسلامي جاء من خلال التفريق بين من أنكر الخالق وبين من آمن به وقصر أو تكاسل في

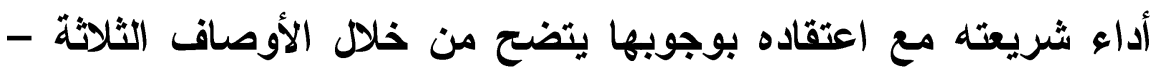
الكافرون ، الظالمون ، الفاسقون - ولولا هذه الأوصاف لذهب اعناد المتثددون بثلثي الأمة إلى الكفر .

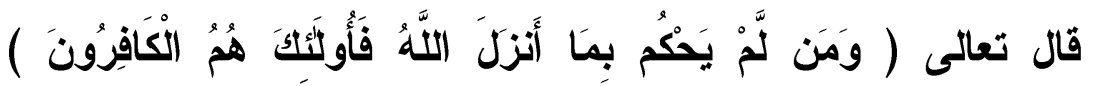

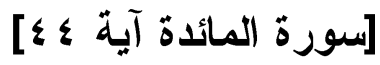

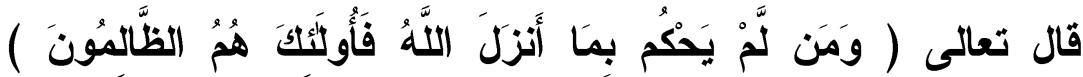

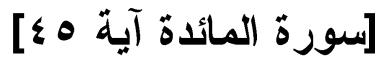

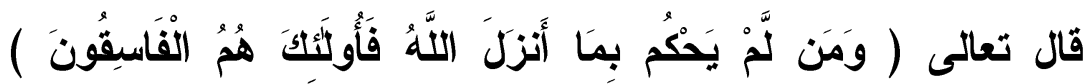

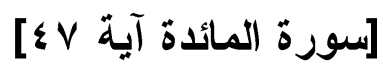
فقد جاءت الآيات لاعتبارات مختلفة :

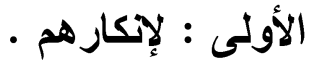

و الثانية : لوضعهم الحكم في غير موضعه .

$$
\text { و الثالث : لخروجهم عن الحق . }
$$

و الثيخ رشيد رضا يتأمل الآيات الثلاثة ويؤكد ما سبق أن أثثرناإليه - الاعتبارات المختلفة - في قوله " واذا تأملت الآيات أدنى تأمل ظهرت

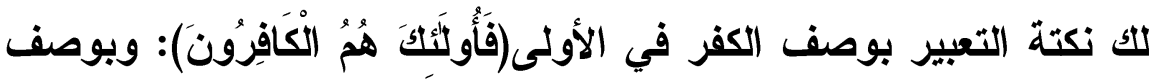
الظلم في الثانية، وبوصف الفسوق في الثالثة. ففي الآية الأولى كان الثان الكلام في التشريع، وإنزال الكتاب مشتملا على الهذى والنور، والتزام 
الأبياء والعلماء العمل به والحكم به، والوصية بحفظه، وختم الكلام

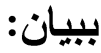

أن كل معرض عن الحكم به لعدم الإذعان له رغبة عن هدايته

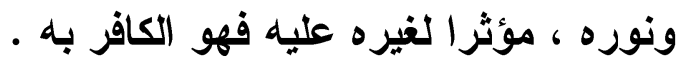

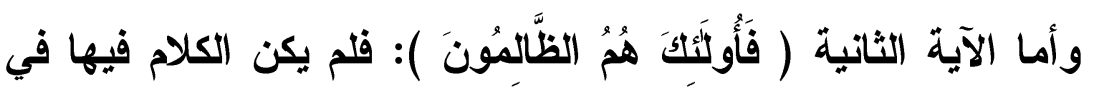
أصل الكتاب الأي هو ركن الإيمان ، بل في عقاب المعتدين على الأففس ، أو الأعضاء بالعدل والمساواة ، فمن لم يحكم بذلك فهو الظالم في حكمه كما هو ظاهر - ماهر

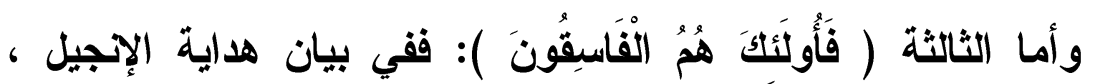
وأكثرها مواعظ وآداب ... فمن لم يحكم بهذه الهداية ممن خوطبوا بها

فهم الفاسقون بالمعصية والخروج من محيط آداب الثريعة "(1) ويتبدى بوضوح أنه يمكن حمل ما ورد من النصوص التي تفيد عدم الإيمان لعدم الحكم بما أنزل الله ، أو بما حكم به الله ورسوله ، كقوله :تعالمى :

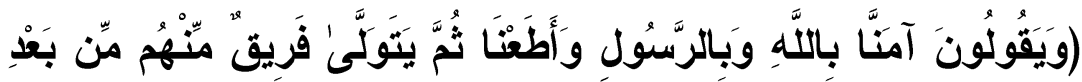

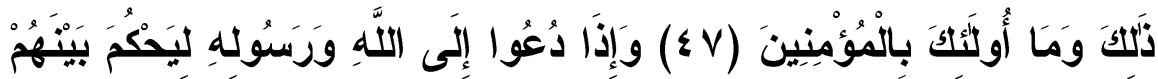

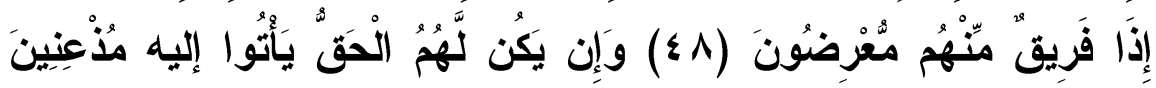

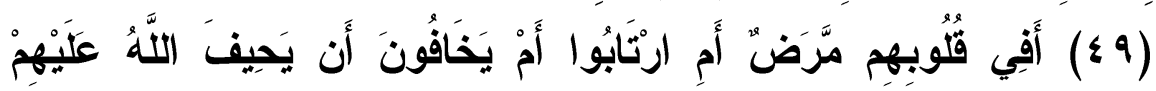

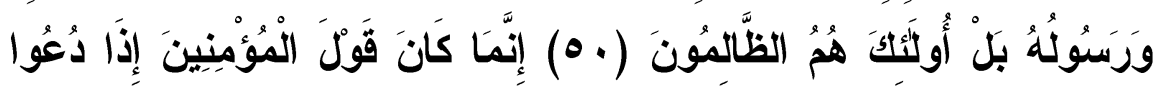
(1) هذا بيان للناس تأليف الثيخ جاد الحق علي جاد الحق الجـزء الأول صه V ط ط

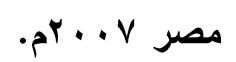




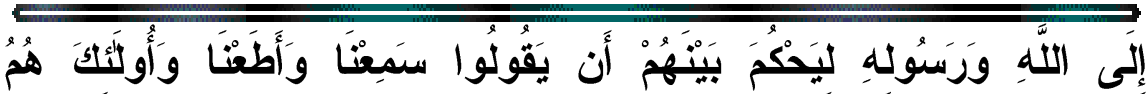

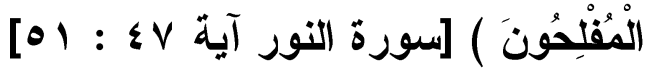

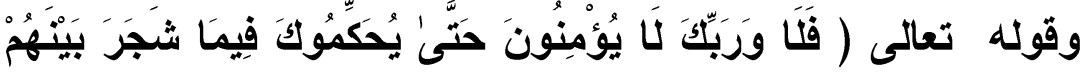

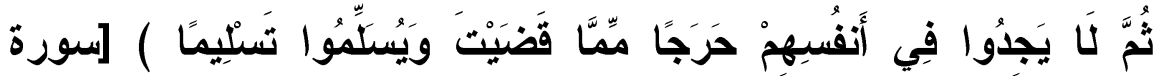

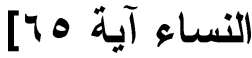

ولقد أفلح العلماء في فهم قضية الحاكمية لأننا إذا حاصرنا الكلام في

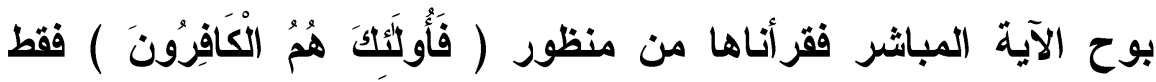

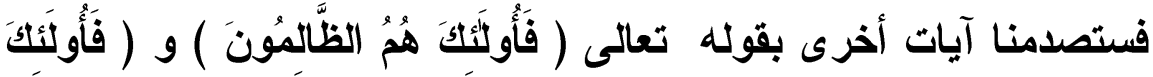

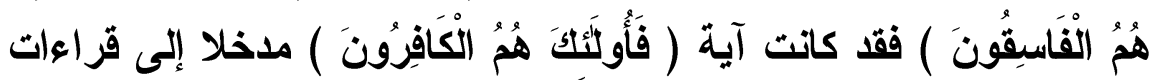

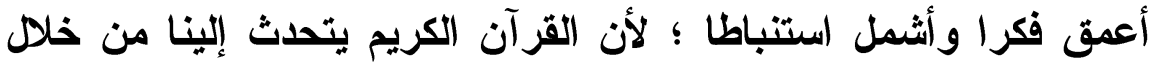

اعتبارات عديدة وليس من خلال مستوى واحد بلا تعدد !!

وكان التحقيق على أن من لم يحكم بما أنزل الله كفرا به ، أو جدا له ، أو لزعمه عدم صلاحيته للعصر ، أو الاستهزاء به ، أو ما شابه لزيه

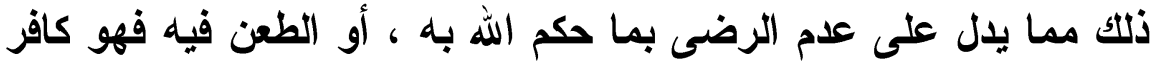

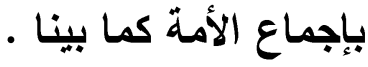

ولأنا هنا وهناك نهتم دائما بأن نصدر حكما ... ويأن نقبل أو ندين... وبأن نكون قضاة النص لا مجرد أصدقائه فحسب فنتنكر الأثر

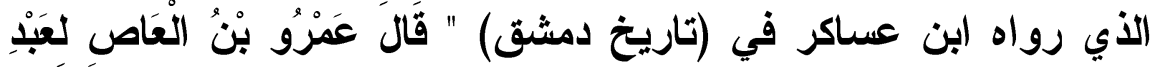

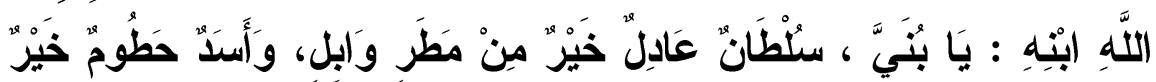

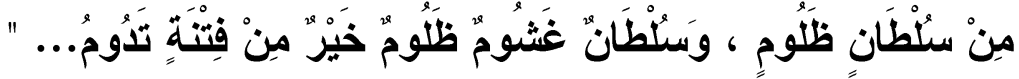




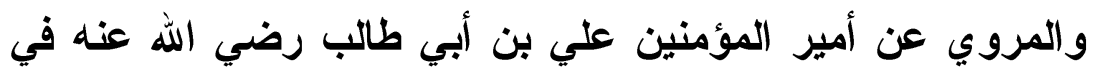

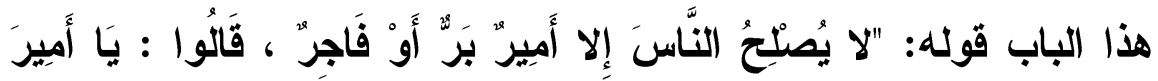

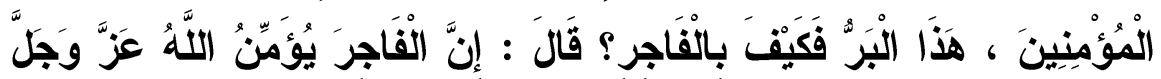

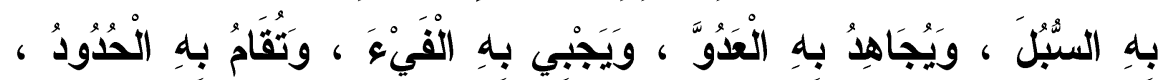

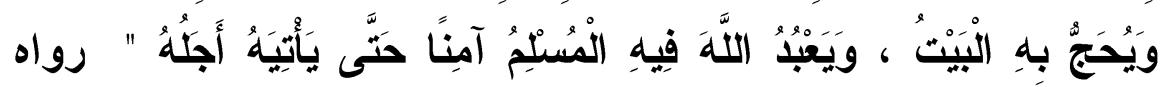
البيهقي في (شعب الإيمان). 


\section{وتخليص تلخيص}

وقفة مع أهم شبهات الدواعش وقادتها من الجماعات المتطرفة فــي

قضية الحاكمية والتشريع :

هناكك "ثبه اتفاق"(') - بين العلماء - على أن الــدواعش وقادتهـــا

ضلوا وأضلوا كثيرا من شباب الأمة، وإذا كان البغدادي قائدهم إلى النار

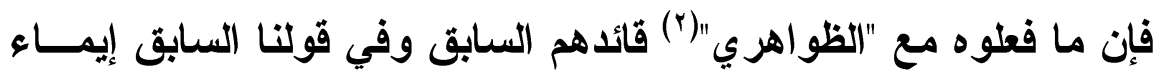
إلى اقتاره الفكري بوأه السبق لهذه الزعامة، مع التسليم بتصادم هــــه الزعامة الفكرية مع الحس الايني الأي عرفه ووقع عليه وكان سببا في هروبه منهم.

وللاواعش وقادتها من الجماعات المتطرفة شبهات لا تنال من الأمة

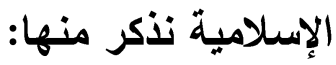

الشبهـة الأولى: "الثجاعة والإقدام الأي يوجد في رجـال داعـش

وقادتها من الجماعات المتطرفة يدل على إيمان ويقين"(ّ).

وهنا نتساعل:

شبه اتفاق: أعني لم يخرج عن اتفاق العلمــاء إلا أصـــاب الهــوى. وأربـــاب

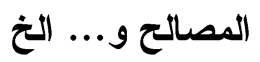

الظواهري هو القائل: البغدادي أعطى إيران حجة لإبادة السنة في العراق. أنظــر

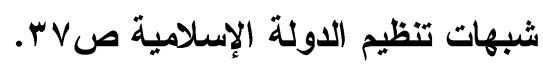

شبهات تتظيم الدولة الإسلامية وأنصاره والرد عليه. إعداد الاكتور عماد الــدين

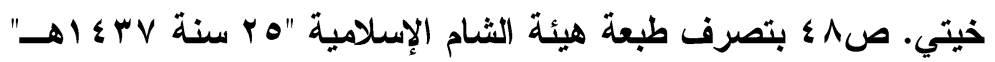


هل تشريد الدواعش للأمنين في العراق وسوريا وليبيا وغيرها مسن الدول واغتصابهم بل قتلهم دليل على إيمان ويقين ؟!

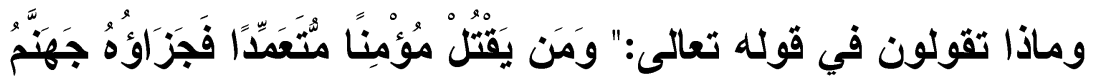

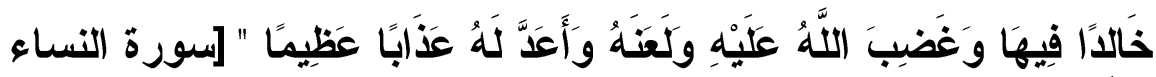
آية س

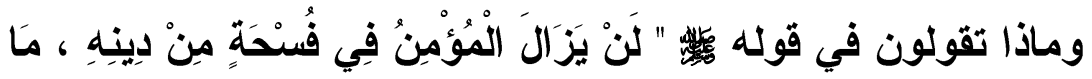

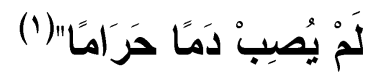

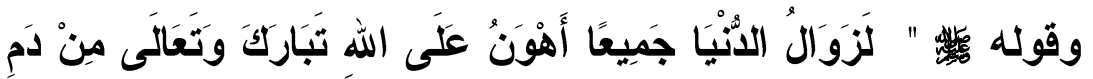

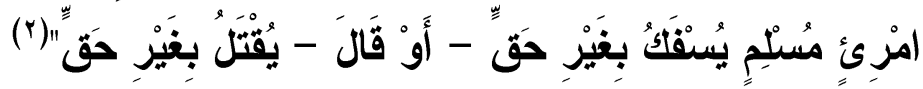
لقد ظل ابن حزم قادراً على نقلنا إليه من خلال انتقاله إلينــا حـين أعطى "كل من وافق الخوارج في آرائهم ومبــادئهم الأسـاســية فــي أي علي عصر من العصور لقب الخوارج يسمى خارجيا لمواققته لهم"(") ويتبدى حس القبض على أخطاء الجماعات التكفيرية في قول ابـن

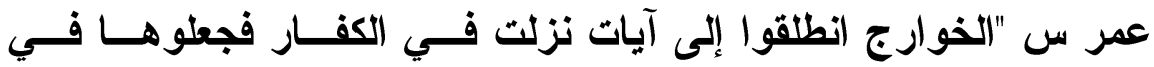

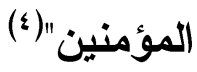

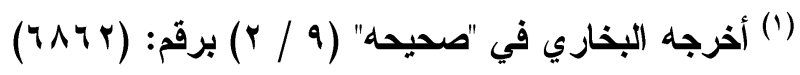

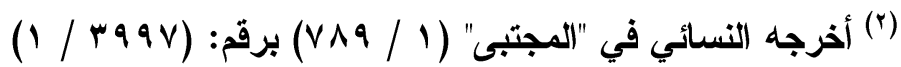

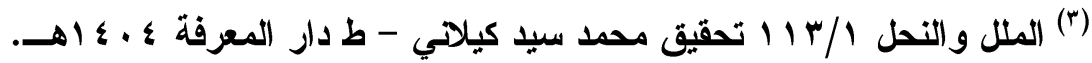

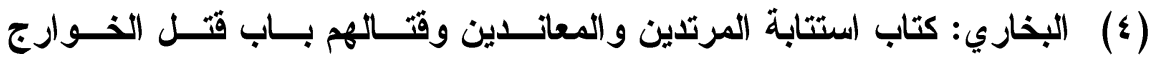
و والملدين 
وابن تيمية قد نال من الجماعات التكفيرية حتى أوجعها تماما حسين

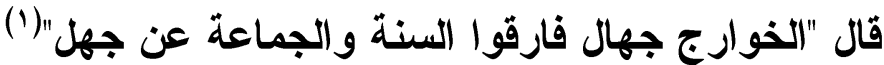

ويبدو موقف الإمام علي س من الخوارج أثثهر من أن يعرف به فقد

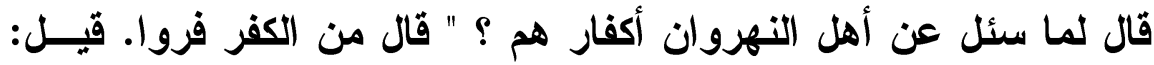
أفمنافقون ؟ قال: إن المنافقين لا يذكرون الله إلا قليلا. قيل: أمؤمنـــون؟ هرن

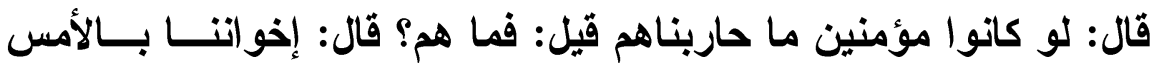

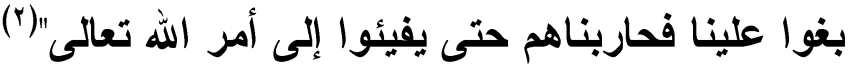

إن خوارج هذا العصر من الدواعش والجماعات المتطرفــة امتــداد

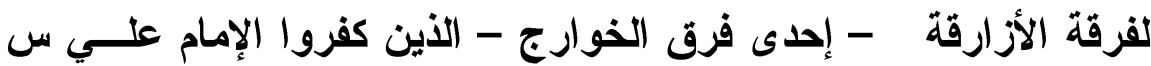

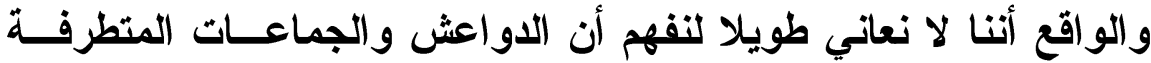
تجاوزوا الأزارقة في اعتقادهم أن من لم يهاجر إليهم ويعتنق مبـادئهم كافر وهذا هو "التكفير و الهجرة".

\section{الشبهة الثانية : للدواعش وغيرهم}

أنتم تسكتون أو تجاملون طواغيت قـــــــــــار الإســلام والــــعاة

وسجنوا المصلحين، فكيف نقبل نقدكم في الدواعش و أميرها؟(") الإدات والجواب على مرمى حجر كما يقولون:

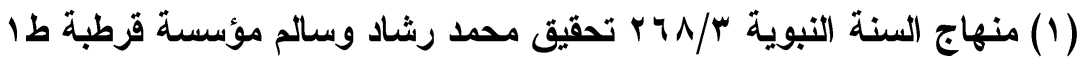

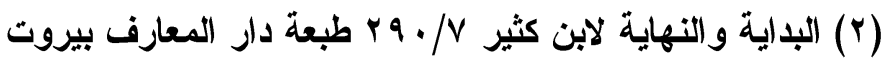
شبهات تنظيم الدولة الإسلامية وأنصاره والرد عليه. إعداد الاكتور عماد الــاين

$$
\text { خيتي. صنه }
$$


أولا: هل فساد حاكم أو أكثر يلزمه فساد كل الحكام؟! ثانيا: الحاكم الأي قتل عالما أو داعية أو كليهما. يقتل خوفا على

وأنتم قتلتم الألاف وشردتم الملايين من الأبرياء لماذا؟ أثورتكم على الظلم والطغيان قتلت حاكماً أم قتلث الأبرياء؟! مع العلم بأن هذه ليست دعوة لقتل الحكام لأكم أثبتم بما لا يلاع مجالا للثـــــ أن

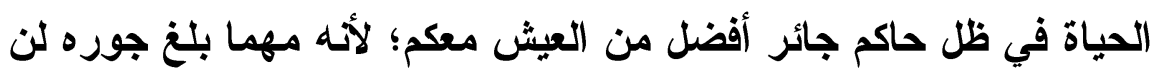

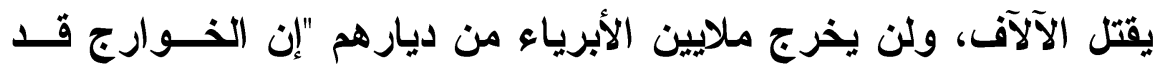
استباحت قتال الناس ومحاربتهم في صورة الأمر بالمعروف والنهي عن

(المنكر" (1) (1)

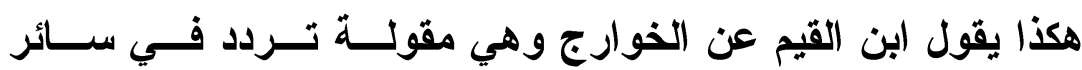
الكتابات التي تناولت الخوارج فكل المؤرخين على وجه التقريب يشيرون إلىى أن خوارج هذا العصر يمرقون من الاين كما يمسـرق الســهم مــن

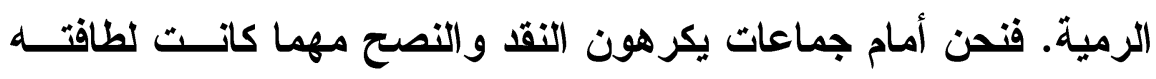
وقوة حجته وسنده من الاين.

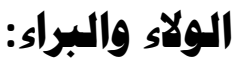

أعتقد أن قضية الولاء للمسلمين ، والبراء من الكافرين ، وما تعاورها من تأويلات ظلت تعني في أذهان المتلقين - المسلم و الآخر إغاثة اللاهفان من مصايد الشيطان تأليف ابن قيم الجوزيـــة صـ ؛ ؛ ـ تحقيـق

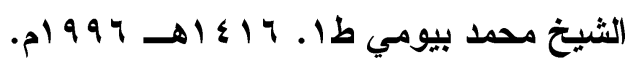


نوعا من البعد عن المخالفين في الدين وما ترسمه من حرب دائرة بين المعكرين ـ فقد زحفت إلى عقول المختلفين ضرورة القتل والاعتداء

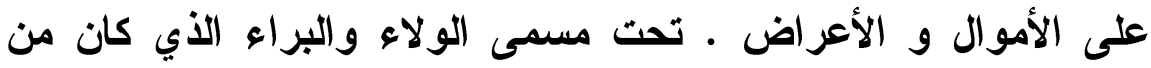
نتائجه صراع الحضارات - الغربية والإسلامية - ونعود الى لفظتي الو لاء و البراء لنعرى معناهما اللغوي والاصطلاحي لنرى مدلولهما ـ قبل أن نرى ما خلفه هذا اللفظ - الولاء- وذلك اللفظ - البراء - من ندوب وأخاديد ؛ بسبب الأخذ بطرف واحد من النصوص الثرعية وقبل الولوج إلى التأكيد على وضعية النصوص الثرعية ووحدتها نقول : الولاء في التيان

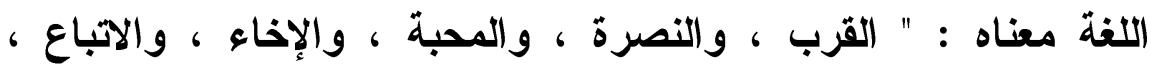

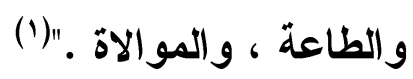

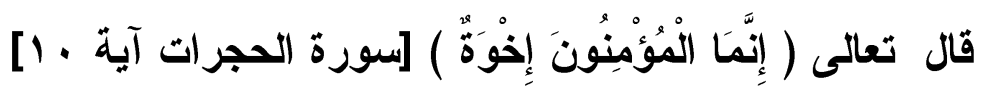

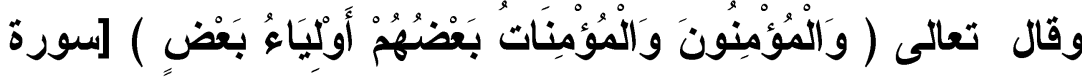

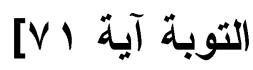

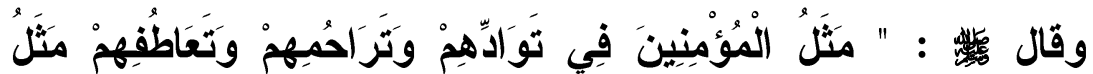

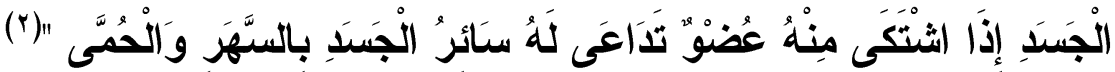
و البراء في اللغة معناه : " البعد ، و التظلي ، و التنزه ، و والتخلص."(")

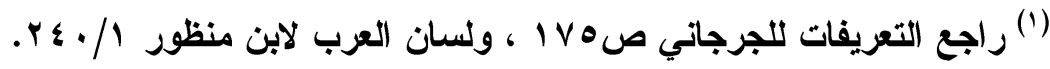

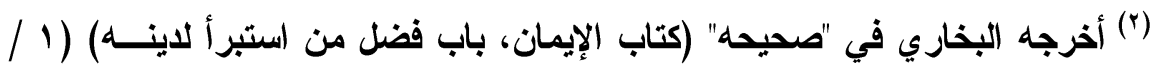

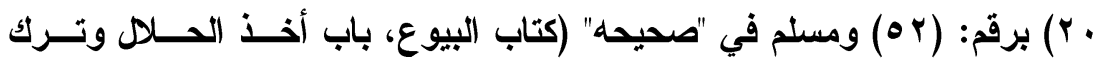

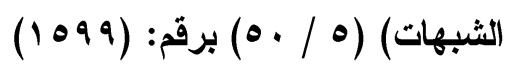

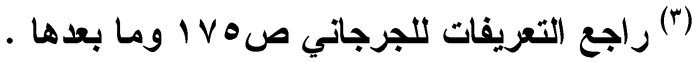




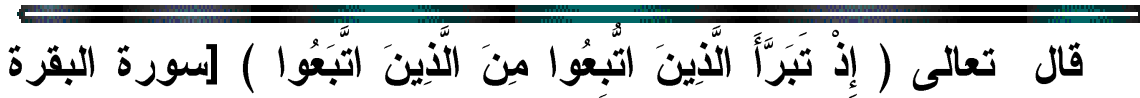

$$
\text { [آية }
$$

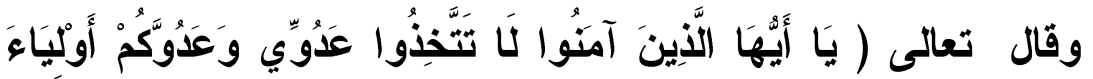

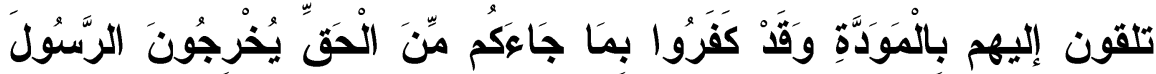

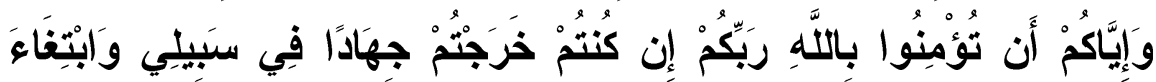

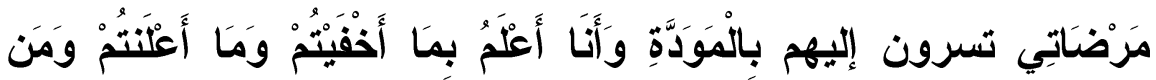

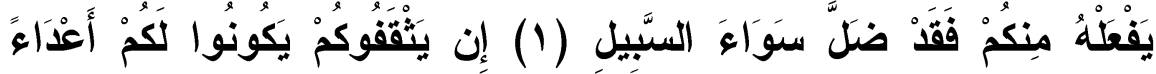

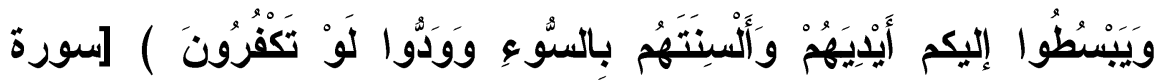

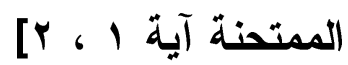

الولاء والبراء شرعا : " معناهما لا يبعد كثيرا عن المعنى اللغوي فالولاية هي النصرة والمحبة والإكرام والاحترام والكون مع المحبوبين ظاهر ا وباطنا

والبراء : هو البعد والخلاص والعداوة بعد الإعذار والإنذار ."(1)

$$
\text { أهمية الولاء و البراء : }
$$

$$
\text { 1-الولاء و البراء شرط في الإيمان : }
$$

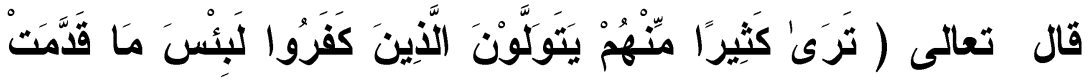

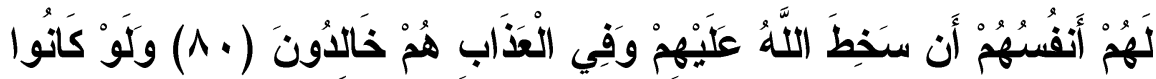

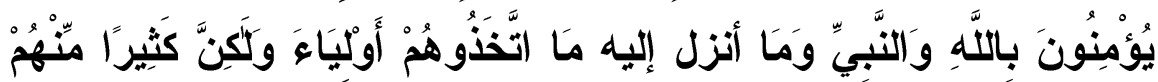

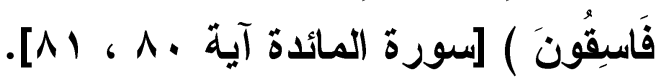

$$
\text { (') شرح العقيدة الطحاوية صץ + ؛ }
$$


الولاء والبراء أوثق عرى الإيمان :

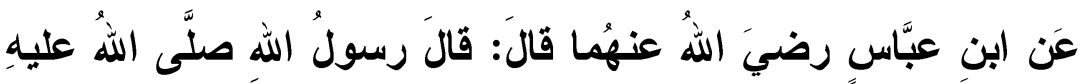

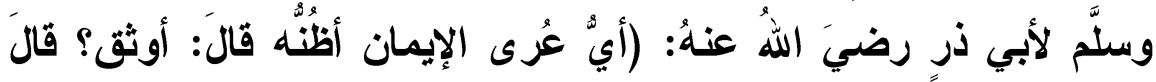

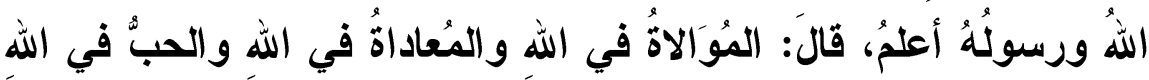

والبُغضَ في اللهِ) (1)

\section{أقسام الموالاة:}

\section{تنقسم الموالاة إلى قسمين :}

ا-موالاة مطلقة عامة ، وهذا كفر صريح ، وهي بهذه الصفة مرادفة لمعنى التولي - كفر يخرج من الملة - وعلى ذلك تحمل الأدلة الواردة في النهي الثديد عن موالاة الكفار ، وأن من والاهم فقد كفر ـ r-موالاة خاصة : وهي موالاة الكفار لغرض دنيوي مع سلامة الاعثقاد ، وعدم إضمار نية الكفر والردة كما حصل من حاطب بن أبي بلتعة - رضي الله عنه - في إفشاء سر رسول الله في في غزوة مكة ، كما جاء في سبب نزول سورة الممتحنة . ويتبدى بوضوح أن ما ورد في شأن حاطب بن أبي بلتعة في أول

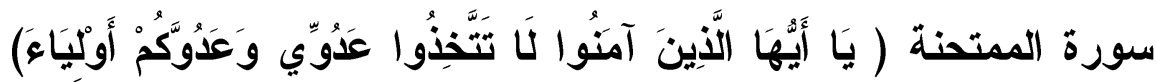
[سورة الممتحنة آية 1] وما أحد من الصحابة فعل مثل ما فعل حاطب - إفشاء سر رسول الله

$$
\text { (1) المعجم الكبير للطبراني ج) I Orv برقم }
$$


الآيات القرآنية الكريمة ناطقة بإيمانه فقد أدخلته في جملة المؤمنين بل قبل أست اعتذاره ولم يخرجه من دائرة الإسلام . ويبدو الفرق شاسعا وكبيرا بين صور ومظاهر الولاء والبراء من الكفار والمشركين والمنافقين في القرآن الكريم ، وبين طبيعة المعاملة الحسنة التي كان

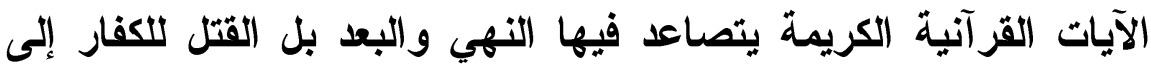

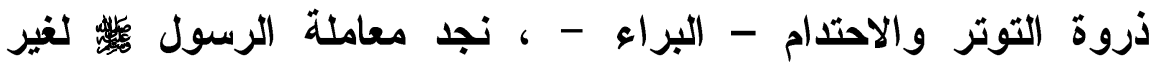
المسلمين تناسب في سهولة وانفراج وهذا ما فطن إليه العلماء ... وتخلى عنه كثير من العامة في فكرهم... وتظلى عنه المأجورون الأين أقنعوا العامة بكل انحرافاتهم الفكرية ، وجسدوا للفكر آيات قر آنية كريمة فئه

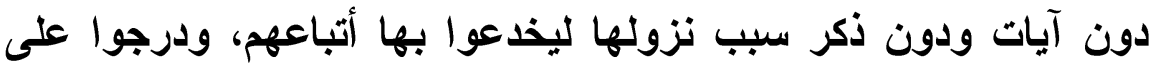

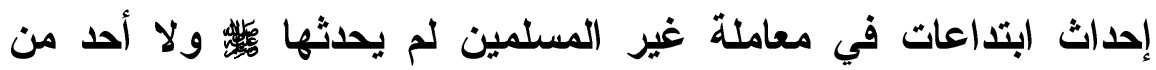

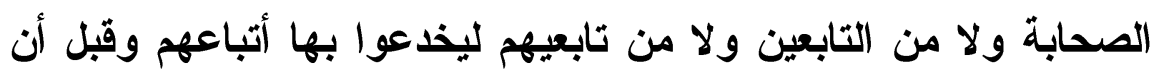
نذكر الحقيقة التي تلوح لنا في النصوص الثرعية - القرآن الكريم والسنة النبوية القولية والفعلية - نبأ بالمقدمات قبل أن نقرر أحكم

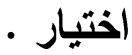

\section{أولا : صور ومظاهر الولاء والبراء لغير المسلمين}

1 - من صور ومظاهر الولاء للكفار والمشركين والمنافقين المنهي

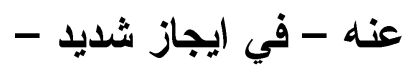

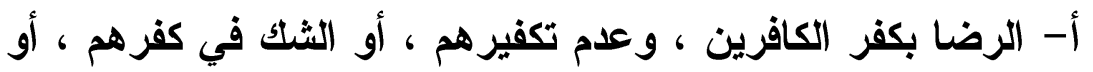

تصحيح مذهب من مذاهبهم الكافرة . 


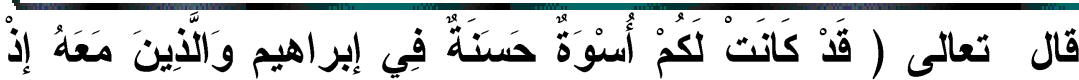

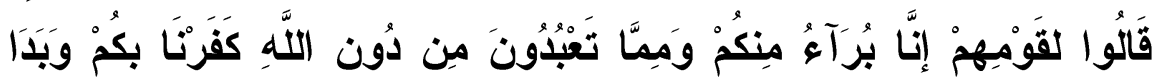

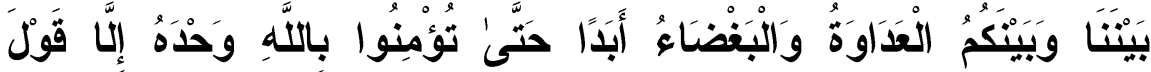

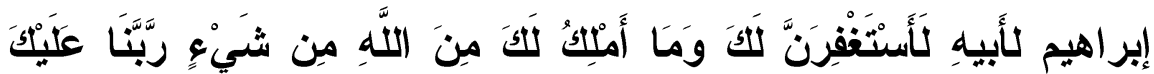

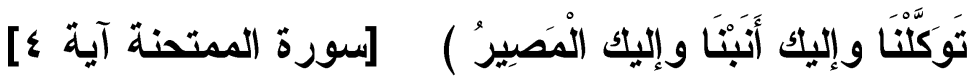

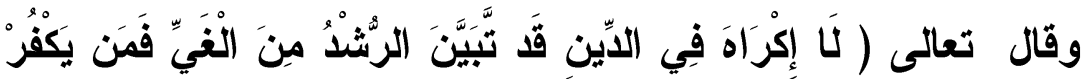

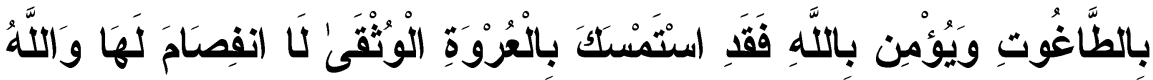

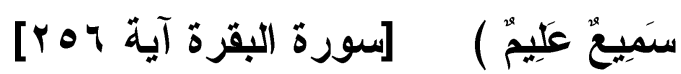
ب-التولي العام واتخاذهم أعوانا وأنصار وأولياء او الاخول في الئ دينهم .

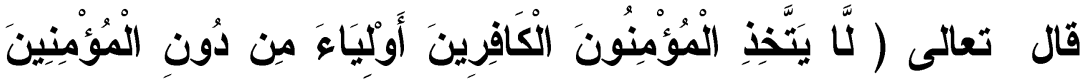

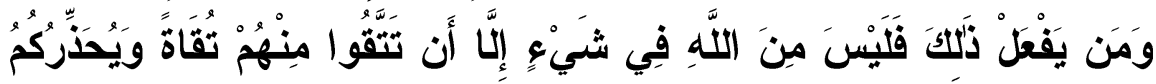

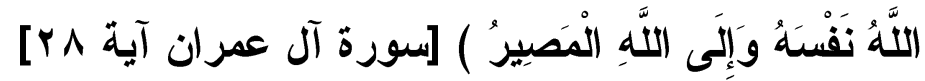

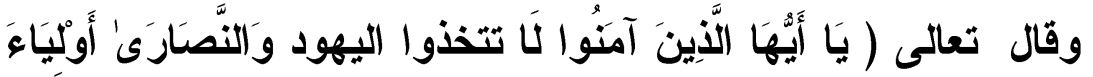

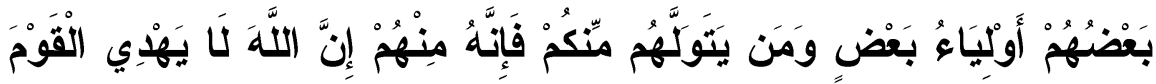

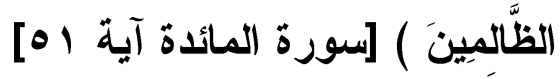

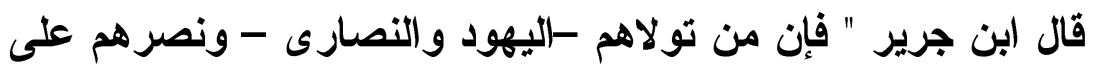

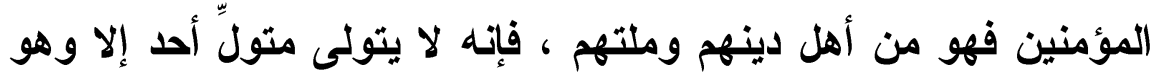

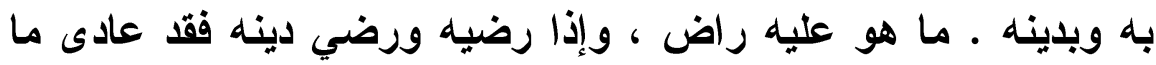

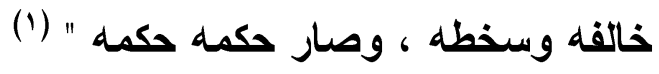

(") جامع البيان عن تأويل آي القرآن تأليف الطبري TVVV 
ج- الإيمان ببعض ما هم عليه من الكفر ، أو التحاكم إليهم دون

قال ابن تيمية " ومن جنس موالاة الكفار ذمّ الله بها أهل الكتاب

والمنافقين الإيمان ببعض ما هم عليه من الكفر أو التحاكم إليهم دون

كتاب الله "(1)

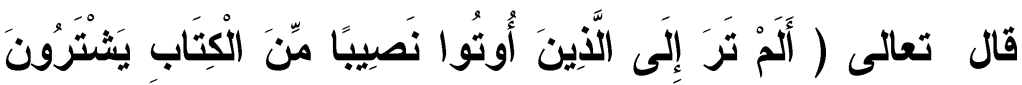

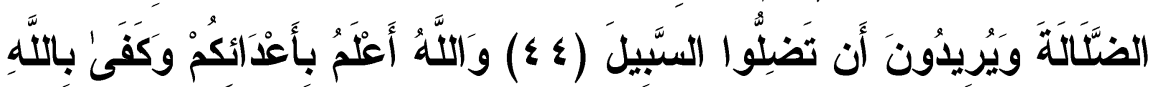

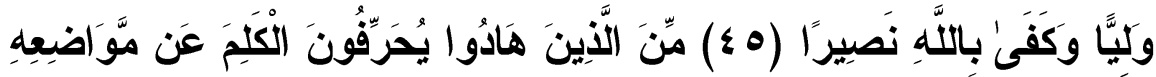

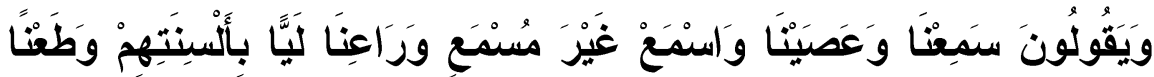

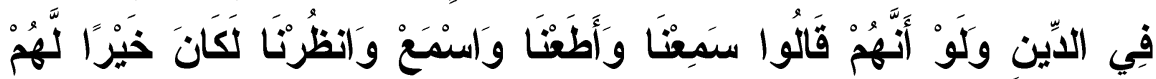

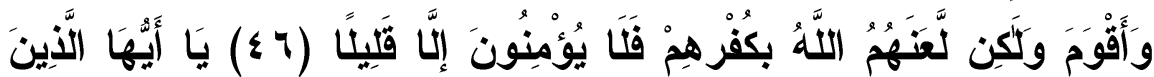

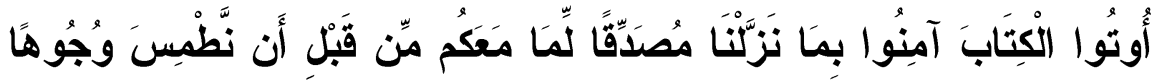

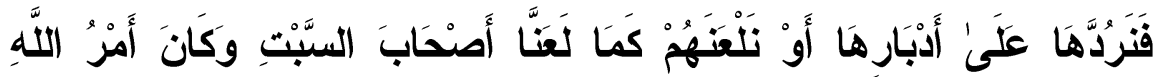

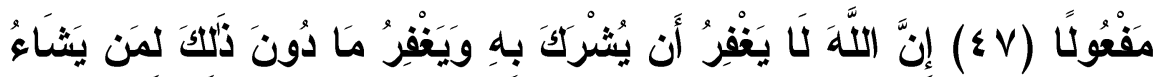

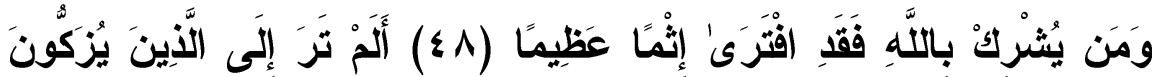

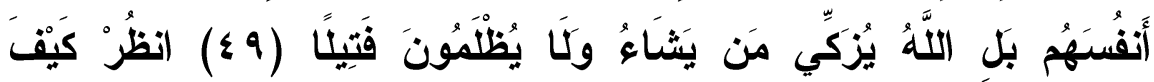

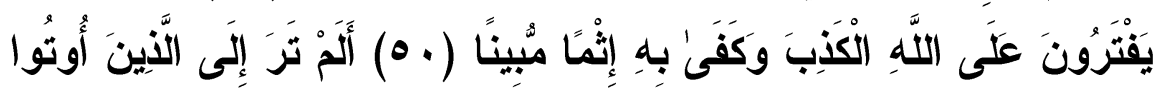

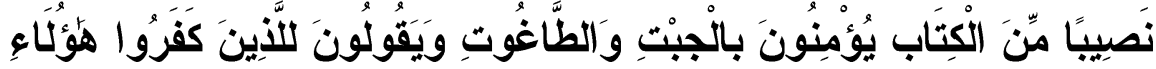

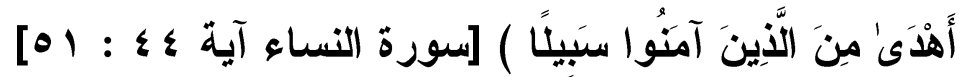


د- المحبة و المودة الخاصة :

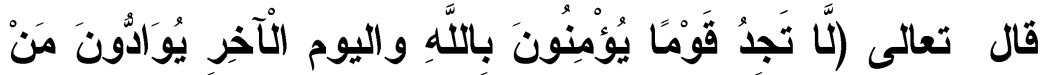

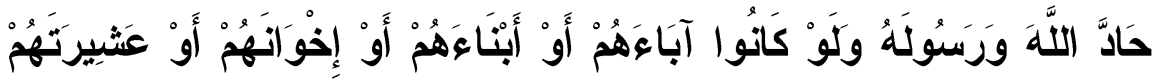

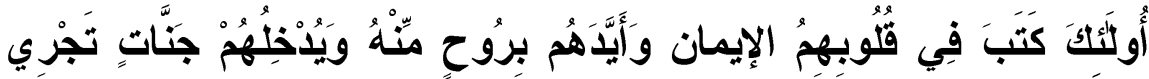

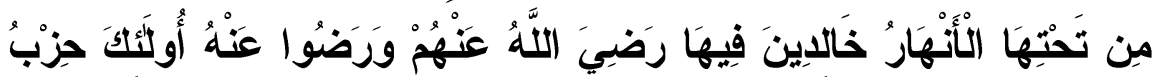

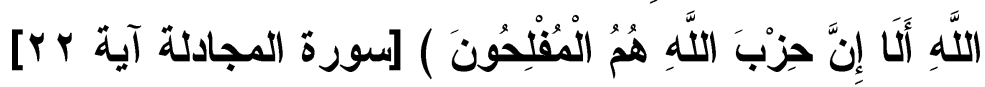
هـ- الركون إليهم :

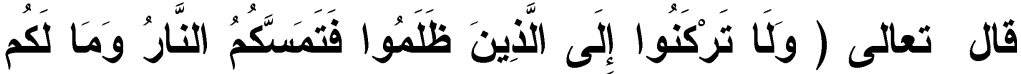

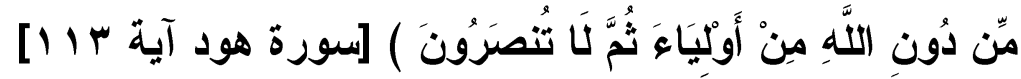
و - اتخاذهم بطانة من دون المؤمنين :

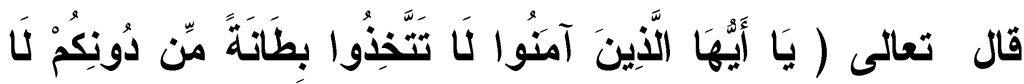

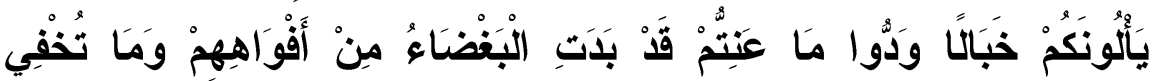

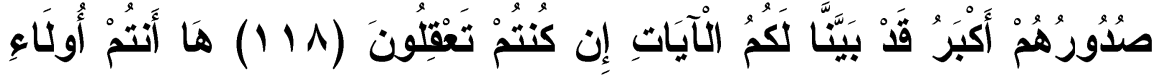

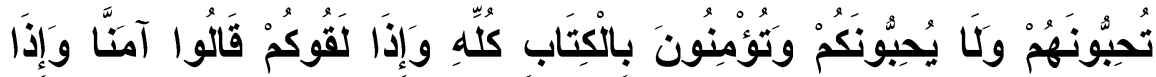

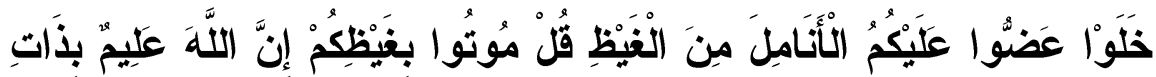

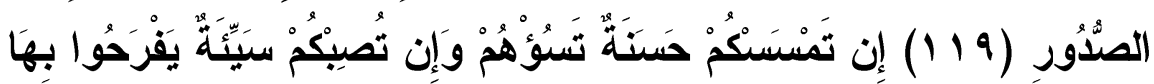

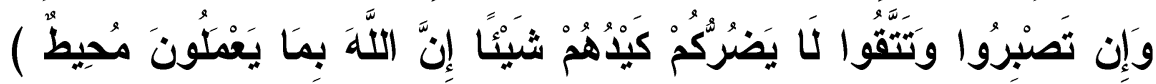

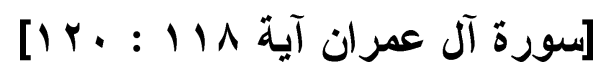

ويطول بنا القول لو مضينا نستقصي صور الولاء لغير المسلمين فمنها أيضا :

1 -الرضا بأعمالهم أو التشبه بهم والتزيي بزيهم • r-مداهنتهم ومدار اتهم • 


$$
\text { r-مشاورتهم في الأمور • }
$$

ع -إعانتهم ومناصرتهم على المسلمين ومدحهم و الأب عنهم •

$$
\text { •-الاستغفار لهم والترحم عليهم • }
$$

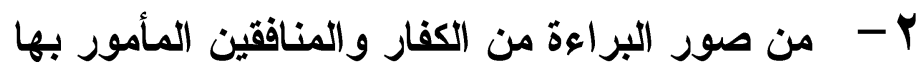

$$
\text { أ- ترك اتباع أهوائهم : }
$$

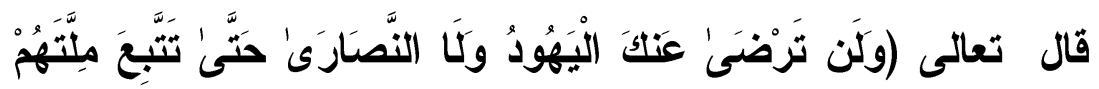

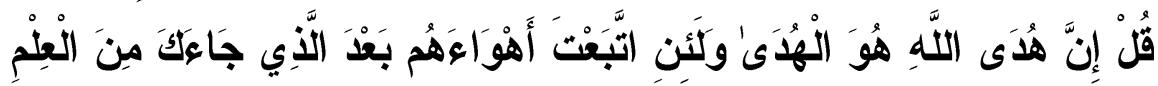

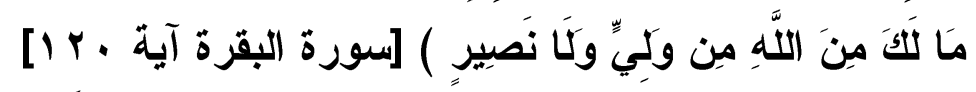

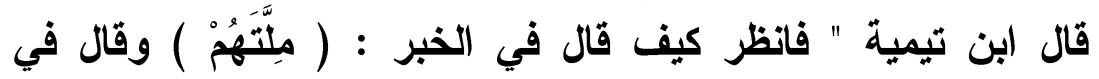
النهي : (أَهْوَاعَهُم ) لأنَ القوم لا يرضون إلا باتباع الملة مطلقا والزجر

$$
\text { وقع عن اتباع أهوائهم في قليل أو كثير "(1) معصيتهم فيما أمروا به : }
$$

يقال هنا: إن الله تعالى نهى عن طاعة الكافرين وأخبر أن المسلمين

إن أطاعوهم ردوهم عن الإيمان إلى الكفر والخسارة .

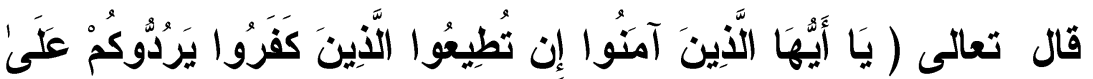

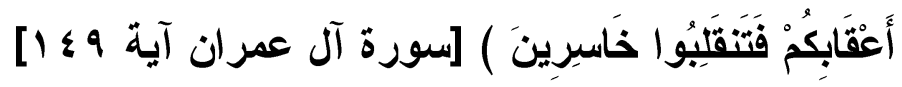

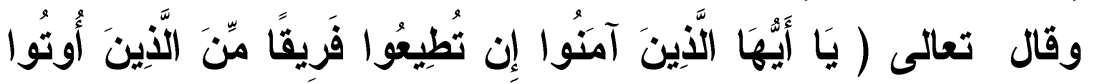

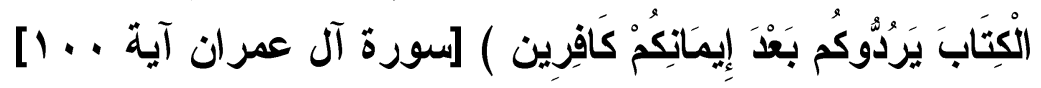

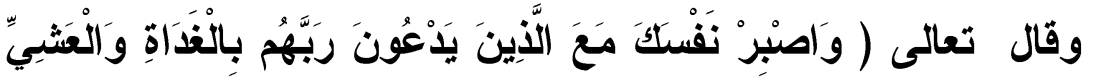

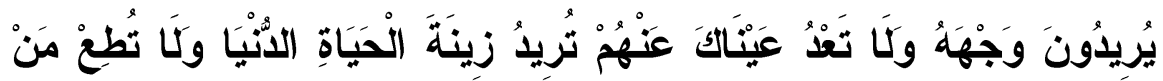

$$
\text { (1) مجموع القتاوى ج9 | صץ \&| }
$$




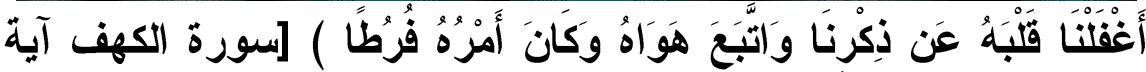

$$
\text { جـ- ترك الركون إلى الكفرة الظالمين : }
$$

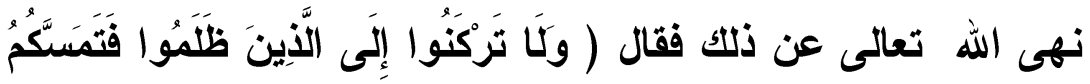

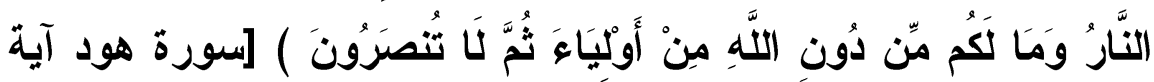

$$
\text { د- ترك مودة اعداء الله }
$$

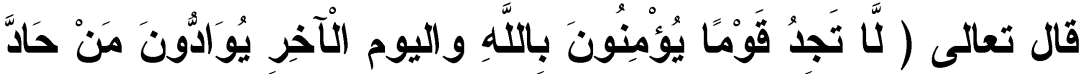

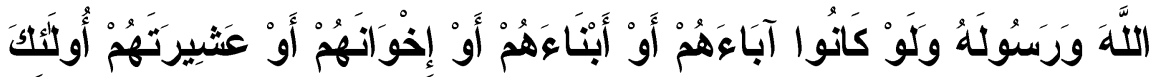

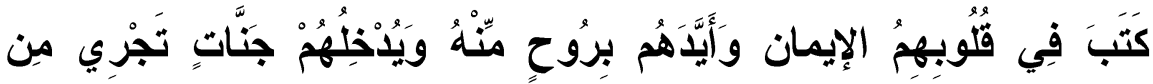

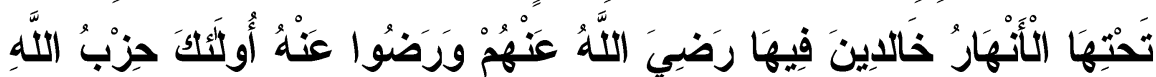

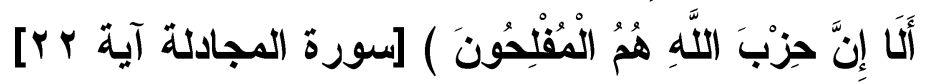

ويجب أن نؤكد هنا أن الله تعالى نفى الإيمان عمن واد أهله إذا لهاد

كانو ا مخالفين لله ورسوله فمن باب أولى نفي الإيمان عمن واد الكفار . هـ- ترك التثبه بالكفار في الأفعال الظاهرة هكذا يقول بلدي في

حديثّه

عن عبد الله بن عمر قال : قال رسول الله

مِنْهُمْ "(1)

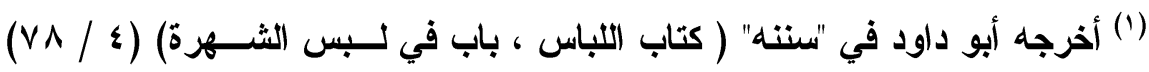

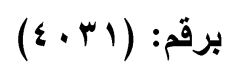


ويبدو موقف النصوص الثرعية من قضية الولاء والبراء أثهر من أن يعرف بها فهنايك صور شتى ومظاهر عديدة للنهي عن موالاة الكفار

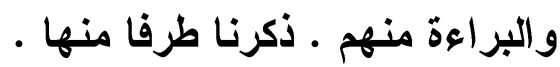
ويقفنا الفكر الإسدلامي في وهج الاحتدام والجدل فالطائفة الأولى من الآيات التي ذكرناها ظلت قضية الصوت الواحد فولاية الكفار توجب عدم الإيمان الأي رتب الخالق عليه غضبه وعذابه ، والخلود في الجحيم ، وهو لا يكون إلا للكافرين .

وإذا كانت الطائفة الأولى من الآيات القرآنية الكريمة استنفرت المسلمين وحذرتهم من موالاة الكافرين فمن أتى شيئا مما هم عليه فهو في عداد الكافرين

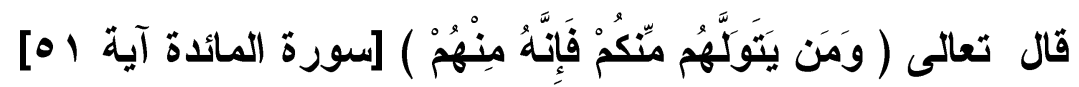

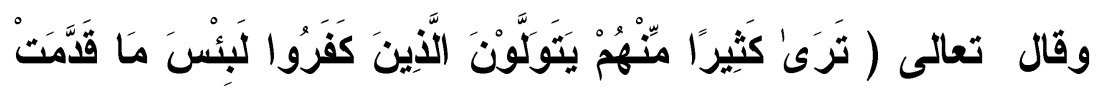

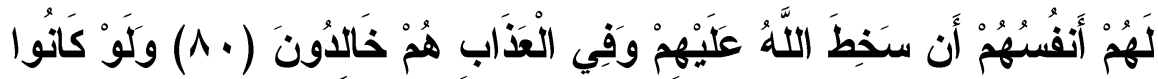

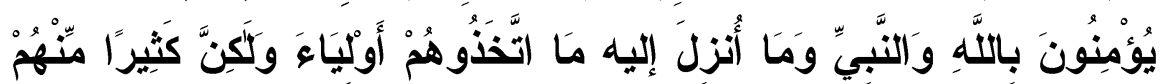

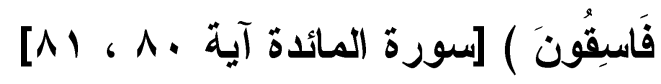

وفي الطائفة الثانية من النصوص الثرعية التي سنذكرها الآن نجدها تخرج عن مفهوم الطائفة الأولى إلى الاعوة إلى السلام مع الكفار ومعاملة غير المسلمين بالمعروف و ... الخ مما يجعل التعارض واضحا: ا-والآيات التي تدعو إلى السلام مع غير المسلمين إن جنحوا إليه، وتحث على عدم الاعتداء عليهم إلا إذا بدا منهم العدوان أو بدأوا به إله كثيرة نذكر منها . كيا 


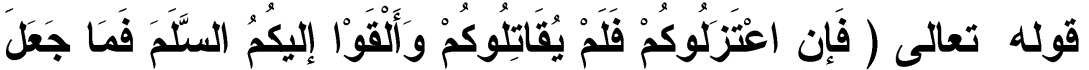

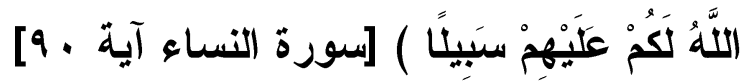

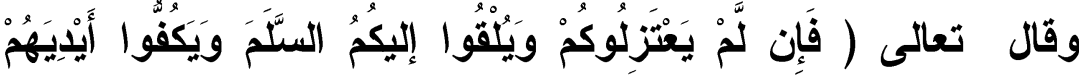

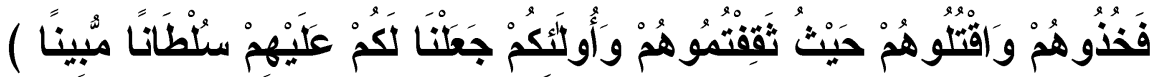

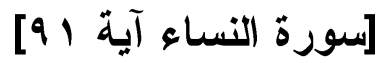

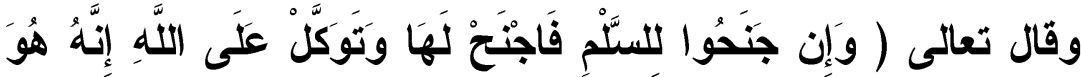

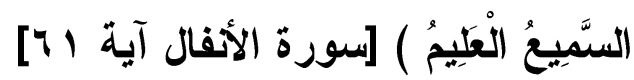

r-والآيات التي تدعو إلى معاملة غير المسلمين بالمعروف ،

شريطة عدم طاعتهم في دعوتهم إلى الكفر بالله أو الثرك كثيرة نذكر

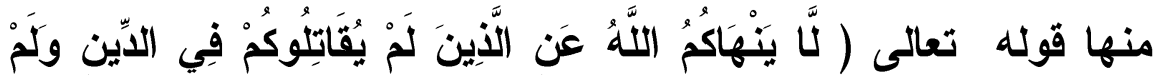

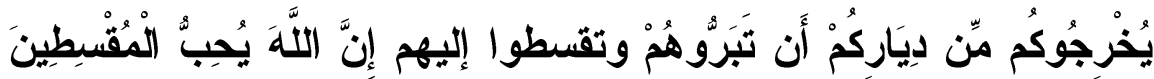

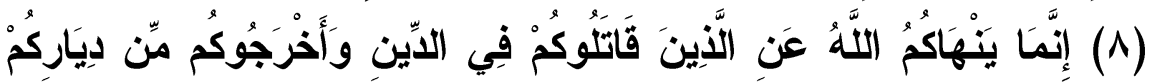

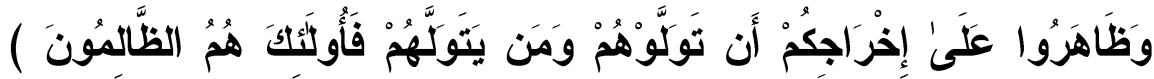

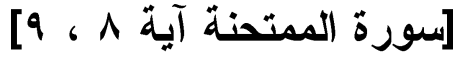

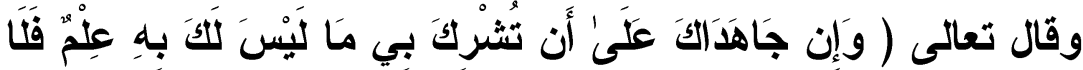

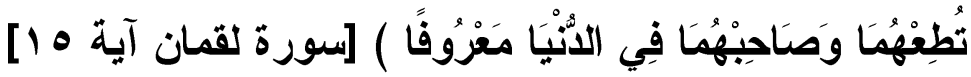

r-ويتبدى بوضوح الآيات التي تدعو إلى جوار غير المسلمين إذا

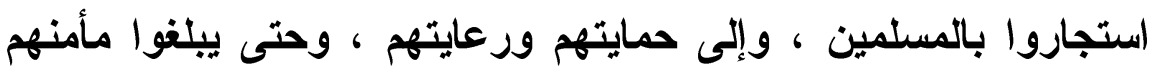

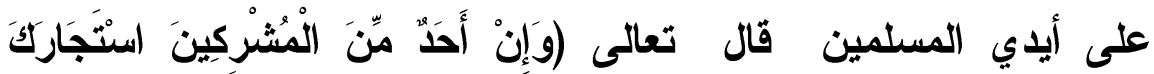

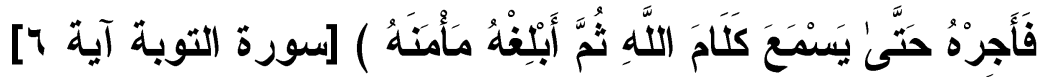
ع-ومعاملة غير المسلمين بالمعروف ننظر إليها من خلال السنة النبوية التي تجسد رفضها لكل إساعة لغير المسلمين . فالإسلام كفل لغير المسلمين في بلاد الإسلام حرية عقائدهم 


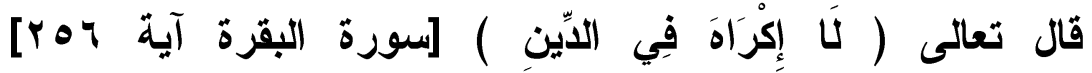

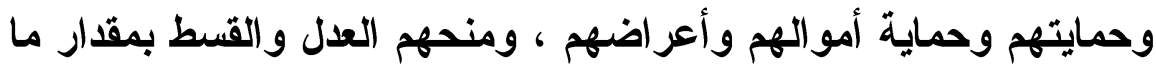

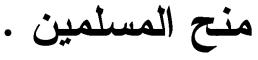
ويمكن أن نلاحظ أن " لهم ما لنا وعليهم ما علينا " فلماذا لا نركز على أحاديث النبي إنسانيته الفاضلة، وتعكس صورة الإسلام المشرقة ، التي تتفجر بقيم العطاء والحب وتواصل الممكن النبيل مع الآخرين ؟؟؟

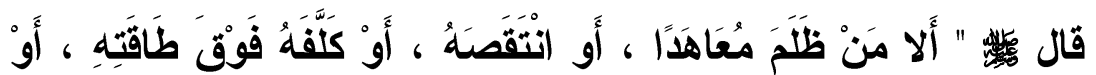

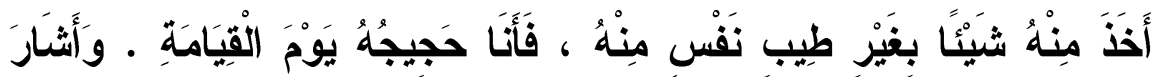

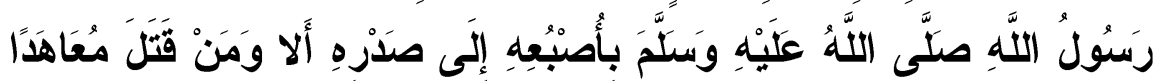

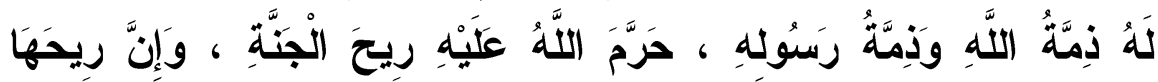

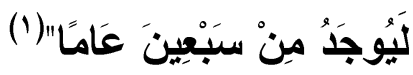

و البارز في عمل الصحابة رضوان الله عليهم أجمعين مع غير المسلمين أنه فكر إسلامي خالص يحيل الموضوع ليس إلى مجرد روئية خاصة للصحابة ، وإنما إلى نقطة انطلاق من سنته إلى إلى اللى الأمة الإسلامية عبر العصور قد يقال هنا: إن نماذج كثيرة من التزاث الإسلامي شواهد على الإحسان إلى غير المسلمين... ونحب أن نؤكد أننا سنذكر شيئا منها

(') أخرجه أبو داود في "سنته" ( كتاب الخراج و الفيء والإمارة ، باب في تعشير أهل

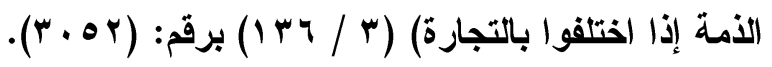


1-في خلافة أبي بكر - رضي الله عنه - كتب خالد بن الوليد رضي الله عنه في عقد الأمة لأهل الحيرة بالعراق - وكانوا من الن الهي النصارى- : " وجعلت لهم أيما شيخ ضعف عن العمل ، أو أصابته آفة فئ من الآقات أو كان غنيا فافتقر ، وصار أهل دينه يتصدقون عليه طرحت

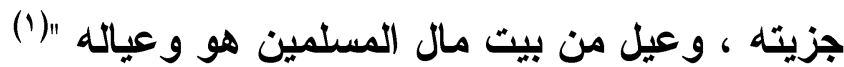
r-كان أبو بكر - رضي الله عنه - يوصي الجيوش الإسلامية

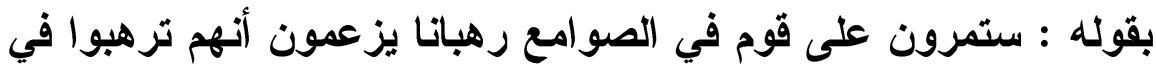

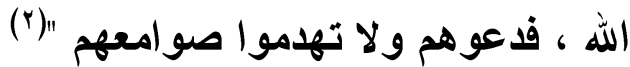
r-مر عمر بن الخطاب - رضي الله عنه - بباب قوم وعليه سائل يسأل : وكان شيخ كبير ضرير البصر ، فضرب عمر عضده من خلفه وقال : من أي أهل الكتاب أنت ؟ قال : يهودي ، قال : فما ألجأك إلى ما ها أرى ؟ قال : أسأل الجزية والحاجة والسن فأخذ عمر بيده وذهب به إلى الى منزله ... ثم أرسل إلى خازن بيت المال قال : انظر هذا وضرباءه فو الله

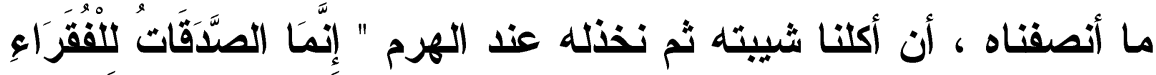
وَالْمَسَكاكِين " و الفقر اء هم المسلمون ، وهذا من المساكين من أهل الكتاب

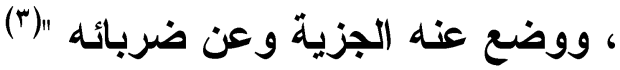
نحن هنا إذن مع طائفتين من النصوص الثرعية تمتلك الأولى الثي الروئة الواضحة التي تصرح بأن ولاية الكفار توجب عدم الإيمان الأي

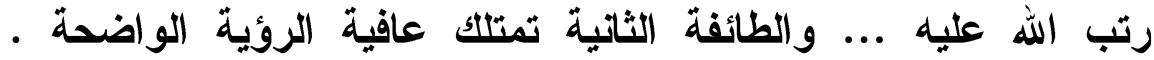

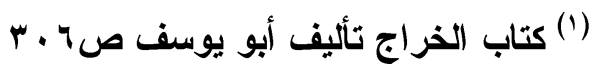

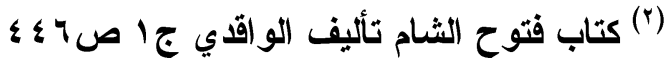

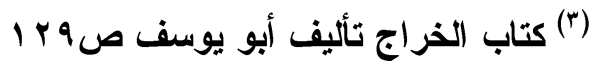


بالإحسان إلى غير المسلمين ، وتمتلك كذلك الكثير من الثواهد القولية

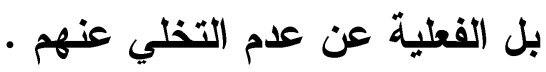

وقد يبدو التعارض واضحا عند العامة أو معاناتهم الصعبة في فهم

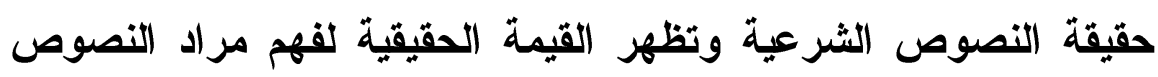

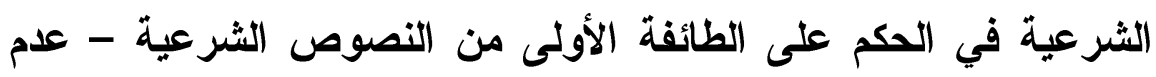

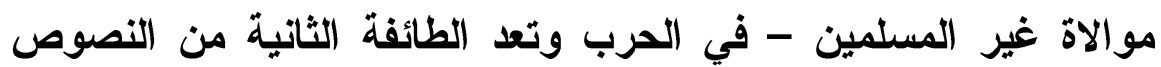

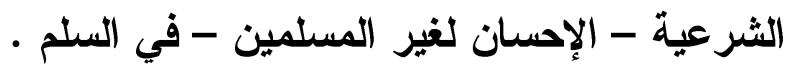
وليس هذا الحكم الذي أطلقته اندفاعا عاطفيا آزر به العيش في السلام ، وإنما هو حكم موضوعي ظاهرته نصوص شرعية كثيرة نذكر منها

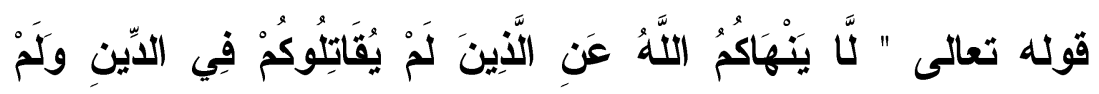

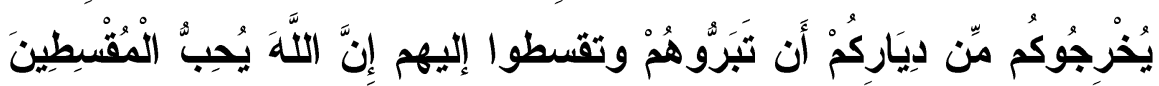

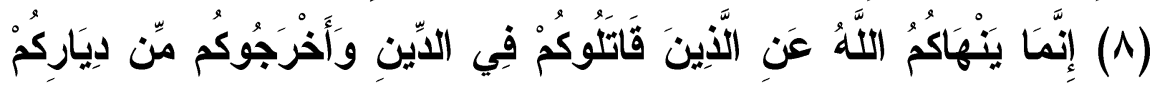

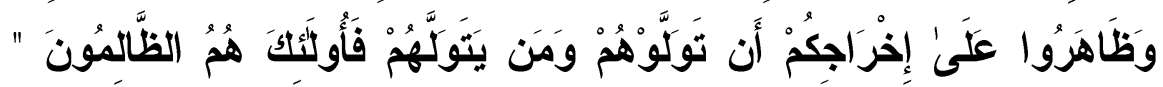

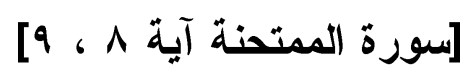

وهكذا تظهر القيمة الحقيقية التي تدل على أن الآيات المذكورة في

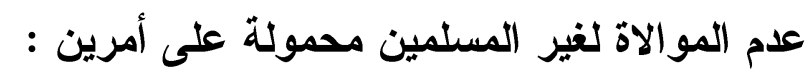
الأول : عدم المولاة لغير المسلمين في حالة الحرب

$$
\text { الثاني : علدم الولاء في الدين }
$$

وينبغي أن ننظر إلى الولاء : على أنه الحب على الإيمان

$$
\text { و البراء : الكره على الكفر }
$$


وينبغي أن ندرك ما يجب وفق مقصود الولاء والبراء وما لا يجب

ا-يجب عدم مواققتهم على دينهم فيما يخالف معلوما من الدين

بالضرورة .

$$
\text { r-يجب عدم محبتهم على كفرهم }
$$

ץ-يجب عدم إعاتتهم ونصرتهم على المسلمين بالنفس، أو السلاح،

$$
\text { أو المال أو...الخ }
$$

ويللنا الفكر الإسلامي على ما سبق أن ذكرناه وعلى حجم الدور الأي نهض به الإسلام في معاملة أهل الكتاب بل معاملة الآخر وهو دور ما كان يتاح للإنسانية إلا من خلال الإسلام وحسب الإسلام أن يكون دينا إنساتيا وأن يكون مدخلا إلى كيفية معاملة الآخر على مر العصور • والثواهد أكثر من أن تحصى ونذكر منها :

1-أباح الإسلام زواج الكتابية ومعلوم ما بين الزوجين من مودة

r-أباح الإسدلام ذبائح أهل الكتاب وطعامهم قال تعالى (اليوم أُحلَّلَ لَكُم

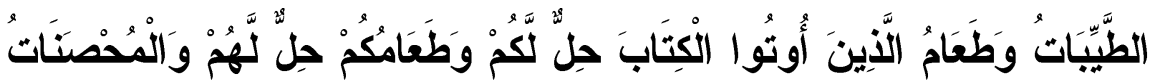

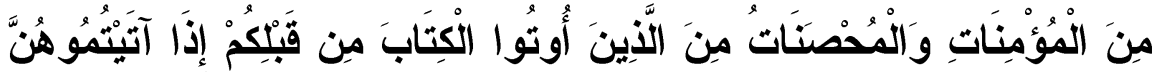

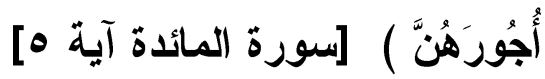

r-عقد النبي رسول الله 
جذهم وعالمهم عبد الله بن سلام فذخل في الإسلام وأبى عامتهم إلا

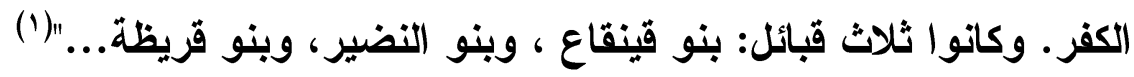

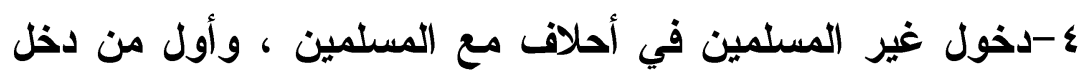

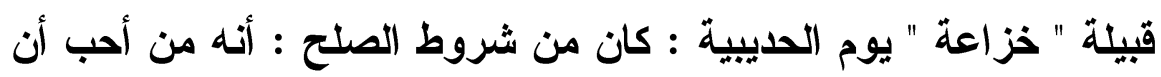

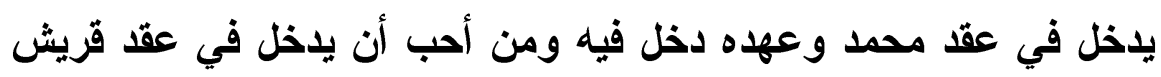

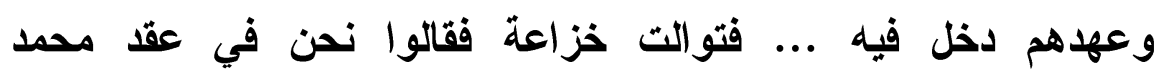

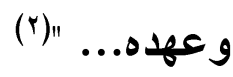

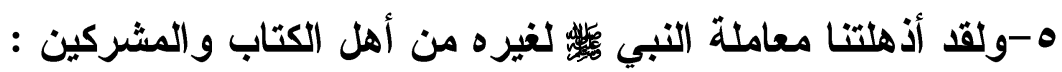
كان

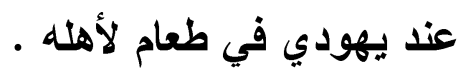

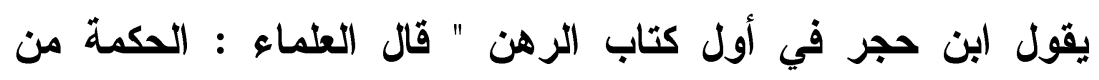

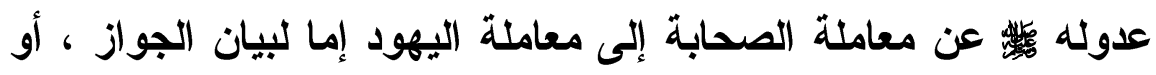

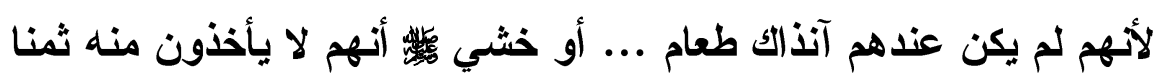

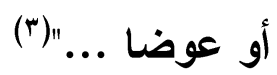

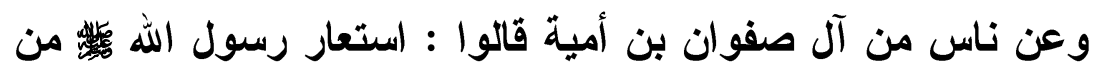

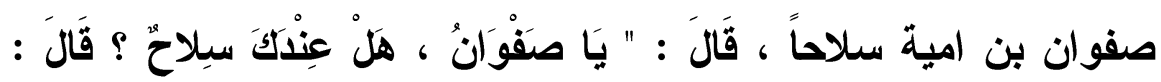

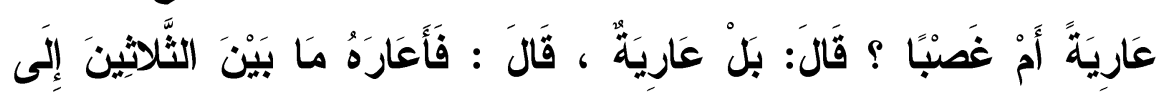

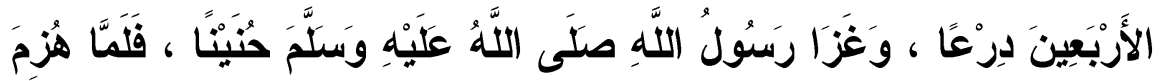

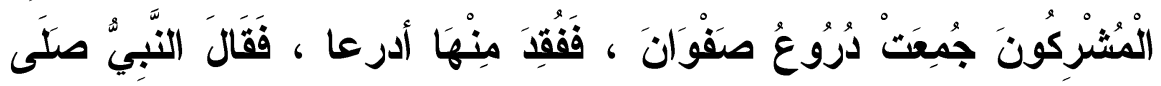

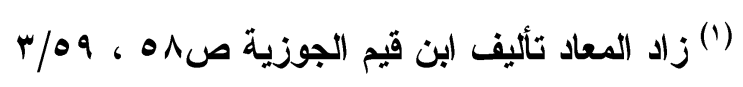

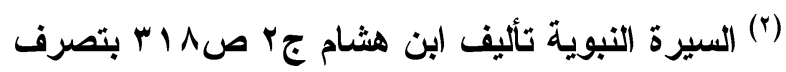
(") 


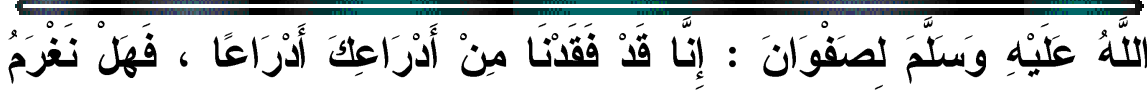

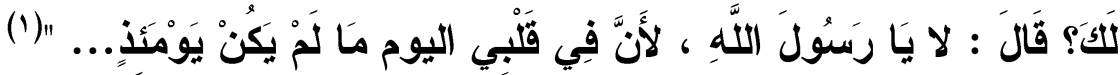
وكاتت العرب تنعت للرسول - رضي الله عنه - أن يتداوى عند " الحارث بن كلاة الثقفي • وهو

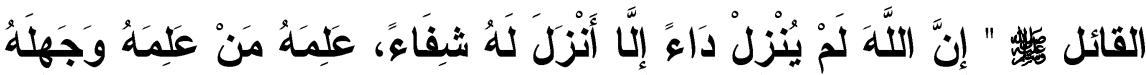

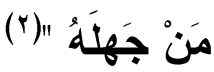

ولهذا الفهم ينبغي أن تتوجه العقول لتعلم أن المقصود من الولاء

المنهي عنه والبراء المأمور به هو :

$$
\text { Y-ألب على الكفر الكره على الإيمان }
$$

ولا يفوتنا أن نؤكد أن الولاء والبراء فيما يتعلق بجانب الدين ـ أما

غيره من المنافع والمصالح الانيوية المشتركة بين المسلمين وغيرهم فلا حرج ، وأن ما ورد في معاداة غير المسلمين فهو محمول على حالة الحرب دون غيرها ، وأكثر من ذلتك قد تحب غير المسلم بعقلك لخصلة خير فيه .

(1) الحاكم في "مستدركه" ( كتاب البيوع باب لا يجوز لامرأة أمر في مالها إذا ملــــ

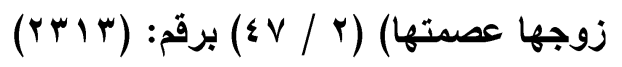

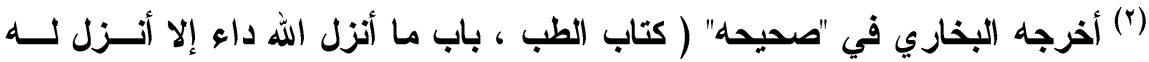

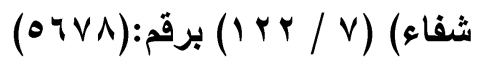


مجلة كلية الذراساتات الرإلإمية والعريبة بنات بنهي لسويفـالعذد العاشر

قال ابن الوزير" يصح أن يحب المسلم غير المسلم لخصلة خير هي

فيه ، لا كفره"(1)

(') اثار الحق على الخلق تأليف ابن الوزير ص. PV 


\section{الشورى في الإسلام}

نتوجه إلى النصوص الثرعية لنؤكد أولا النهي عن الخروج على

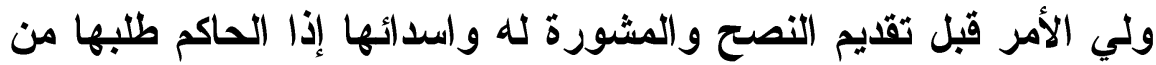

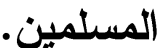

من السهل إذن أن نذكر النصوص الثرعية الدالة على وجوب طاعة

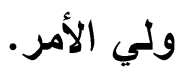

عن عبادة بن الصامت - رضي الله عنه - قال : " بَايَعْنَا رَسُولَ اللَّهِ

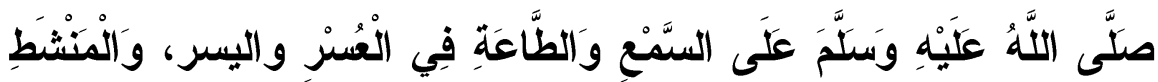

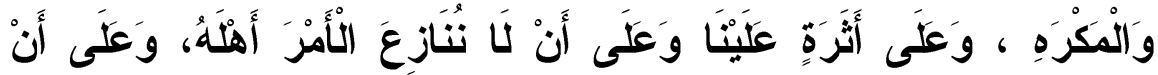

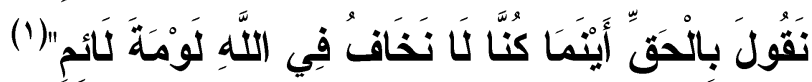

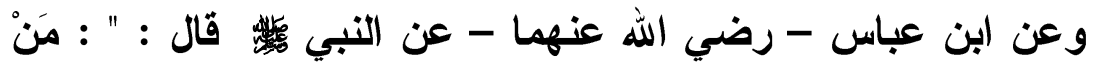

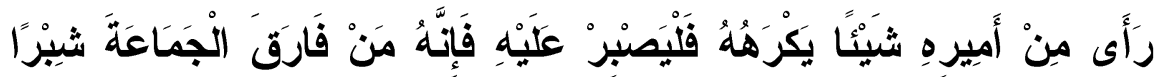

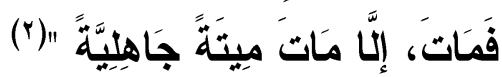

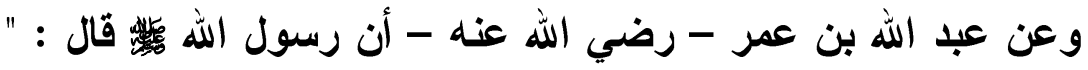

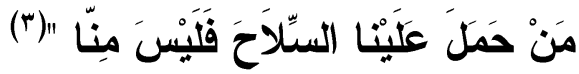

(1) أخرجه البخاري في "صحيحه" ( كتاب الفتن ، باب قول النبي سترون بعدي أمورا

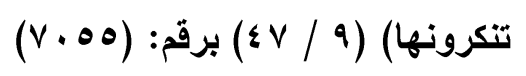

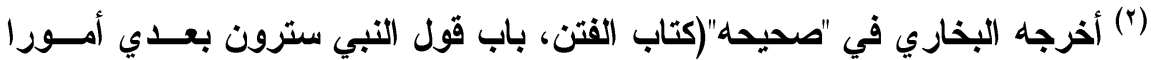

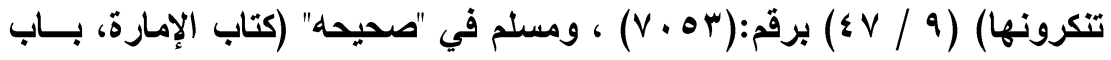

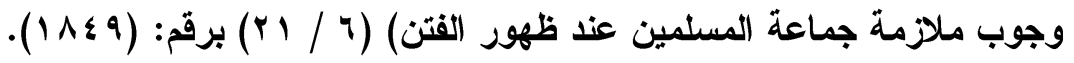

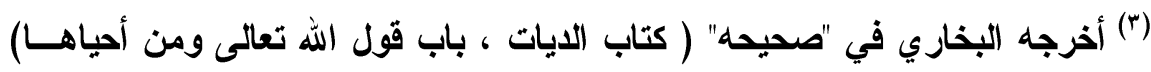

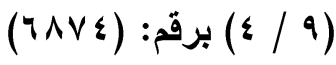


عن أم سلمة - رضي الله عنها - زوج النبي

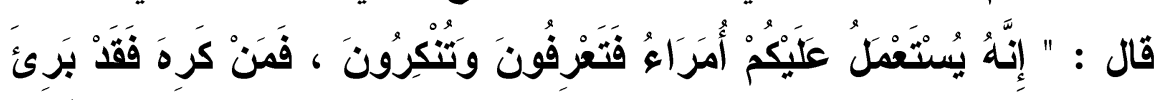

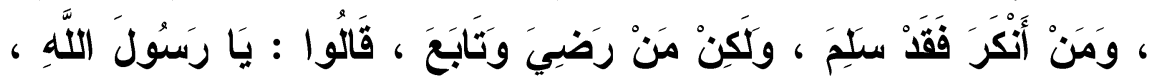

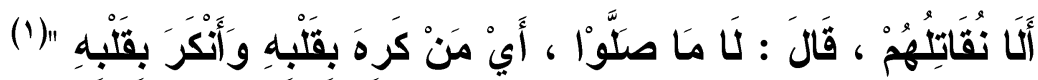
وعن عوف بن مالك - رضي الله عنه - عن رسول الله

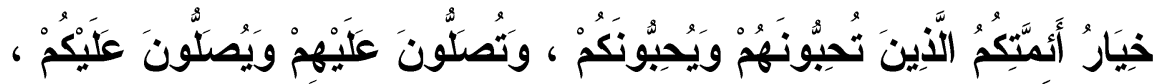

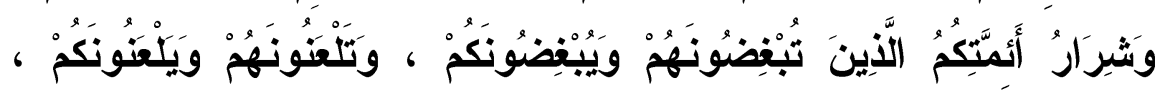

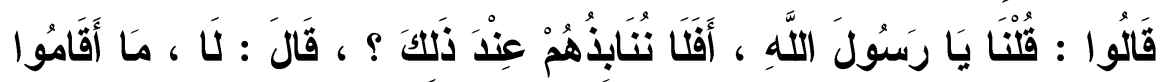

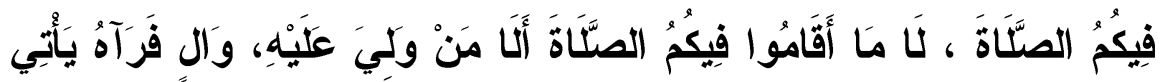

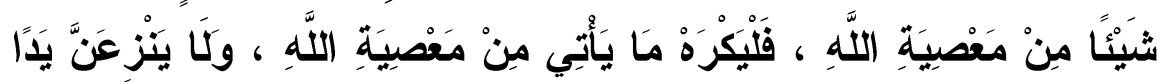

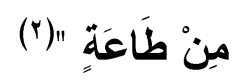

وعن ابن عمر - رضي الله عنهما - قال : سمعت رسول الله

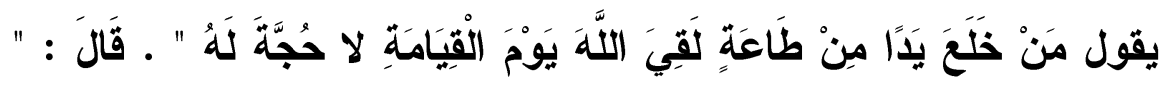

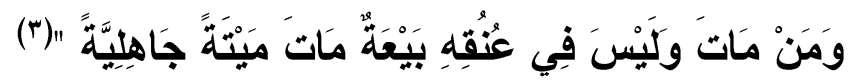

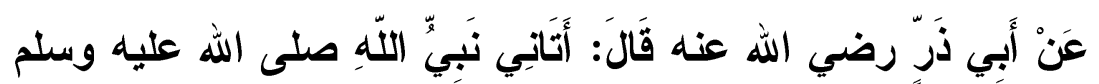

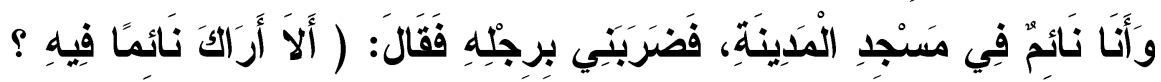

(1) أخرجه مسلم في "صحيحه" ( كتاب الإمارة ، باب وجوب الإكار على الأمراء فيما

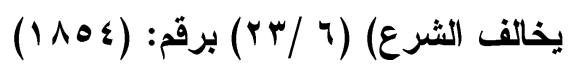

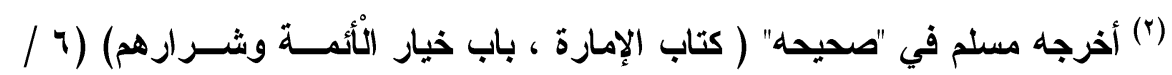

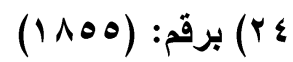

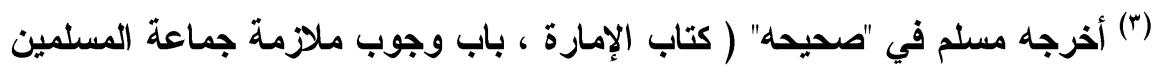

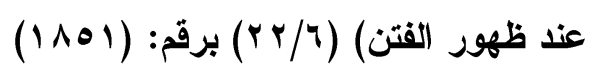




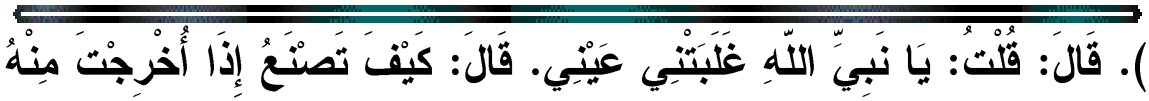

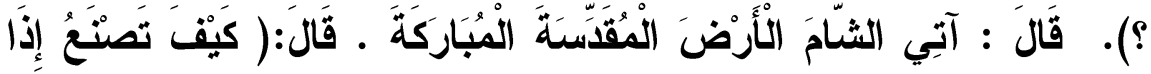

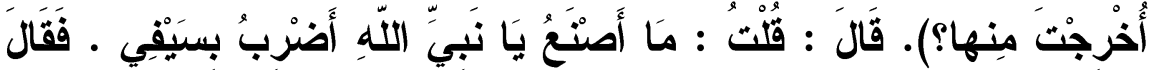

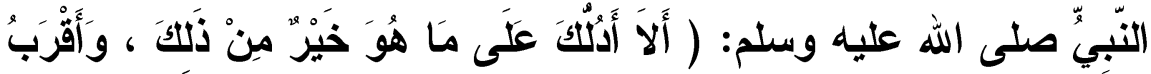

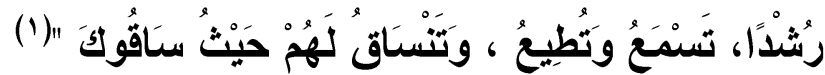
والواقع أنتا لا نعاني طويلا لنفهم أن طاعة ولي الأمر من باطن طاعة الله و الرسول.

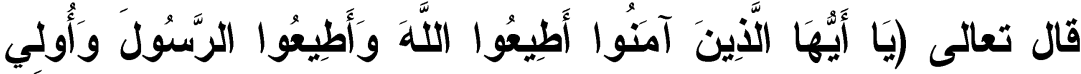

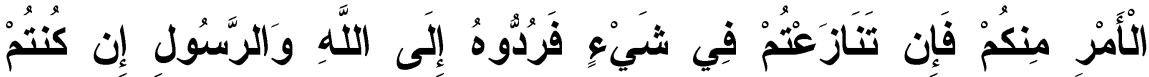

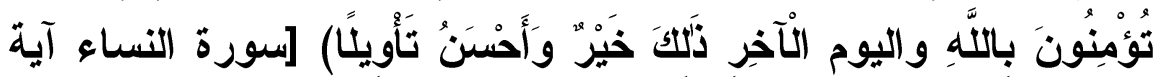

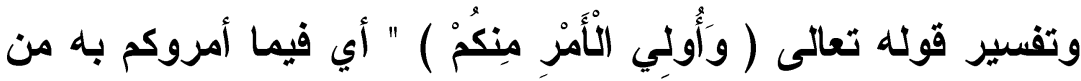

طاعة الله لا في معصية الله ، فإنها لا طاعة لمخلوق في معصبية الله "(؟) وقال الإمام القرطبي ( وَأولي الْأْمَ مِنمُ ) " أهل القرآن والعلم ، وهو اختيار مالكك رحمه الله ونحوه قول الضحالك قال : يعني الفقهاء

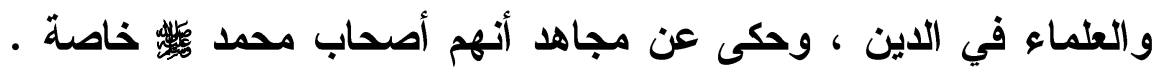
وحي عن عكرمة أنها إثارة إلى أبي بكر وعمر - رضي الله عنهما -

(1) أخرجه ابن حبان في "صحيحه" ( كتاب التاريخ ، ذكر الإخبار عن إخراج التــاس

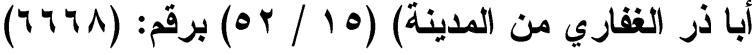

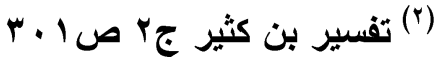


خاصة ... قلت وأصح هذه الأقوال الأول والثاني ؛ أما الأول فلأن أصل

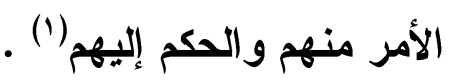
هل نستطيع أن نقرأ هذه القضية - الثورى في الإسلام - قراعة

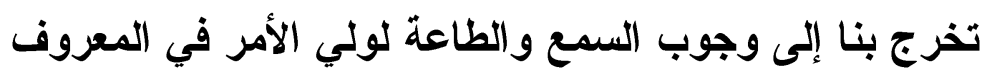

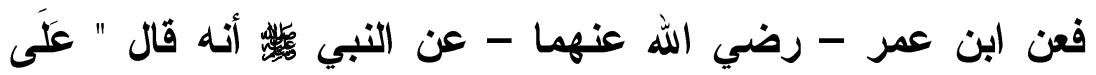

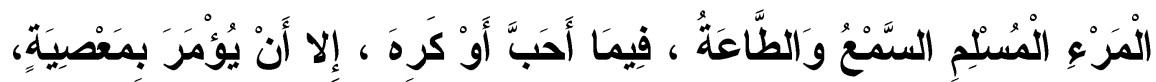

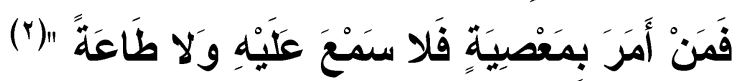
فإذا أدرنا الحديث على قضية الثورى في الإسلام فسنجد قوله

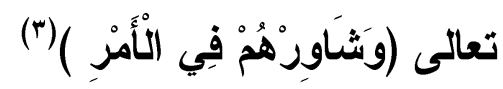

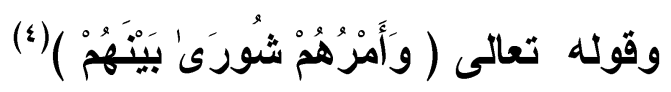

وبدهي أن الثورى فيما لم يرد نص صريح فيه من الكتاب أو السنة

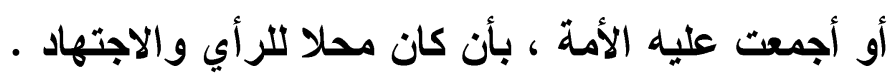

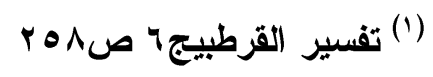

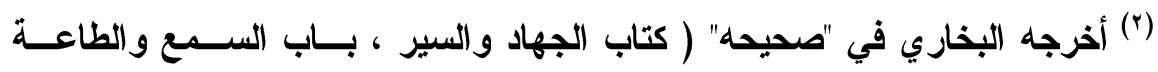

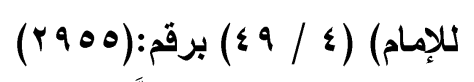

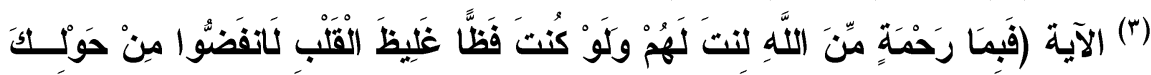

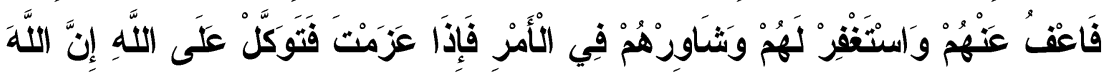

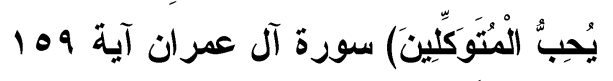

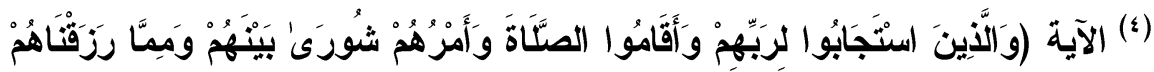

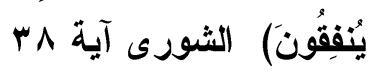


ونفهم من هذا أن ما ورد فيه نص أو إجماع ، فلا يجوز للحاكم أن

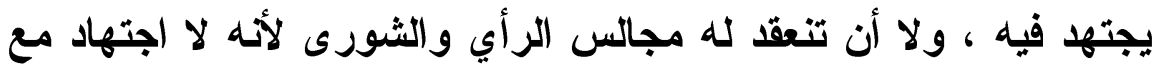
وجود النص ، وما أجمعت عليه الأمة .

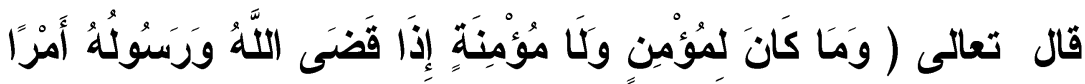

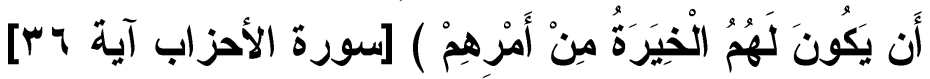

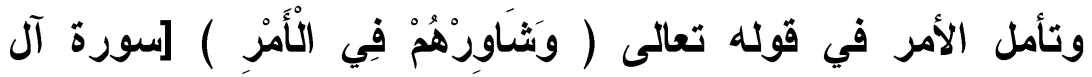

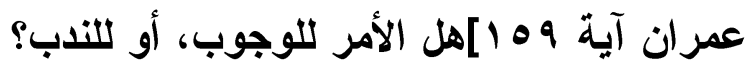
اختلف العلماء ـ قال القرطبي " واختلف أهل التأويل في المعنى الذي

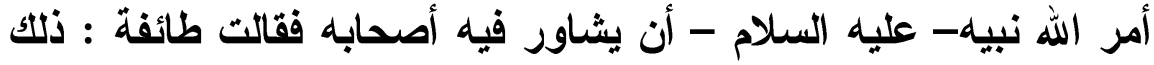
في مكان الحروب ، وعند لقاء العدو ... وقال آخرون : ذلك فيما لم يأته

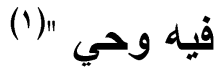
وقال ابن الجوزي " وفي الذي أمر بمثاورتهم فيه قولان : حكاهما

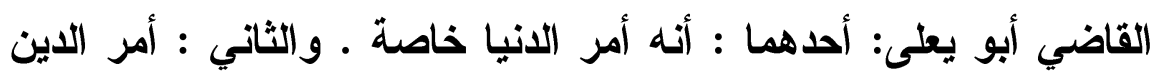

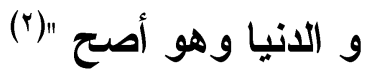
وأما كون الثورى ملزمة للحاكم أو غير ملزمة فهذا مما اختلف

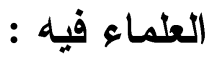

ولعلنا لا نخطئ إذا قلنا إن ترك التثاور معناه الايكتاتورية التي تعرض مصالح المسلمين للخطر أو الفوات ـ لكن ليس كل ما نريد الإقدام

$$
\begin{aligned}
& \text { (1) تفسير القرطبي ج\& ص • §؟ }
\end{aligned}
$$

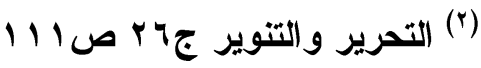


عليه يحتاج إلى تثاور. ولكن تطلب المشورة عند الإثكال أو الأمور

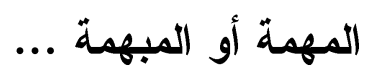

و إذا كان هناك من يرى أن المشورة واجبة ، وهناك من يرى أنها مستحبة وكل فريق من الفرقاء يسوق الأدلة والحجج ويمكننا من خلا وله

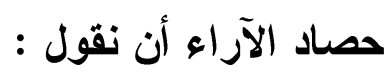

يمكنا تقسيم الثورى من حيث الوجوب و الندب إلى : 1-شورى واجبة ونتيجتها ملزمة في الأمور الدينية

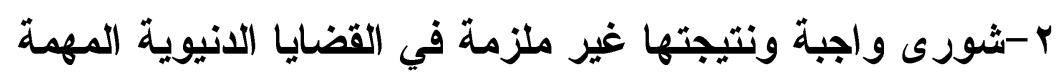

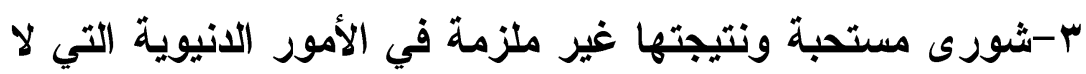
نعاني فيها طويلا لنفهمها .

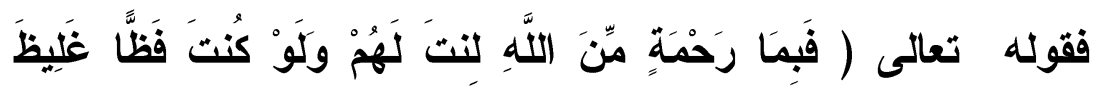

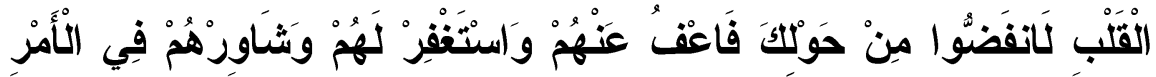

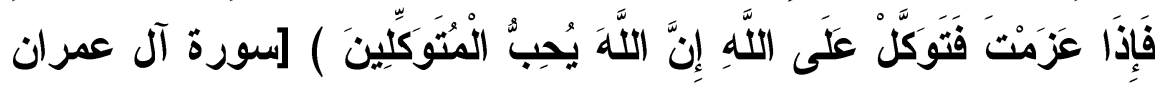

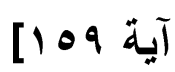
ونستطيع أن نقول : إن العفو والاستففار لمن أخطأوا في غزوة أحد هو تفضل منه

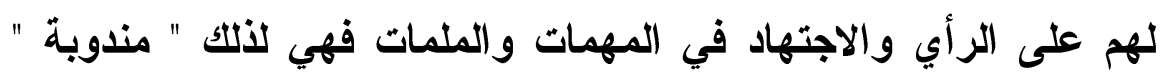

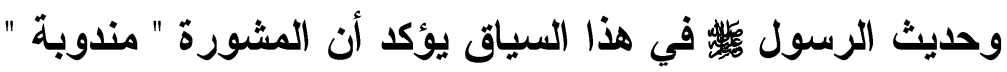


عن عياض بن غنم - رضي الله عنه - قال : قال الرسول

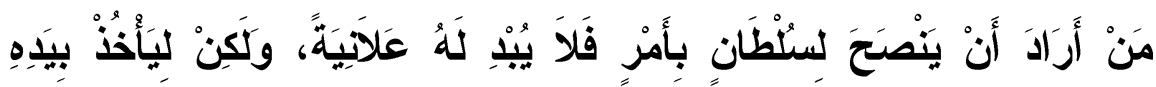

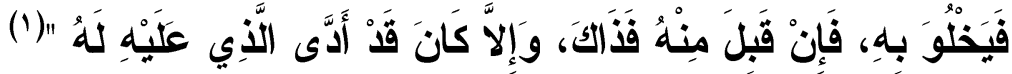
ولكن لم يقل أحد بأته المو اظبة عليه تأكيدا لأهمية . لعاله

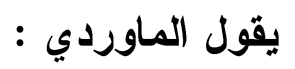

اختلف أهل التأويل في أمره ت تعالى لنبيه به من التوفيق ، وأعانه من التأييا على أربعة أوجه : أحدها: أنه أمره بمشاورتهم في الحرب ليستقر له الرأي الصحيح

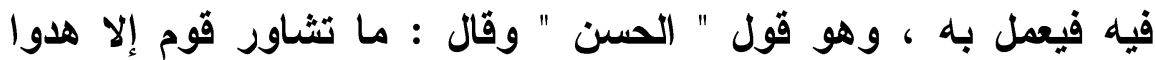

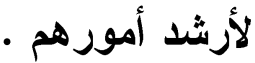

الثاني: أنه أمره بمشاورتهم تأليفا لهم ، وتطييبا لنفوسهم ، وهذا

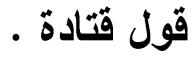

الثالث: أنه أمره بمشاورتهم لما علم فيها من الفضل ، وما عاد بها

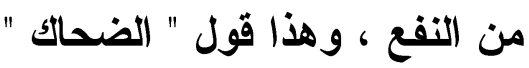
الرابع : أنه أمره بمشاورتهم ليستن به المسلمون ، ويتبعه فيها

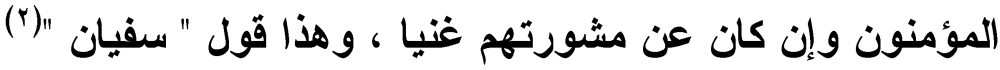

(1) أخرجه الحاكم في "مستدركه" ( كتاب معرفة الصحابة رضي الله تعالى عنهم ، من

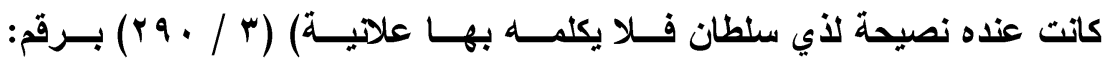

$$
\text { (Or. O) }
$$

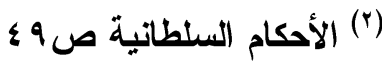


ويبدو موقف العلماء من قضية حكم الحاكم يرفع الاختلاف من

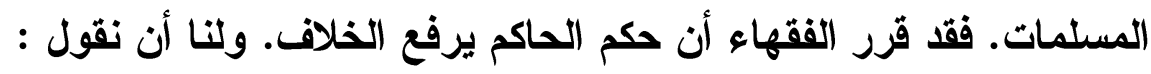

في هذا الحكم قضية فكرية تستحق مزيدا من التأمل لأن الحاكم لم

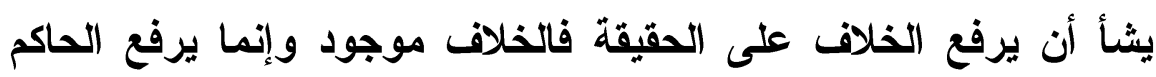
بعض آثاره حتى يبدو كالمسألة التي لا خلاف فيها .

يتبدى في هذا الكلام - و إنما يرفع بعض آثاره - قضية فكرية آخري

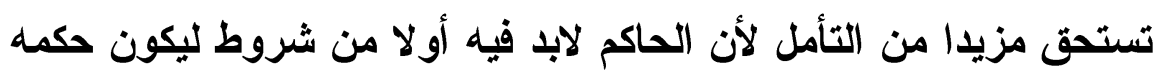

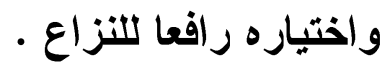

"الاول : أن يكون النزاع سائفا والخلاف معتبرا

الثاني : أن يكون اختياره لهذا الرأي مبنياً على مصلحة عامة لهون

الثالث : أن تكون المسألة من وسائل الولاية المختصة بالحكم "(1) ومن آثار الخلاف التي يرفعها حكم الحاكم واختياره لأحد المسائل

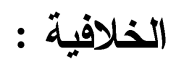

1-في القضايا التي يتم رفعها للحاكم أو القاضي ، فإن حكمه يرفع

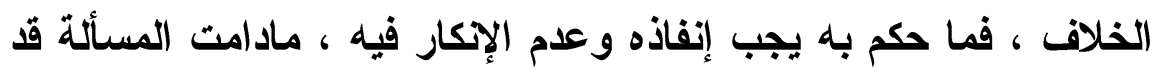

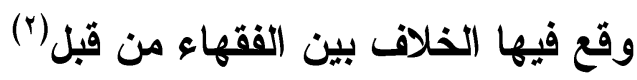

(') حم الحاكم يرفع الخلاف تأليف الأستاذ الدكتور عبد السلام بن محمـــ السـويمر VV ص

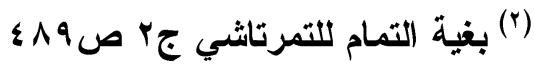


ونستطيع قراعة البعد الآخر في هذه القضية - أن نزعم أن العبرة

هنا بمذهب الحاكم " وهذا ما قعده الفقهاء وقرروه "(1) r-في حال اختيار الحاكم لأحد الرأيين الفقهيين السائغين فقها وإلزام القضاة بالحكم به ، فلا يسوغ هنا الخلاف من القضاة في هذه (ץ)" (المسائل ويتبدى بوضوح أن الإلزام يكون بأحد الآراء الفقهية في القضاء ويكون للفقهاء نزاع في جوازه ـ r-في الأعمال المناطة بولي الأمر من عموميات المسائل ؛ كمسائل السياسة الشرعية ، تجريما وتقديرا للعقوبة في التعازير وغيرها ـ وكذا

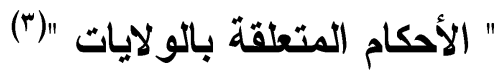
وقد سئل ابن تيمية عمن ولي أمر من أمور المسلمين ومذهبه لا يجوز شركة الأبدان. فهل يجوز له منع الناس ؟ أجاب " شركة الأبدان التي تنازع الفقهاء فيها نوعان :

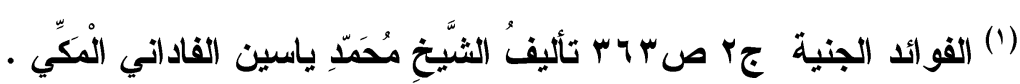

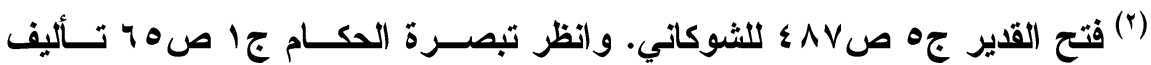

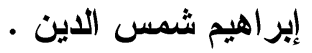

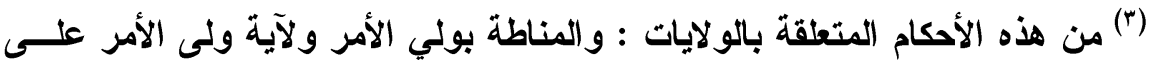

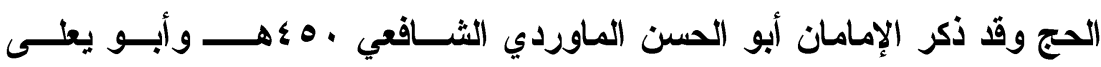

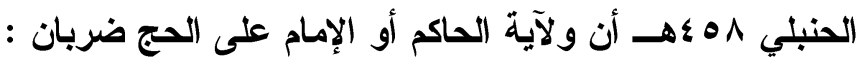

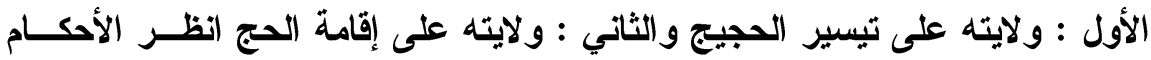

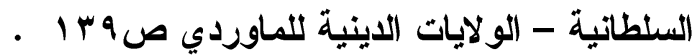


أحدهما : أن يشتركا فيما يتقبلان من العمل في ذمتها كأهل

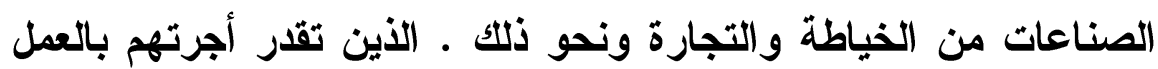

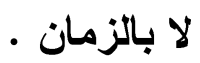
فهؤلاء جوز الفقهاء اشتراكهم كأبي حنيفة ومالكك وأحمد الثاني : شركة عقود وهو أن يثتري أحد الثريكين بجاهه ولثريكه

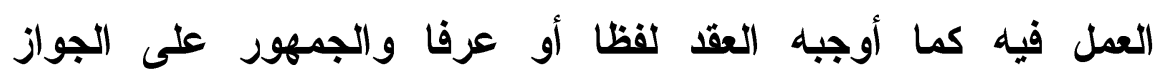

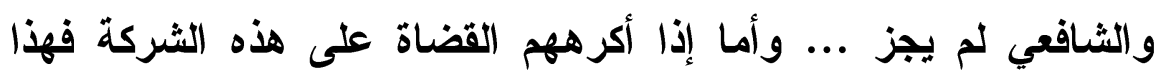
ليس من باب الإكراه على العقود بغير حق ؛ لأن القضاة هم الذين يأذنون

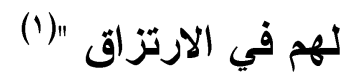
ومن هنا فإن الواجب على ولي الأمر تنفيذ ما اتفقت عليه كلمة

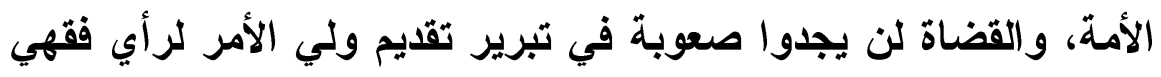

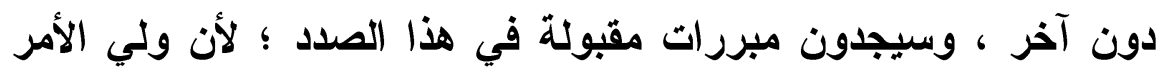

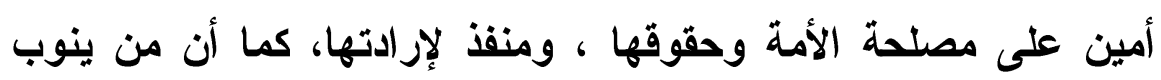

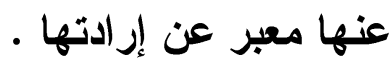

وينبغي على الحاكم أن يبذل جهذه واجتهاده في معرفة الخير

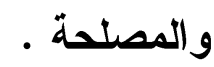

ولسنا نرى في هذا الاجتهاد ما يمكن أن يجر الحاكم إلى الحكم

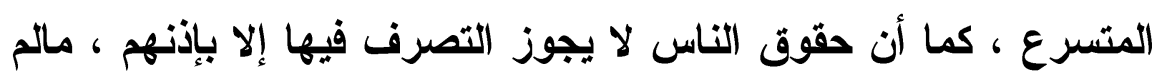

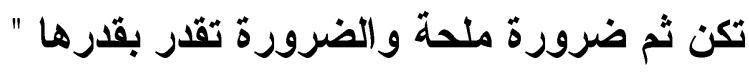

(') مجموع فتاوى ابن تيمية مسألة الجزء الثلاثون باب الثركة ص V. 
وحديث الرسول ئس الأي أمامنا يثير هذه القضية المهمة - عدم

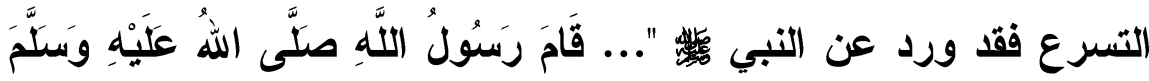

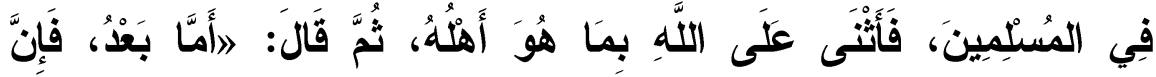

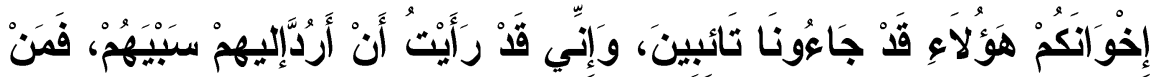

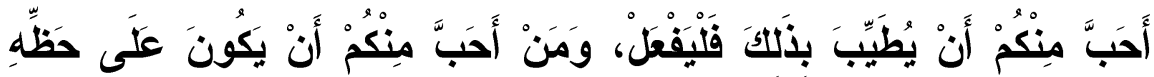

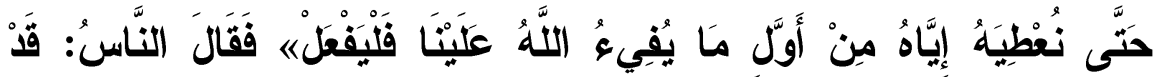

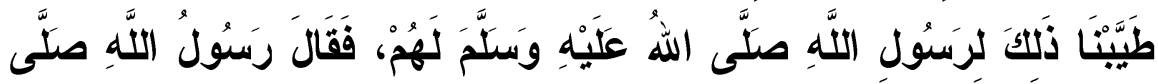

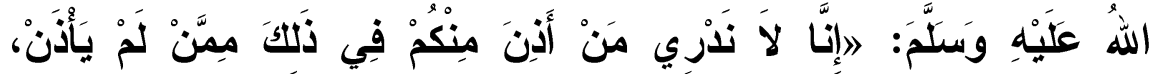

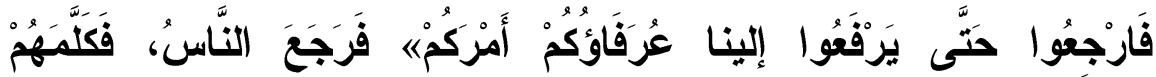

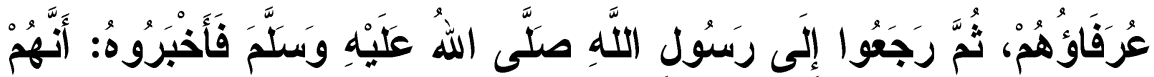

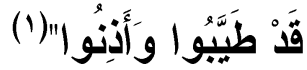

ونستطيع في مجال إخضاع اجتهاد الحاكم للنصوص الثرعية وفي

توفيقه أحيانا كثيرة صورة لعدم توفيقه فقد فجرت هذه المقابلة بين عمر أن - رضي الله عنه - وامرأة بيان التحليل والتحريم " حين أراد عمر رضي الله عنه - تحديد المهور ، ولكنه رجع عن اجتهاده حينما ذكرته

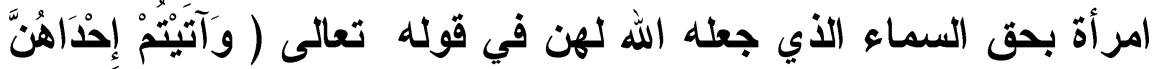

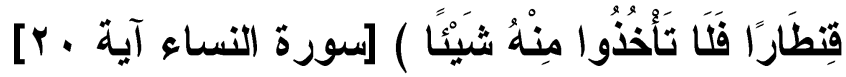

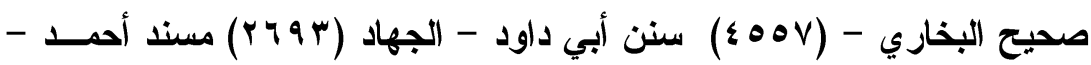

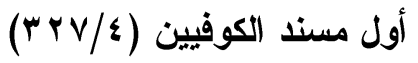


ومن الحق أن نقول : لقد كان عمر- رضي الله عنه - يرى في

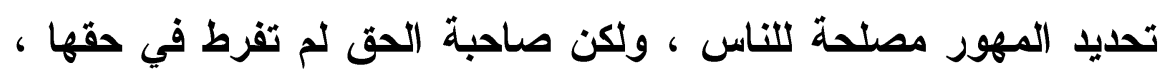

ولم تأذن للحاكم أن يتصرف فيه دون إذنها .

ومهما يكن من شيء فإن دعوة حقوق الناس ، والحجر عليهم فيما

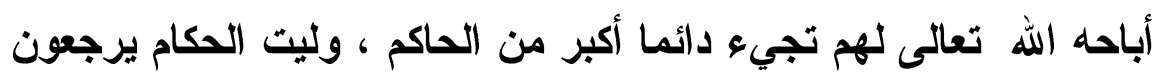

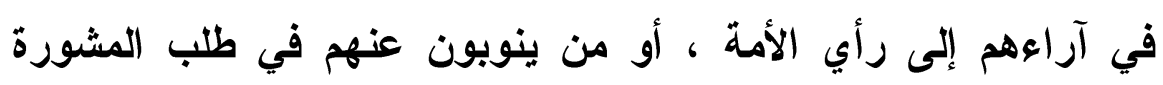

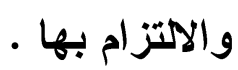

وبدهي أننا كما ندافع عن حقوق الناس وعدم الحجر عليهم فيما

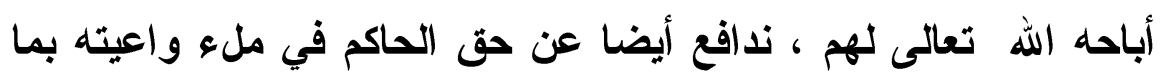

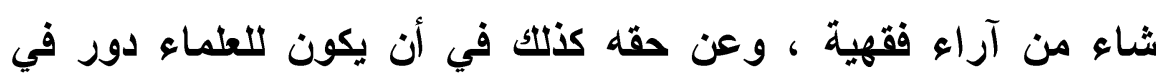
نصحه وإرشاده لأن :

\section{الدين النصيمة}

لنكن على وعي بحديث الرسول: الندالذي فصل القول في هذه القضية

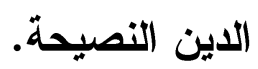

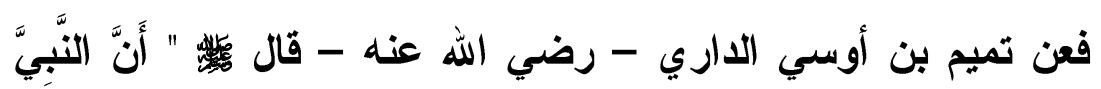

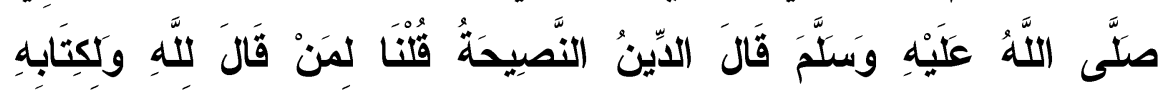

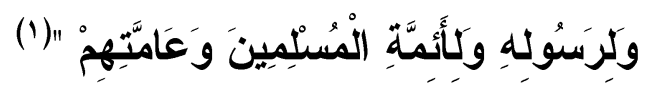

(1) أخرجه البخاري في "صحيحه"( كتاب الإيمان ، باب قول النبي صـلى الله عليـهـ

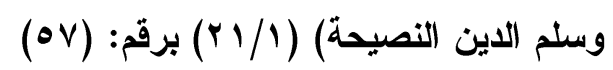


وللعلماء آراء جهيرة في النصح لأئمة المسلمين " قال النووي -

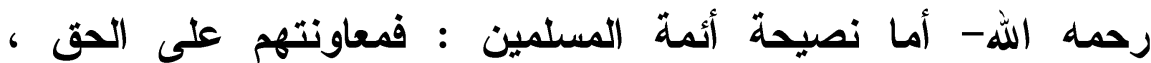
وطاعتهم فيه وأمرهم به ، وتتبيههم وتذكيرهم برفق ولطف ، وإعلامهم

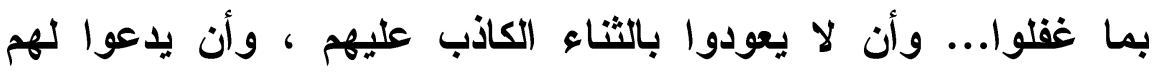

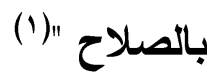

وقال ابن رجب رحمه الله: " النصيحة لأئمة المسلمين: معاونتهم على الحق وطاعتهم فيه وتذكيرهم به، وتنبيههم في رفق ولطف،

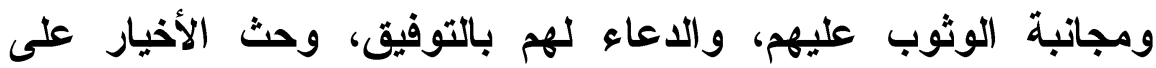

كذلك يمكن أن نلاحظ - ليس على هذا الحديث وحده - ولكن على بقية الأحاديث التي سنذكرها في هذا الموضوع - الاين النصيحة - أن الن الني

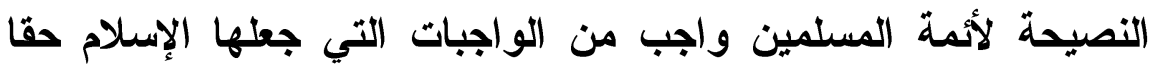

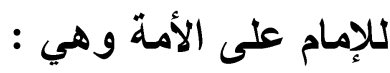

1-الطاعة للحاكم في غير معصية .

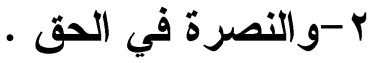

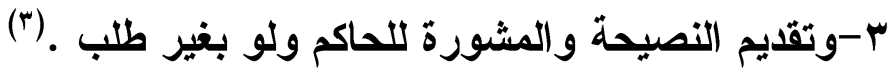

واذا خلا كلام أهل الحل والعقد أو علماء الأمة من تقديم النصيحة للحاكم أو ولي الامر. أو التقصير في واجب النصيحة كان إثم هؤلاء

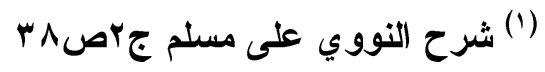

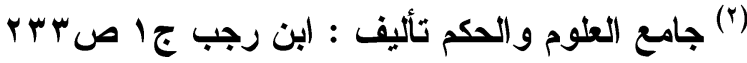

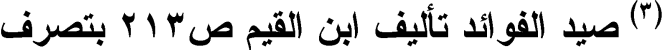


عظيما سواء أكانت النصيحة متعلقة بشخص الحاكم ، أم بواجبه نحو أمته ؛ لأن ذلك يعد من باب الغش والخيانة له والتفريط في حق من

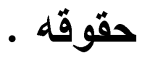

ويمكن النظر إلى نفس هذا الكلام من جهة أن تقصير الحاكم في تقبل النصيحة أو تقصيره في النصح لأمته غش لها وخيانة تحول بينه وبين رحمة الله وجنته ، ويستوجب بها عقاب الله تعالى • وتصف الأحاديث النبوية العلاقة بين الحاكم وأمته .

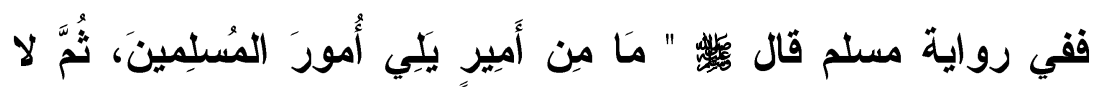

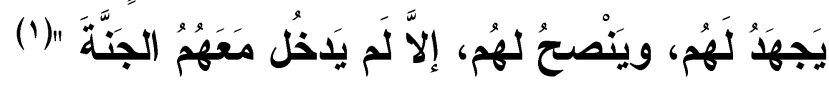

وفي حديث أبي يعلى "معقل بن يسار" قال : سمعت رسول الله

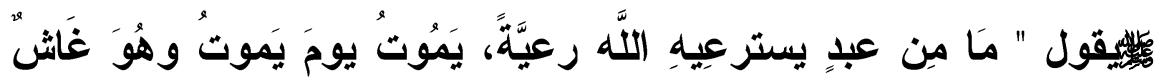

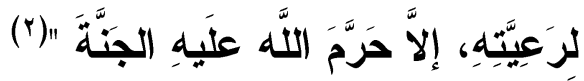
وفي حديث أبي مريم الأزدي - رضي الله عنه - قال سمعت رسول

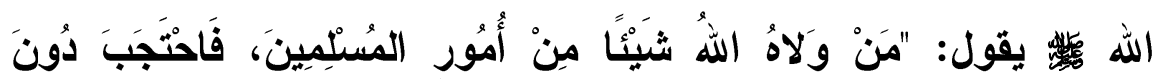

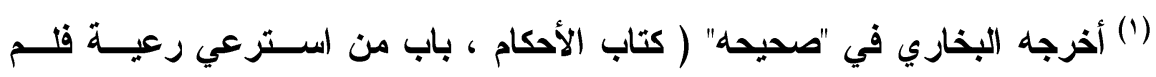

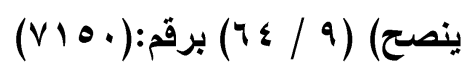

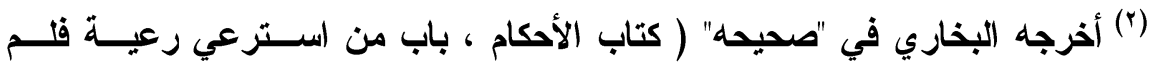

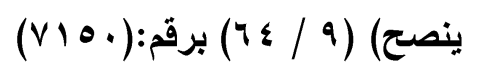




\section{فتنة تكفير المصلمين بين التطرفه والإعتكال}

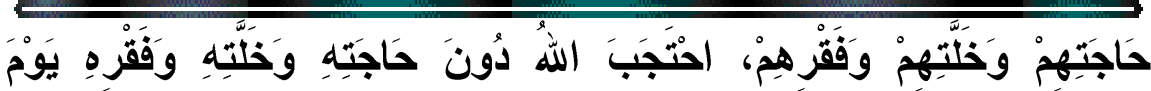

(1)" الْقِيَامَةِة

ولكنتا لا نستطيع هنا تجاوز كيفية النصح للحكام وبخاصة عند المأخذ التي يمكن أن يلاحظها العلماء عليهم ـ فقد يؤدي الإغلاظ لهم في القول أو التشهير بهم إلى إثارة نفوسهم وهم يملكون الأمر وتوجيهاتهم ناقذة مما يعود بالضرر على من يسدي النصح إليهم. وهو مأخذ صوابي يضعه الناصح في حسابه وهو يسدي النصيحة. ولقد أعطى لنا القرآن الكريم ما ينبغي أن نتأى عنه في الحديث مع الحاكم وما ينبغي أن نفعله

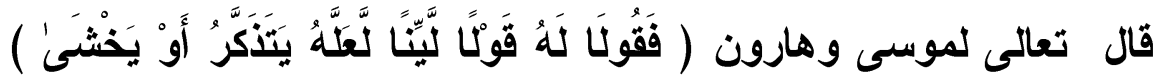

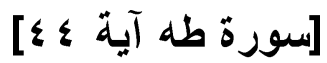
ونستطيع - في مجال تقديم النصح للحاكم - أن نسقط كل هذه المأخذ على الحسن البصري - رحمه الله - في فترة الأمويين وما

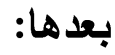

" فالحسن البصري - رحمه الله - يُهيب به أحد أصحابه أن ياخل على الأمراء فيأمرهم وينهاهم ويسدي النصيحة إليهم ، فيقول له الحسن

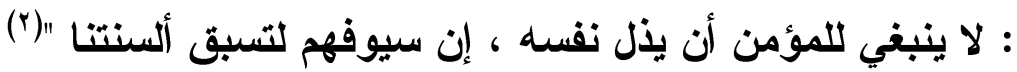

ولكنتا نخطئ في الحكم إذا قلنا بالتعميم فعناصر الإيجاب تتبدى في بعض الحكام ، وفي تنويع الحسن البصري الموفق . حين أحس بالعاطقة

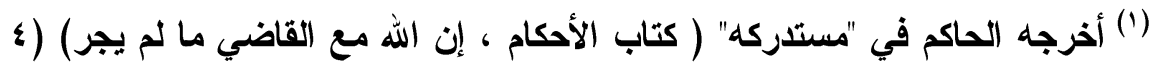

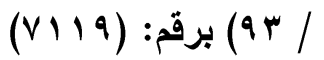

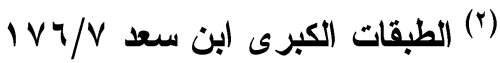


الاينية عند الخليفة الراشد عمر بن عبد العزيز فكتب له ينصحه ووجد الخليفة في كلام الحسن البصري مسحة روحية متعاليه وكان حرص البصري على نصح الخليفة من أسبابه " أنس الحسن إليه وعلم قبوله منه : كتب إليه يعظه وينصحه ويذكره "(1)

\section{انهراف السلطة الهاكمة ، هل يوجب الخروج عليها ؟}

تسؤل يهز مسلمات الفكر في حق الحاكم على الأمة من تقديم النصح

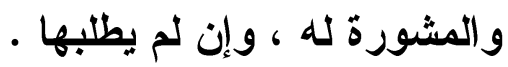

فإذا كانت النصيحة متعلقة بحقوق الناس ، وظلم الرعية ، ولم يقبل الحاكم النصح برفع الظلم عن الرعية وإنصاف الخلق وإقامة العدل في

فهل يجوز الخروج عليه بعد النصح والتأكد من غبائه وانعدام روئيته

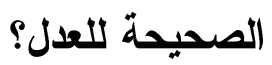
هناك عند أهل السنة ما يشبه الإجماع : على أن الحاكم - في هذه الحالة الظالمة - لا يعزل ، ولا يصح الخروج عليه ، وأكثر من ذلك على الأمة الطاعة ، والصبر حتى يحدث الله أمرا كان مفعولا والتبرير المسبب للصبر على الحاكم حتى يغير الله الأمر • استدل أهل السنة على ذلك بنصوص شرعية عديدة نذكر منها :

$$
\text { (') (بن الجوزي / سبرة عمر بن عبد العزيز صع با }
$$


قول النبِي

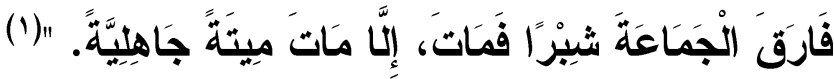

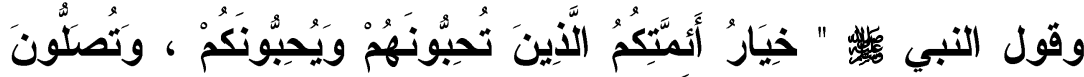

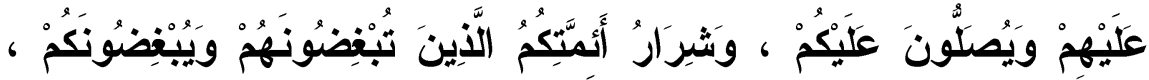

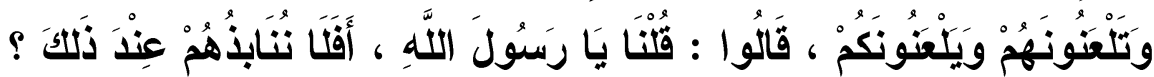

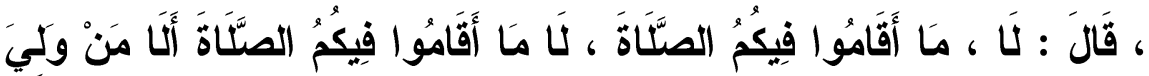

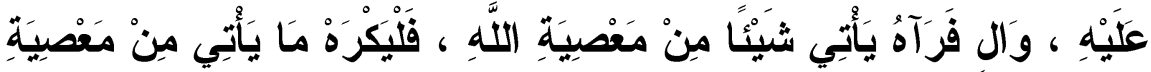

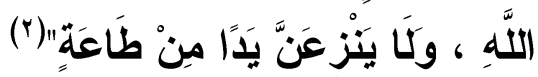

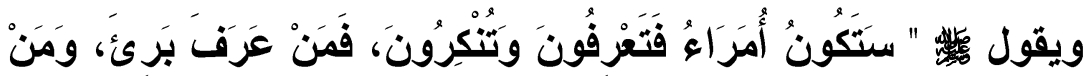

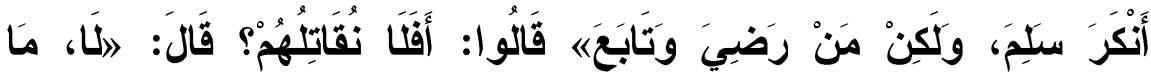

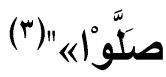

وفي حديث سلمة بن يزيد الجعفر قَال "يَّا نَبَيَّ اللَّهِهِ ، أَرَآَيْتَ إِنْ

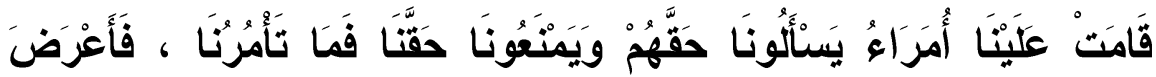

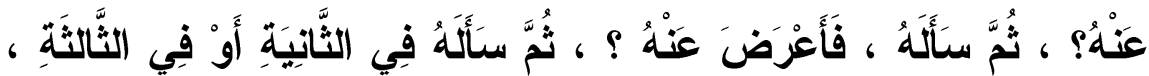

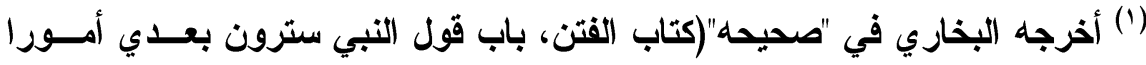

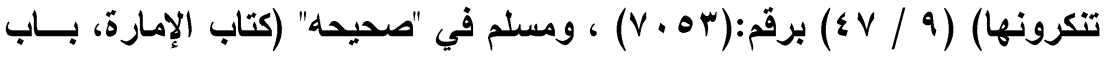

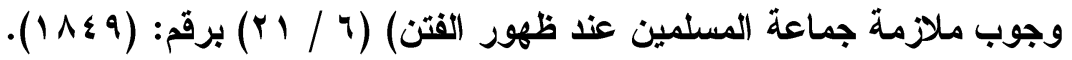

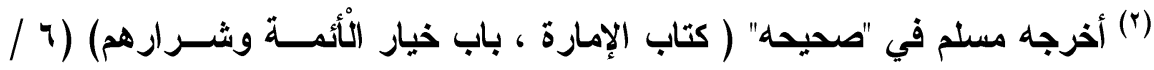

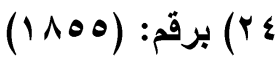

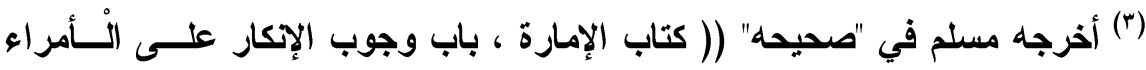

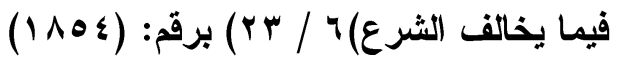




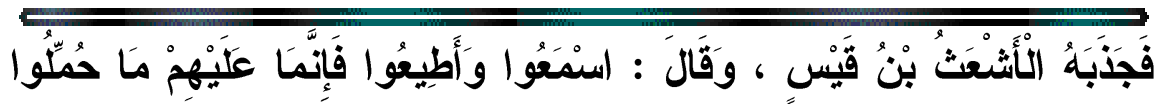

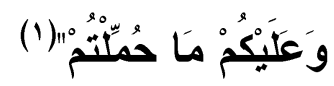

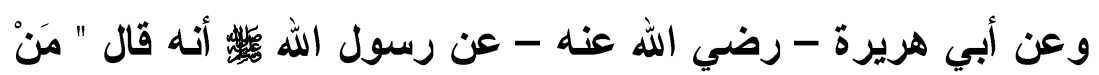

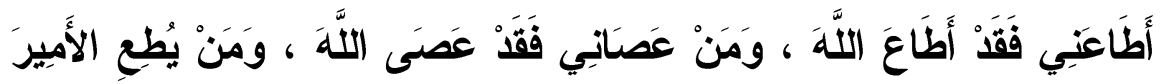

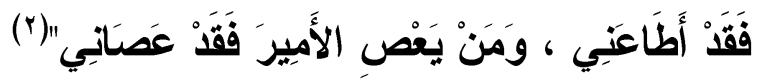
وعن أبي هريرة - رضي الله عنه - قال : قال رسول الله

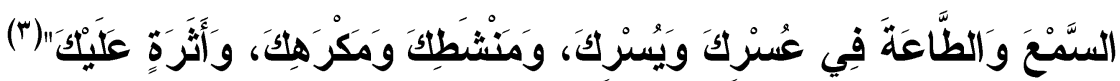
وعن عبادة بن الصامت - رضي الله عنه - فحدث أن رسول الله

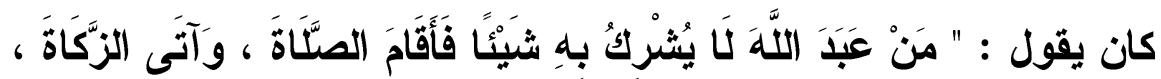

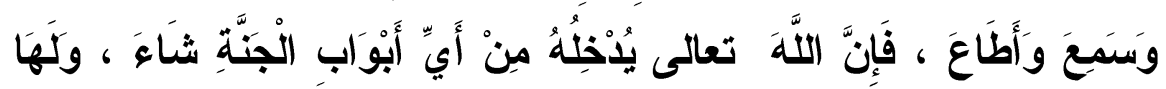

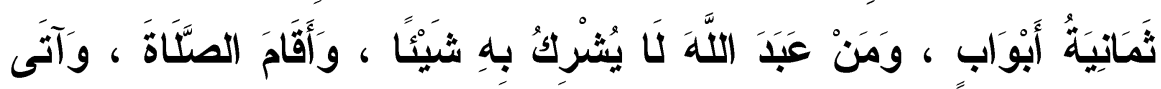

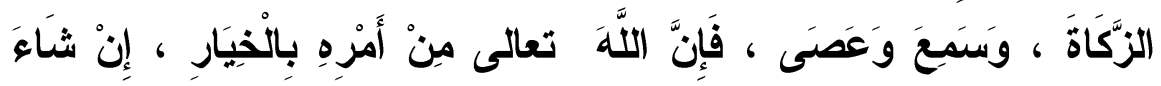

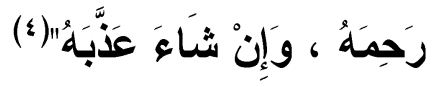

(1) أخرجه مسلم في "صحيحه" ( كتاب الإمارة ، باب فِي طاعة الْـــأمر اء وإن منعــوا

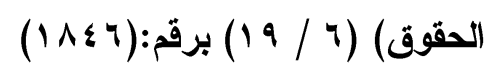

(ץ) أخرجه البخاري في "صحيحه" ( كتاب الأذان ، باب إقامة (الصف من تمام الصلاة)

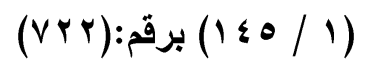

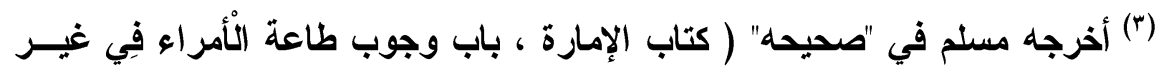

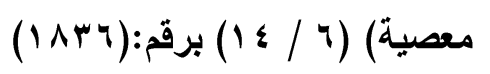

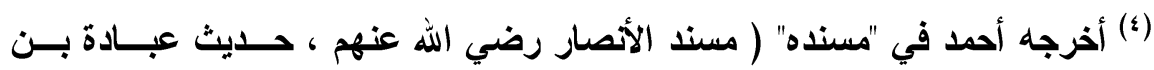

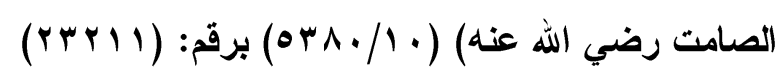




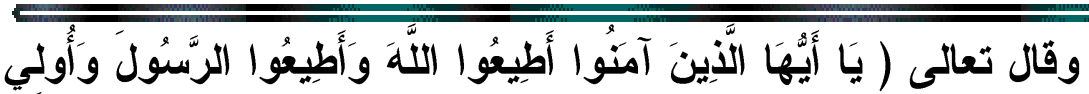

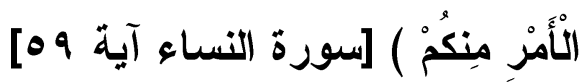

ومن هنا فالواجب احتمال الضرر الآني لرفع ضرر أعظم ، وهو

الفتنة وتفرق الأمة

ويؤكد مضمون هذه المقولة الأخيرة ما نراه من حمل الناس على

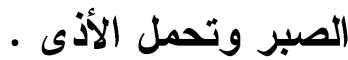

$$
\text { يقول الإمام النووي - رحمه الله - : }
$$

" باب وجوب طاعة الأمراء في غير معصية وتحريمها في المعصية: أجمع العلماء على وجوبها - أي الطاعة -، وتحريمها في المعصية.

نقل الإجماع على هذا القاضي عياض "(') وقال الإمام النووي أيضا :

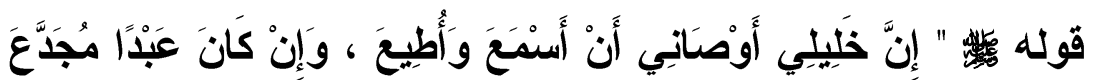

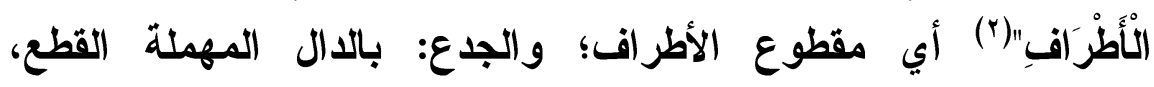
والمجدع أراد العبد لخسته، وقلة قيمته ومنفعته، ونفرة الناس منه. وفي هذا: الحث على طاعة ولاة الأمور ما لم تكن معصية.

وقال الإمام ابن حجر كرحمه الله - : والحكمة في الأمر بطاعتهم -

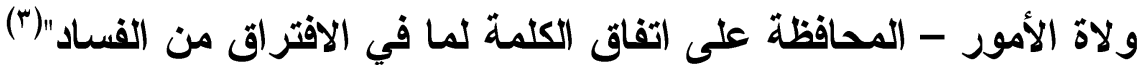

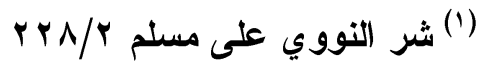

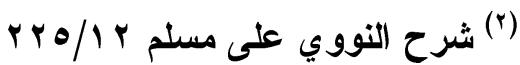

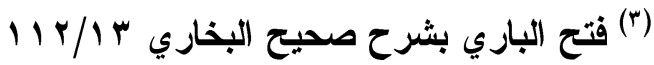


وهكذا يتبدى حس القبض على قضية نؤمن بها - طاعة ولاة الأمور-

وهنا نتساعل : مالأمور التي تنعقد بها الإمامة ؟ ومتى يجوز الخروج عليه ؟ أنسا

تنعقد الإمامة بأحد أمور أربعة : 1-بعقد أهل الحل والعقد . r-باستخلاف الإمام r-بجعل الإمام الأمر شورى

ع -تغليب ذي شوكة على السلطة وأخذه بزمام الأمور فتنعقد له .(1) وهذا تتأكد الإمامة بالأمور الأربعة أو بواحدة منها . وقا يقال هنا : إن الخروج على ولاة الأمور وقتالهم حرام بإجماع السلمين ولو كانوا فسقة ظالمين وقد تضافرث النصوص الثرعية لتأكيا ذلك. ونحب أن نؤكد أن الأي يعنينا الآن هو : متى يجوز الخروج على

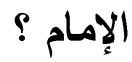
" قال القاضي عياض : أجمعوا على أن الإمامة لا تنعقد للكافر وعلى ألى أنه لو طرأ عليه الكفر اتعزل : وكذا لو ترك الصلاة والاعاء إليها ... سقطت طاعته ووجب على المسلمين القيام عليه وخلعه ونصب إمام (1) فصل الخطاب في مواقف الأصحاب تأليف الثيخ محمد صالح أحمــ ص99 19

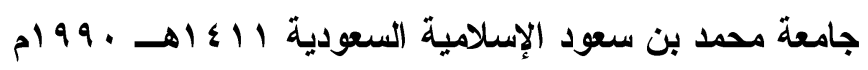


عادل إن امكنهم ذلك فإن لم يقع ذلكـ... لم يجب القيام وليهاجر المسلم

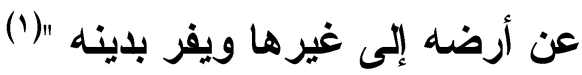

ويبدو أن الإمامة " لا تنعقد بفاسق ابتداء ـ فلو طرأ على الخليفة أو

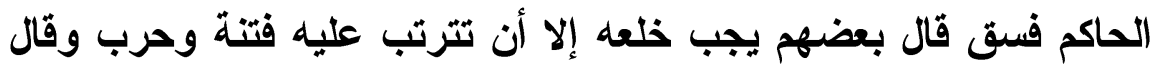

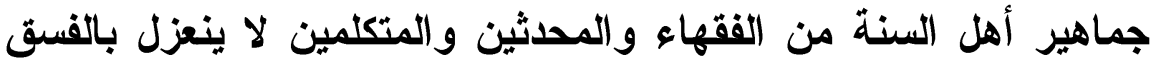
و الظلم وتعطيل الحقوق ولا يخلع ولا يجوز الخروج عليه بذلك بل يجب لهن

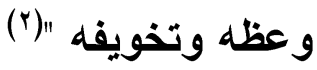

وقد قيل لجمهور العلماء سبقكم إلى هذا عزل الناس الحجاج لفسقه " وحجة الجمهور أن العزل ليس لمجرد الفسق بل لما غير من الثرع وظاهر من الكفر قال القاضي " قيل إن هذا الخلاف كان أول ثم حصل

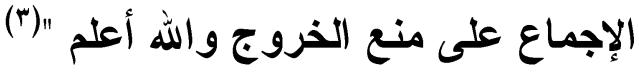
وقيل " الإجماع على حرمة الخروج على الجائر إنما أراد الإجماع

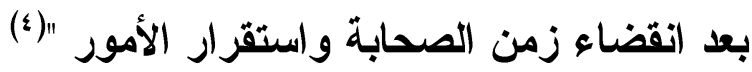

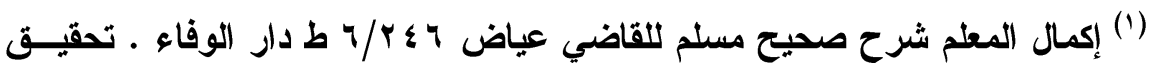

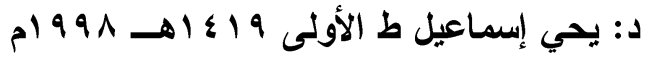

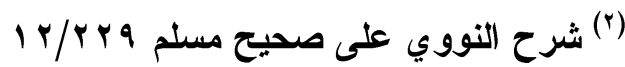

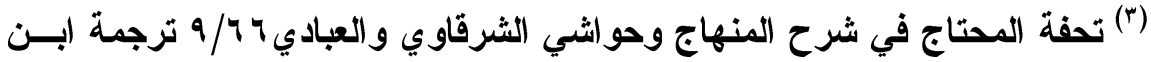

$$
\begin{aligned}
& \text { حجر الهيثي }
\end{aligned}
$$

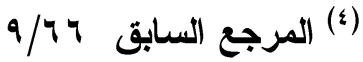


ومهما يكن من شيع فقا ظلت قضية عدم انعقاد الإمامة لفاست ابتداء تتردد بين العلماء حتى قال الإمام القرطبي " ولا خلاف بين الأمة

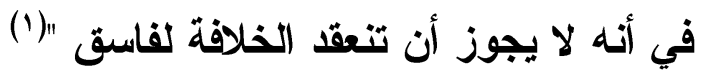
و العلماء لم يجدوا رهقا في الوقوع على كثير من الأدلة على هذا

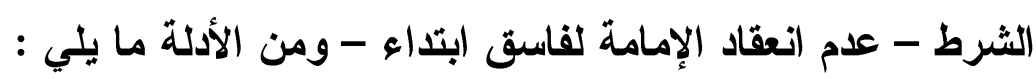
ا-لا خلاف في الحكم على أن عهد الله لا يناله الظالمون والاليل

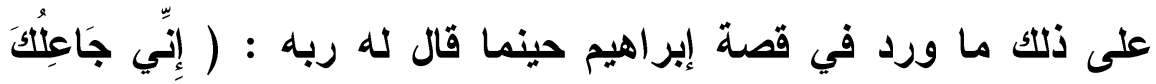

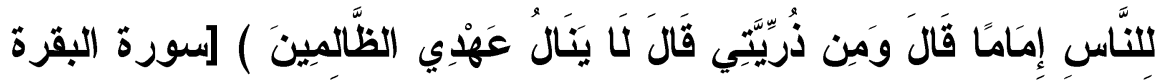

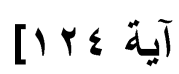

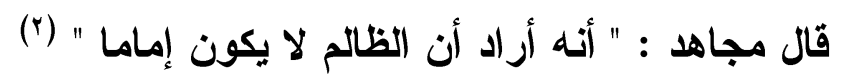

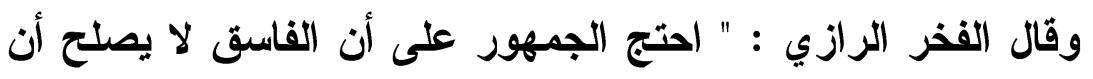

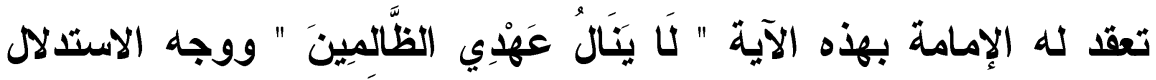

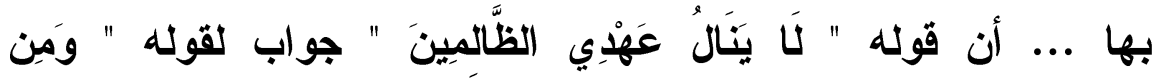

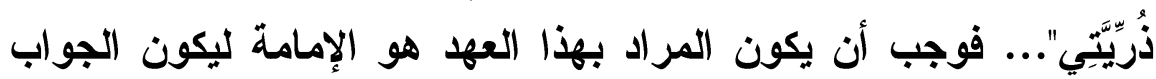

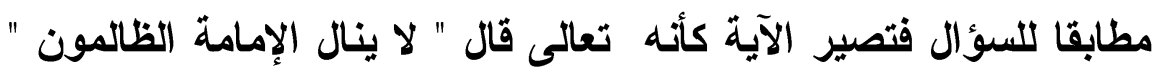

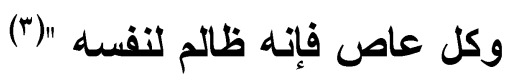
r-ولما كان الاتجاه الايني يؤكد التبين عند قول التهان الفاست كما في

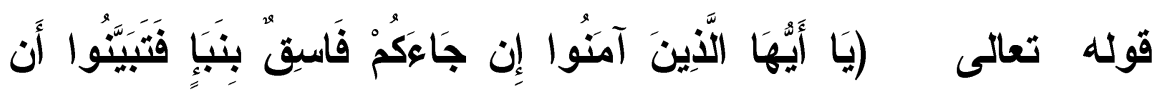

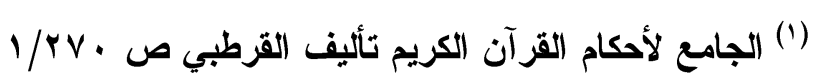

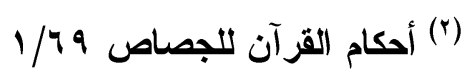

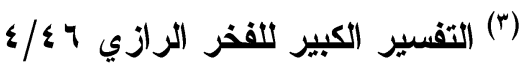




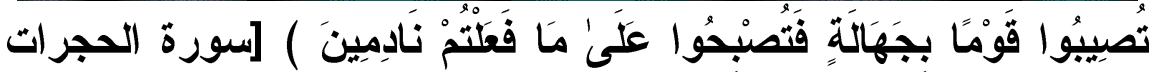

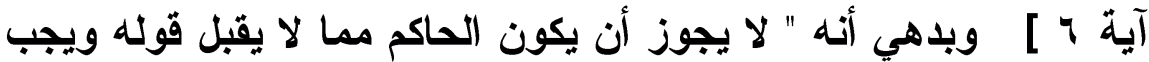
التبين عند حكمه ، ولأن الفاسق لا يجوز أن يكون شاهدا فلا يكون

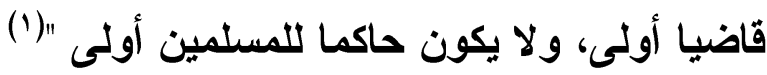
ب-و لا نحسب أننا في حاجة إلى تأكيد أن الله سبحانه و تعالى ينهانا

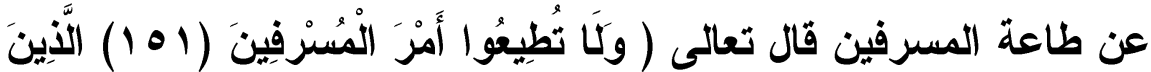

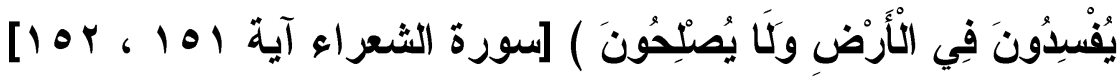
ع -ونثترك في الاتفاق على أن المقصد الأسمى من تنصيب الخليفة

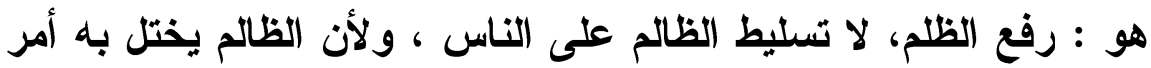
الاين والانيا فكيف يصلح للولاية ، والجميع يناثدونه على الاوام أن الن النال يظل قريبا من نبع النصوص الثرعية. قال الإمام الجويني " و الأب الفاسق على فرط حبه وإثفاقه على

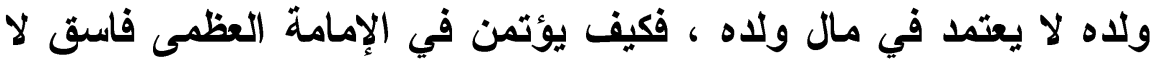

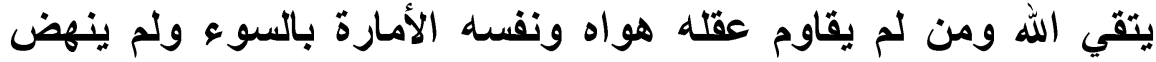

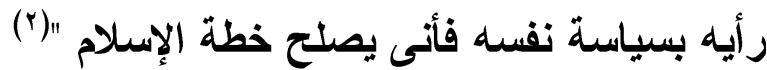
ويؤكد الماوردي أن الفسق الذي تزول به العدالة قسمان : الأول : ما تابع فيه الثهوة . الثاني : ما تعلق فيه بثبهة .

(1) المغني والثرح الكبير تأليف : (ابن قدامة r/r/1)

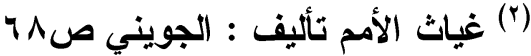


فأما الأول: فمتعلق بأفعال الخوارج وهو ارتكابه للمحظورات ،

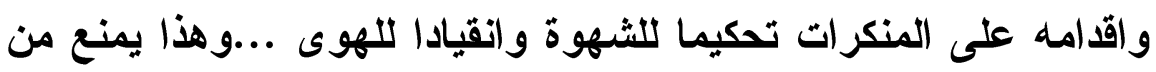

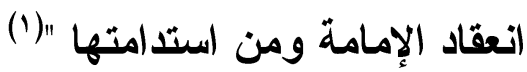

وأما الثاني : فتعلق بالاعقاد والتأويل بثبهة تعترض فيتأول لها خلاف الحق ، فقد اختلف العلماء فيها ، فذهب فريق من العلماء إلى أنها

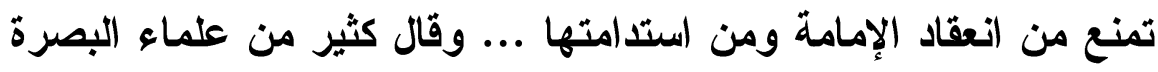

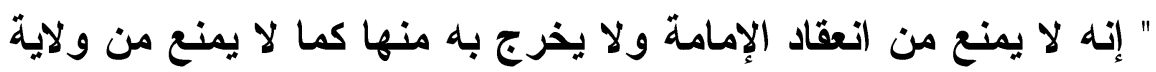

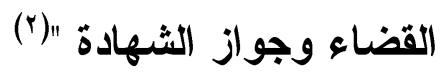
وعلى الرغم من أن العلماء قالوا بعدم ولاية الفاسق ابتداء فإن "

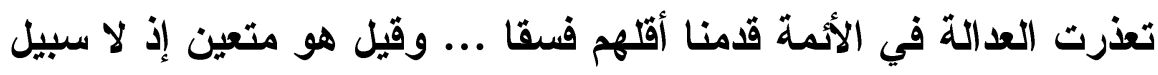

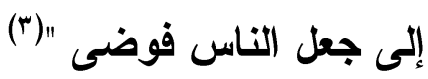
ولعلنا لا نخطئ في دراستنا لفكر ابن حزم في قضية الخروج على الحئ الحاكم إذا قلنا : إن الرجل من المتثثددين في طلب الخروج على الحاكم

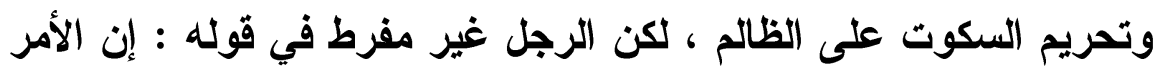

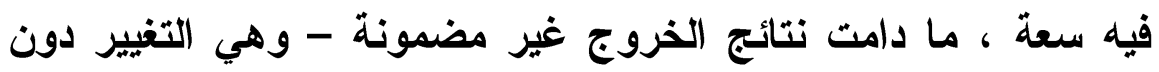

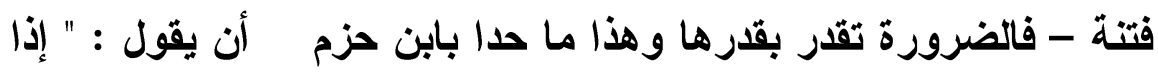

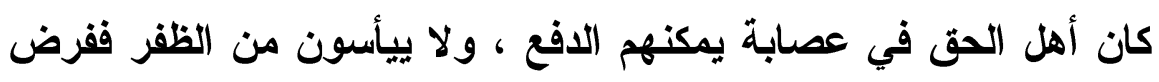

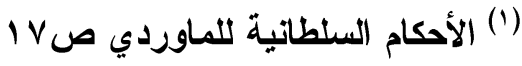

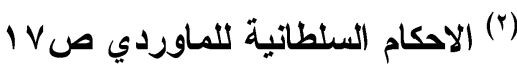

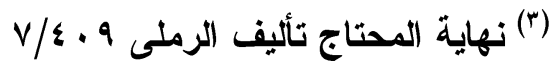


عليهم ذلك ، وإن كانوا في عدد لا يرجون الظفر - لقتهم وضعف

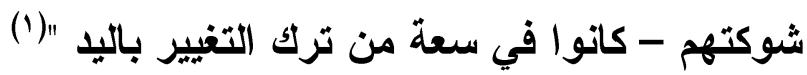
وقد قاد الغزالي - في قضية الخروج على الحاكم الظالم - اتجاه الخروج إن قدر على استبداله من غير إثارة فتنة فالتغيير عند الغزالي محكوم بشرط عدم الفتنة... ثم يثب مفكرنا - الغزالي - إلى تهيئة الأمة لعدم التغيير إذا كان فيه إثارة فتن . ل ويتبدى بوضوح أن واقع الصراع - على مر العصور - بين الحاكم الظالم و الرعية فيه : المراقبة و المحاذرة و المخاثنة .... الخخ التي تؤدي إلى هلاك النفوس والأموال ، ولكل هذا الاتجاه - علدم اثارة الفتن -

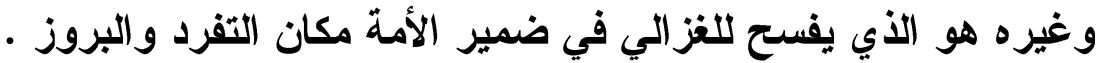
يقول الغزالي : " الأي نراه ونقطع به أنه يجب خلعه إن قدر على أن يستبلل عنه من هو موصوف بجميع الثروط من غير إثارة فتنة ، وتهييج قتال لا ندري عاقبته ، وربما يؤدي إلى هلاك النفوس هن

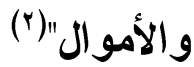
ومن الحق أن يقال : يثترط في الخروج على الحاكم الظالم : 1-عدم حدوث فتنة هي أعظم من الصبر عليه . r-توفر المنعة والثوكة والغلبة لاى الخارجين حتى يمكنهم عزله ـاعله (1) الفصل في الملل و الأهو واء والنحل تأليف ابن حزم -الأمر بالمعروف والنهي عـن

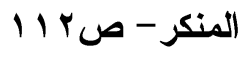

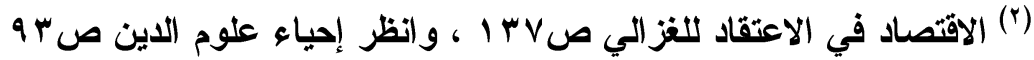


مجلة كلية الكرإسات الإسلإمية والعريبية بنات بنمي سويفه العذد العاشر

r-يشترط البعض أن يكون في الخارجين من هو أهل للقيام بهذه

(التبعة . (1)

ولكنتا نرى أنه لا يشترط للتوصل إلى هذه الذرى - الحاكم - من

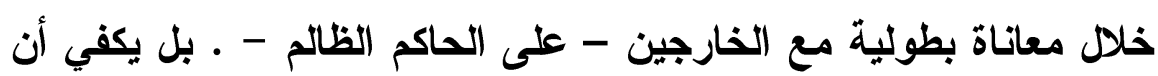

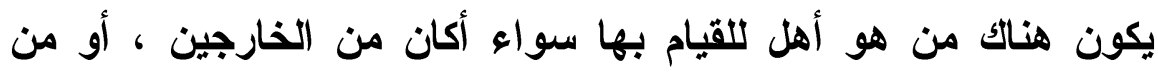

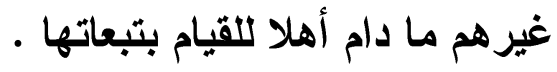
اهـ.

(1) على طريق العودة إلى الإسلام رسم لمنهاج وحل لمشكلات تأليف : محمد ســيد

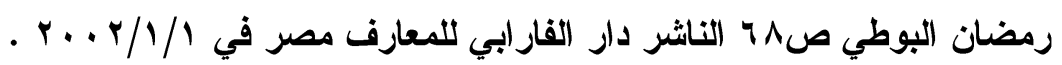




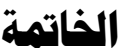

وهنا نتساعل : هل يستطيع بحثنا - فتنة تكفير المسلمين ...- أن يعطي نتائج ت تعالى على الصراخ وتقرير المقولات الجامدة حول هذه القضية الخطيرة -التكفير -؟ ونجيب على الفور ـ أجل تستطيع نتائجنا أن تنهض بهذه المهمة الخطيرة ، وأن تصل إلى تأملات الماضي والحاضر لتجو بالأمة من الامار والهلاك الأي تسبب فيه تكفير المسلمين ومن النتائج :

أولا : يبدو أن قضية تكفير المسلمين قد نالت من الأمة حتى أو جعتها تماما ؛ فجناية التكفير على الإسلام والمسلمين أخطر ما نجده على الساحة الفكرية الآن؛ تكفير يعقبه قتل وتدمير !

ثانيا : لابل من معرفة ماضي القضية - التكفير - حتى نبصر مواضع أقامنا وهي تخطو نحو الغد الأي يؤكد أن الهـف السامي لكل جهودنا هو التفكير في الوسبلة والغاية . وحتى لا نضل في سماء التأملات فإن : الوسيلة قبل الغاية تخطيطا . والغاية قبل الوسيلة دافعا ـ والغاية تأتي بعد الوسيلة و اقعا . ثالثا : ترفض فرقتا الشيعة وأهل السنة الحياة الوادعة التي تقوم على قاعدة " نتعاون فيما اتفقنا عليه ويعذر بعضنا بعضا فيما اختلفنا فيه " ... فلا يوجد تبرير مسبب لصراعات طويلة دارت رحاها بين الفرقتين 
ذهبت فيها دماء زكية من الطرفين بسبب التعصب المقيت الذي ذهبت

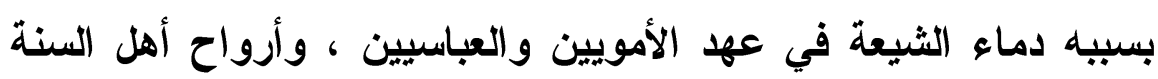

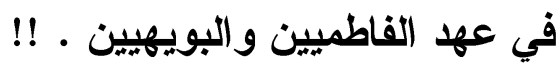
رابعا : التعصب يفتح فتنة مأساوية ... طالت أحداثها الخطيرة

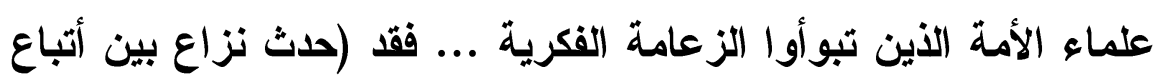

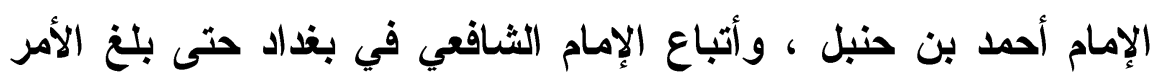

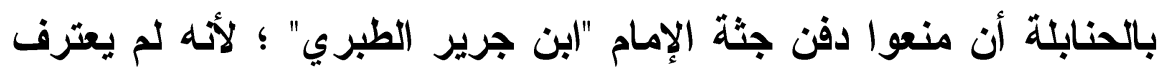

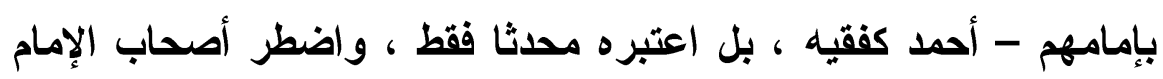

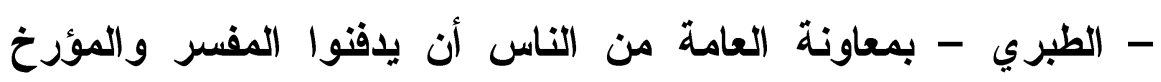

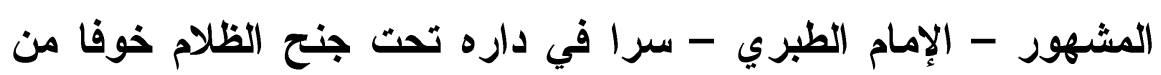

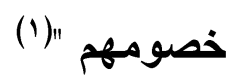

خامسا : استمر مسلسل التكفير للمسلمين والقتل بين الأمة ؛ لتمزيق وحدة المسلمين ؛ فاستعمر التتار والصليبيون دولهم ، وانتهكوا حرماتهم

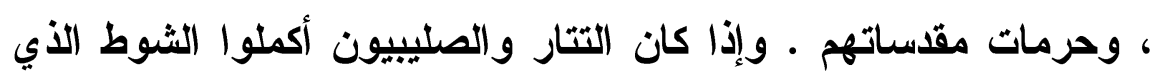

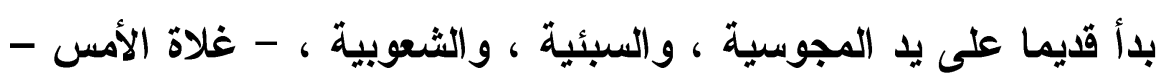

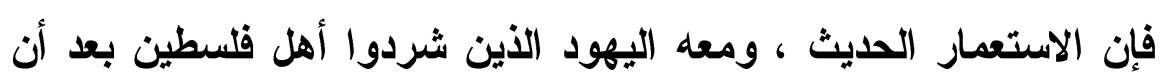

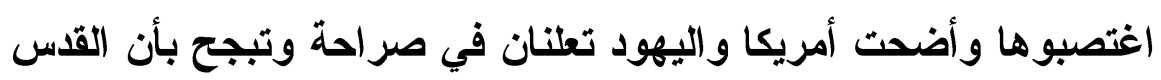

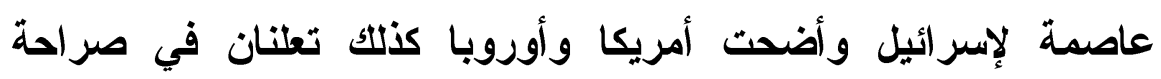

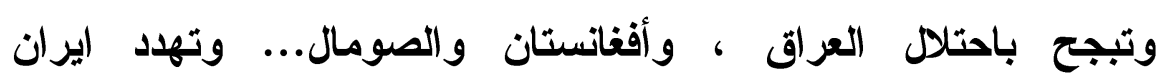
و السودان وسوريا ولبنان وغيرها ـ البناف

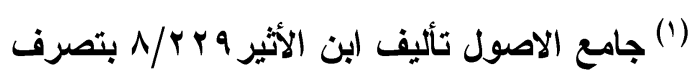


سادسا : القلوب الآن تعتصر أسى وألما وحزنا لما يحدث من إيران - الثيعة - تجاه دولة المقدسات - السعودية - أهل السنة من تلويح بالاعتداء. بل وصل الأمر إلى الاعتداء بالفعل .

سابعا : يتوجه العالم الإسلامي إلى الأزهر الثريف أعرق مؤسسة

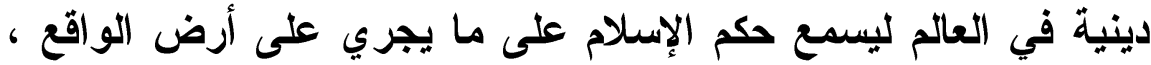

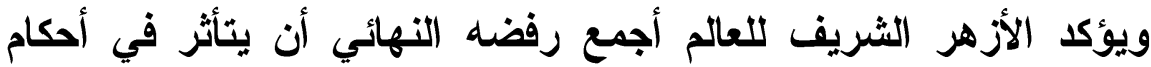
الثريعة بلوم لامم أو عذل عاذل ما فأحكام الاين الإسلامي عنده لا تقبل المساومة ، ولا تصيخ إلى هاجس من هنا أو هناك و الواقع أننا لا نعاني طويلا لنفهم أن الإعلام بل رجال الفكر و... حاولوا التأثثر على الأزهر الثريف بنوع من الاستدعاء العاطفي ليحكم على الجماعات الإرهابية دواعش وغيرهم - بالكفر ـ لكن الأزهر الثريف الواقف عند حدود الله

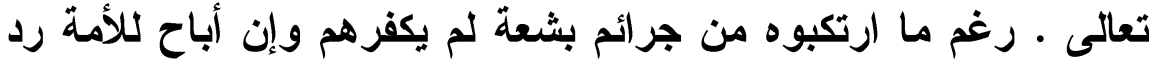

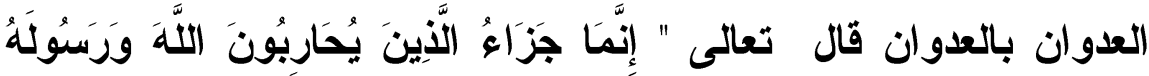

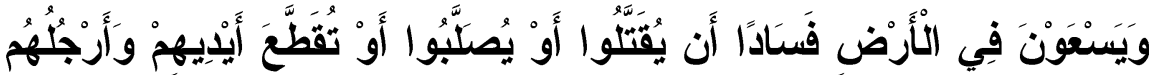

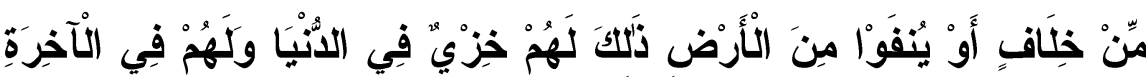

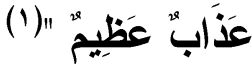

بل إن الازهر الثريف قد فطن بصفاء رؤيته الفطرية الإسلامية

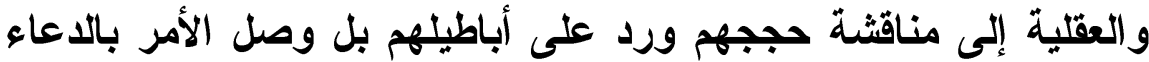
لهم بالهداية وطالبهم بالتوبة التي تصل إلى أعراف الفيض الاههي الغافر 
وبعد

فقد أثرنا في هذه الارسة العقدية أن تتعدد جوانب النصوص شكلا ومضمونـا ـ حتى يمكن أن يكون المردود الفكري شاملا لأبعاد قضية تكفير المسلمين ما أمكن . فهناك كفر التصريح ... وكفر التأويل ... وكفر دون كفر ... وتكفير من لم يكفر الكافر . وهنائ قضايا تتصل بالقضية - التكفير - فهناك الحاكمية والتثريع ... وهناتك الولاء والبراء ... وهناك الشورى في الإسلام ... وهناك الاين والنصيحة ... وهناك انحراف السلطة الحاكمة والخروج عليها ... إلى آخر ما هناتك من

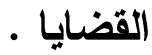

وكل ما ترجوه هذه الصفحات ... هو أن تكون قد قالت شيئا مجديا في قضية فهمها للنصوص الشرعية ، وفي دعوتنا للتعامل معها على أنها ( مجاسدة وكشف ) وليس مجرد مهارات لغوية فارغة ومغلوطة . ولهذه القضايا - فيما نعتقد - ينبغي أن تتوجه الاراسات العقدية دائما. فقد اتخنت عقول أبناء الأمة بتعميمات فكرية مغلوطة ربما لأنها لم تلتق بالفكر العقدي الصحيح إلا من خلال أحكام متداولة عند غير المتخصصين ، وتلك بداية انحطاط الفكر . 


\section{قائمة بأهم المراجع}

\section{السنة النبوية المطهرة}

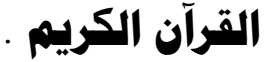

1-الأحكام السلطانية تأليف علي بن محمد الماوردي . طبعة دار

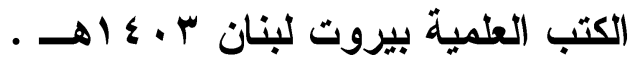

r-إحكام الفصول في أحكام الأصول ـ تأليف : الباجي - أبو الوليد سليمان بن خلف الباجي ـ تحقيق : الاكتور عمران علي العربي • الناشر

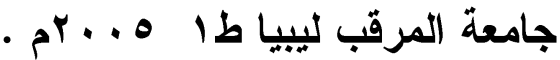

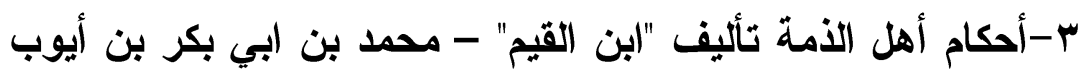
بن سعد شمس الدين ابن قيم الجوزية . تحقيق : يوسف بن أحمد البكري ، وشاكر بن توفيق العاروري • الناشر رمادي للنشر الامام

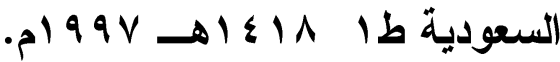

ع-الإحكام في تمييز الفتاوى عن الأحكام وتصرفات القاضي والإمام • تأليف : "القزافي" - أبو العباس شهاب الاين أحمد بن ادريس بن عبدالرحمن المالكي الشهير بالقرافي اعتنى به : عبدالفتاح أبو غدة . الناشر الار الإسلامية للطباعة والنشر والتوزيع حلب سوريا . طب

$$
\text { - م) } 990 \rightarrow 1 \leqslant 17
$$

ه-إحياء علوم الاين تأليف حجة الإسلام محمد بن محمد الغزالي

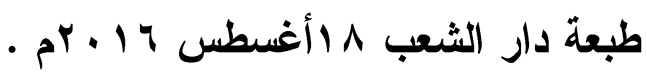

צ-الأصول والفروع تأليف ابن حزم • تحقيق الاكتور : عاطف

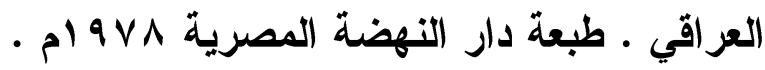


V- إعلام الموقعين عن رب العالمين ـ تأليف "(بن القيم" - محمد بن أبي بكر بن أيوب بن سعد شمس الاين ابن قيم الجوزية ـ الناشر دار

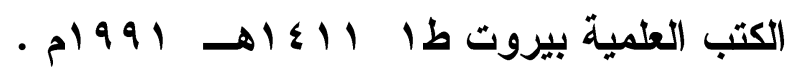
^-الأعمال الكاملة تأليف الإمام محمد عبده. دراسة وتحقيق الأستاذ

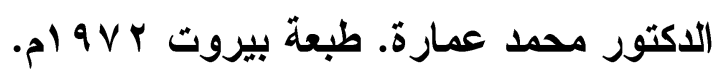
9-الاقتصاد في الاعتقاد المؤلف أبو حامد الغزالي - أبو حامد محمد بن محمد الغزالي الطوسي . تحقيق عبدالله محمد الخليلي طا • • 1 - الاقتصاد في الاعتقاد تأليف : الغزالي الطوسي - أبو حامد

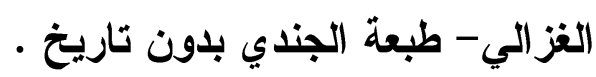
1 - الأمثال في القرآن ـ تأليف: ابن القيم - محمد بن أبي بكر بن أيوب بن سعد شمس الاين ابن قيم الجوزية ـ الناشر مكتبة الصحابة مصر طنطا. تحقيق : ابو حذيفة إبراهيم بن محمد طا ؟ . ع اهـ - $) 919$

r ا - إيثار الحق على الخلق في رد الخلافات الى المذهب الحق من أصول التوحيد . تأليف :"(بن الوزير" محمد بن إبراهيم بن علي بن المرتضى بن المفضل الحسيني القاسمي ابو عبدالله عزالاين اليمني .

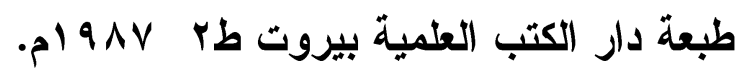
rا - بستان الأحبار مختصر نيل الأوطار المؤلف: فيصل بن عبد العزيز بن فيصل ابن حمد المبارك الحريملي النجدي. الناشر: دار إثبيليا

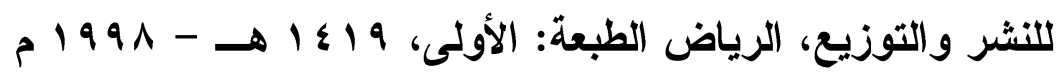


ع ا - بغية التمام في تحقيق ودراسة مسعفة الحكام على الاحكام . تأليف : التمرتاشي - محمد بن عبدالله بن أحمد شهاب الاين طبعة مكتبة المعارف مصر 999 أم 99

ه - تبصرة الحكام في أصول الأقضية ومناهج الأحكام ـ تأليف : إبراهيم شمس الاين محمد بن فرحون اليعمري المالكي برهان الاين أبو الوفاء • تحقيق : جمال مرعشلي · الناشر دار عالم الكتب للنشر

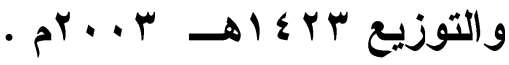
7 ا 1 - تحرير المعنى السديد وتنوير العقل الجديد في تفسير الكتاب المجيد "التحريز والتنوير" تأليف: محمد الطاهر بن محمد بن محمد

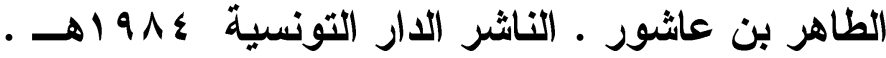
IV من تفسير الكتاب المجيا " تأليف محمد الطاهر بن محمد بن محمد الطاهر بن عاثور التونسي . الناشر الارار التونسية للنشر تونس - $19 \wedge \varepsilon$

1 - تحفة المحتاج في شرح المنهاج وحواشي الثرواني والعبادي • تأليف : الهيتمي - أحمد بن محمد بن علي بن حجر الهيتمي • الناشر المكتبة التجارية الكبرى بمصر لصاحبها مصطفى محمد . طبعة دار

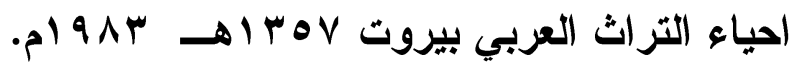
9 1 - تفسير البحر المحيط ـ تأليف: "ابو حيان" - محمد بن يوسف الثهير بأبي حيان الأندلسي ـ الناثر دار الكتب العلمية ـ لبنان بيروت

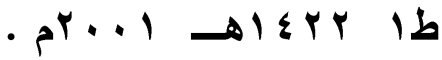
• r- التفسير البياني للقرآن الكريم . تأليف : عائشة بنت عبد الرحمن بنت الثاطئ ـ الناشر دار المعارف • 99 ام . 
اب- تفسير الجلالين تأليف : جلال الدين احمد المحلي ، وجلال الدين عبد الرحمن بن ابي بكر السيوطي . الناشر دار الحديث القاهرة $.1 b$

r r r تفسير القرآن الحكيم ( تفسير المنار ) تأليف : محمد رشيد بن علي رضا بن محمد شمس الاين بن محمد بهاء الدين منلا علي

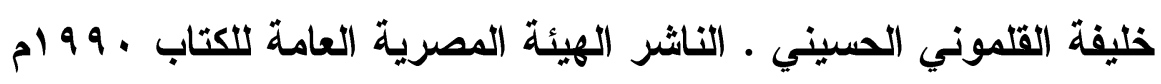

r r - تفسير القرآن العظيم للإمام ابن كثير فقيه المفسرين ومفسر

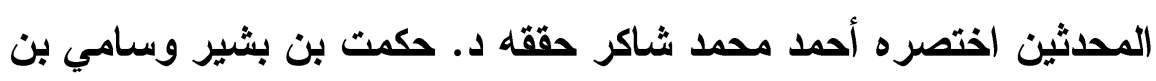

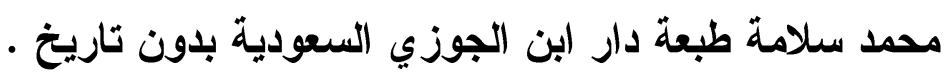

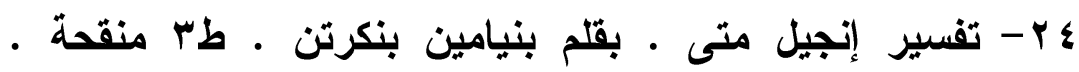

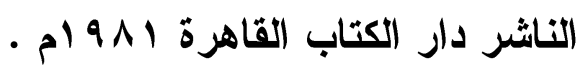

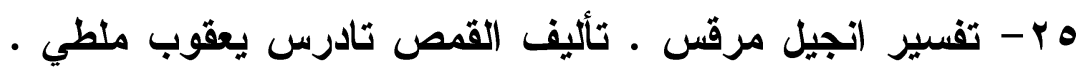

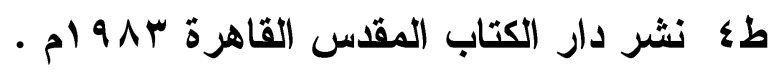

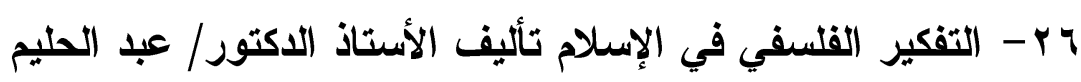

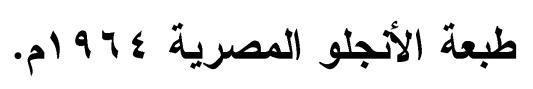

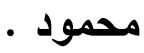

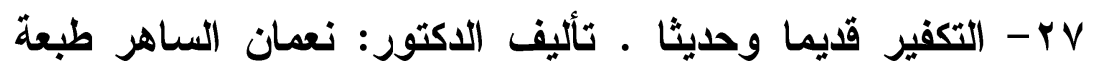

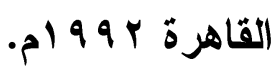

^ץ - تمهيد لتاريخ الفلسفة الإسلامية ـ ت تأليف : الثيخ مصطفى

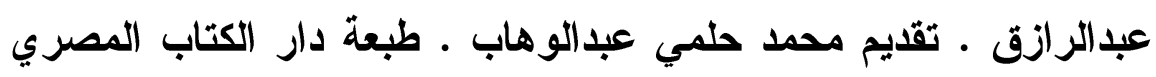

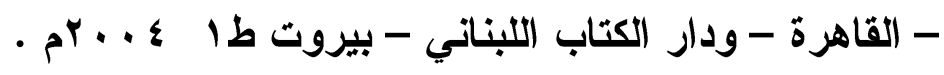

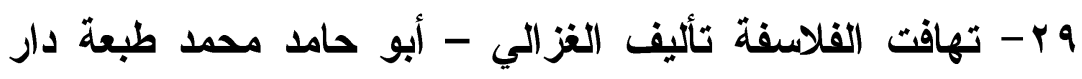

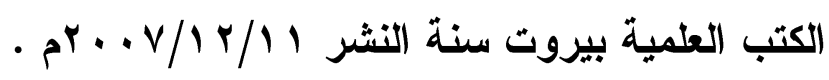


• ب- تيسير الكريم الرحمن في تفسير كلام المنان ."تفسير السعدي" تأليف: عبد الرحمن بن ناصر بن عبد الله السعدي ـ تحقيق: عبد الرحمن

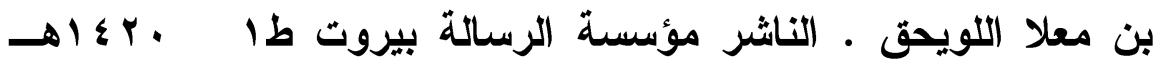
- . .

اب- جامع البيان عن تأويل آى القرآن "تفسير الطبري" تأليف : محمد بن جرير بن يزيل بن كثير بن غالب الأملي ، أبو جعفر الطبري • تحقيق الاكتور : عبد الله بن عبدالمحسن التركي • الناشر دار هجر

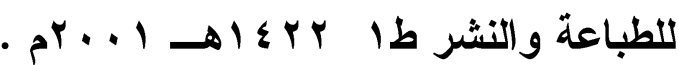
r r- جامع العلوم والحكم في شرح خمسين حديثا من جوامع الكلم • تأليف: "ابن رجب الحنبلي" زين الدين عبد الرحمن بن أحمد بن رجب بن الحسن السلامي البغدادي الامشقي الحنبلي .تحقيق: شعيب الأرناؤوط - إبراهيم باجس . الناشر مؤسسة الرسالة بيروت . ط V

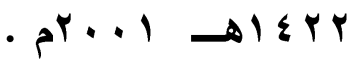

بr- الجامع الكبيز - سنن الترمذي- تأليف محمد بن عيسى بن سورة بن موسى بن الضحالك الترمذي ، (بو عيسى • تحقيق : بشار عواد معروف ـ الناثر دار الغرب الإسلامي بيروت 9919 ام . ع - جامع بيان العلم وفضله ـ تأليف أبو عمر يوسف بن عبدالله بن محمد بن عبد البر بن عاصم النصري القرطبي • تحقيق : أبي الأثبال الزهري ـ طبعة دار ابن الجوزي المملكة العربية السعودية طا

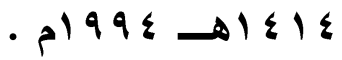

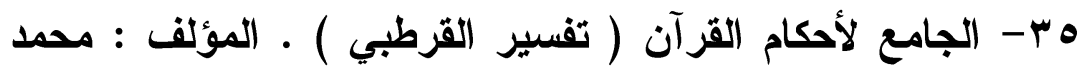
بن أحمد الأنصاري القرطبي أبو عبد الله . تحقيق: أحمد البردوني 
وابراهيم أطفيش • طبعة دار الكتب المصرية القاهرة طن ع عالهـ - 1978

צس- جمل من أنساب الأشراف ـ تأليف "البلاذري" - أحمد بن يحيى بن جابر داود البلاذري ـ تحقيق سهيل زكار ورياض الزركلي ـ الناثر

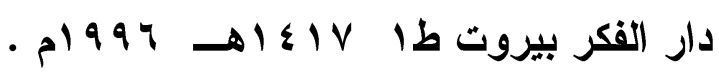

الخراج تأليف : ابو يوسف القاضي - ابو يوسف يعقوب بن إبراهيم بن حبيب بن سعد بن حبنة الأنصاري ـ الناشر المكتبة الأزهرية للتراث . تحقيق : طه عبد الرؤوف سعد ، وسعد حسن محمد . طr

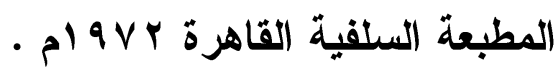
^ץ- دراسات في الفلسفة الإسلامية تأليف الدكتور محمود قاسم •

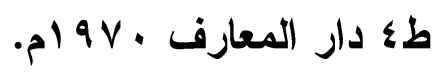

q - الدين - دراسة لتاريخ الأديان - تأليف الاكتور محمد عبدالله

$$
\text { دراز طب دار القلم القاهرة م ـ } 1 \text { • ب م. }
$$

• ع - روح المعاني في تفسير القرآن العظيم والسبع المثاني "تفسير الألوسي" تأليف: شهاب الاين محمود بن عبد الله الحسيني الألوسي . تحقيق :علي عبد الباري عطية ـ الناشر دار الكتب العلمية بيروت ـ طا لابل $\rightarrow 1 \leqslant 10$

اء - زاد المعاد في هدي خير العباد تأليف ابن القيم محمد بن ابي بكر بن ايوب بن سعد شمس الاين ابن قيم الجوزية ـ الناشر مؤسسة

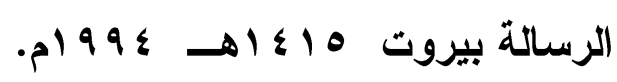

r ـ سنن ابن ماجة تأليف ابو عبدالله محمد بن يزيد القزويني . تحقيق محمد فؤاد عبد الباقي ـ الناشر دار احياء الكتب العربية الحلبي

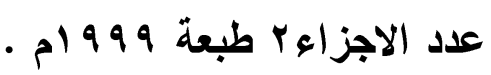


r بـ سنن أبي داود - أبو داود سليمان بن الأشعث بن اسحاق ... الأزدي السجستاني • تحقيق محمد محي الاين عبد الحميد • طبعة

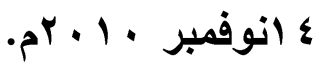

ع - سنن أبي داود . تأليف أبو داود سليمان بن الأثعث بن إسحاق بن بشير بن شداد الازدي السجستاني ـ تحقيق محمد محي الاين عبد الحميد . الناثر المكتبة العصرية صيدا بيروت . عدد الأجزاعء. . 1997

هـ - السياسة الشرعية تأليف محمد بن شاكر الشريف طبعة دار المعارف القاهرة ه 979 ૫ ـ - السياسة الشرعية في اصلاح الراعي والرعية ـ ـ تأليف "(بن تيمية" - تقي الاين ابو العباس أحمد بن عبد الحليم بن عبد السلام بن عبد الله أبي القاسم بن محمد ابن تيمية الحراني الحنبلي الامشقي •

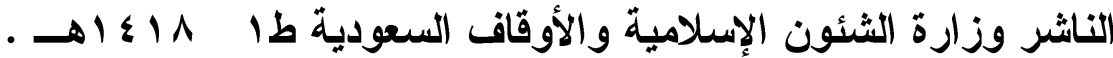
\& V أيوب الحميري المعافري، أبو محمد جمال الدين. تحقيق: مصطقى السقا وابراهيم الابياري وعبدالحفيظ الشلبي.الناشر مطبعة مصطقى البابي

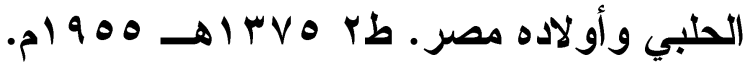
^ ـ - سيرة عمر بن عبدالعزيز علي ما رواه الإمام مالك بن أنس وأصحابه . تأليف : عبد الله بن عبد الحكم بن أعين بن ليث بن رافع . أبو محمد المصري ـ تحقيق أحمد عبيد ـ الناشر عالم الكتب بيروت لبنان - p) $91 \varepsilon \rightarrow 1 \varepsilon \cdot \varepsilon 74$ qء - شرح العقيدة الطحاوية ـ شرح عقيدة أبي جعفر الطحاوي • جمهور المذاهب الأربعة يقرون عقيدة الطحاوي التي تلقاها العلماء سلفا 
وخلفا بالقبول السبكي . حققها وراجعها جماعة من العلماء . خرج أحاديثها محمد ناصر الاين الألباني • طبعة المكتب الإسلامي بيروت

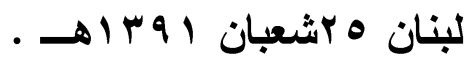
• ه شرح المقاصد في علم الكلام ـ تأليف التقتازاني - سعد الاين

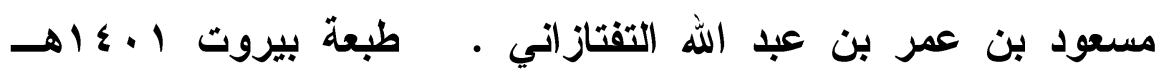
- 1911

اه- شرح النووي على مسلم ـ تأليف : النووي - أبو زكريا محي الاين بن شرف النووي ـ الناشر دار احياء التراث العربي بيروث طن . $\rightarrow$ Irar

r ه - شرح صحيح مسلم للقاضي عياض المسمى " إكمال المعلم بفوائد مسلم " . تأليف: عياض بن موسى بن عياض بن عمرون البحصبي السبتي • (بو الفضل ـ تحقيق الاكتور يحيى إسماعيل. الناشر

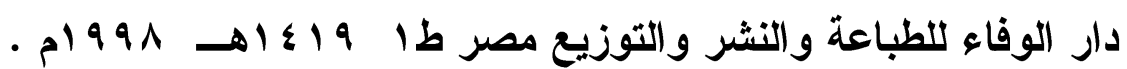
rه- شعب الإيمان تأليف "البيهقي" - أحمد بن الحسين بن علي بن موسى الحسروجردي الخرساني أبو بكر البيهقي • حققه الاكتور عبد

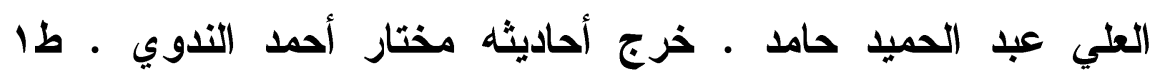

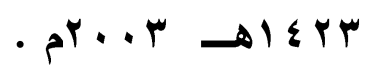
ع - صحيح مسلم - المسند الصحيح المختصر بنقل العدل عن العدل إلى رسول الله القشيري النيسابوري ـ تحقيق: محمد فؤاد عبد الباقي طبعة دار إحياء التراث العربي · بيروت ع ا نوفمبر · م ـ بام • هـ - الطبقات الكبرى ـ تأليف : ابن سعد - أبو عبد الله محمد بن سعد بن منيع الهاشمي بالولاء البصري البغدادي المعروف بابن سعد . 
تحقيق : محمد عبد القادر عطا ـ الناشر دار الكتب العلمية بيروت طا . م)99. - 1 צه - العقائد العضدية تأليف "الإيجي"- عضد الدين عبدالرحمن بن أحمد الإيجي • شرح: الدواني - محمد بن أسعد الصديقي الاواني جلال

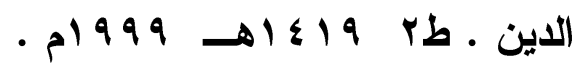

- V تأليف : البوطي - محمد سعيد رمضان البوطي • الناشر دار الفارابي

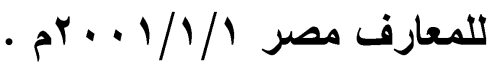
^هـ - على مشارف القرن الخامس عشر الهجري ـ تأليف : إبراهيم ابن علي الوزير . دراسة للسنن الإمهية والمسلم المعاصر تأليف :

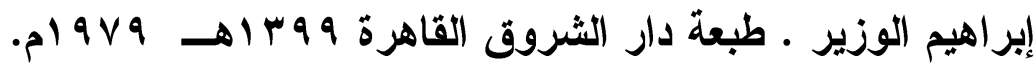
9ه - العواصم و القواصم في الأب عن سنة ابي القاسم ـ تأليف ابن الوزير - محمد بن إبراهيم بن علي بن المرتضى الحسيني القاسمي أبو عبد الله عز الاين من آل الوزير • حققه وضبطه وخرج أحاديثه بن بن بن الثيخ شعيب الأرنؤوط ـ الناشر مؤسسة الرسالة للطباعة والنشر بيزوت - م) • ૧ - غياث الأمم في التياث الظلم ـ تأليف : الجويني - عبد الملك بن عبدالله بن يوسف بن محمد الجويني ـ أبو المعالى ركن الدين الملقب بإمام الحرمين ـ تحقيق عبد العظيم الايب ـ الناشر مكتبة إمام الحرمين . ط آ- فتح القدير تأليف : الشوكاني - محمد بن علي بن محمد بن عبد الله الشوكاني اليمني ـ الناشر دار ابن كثير دمشق طا عـ عـ أهـ. 


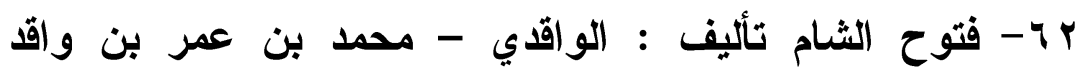

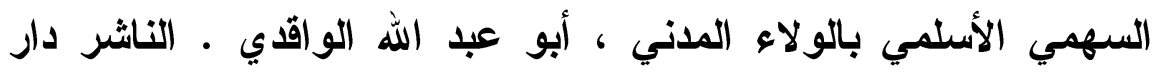

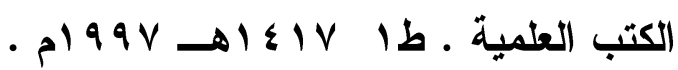
rآ- الفرق الإسلامية تأليف الأستاذ الدكتور مزروعة - محمود

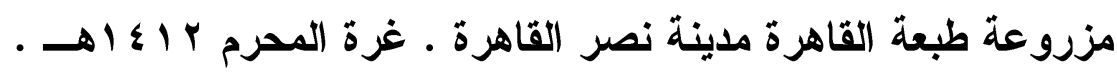

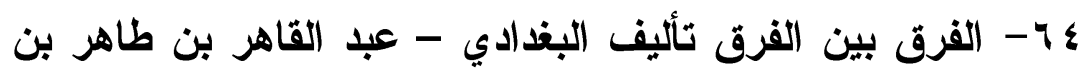

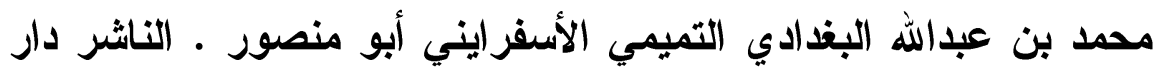

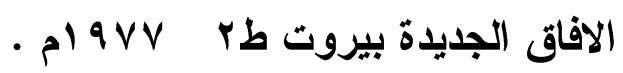

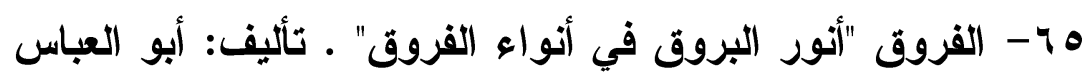

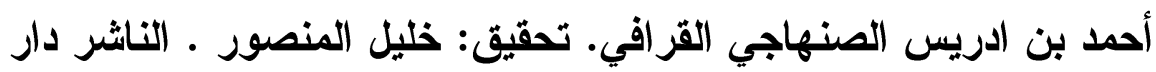

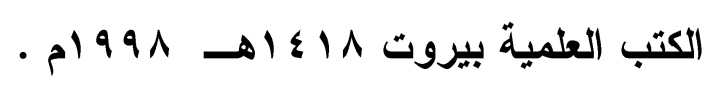

צ

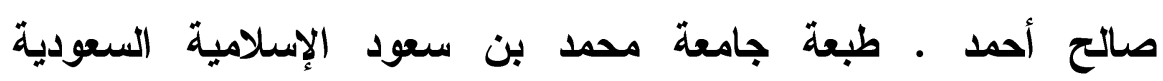

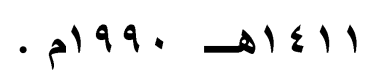

V V - فصل المقال تأليف ابن رشد - الوليد ابن رشد تحقيق الأستاذ

$$
\text { الاكتور محمد عمارة طبعة دار المعارف القاهرة }
$$

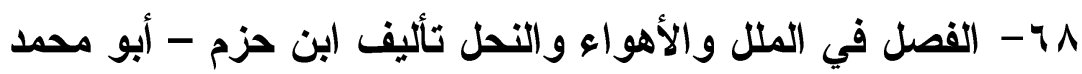

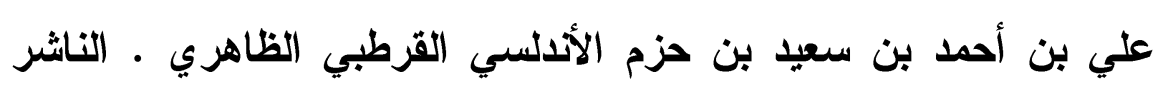

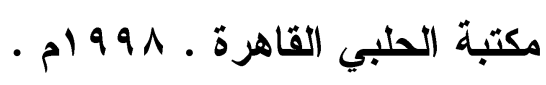

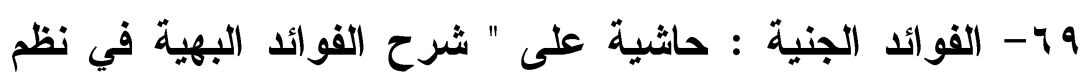

القواعد الفقهية في الأثباه والنظائر على مذهب الثبافية على الثية" ـ تأليف :

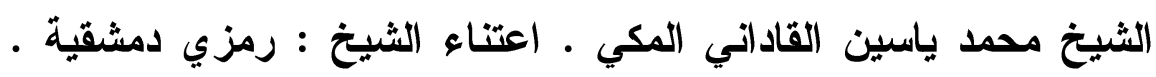

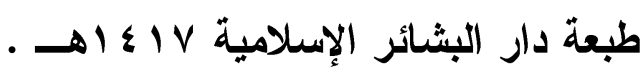


• الطوسي - أبو حامد الغز الي- ضمن مجموعة الجواهر العوالي ، تثتمل على سبعة رسائل إحداها فيصل التفرقة اعتنى بطبعه وتصحيحه وبعض

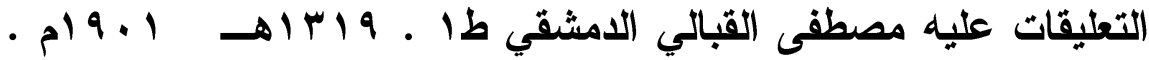

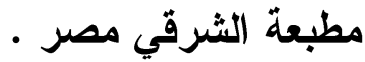

- V الزين الشريف الجرجاني • الناشر دار الكتب العلمية بيروت لبنان طا -

الكثاف عن حقائق غوامض التنزيل "تفسير الزمخثري" -VY تأليف: أبو القاسم محمد بن عمرو بن أحمد الزمخشري جار الله ـ الناشر

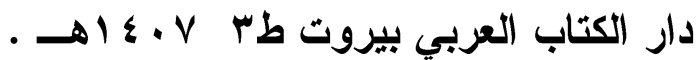
ل لسان العرب ـ تأليف :"ابن منظور" محمد بن مكرم بن علي أبو الفضل جمال الاين أبي منظور الأتصاري الرويفعي الإفريقي ـ الناشر

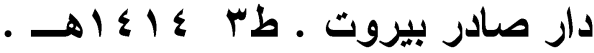
ع - V - لله في نشأة العقيدة للأستاذ عباس محمود العقاد طبعة

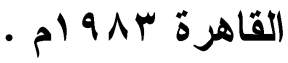

ه - اللؤلؤ والمرجان فيما اتفق عليه الشيخان ـ تأليف : محمد فؤاد عبد الباقي بن صالح بن محمد ـ الناشر دار احياء الكتب العربية ـ محمد الحلبي (بلون طبعة وبلون تاريخ). צV - ما لا يجوز فيه الخلاف بين المسلمين . تأليف : الشيخ

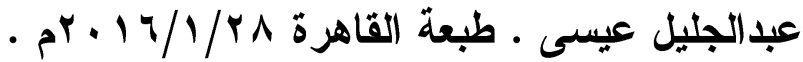
- مV أحمد بن عبدالحليم بن تيمية الحراني ـ تحقيق : عبدالرحمن بن محمد 
بن قاسم . الناشر: مجمع الملك فها لطباعة المصحف الشريف السعودية

$$
\text { . 1990 } 1 \text { (\$) }
$$

- V^ المستدرك على الصحيحين ـ تأليف أبو عبد الله الحاكم محمد م بن عبدالله بن محمد بن حمدية بن نعيم بن الحكم ... النيسابوري .

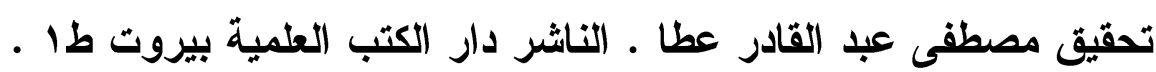

$$
\text { . } 199 \cdot \rightarrow 1 \leqslant 11
$$

- Vq

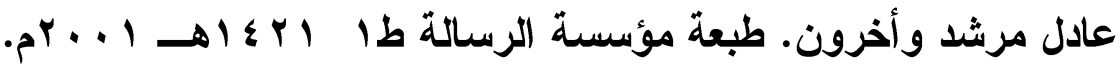

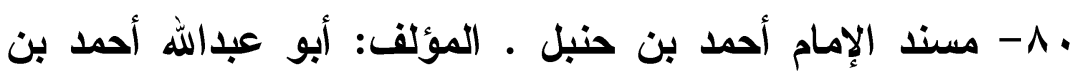
محمد بن حنبل بن هلال الشيباني ـ تحقيق : شعيب الأرنؤوط وأخرون

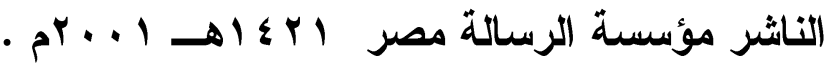
ا - - معارج القدسي في مدارج معرفة النفس تأليف الغزالي - ابو حامد محمد بن محمد الغزالي الطوسي • الناشر دار الافاق الجديدة

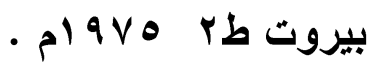
r r - معالم التنزيل في تفسير القرآن "تفسير البغوي" تأليف ـ أبو محمد الحسين بن مسعود بن محمد بن الفراء البغوي الشافعي ـ تحقيق عبد الرازق المهدي • الناشر دار احياء التراث العربي بيروت . طا . $1 \leqslant r$.

rی - معالم التنزيل في تفسير القرآن الكريم "تفسير البغوي" تأليف: محيي السنة - ابو محمد الحسين بن مسعود بن محمد بن الفراء البغوي الثافعي • تحقيث : عبد الرازق المهدي . الناشر دار احياء التراث

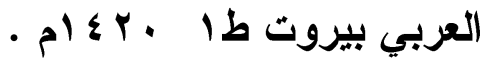


ع 1- معاني القرآن الكريم • تأليف ابو جعفر النحاس تحقيق :

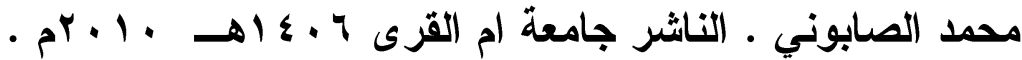
هـ- المغتي لابن قامه ـ تأليف: أبو محمد موفق الاين عبدالله بن احمد بن محمد بن قدامه الجماعيلي المقدسي الامشقي الحنبلي. طبعة

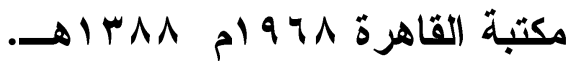

צ 1 - المغني ويليه الشرح الكبير. تأليف: ابن قدامة - عبد الله بن أحمد بن محمد بن قامة المقدي أبو محمد... تحقيق: محمد رشيد

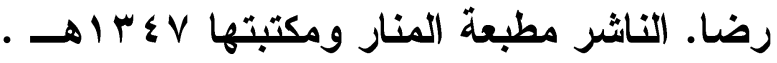
- NV أبو عبد الله محمد بن عمر بن الحسن بن الحسين التيمي الرازي .

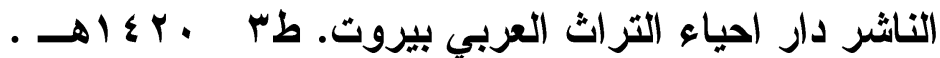
1 1 - مقالات الإسلاميين واختلاف المصليين . تأليف الاشعري أبو الحسن بن بردة بن ابي موسى الاشعري • عني بتصحيحه هلموت ربتر • الناشر دار فرانز بمدينة فبنسادن - المانيا طب . . ع اهـئ - 191 .

9 - مقدمة ابن خلاون تأليف "(بن خلاون" - عبد الرحمن بن محمد بن محمد بن خلاون أبو زيل ، ولي الاين الحضرمي الإثبيلي •

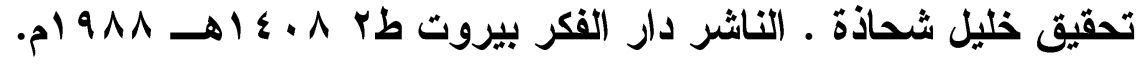
• - المنهاج شرح صحيح مسلم بن الحجاج تأليف "النووي" - أبو زكريا محي الدين بن شرف النووي ـ الناشر دار احياء التراث العربي بيروت . طr rar ا 9- المواقف ـ تأليف الإيجي - عضد الاين عبدالرحمن بن أحمد الإيجي • شرح الجرجاتي - الناشر دار الجيل بيروت طا 99 ام . 
r • - 5) $9 \vee 0$ rq- نظم الارر في تناسب الآيات والسور تأليف: إبراهيم بن عمر بن حسن الرباط ين علي بن ابي بكر البقاعي • الناشر دار الكتاب

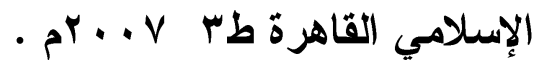
ع - نهاية المحتاج إلى شرح المنهاج ـ تأليف : الرملي - شمس الاين محمد بن ابي العباس أحمد بن حمزة شهاب الدين الرملي ـ الناشر

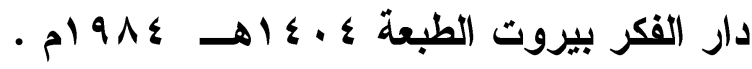
ه - هذا بيان للناس تأليف الشيخ جاد الحق علي جاد الحق طا

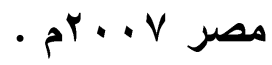
ج 9 - الوجيز في تفسير الكتاب العزيز المؤلف: أبو الحسن علي بن أحمد بن محمد بن علي الواحدي، النيسابوري، الثافعي تحقيق: صفوان عدنان داوودي دار النشر: دار القلم، الدار الثامية - دمشث، بيروت

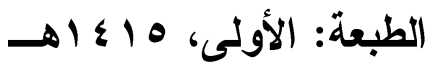


